\title{
WestVirginiaUniversity
}

THE RESEARCH REPOSITORY @ WVU

Graduate Theses, Dissertations, and Problem Reports

2017

\section{Fish, Polychlorinated Biphenyls (PCBs) and Natural Resource Injury}

Daniel W. Sparks

Follow this and additional works at: https://researchrepository.wvu.edu/etd

\section{Recommended Citation}

Sparks, Daniel W., "Fish, Polychlorinated Biphenyls (PCBs) and Natural Resource Injury" (2017). Graduate Theses, Dissertations, and Problem Reports. 6696.

https://researchrepository.wvu.edu/etd/6696

This Dissertation is protected by copyright and/or related rights. It has been brought to you by the The Research Repository @ WVU with permission from the rights-holder(s). You are free to use this Dissertation in any way that is permitted by the copyright and related rights legislation that applies to your use. For other uses you must obtain permission from the rights-holder(s) directly, unless additional rights are indicated by a Creative Commons license in the record and/ or on the work itself. This Dissertation has been accepted for inclusion in WVU Graduate Theses, Dissertations, and Problem Reports collection by an authorized administrator of The Research Repository @ WVU.

For more information, please contact researchrepository@mail.wvu.edu. 
Fish, Polychlorinated Biphenyls (PCBs) and Natural Resource Injury

\author{
Daniel W. Sparks
}

\begin{abstract}
Dissertation submitted to the Davis College of Agriculture, Natural Resources, and Design at West Virginia University
\end{abstract}

in partial fulfillment of the requirements for the degree of

Doctor of Philosophy in

Forest Resource Science

Patricia Mazik, Ph.D., Chair

Kyle Hartman, Ph.D.

Stuart Welsh, Ph.D.

Vicki Blazer, Ph.D., USGS

Scott E. Pruitt, M.S., USFWS

Division of Forestry and Natural Resources

Morgantown, West Virginia

2017

Keywords: Creek Chub, Polychlorinated Biphenyls, PCBs, Reproductive Impairment, Natural Resource Damage Assessment, Injury, Growth, biomass, relative abundance, IBI metrics 


\title{
Abstract \\ Fish, Polychlorinated Biphenyls (PCBs) and Natural Resource Injury
}

\author{
Daniel W. Sparks
}

The Natural Resource Damage Assessment (NRDA) program is authorized by the Comprehensive Environmental Response Compensation and Liability Act (CERCLA) and the Oil Pollution Act (OPA) to pursue compensation for injury to, or destruction and loss of, natural resources. Fish are an important "natural resource" present in almost all aquatic ecosystems. Polychlorinated biphenyls (PCBs) are a hazardous substance and have been shown to cause harm to fish (and fish-eating animals). A series of investigations were conducted to determine if "injury" had occurred to creek chub (Semotilus atromaculatus) and in one study, the fish community that creek chubs were a part of, at several PCB-contaminated study locations. We examined: hepatic condition and oxidative stress enzymes; a comprehensive look at reproductive condition; age and growth; and several metrics of fish community structure and function. Although the determination of hepatic oxidative stress is a response to PCBs, this in and of itself is not considered injury. However, it is a good biomarker of potential injury especially in the presence of other injuries, like reproductive failure. Consistent with the PCB toxicity literature, we consider hepatomegaly and lipidosis injuries that result from PCB exposure. Given that other common factors can also cause lipidosis, this is not an effective injury assessment tool. The age and growth analysis shows significantly reduced survivorship in females at the PCB sites; this is clearly an injury. Aspects of creek chub reproduction have also been adversely impacted: reduced vitellogenin (Vtg), altered sex steroid ratios, reduced fecundity, delayed/ impaired spawning of ova, and reduced / impaired testes maturation. Although not an injury per se, the reduced and seasonally altered pattern of the male secondary sex characteristic nuptial tubercles provides another line of evidence that neuroendocrine disruption is occurring at the PCB-contaminated stream sites. An assessment of the fish community at these PCB-contaminated streams also indicated that growth and survival were issues for the entire fish community. From Frye's standard of evidence [Frye v. United States, 293 F.1013 (D.C. Cir. 1923)], much of this work would have been extremely useful to trustees in court. What we found would be "generally acceptable" in our professional sphere. But scientists and lawyers look at facts differently: same language, same word, different meaning. The science of reproduction impacts is very complicated, and some aspects (i.e. neuroendocrine disruption) while clearly injury, are too complicated to prevail in the courtroom. The impacts to reproduction, including reduced vitellogenin $(\mathrm{Vtg})$, reduced fecundity and delayed/ impaired spawning of ova have significant ecosystem consequences. Growth effects that follow a non-monotonic non-standard dose response curve would do poorly in court. While reduced survivorship should easily be translated to the injury known as "death," nothing in court is certain. Because it is extremely difficult to put a value on natural resources, it is very important to do whatever can be done early on to avoid litigation. A complete win on "injury determinations" (albeit unlikely), could still result in little or no restoration relief. 


\section{ACKNOWLEDGMENTS}

I would like to thank the U.S. Fish and Wildlife Service for the opportunity to enroll in this joint program between the Service's National Conservation Training Center and West Virginia University. This would not have been possible without the support of Scott Pruitt and Lynn Lewis. I would like to gratefully acknowledge my committee, Patricia Mazik, Kyle Hartman, Scott Pruitt, and Stuart Welsh for their instruction and assistance these past many years. I would like to thank John Watkins, Katherine Shortt, Deborah Millsap, Zeeshan Ali, Diane Henshel and Sue Childress for their assistance on Chapter 2. Chapter 3 could not have been accomplished without the assistance of Tom Simon, Joe Exl, Mike Litwin, Mike Tosick, Nancy Denslow and Kevin Kroll. Thanks also to Charles Morris, Will Tucker, Anne Remek and Jim Smith for collaboration and assistance in the lab.

Inspiration to begin this effort came from the many attorneys and long negotiation sessions held over many many years. And special thanks to Cindy my wife for encouraging to finish this. To God be the glory.

The findings and conclusions in this report are those of the author and do not necessarily represent the views of the US Fish and Wildlife Service. Partial funding for this project came from the U.S. Fish and Wildlife Service Environmental Contaminants program and the Department of the Interior Natural Resource Damage Assessment program. 


\section{FOREWORD}

This dissertation is comprised of 6 chapters where chapters $2-6$ have been formatted as manuscripts according to the style of various journals. Chapter 2 is formatted for Archives of Environmental Contamination and Toxicology (AECT). Chapter 3 is formatted for AECT. Chapter 4 is formatted for Ecotoxicology. Chapter 5 has been published in AECT with the following co-authors: Thomas P. Simon and Charles Morris. Chapter 6 is formatted for Environmental Management (Springer). 


\section{TABLE OF CONTENTS}

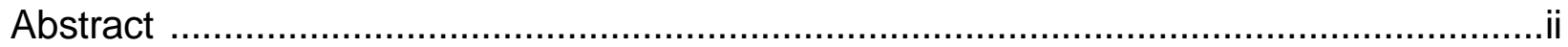

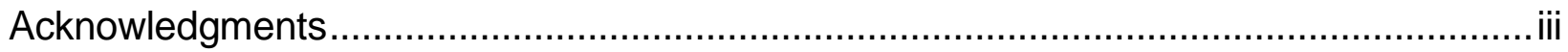

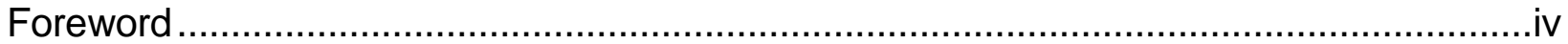

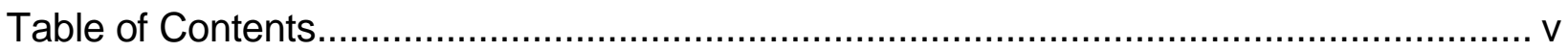

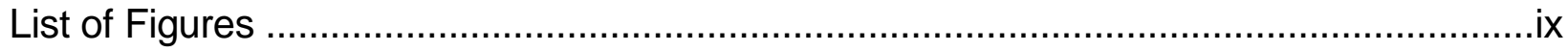

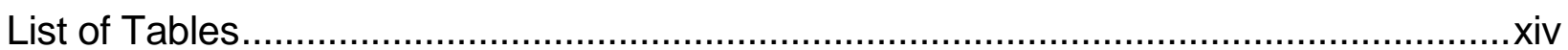

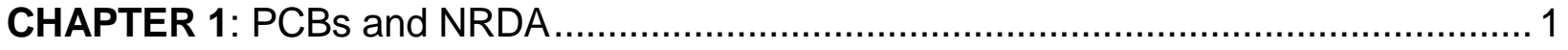

Natural Resource Damage Assessment Primer ................................................ 1

PCBs and Natural Resource Damage Assessment ……................................. 5

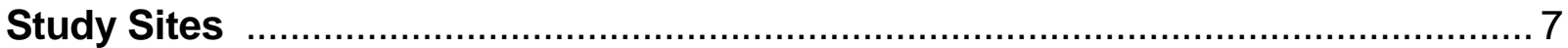

Westinghouse Sites, Monroe County, Indiana .................................................. 7

General Motors, Lawrence County, Indiana .................................................... 12

Little Mississenewa River, Randolph County, Indiana......................................... 12

Elliot Ditch Lafayette, Tippecanoe County, Indiana ........................................... 14

Shelly Ditch, Montgomery County, Indiana ..................................................... 15

References Sites in Monroe and Tippecanoe Counties, Indiana .......................... 17

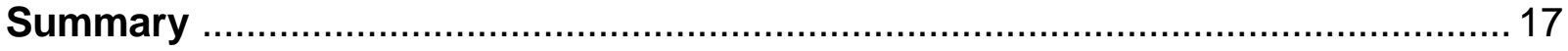

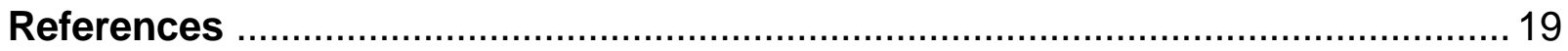

CHAPTER 2: Hepatic oxidative stress and lipidosis in Semotilus atromaculatus from

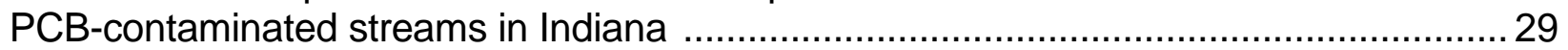

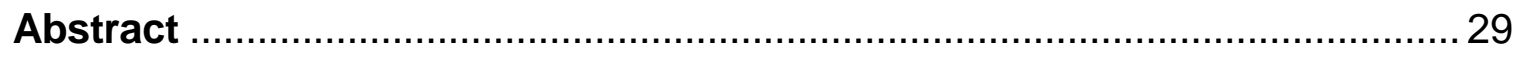

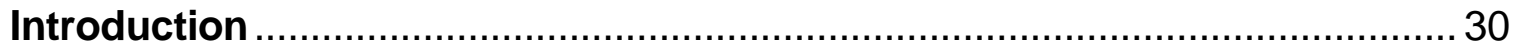

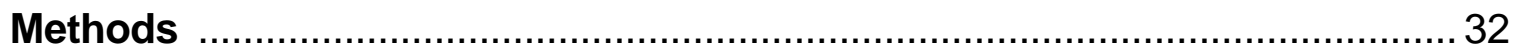

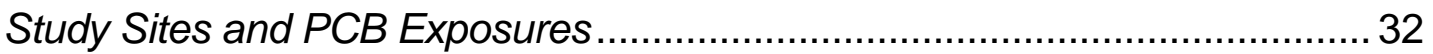

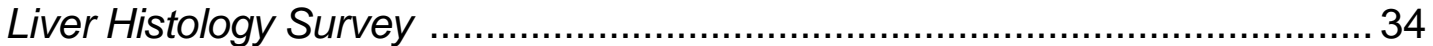

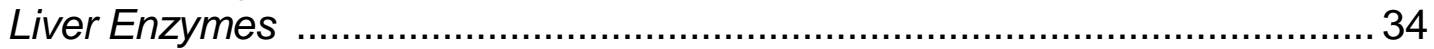


Statistics

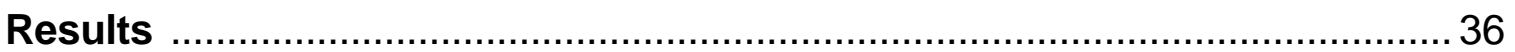

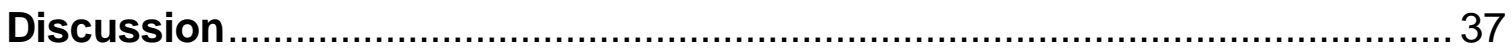

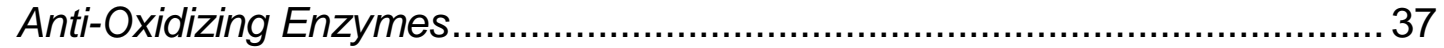

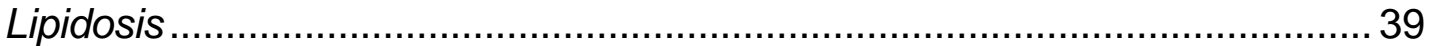

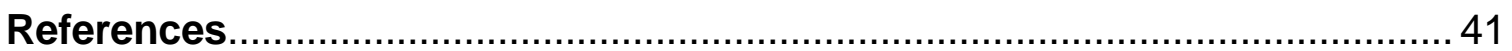

CHAPTER 3: Reproductive biology of creek chub (Semotilus atromaculatus) (Mitchill)

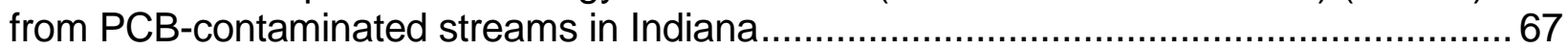

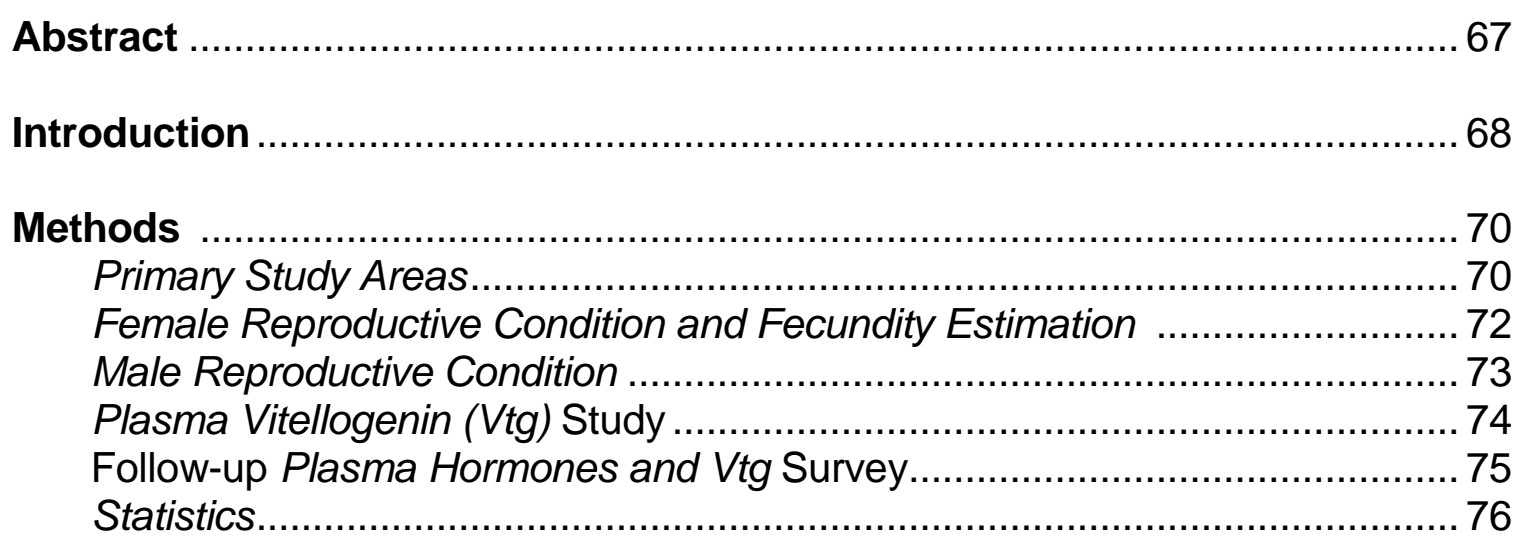

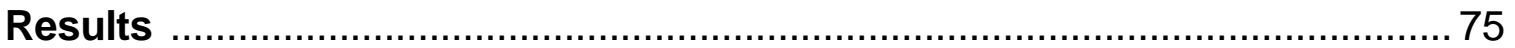

Female Reproductive Condition and Fecundity Estimation ........................ 75

Male Reproductive Condition ................................................................. 77

Plasma Hormones and Vtg Survey ....................................................... 79

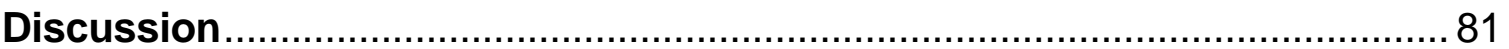

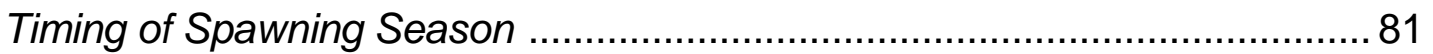

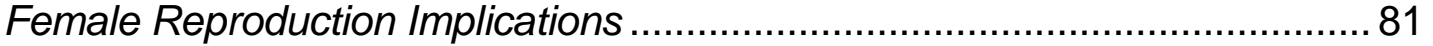

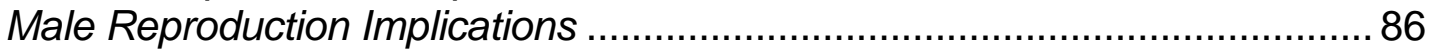

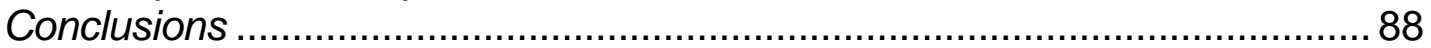

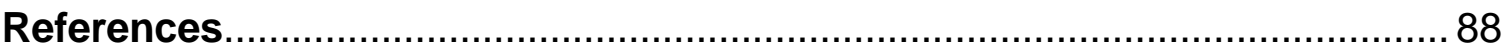

CHAPTER 4: Can age structure alterations and growth impairment of creek chub (Semotilus atromaculatus) in PCB-contaminated streams constitute a Natural Resource Injury? 


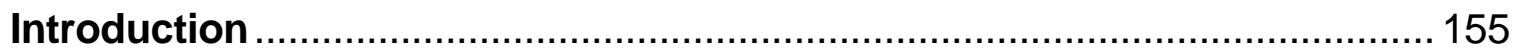

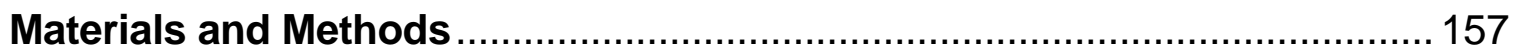

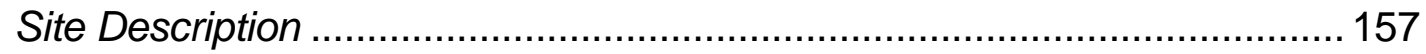

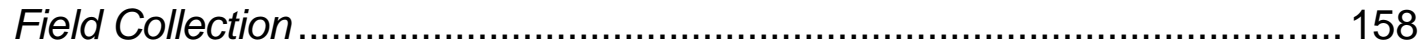

Age and Growth Methodology ........................................................ 158

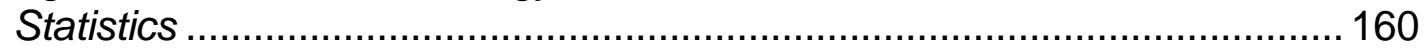

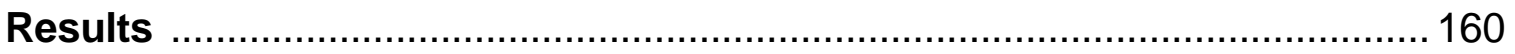

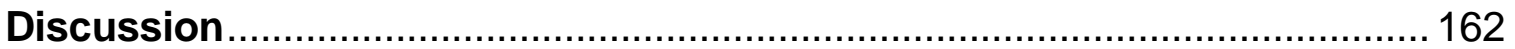

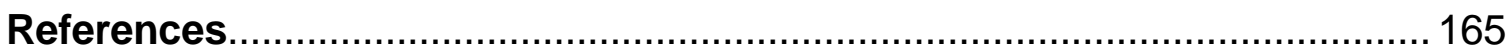

CHAPTER 5: Patterns in stream fish assemblage structure and function

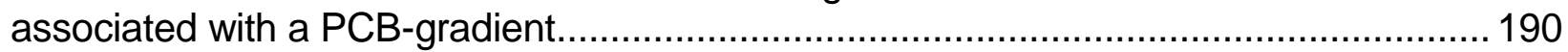

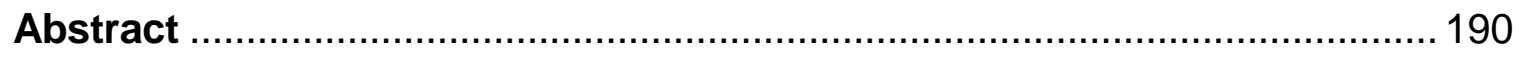

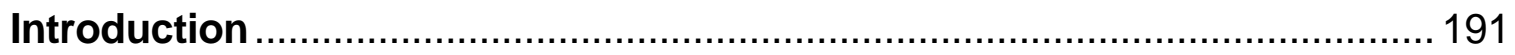

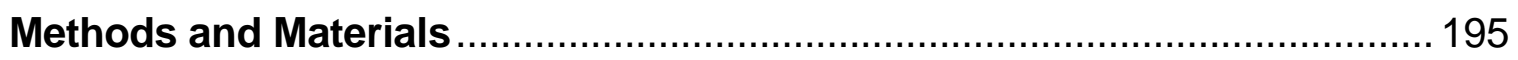

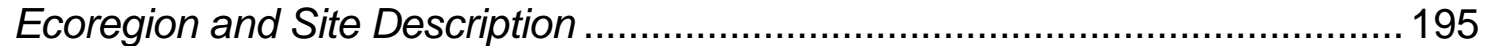

Design and Field Collection ...................................................................... 197

Structure and Function Guild Classification .................................................... 198

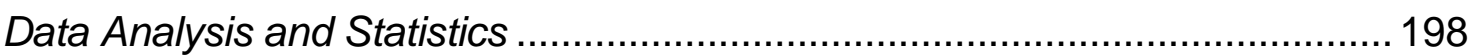

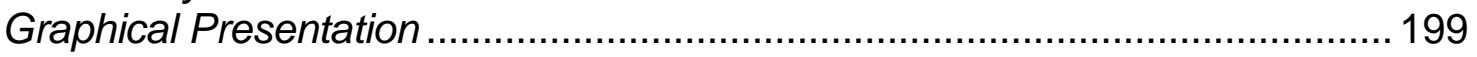

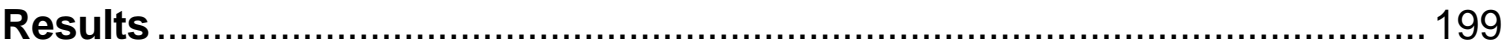

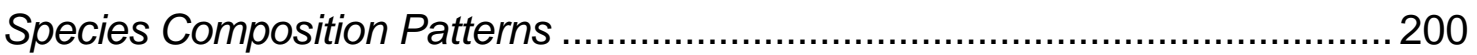

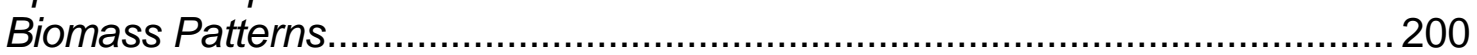

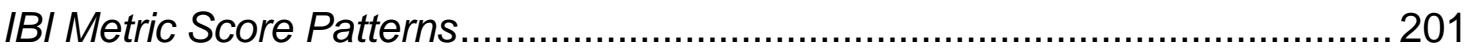

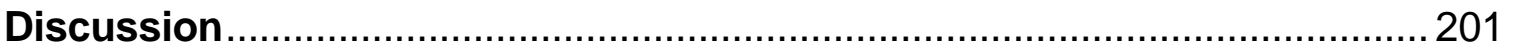

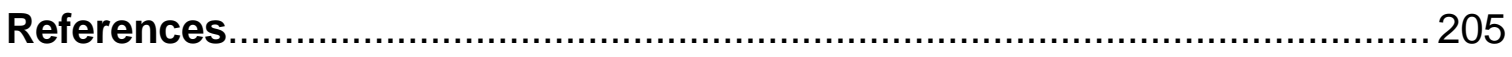

CHAPTER 6: PCBs and Natural Resource injuries to fish at the Westinghouse sites: did we succeed in finding causation?

Introduction 


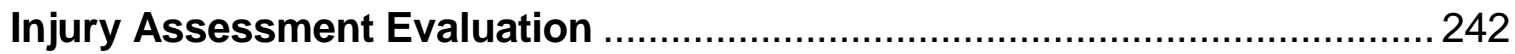

Chapter 1: Water and Fish Tissue PCB Concentrations ................................ 242

Chapter 2: Liver Enzymes and General Liver Health .................................... 245

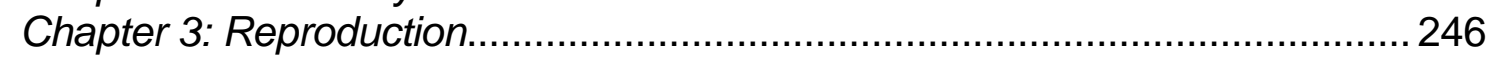

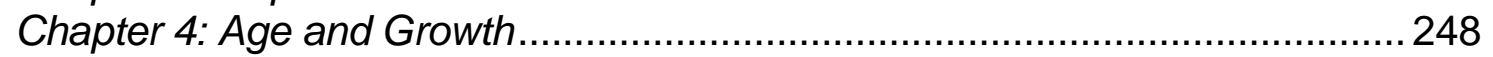

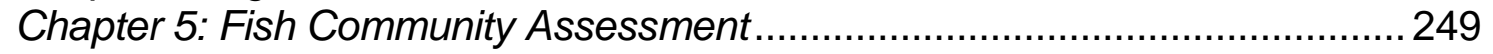

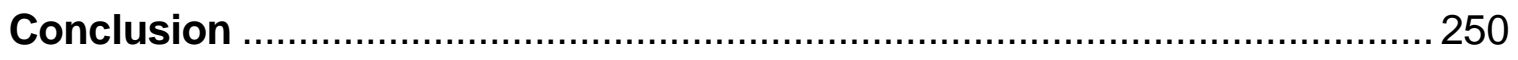

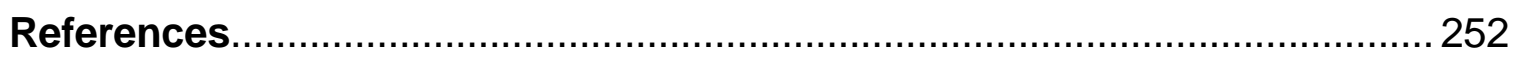




\section{LIST OF FIGURES}

\section{Chapter 1}

Fig. 1. Schematic pathways of PCBs released by Westinghouse to the environment of Monroe and Owen County, Indiana

Fig. 2. Creek chub sampling locations from eight PCB-contaminated streams: upper and lower Clear Creek (ICS and CC), Conards Branch / Richland Creek (CB), Stouts Creek (SC), Sinking Creek (ABB) in Monroe County, Pleasant Run Creek (PR) in Lawrence County, the Little Mississenewa River (LM1 and LM2) in Randolph County, Elliot Ditch / Wea Creek (ED1 and ED2) in Tippecanoe County, and Shelly Ditch (SD) in Montgomery County, Indiana. Also included are two uncontaminated reference sites: Little Indian Creek (LI), and Brummett Creek (BRUM), Greene and Monroe Counties and a slightly elevated background stream, Burnetts Creek (BC) in Tippecanoe County, Indiana

\section{Chapter 2}

Fig. 1. Creek chub sampling locations from eight PCB-contaminated streams: upper and lower Clear Creek (ICS and CC), Conards Branch / Richland Creek (CB), Stouts Creek (SC), Sinking Creek (ABB) in Monroe County, Pleasant Run Creek (PR) in Lawrence County, the Little Mississenewa River (LM1 and LM2) in Randolph County, Elliot Ditch / Wea Creek (ED1 and ED2) in Tippecanoe County, and Shelly Ditch (SD) in Montgomery County, Indiana. Also included are two uncontaminated reference sites: Little Indian Creek (LI), and Brummett Creek (BRUM), Greene and Monroe Counties and a slightly elevated background stream, Burnetts Creek (BC) in Tippecanoe County, Indiana

Fig. 2. Examples of the qualitatively rating scale used to classify the degree of hepatic lipidosis in creek chubs. Reference site fish (LI and BRUM) are mostly on the left, while fish from a high PCB contaminated stream (ICS) are on the right. The qualitative scale was: $1=$ normal, $2=$ moderate, $3=$ high, and $4=$ severe

Fig. 3. Anti-oxidant enzyme activity per unit protein for A) catalase (CAT), B) glutathione peroxidase (GPx), C) glutathione reductase (GRx), and D) superoxide dismutase (SOD) versus degree of stream PCB contamination as grouped in Table 1: reference (Ref), low and / or remediated (LowR), medium (Med), and High. Sample size within bars (error bars $=\mathrm{SD}$ ). Bars with different letters are significantly different (Tukey's test; $\alpha<0.05$ ). 
Fig. 4. Anti-oxidant enzyme activity per unit protein for A) catalase (CAT), B) glutathione peroxidase (GPx), C) glutathione reductase (GRx), and $D$ ) superoxide dismutase (SOD) versus degree of hepatic lipidosis: normal, moderate (mod), high and severe. Sample size is noted within bars (error bars $=\mathrm{SD}$ ). Bars with different letters are significantly different (Tukey's test; $\alpha<0.05$ ).

Fig. 5. Relative frequency and degree of hepatic lipidosis for male and female creek chubs from eight PCB-contaminated streams: upper and lower Clear Creek (ICS and $\mathrm{CC}$ ), Conards Branch / Richland Creek (CB), Stouts Creek (SC), Sinking Creek (ABB) in Monroe County, Pleasant Run Creek (PR) in Lawrence County, the Little Mississenewa River (LM1 and LM2) in Randolph County, Elliot Ditch / Wea Creek (ED1 and ED2) in Tippecanoe County, and Shelly Ditch (SD) in Montgomery County, Indiana. Also included are two uncontaminated reference sites: Little Indian Creek (LI), and Brummett Creek (BRUM), Greene and Monroe Counties and a slightly elevated background stream, Burnetts Creek (BC) in Tippecanoe County, Indiana. Sample sizes are presented in Table 2

\section{Chapter 3}

Fig. 1. Location of the primary study sites in the White River drainage, including: upper and lower Clear Creek (ICS and CC), Conards Branch / Richland Creek (CB) and reference site Little Indian Creek (LI), Indiana

Fig. 2. The 2009 creek chub sampling sites from nine locations on seven PCBcontaminated streams: upper and lower Clear Creek (ICS and CC), Conards Branch I Richland Creek (CB), Stouts Creek (SC), Sinking Creek (ABB) in Monroe County, Pleasant Run Creek (PR) in Lawrence County, the Little Mississenewa River (LM1 and LM2) in Randolph County, and Elliot Ditch / Wea Creek (ED2) in Tippecanoe County, Indiana. Also included are two uncontaminated reference sites: Little Indian Creek (LI), and Brummett Creek (BRUM), Greene and Monroe Counties and a slightly elevated background stream, Burnetts Creek (BC) in Tippecanoe County, Indiana

Fig. 3. Overall female creek chub ovarian condition based on the classification scheme from Heins and Rabito (1986) at: a) the reference site Little Indian Creek (LI), b) upper Clear Creek (ICS), c) Conards Branch / Richland Creek (CB) and d) lower Clear Creek (CC). Mature (MA) ovaries contain mostly phase III ova; Late Maturing (LM) ovaries contain mostly phase II ova; Latent (LA) / Early Maturing (EM) ovaries contain only phase 0 or phase I ova; atretic denotes that the majority of oocytes present are deteriorating. 
Fig. 4. Female creek chub gonadal (ovarian) somatic index (GSI) based on the classification scheme from Heins and Rabito (1986) at: a) the reference site, Little Indian Creek (LI), b) upper Clear Creek (ICS), c) Conards Branch / Richland Creek (CB) and d) lower Clear Creek (CC). Monthly mean GSIs also presented by category of maturation: Mature (MA) ovaries contain mostly phase III ova; Late Maturing (LM) ovaries contain mostly phase II ova; Latent (LA) / Early Maturing (EM) ovaries contain only phase 0 or phase I ova; atretic denotes that the majority of oocytes present are deteriorating; mean equates to overall mean for all females analyzed each month

Fig. 5. Female creek chub mean ova sizes $(\mathrm{mm})$ for each month of the year from the reference site, Little Indian Creek (LI), upper Clear Creek (ICS), Conards Branch / Richland Creek (CB) and lower Clear Creek (CC): a) Phase I ova, b) Phase II ova, and c) Phase III ova. The line and error bars reflect conditions at the reference site, $\mathrm{LI}$......

Fig. 6. Male and female creek chub gonadal somatic index (GSI) at: a) the reference site, Little Indian Creek (LI), b) upper Clear Creek (ICS), c) Conards Branch / Richland Creek (CB) and d) lower Clear Creek (CC)......

Fig. 7. Overall creek chub testes condition (maturation stage) at: a) the reference site, Little Indian Creek (LI), b) upper Clear Creek (ICS), c) Conards Branch / Richland Creek (CB) and d) lower Clear Creek (CC). The visual categories of "immature" was very similar in nature to pre-spermatogenic; "in-between" consistently included earlyand mid-spermatogenic; and "mature" condition essentially equates to late spermatogenic stage. "Blackened" denotes deteriorating testes of an undetermined nature

Fig. 8. Male creek chub gonadal (testes) somatic index (GSI) at: a) the reference site, Little Indian Creek (LI), b) upper Clear Creek (ICS), c) Conards Branch / Richland Creek (CB) and d) lower Clear Creek (CC). Monthly mean GSIs also presented by category of maturation; mean equates to overall mean for all males analyzed each month. The visual categories of "immature" was very similar in nature to prespermatogenic; "in-between" consistently included early- and mid-spermatogenic; and "mature" condition essentially equates to late spermatogenic stage

Fig. 9. Average male creek chub nuptial tubercle score based on the state of testes maturation at: a) the reference site, Little Indian Creek (LI), b) upper Clear Creek (ICS), c) Conards Branch / Richland Creek (CB) and d) lower Clear Creek (CC). The visual categories of "immature" was very similar in nature to pre-spermatogenic; "inbetween" consistently included early- and mid-spermatogenic; and "mature" condition 
essentially equates to late spermatogenic stage. "Blackened" denotes deteriorating testes of an undetermined nature.

Fig. 10. Ratio of testosterone $(T)$ to estradiol $(E)$ in female creek chubs; bars with the same letters are not significantly different $(\alpha=0.05)$. High - high contamination levels; lowR - site has been remediated resulting in significant PCB load reductions; Med - moderately contaminated; and Ref - reference sites

\section{Chapter 4}

Fig. 1. Location of the study sites in the White River drainage, including: upper and lower Clear Creek (ICS and CC), Conards Branch / Richland Creek (CB) and reference site Little Indian Creek (LI), Indiana.

Fig. 2. Creek chub: a) mean male mass (g), b) female mass (g), c) male total length $(\mathrm{TL})(\mathrm{mm})$ and d) female TL (mm) at Little Indian Creek (LI), upper Clear Creek (ICS), Conards Branch and Richland Creek (CB) and lower Clear Creek (CC). Error bars represent $1 \mathrm{SD}$ above the mean. Asterisks denote significant differences from reference site $(\mathrm{LI})$ at $\alpha<0.05$.

Fig. 3. Creek chub relative length frequency comparison for: a) Little Indian Creek (LI) reference site and upper Clear Creek (ICS), b) LI and Conards Branch/ Richland Creek (CB), and C) LI and lower Clear Creek (CC) ....

\section{Chapter 5}

Fig. 1. Location of the study sites in the White River drainage, including: upper and lower Clear Creek (ICS and CC), Conards Branch / Richland Creek (CB) and reference site Little Indian Creek (LI), Indiana

Fig. 2. Significant species composition and relative abundance characteristics of fish assemblage structure along a gradient of PCB-contaminated sites: a) total number of species, b) number of darter, madtom and sculpin (DMS) species, c) number of darter species, d) number of sunfish species, e) number of sucker species, f) number of sensitive species, g) percent individuals as pioneer species and $h$ ) percent individuals as carnivore species

Fig. 3. Significant relative biomass characteristics of fish assemblage structure along a gradient of PCB-contaminated sites: a) total biomass of species, b) biomass of 
sunfish species, c) percent biomass of sunfish species, d) percent biomass of minnow species, e) biomass of sucker species, f) percent biomass of sucker species, g) biomass of sensitive species, h) percent biomass of sensitive species, i) percent biomass of tolerant species, j) percent biomass of pioneer species and k) percent biomass carnivore species.

Fig. 4. Significance of regionally calibrated Index of Biotic Integrity (IBI) metric scores (Simon and Dufour 1998) at a gradient of PCB-contaminated sites: a) percent individuals as headwater species, b) number of minnow species, c) number of sucker species, d) percent individuals as pioneer species, and e) percent individuals as carnivore species. 


\section{LIST OF TABLES}

\section{Chapter 1}

Table 1. Concentrations of PCBs in whole body creek chub samples $(\mu \mathrm{g} / \mathrm{g}$, wet weight) and sediment ( $\mu \mathrm{g} / \mathrm{g}$, dry weight) from eight PCB-contaminated streams: Clear Creek (ICS and CC), Conards Branch / Richland Creek (CB), Stouts Creek (SC), Sinking Creek (ABB) in Monroe County, Pleasant Run Creek (PR) in Lawrence County, the Little Mississenewa River (LM1 and LM2) in Randolph County, Elliot Ditch / Wea Creek (ED1 and ED2) in Tippecanoe County, and Shelly Ditch (SD) in Montgomery County, Indiana. Also included are two uncontaminated reference sites: Little Indian Creek (LI), and Brummett Creek (BRUM), Greene and Monroe Counties and a slightly elevated background stream, Burnetts Creek (BC) in Tippecanoe County, Indiana

\section{Chapter 2}

Table 1. Concentrations of PCBs in whole body creek chub samples $(\mu \mathrm{g} / \mathrm{g}$, wet weight) and sediment ( $\mu \mathrm{g} / \mathrm{g}$, dry weight) from eight PCB-contaminated streams: Clear Creek (ICS and CC), Conards Branch / Richland Creek (CB), Stouts Creek (SC), Sinking Creek (ABB) in Monroe County, Pleasant Run Creek (PR) in Lawrence County, the Little Mississenewa River (LM1 and LM2) in Randolph County, Elliot Ditch / Wea Creek (ED1 and ED2) in Tippecanoe County, and Shelly Ditch (SD) in Montgomery County, Indiana. Also included are two uncontaminated reference sites: Little Indian Creek (LI), and Brummett Creek (BRUM), Greene and Monroe Counties and a slightly elevated background stream, Burnetts Creek (BC) in Tippecanoe County, Indiana

Table 2. Creek chub liver histology samples from eight PCB-contaminated streams: upper and lower Clear Creek (ICS and CC), Conard's Branch / Richland Creek (CB), Stouts Creek (SC), Sinking Creek (ABB) in Monroe County, Pleasant Run Creek (PR) in Lawrence County, the Little Mississenewa River (LM1 and LM2) in Randolph County, Elliot Ditch / Wea Creek (ED1 and ED2) in Tippecanoe County, and Shelly Ditch (SD) in Montgomery County, Indiana. Also included are two uncontaminated reference sites: Little Indian Creek (LI), and Brummett Creek (BRUM), Greene and Monroe Counties and a slightly elevated background stream, Burnetts Creek (BC) in Tippecanoe County, Indiana

Table 3. Mean male hepatic oxidative stress enzymes [ \pm SD, $(N)$ ] in creek chubs from seven PCB-contaminated streams: Clear Creek (ICS and CC), Conards Branch I Richland Creek (CB), Stouts Creek (SC), Sinking Creek (ABB) in Monroe County, Pleasant Run Creek (PR) in Lawrence County, the Little Mississenewa River (LM1 
and LM2) in Randolph County, and Elliot Ditch / Wea Creek (ED2) in Tippecanoe County, Indiana. Also included are two uncontaminated reference sites: Little Indian Creek (LI), and Brummett Creek (BRUM), Greene and Monroe Counties and a slightly elevated background stream, Burnetts Creek (BC) in Tippecanoe County, Indiana

Table 4. Mean female hepatic oxidative stress enzymes [ \pm SD, $(N)$ ] in creek chubs from seven PCB-contaminated streams: Clear Creek (ICS and CC), Conards Branch I Richland Creek (CB), Stouts Creek (SC), Sinking Creek (ABB) in Monroe County, Pleasant Run Creek (PR) in Lawrence County, the Little Mississenewa River (LM1 and LM2) in Randolph County, and Elliot Ditch / Wea Creek (ED2) in Tippecanoe County, Indiana. Also included are two uncontaminated reference sites: Little Indian Creek (LI), and Brummett Creek (BRUM), Greene and Monroe Counties and a slightly elevated background stream, Burnetts Creek (BC) in Tippecanoe County, Indiana

\section{Chapter 3}

Table 1. Concentrations of PCBs in whole body creek chub samples $(\mu \mathrm{g} / \mathrm{g}$, wet weight) and sediment ( $\mu \mathrm{g} / \mathrm{g}$, dry weight) from seven PCB-contaminated streams: Clear Creek (ICS and CC), Conards Branch / Richland Creek (CB), Stouts Creek (SC), Sinking Creek (ABB) in Monroe County, Pleasant Run Creek (PR) in Lawrence County, the Little Mississenewa River (LM1 and LM2) in Randolph County, and Elliot Ditch / Wea Creek (ED2) in Tippecanoe County, Indiana. Also included are two uncontaminated reference sites: Little Indian Creek (LI), and Brummett Creek (BRUM), Greene and Monroe Counties and a slightly elevated background stream, Burnetts Creek (BC) in Tippecanoe County, Indiana

Table 2. Female ovary condition and gonadal somatic index (GSI) for Little Indian Creek (LI) across each month of the year

Table 3. Female ovary condition and gonadal somatic index (GSI) for upper Clear Creek (ICS) across each month of the year....

Table 4. Female ovary condition and gonadal somatic index (GSI) for Conards Branch (CB) across each month of the year

Table 5. Female ovary condition and gonadal somatic index (GSI) for lower Clear Creek (CC) across each month of the year 
Table 6. Average oocyte diameter by stage and age in $\mathrm{mm} \pm \mathrm{SD}(\mathrm{n}=$ number of adult females sampled).

Table 7. Average oocyte diameter by stage and season in $\mathrm{mm} \pm \mathrm{SD}(\mathrm{n}=$ number of adult females sampled)

Table 8. Summary of creek chub fecundity from the literature and including Little Indian Creek, Monroe County, Indiana.

Table 9. Regression equations for creek chub total fecundity versus age in months..... 142

Table 10. Evaluation of histologically determined testes spermatogenic status and gross visual testes condition assessment schemes in comparison to testes gonadal somatic indices (GSI). Site specific means with different letters are significantly different $(\alpha<0.05)$

Table 11. Evaluation of histologically determined testes spermatogenic status and gross visual testes condition assessment schemes in comparison to tubercle status classification. Site specific means with different letters are significantly different $(\alpha<0.05)$

Table 12. Male testes condition and gonadal somatic index (GSI) for Little Indian Creek (LI) across each month of the year

Table 13. Male testes condition and gonadal somatic index (GSI) for upper Clear Creek (ICS) across each month of the year.

Table 14. Male testes condition and gonadal somatic index (GSI) for Conards Branch (CB) across each month of the year.

Table 15. Male testes condition and gonadal somatic index (GSI) for lower Clear Creek (CC) across each month of the year 148

Table 16. Regression equations for male creek chub tubercle score versus testes gonadal somatic index (GSI) 
Table 17. Mean male plasma vitellogenin (Vtg) and sex steroids estrogen (E2) and testosterone $(\mathrm{T})[\mathrm{ng} / \mathrm{ml} \pm \mathrm{SD},(\mathrm{N})]$ in creek chubs from seven PCB-contaminated streams: Clear Creek (ICS and CC), Conards Branch / Richland Creek (CB), Stouts Creek (SC), Sinking Creek (ABB) in Monroe County, Pleasant Run Creek (PR) in Lawrence County, the Little Mississenewa River (LM1 and LM2) in Randolph County, and Elliot Ditch / Wea Creek (ED2) in Tippecanoe County, Indiana. Also included are two uncontaminated reference sites: Little Indian Creek (LI), and Brummett Creek (BRUM), Greene and Monroe Counties and a slightly elevated background stream, Burnetts Creek (BC) in Tippecanoe County, Indiana. Means with different letters are significantly different $(\alpha<0.05)$

Table 18. Mean female plasma vitellogenin (Vtg) and sex steroids estrogen (E2) and testosterone $(\mathrm{T})[\mathrm{ng} / \mathrm{ml} \pm \mathrm{SD},(\mathrm{N})]$ in creek chubs from seven PCB-contaminated streams: Clear Creek (ICS and CC), Conards Branch / Richland Creek (CB), Stouts Creek (SC), Sinking Creek (ABB) in Monroe County, Pleasant Run Creek (PR) in Lawrence County, the Little Mississenewa River (LM1 and LM2) in Randolph County, and Elliot Ditch / Wea Creek (ED2) in Tippecanoe County, Indiana. Also included are two uncontaminated reference sites: Little Indian Creek (LI), and Brummett Creek (BRUM), Greene and Monroe Counties and a slightly elevated background stream, Burnetts Creek (BC) in Tippecanoe County, Indiana. Means with different letters are significantly different $(\alpha<0.05)$

Table 19. Relevant regression equations for creek chub reproduction parameters from the 2009 sampling effort

Table 20. Fish sex steroid ratios [estrogen (E2) and testosterone (T)] taken from the reference site(s) or experimental controls of several literature studies. Ratios presented in ( ) were calculated from data presented in the various studies

\section{Chapter 4}

Table 1. Select physical habitat characteristics, habitat quality, biotic integrity and PCB concentrations (range, means $\pm S D$ ) in various media for three PCB contaminated sites and a reference site in the White River drainage, Indiana

Table 2. Creek chub scale - otolith ${ }^{1}$ age corroboration evaluation 182

Table 3. Creek chub body weight (BW) and total length $(T L)$ differences by sex and site. 
Table 4. Regression equations for creek chub body weight (BW) and total length (LT)

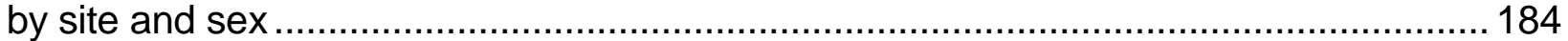

Table 5. Male creek chub mean calculated total length (TL) at successive annuli by

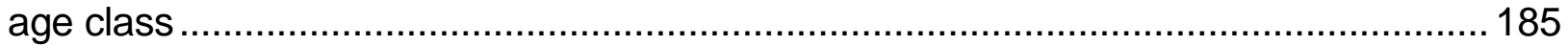

Table 6. Female creek chub mean calculated total length (TL) at successive annuli

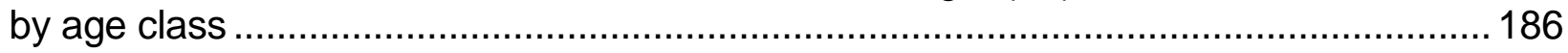

Table 7. Mean male and female instantaneous growth rates by age class

Table 8. Male creek chub weight-length regressions by age class 188

Table 9. Female creek chub weight-length regressions by age class 189

\section{Chapter 5}

Table 1. Select physical habitat characteristics, habitat quality, biotic integrity and PCB concentrations (range, means \pm SD) in various media for three PCB contaminated sites and a reference site in the White River drainage, Indiana.

Table 2. List of 51 structure and function characteristics of fish assemblages (abbreviations in parentheses) that were tested for significance with PCB gradient

Table 3. Fish species collected at the study sites with feeding guild, reproductive guild and tolerance characteristics

Table 4. Kruskal-Wallis Sign by Ranks significance for fish assemblage attributes with PCB concentration for species composition, IBI metric score, and biomass . 234

\section{Chapter 6}

Table 1. Types of Natural Resource injury evaluated and/or observed at the Monroe County, Indiana PCB sites 
CHAPTER 1 - PCBs and NRDA

\section{Natural Resource Damage Assessment Primer}

Congress first legislated the concept of state or federal trustee agencies assessing natural resource damages in §311(f)(5) of the Clean Water Act (33 U.S.C. §1251 et seq.).

"The President, or the authorized representative of any State, shall act on behalf of the public as trustee of the natural resources to recover for the costs of replacing or restoring such resources. Sums recovered shall be used to restore, rehabilitate, or acquire the equivalent of such natural resources by the appropriate agencies of the Federal government, or the State government."

Very little ever came of these provisions because no guidance on how to implement this authority was ever suggested or created. This changed with the passage of the Comprehensive Environmental Response, Compensation and Liability Act (CERCLA) 42 U.S.C. § 9601et seq. (1980). The natural resource damage assessment (NRDA) provisions of CERCLA provides natural resource trustee agencies with the authority to seek compensation for, or restoration of, natural resources which have been injured by discharges of oil and/or releases of hazardous substances. In $\$ 107(a)(4)(C)$ of CERCLA, Congress established that essentially anyone causing:

"a release ... of a hazardous substance, shall be liable for damages for injury to, 
destruction of, or loss of natural resources, including the reasonable costs of assessing such injury, destruction, or loss resulting from such a release...."

Congress also specified that "sums recovered by the United States Government as trustee ... shall be retained by the trustee, without further appropriation, for use only to restore, replace, or acquire the equivalent of such natural resources" [\$107(f)(1) of CERCLA].

The Department of the Interior promulgated NRDA regulations in 1987 (43 C.F.R. 11) as a guide to natural resource trustee agencies for assessing damages for injury to natural resources resulting from the discharge of oil or the releases of hazardous substances. Litigation over these new regulations was initiated State of Ohio v. U.S. Department of the Interior, 880 F.2d 432 (D.C. Cir. 1989) (Ohio v. Interior). Not long afterward, the Oil Pollution Act (OPA) (33 U.S.C. § 2701 et seq.[1990]) was passed (partially in response to the Exxon Valdez spill in Prince William Sound in 1989) specifically addressing and taking primacy over natural resource damage assessments related to discharges of oil from the CERCLA NRDA regulations.

The focus of this dissertation is the "Injury Determination" phase of type B NRDAs. Injury is defined in the NRDA regulations as "a measurable adverse change, either longor short-term, in the chemical or physical quality or the viability of a natural resource resulting either directly or indirectly from exposure to a ... release of a hazardous substance, or exposure to a product of reactions resulting from the ... release of a hazardous substance" (43 CFR 11.14). Natural resource trustees must "determine whether an injury to natural resources has occurred and that the injury resulted from the 
release of a hazardous substance based upon the exposure pathway and the nature of the injury" [43 C.F.R. 11.61 (a)]. Some natural resource injuries are well defined in the NRDA regulations while other categories of injuries are less well defined. For instance, if water samples exceed an established water quality standard for a hazardous substance, then it could be said that the surface water resources (a natural resource) were injured [43 C.F.R. 11.62 (b)(i)]. Or if groundwater resources exceeded a Safe Drinking Water Act standard, then ground water resources would be considered injured [43 C.F.R. 11.62 (c)]. "An injury to a biological resource has resulted from the release of a hazardous substance if the concentration of the substance is sufficient to (i) cause the biological resource or its offspring to have undergone at least one of the following adverse changes in viability: cancer, genetic mutations, physiological malfunctions (including malfunctions in reproduction) or physical deformations; or (ii) exceed action or tolerance levels established under $\$ 402$ of the Food, Drug and Cosmetic Act (21 USC 342) in edible portions of organisms" [43 C.F.R. $11.62(f)(1)]$.

There are acceptance criteria for establishing whether or not water or groundwater or fish tissue exceeds a standard or a tolerance level, and this is fairly straightforward for many hazardous substances. The acceptance criteria for establishing injury to biological resources are as follows [43 C.F.R. $11.62(f)(2)]$ :

(i) the biological response is often the result of exposure to oil or hazardous substances, excluding responses that are caused predominantly by other environmental factors such as disturbance, nutrition, trauma or weather. The 
biological response must be a commonly documented response resulting from exposure to hazardous substances;

(ii) exposure to hazardous substances is known to cause this biological response in free ranging organisms; that it has been documented to occur in natural ecosystems and that the documentation include correlation of the degree of the biological response to the observed exposure concentrations of hazardous substances.

(iii) Exposure to hazardous substances is known to cause this biological response in controlled experiments.

(iv) biological response measurement is practical to perform and produces scientifically valid results.

Biological responses that have been documented only in controlled experimental conditions are insufficient to establish correlation with exposure occurring in a natural ecosystem. In addition, the injury determination must be based on the establishment of a statistically significant difference in the biological response between samples from populations in the assessment area and control area. Determination of appropriate baseline conditions in the control or reference site is important.

Six categories of injury have been evaluated and found to satisfy the acceptance criteria for biological injury. These are: death, disease, behavioral abnormalities, cancer, 
physiological malformations, and physical deformations. Within these categories, there are 18 biological responses that were found to satisfy these injury acceptance criteria.

\section{PCBs and Natural Resource Damage Assessment}

Polychlorinated biphenyls (PCBs) are defined as a hazardous substance in 40 CFR116.A in the Toxic Substances Control Act (TSCA) 15 U.S.C. § 2601 et seq. (1976) so theoretically PCBs could be a good candidate for assessing the both injury criteria and how to evaluate a suite of potential "adverse changes." There are many physical, chemical and toxicological properties of PCBs that lend themselves well to this sort of evaluation. Although many aspects of PCB toxicology have been discovered, it is clear that the state of this science is not fully resolved. Presumably, a rigorously designed scientific investigation could be successful in determining whether or not "a measurable adverse change... in the chemical or physical quality or viability" has occurred in an exposed "natural resource." There are however idiosyncrasies of the NRDA process that also need to be considered in determining whether or not natural resources have been injured. For our purposes, the "natural resource" we evaluate is the creek chub (Semotilus atromaculatus).

The creek chub is an important component of the fish community in many small midwestern streams (Trautman 1981), is widely distributed, occurring in low quality (Katz and Howard 1955) and high quality brooks, creeks, streams, and rivers (USEPA 2010). Katz and Gaufin (1953) observed that creek chubs are the first species back after a pollution event and can tolerate dissolved oxygen (DO) readings under 5 ppm during 
parts of the day. Creek chubs have been observed to rapidly repopulate fish kill zones (Olmsted et al. 1974). Katz and Howard (1955) reported young of year creek chubs did not move significant distances but other studies found creek chubs can move considerable distances. Several studies have shown that creek chubs move a median distance of $50-780 \mathrm{~m}$ between sampling events or seasons (Moshenko and Gee 1973; Storck and Mamot 1981; Belica and Rahel 2008) whereas a small number of individuals were found to travel $1-4 \mathrm{~km}$ when sampling occurred over a larger area (Belica and Rahel 2008; Walker and Adams 2016).

Creek chubs are present at and downstream at all of the study sites described below. These sites reflect the range of complexity of hazardous waste sites containing and releasing PCBs to the environment that the Indiana Department of Environmental Management (IDEM) and U.S. Environmental Protection Agency (U.S. EPA) contend with under CERCLA and other clean-up authorities. While individual creek chubs will move up and downstream from our study areas, studying populations of creek chubs over many seasons will capture the essence of what the fish community is subjected to in these areas. Generally speaking, fish represent conditions in and near where they are sampled. There is variability in exposures based on food, and time spent in various microhabitats but this is also integrated over time. Long distant movements by individuals complicate interpretations however, the vast majority of creek chubs are not constantly migrating. Our headwater study areas have historically had the most significant inputs of PCBs (typically water column inputs) that quickly translocate to sediment where PCBs reside over the long term. Although there is always flux between water, sediment and air, and potentially sediment transport downstream, creek chubs offer a good example of what 
local exposures consist of. It is likely that at some of our study sites, there is a higher potential for large fish from non PCB-contaminated habitats to be recent immigrants to the area and included in those samples. There are also tributaries that are relatively free of PCBs that are not that far from some of our study sites that may also contribute to our samples. Although there are likely several small impediments to easy migration (culverts), it is possible that creek chubs could be from other sites despite the fact that our two closest same stream study areas are $2 \mathrm{~km}$ apart. The value of sampling many fish over all months of the year is that the general condition of the creek chub population is represented.

\section{Study Sites}

Westinghouse Sites, Monroe County, Indiana PCB sites

In 1958 Westinghouse Corporation opened a factory in Bloomington, Indiana and began manufacturing electrical capacitors. In this manufacturing process, capacitors were filled with an insulating fluid called Inerteen which consisted primarily of polychlorinated biphenyls (PCBs). Westinghouse purchased PCBs from Monsanto, the sole U. S. manufacturer of PCBs. Available production data for the period 1966 -1972 (Kacir 1983) indicates that 7.2 million $\mathrm{kg}$ of Inerteen were used to manufacture 461,256 capacitors. Kacir (1983) also indicated that from 1966 to 1971 (and probably from the beginning of plant operations to 1971), Aroclor 1242 was used to fill capacitors. Aroclor 1016 replaced Aroclor 1242 in the fall of 1971, and it was used through at least May 1972 (and likely until 1977 when the usage of all PCBs came to an end). At these production rates, it is 
estimated that as much as 22.7 million $\mathrm{kg}$ of PCBs were handled by this plant over its 20 year usage of PCBs.

Most of the PCBs were sent to Westinghouse customers all over the country in sealed capacitors. It is estimated that at least $90 \%$ of the capacitors manufactured were shipped to customers. The larger capacitors were filled, placed into high vacuum ovens, topped off with PCBs, and the lid soldered on. They were then sent to the can washing line (which included the use of solvents, soap and acids) (Westinghouse 1971). Capacitors were tested for operational competence and in the early years of manufacturing at this plant, capacitors that failed were hauled away. Available data indicates that 5 to 10 percent of capacitors manufactured were scrapped due to defects or overproduction. Some capacitors were partially drained of Inerteen prior to disposal. Prior to 1970, none of the small capacitors and only less than half of the large capacitors were drained. After 1970, all capacitors were drained prior to disposal (Kacir 1983). It has been suggested that spills inside the plant were cleaned up with sawdust (Westinghouse 1971) and other materials, such as clay, were sometimes used to purify Inerteen (Kacir 1983). These materials were disposed of at local landfills. Fig. 1 shows the migration pathways of PCBs from the Westinghouse plant into the surrounding environment. PCBs were spilled onto the plant property during transportation, handling, and capacitor production, including a significant spill from a leaking rail car in the early 1970 s. Approximately 22,675 metric tons of PCB-contaminated soil were removed from the former Westinghouse plant in 1994. The concrete floor of the former manufacturing facility and the soil underneath contained very high concentrations of PCBs, as high as 20,000 
ppm. A total of 36,280 metric tons of contaminated soil and 3,628 metric tons of contaminated concrete were removed from the site in late 2009.

Inerteen entered the sanitary sewer leading to the City of Bloomington's wastewater treatment plant (Winston Thomas) through standard washing procedures as well as through spills to the floor drains prior to 1971. In the early 1970s, Westinghouse estimated the magnitude of these discharges to Winston Thomas to be $11.3 \mathrm{~kg}$ of PCBs per day (Munson 1971). After the city was notified of these discharges in 1975, PCB discharges to Winston Thomas continued but were reduced as best management practices were continued and the company diverted their waste water discharge to Sinking Creek under an individual NPDES permit from the mid-1970s to the mid-1990s. There was a history of non-compliance with the PCB discharge limits of this permit and the remedial actions taken at the site in 1994 left ecologically relevant concentrations of PCBs in nearby surface waters and wetlands that still remain. In 2004 and 2009, we sampled creek chubs in Sinking Creek (ABB) approximately $1.8 \mathrm{~km}$ south of the manufacturing plant.

Winston Thomas wastewater treatment plant received PCB discharges from Westinghouse from 1958 through 1982, when it ceased operations. Virtually all components of Winston Thomas were contaminated with PCBs. Based on PCB concentrations taken from the "main" sewer in 1976, $2.4 \mathrm{~kg}$ PCBs per day were still entering the plant via the "main" sewer more than 10 years after Westinghouse's discharges ceased to use that sewer line (Powell 1996).

Several pathways existed for PCBs to leave Winston Thomas, but the primary route was the discharge of treatment effluent containing PCBs to Clear Creek. In 1976, it 
was estimated that more than $1 \mathrm{~kg}$ of PCBs per day were discharged to Clear Creek. Composted sewage sludge, contaminated with several thousand parts per million of PCBs, was disposed of by giving away as fertilizer to home owners, used to fill sinkholes on-site, and placed as fill in the floodplain of Clear Creek in at least two very large areas (Brophy 1995).

As previously mentioned, other waste materials from the Westinghouse capacity factory were hauled to local landfills. The Anderson Road Landfill accepted waste and capacitors from Westinghouse in the late 1960s and early 1970s. In the 1980s, the PCBcontaminated material (approximately 4,535 metric tons) was removed from the Anderson Road landfill and shipped to a licensed hazardous waste landfill.

Bennett's Quarry Dump (BD) was used for dumping and scavenging of capacitors manufactured by Westinghouse after 1966. In 1983, 252 visible capacitors were removed from the site as part of interim remedial measures. In 1999, 32,808 metric tons of PCBcontaminated materials and 1,756 capacitors were removed from this site. Final treatment options were implemented in August 2009 to reduce contaminated groundwater discharges to Stouts Creek (SC) and were completed in 2011. We sampled creek chubs in SC $2.2 \mathrm{~km}$ downstream of BD regularly 2003-2004 and 2009.

Neal's Landfill (NL) accepted undrained and partially drained capacitors and other solid waste from the Westinghouse plant during 1966 and 1967. Visible capacitors and surface contamination were removed during interim remedial measures in 1987 and the site was capped. A small water treatment plant came on-line in 1990 to treat some of the PCB-contaminated groundwater that discharges from several springs near this site. In 1999, 37,864 metric tons of PCB contaminated materials and 4,119 capacitors were 
removed from this site. Final treatment options removed contaminated sediment and improved treatment of groundwater discharges to Conards Branch. These final measures were completed in 2011. We sampled creek chubs in Conards Creek/Richland Creek (CB) 0.8 km downstream of NL regularly in 1999-2001, 2004-2005 and 2009.

Lemon Lane Landfill (LL) accepted undrained and partially drained capacitors and other PCB-contaminated solid waste from the Westinghouse plant from 1958 to 1964. Records of waste disposal and landfill operations are not available, but it appears that this was the only disposal facility used by Westinghouse during this time period. In 1987 , Westinghouse removed 404 exposed capacitors from the landfill surface, and the site was capped. In 2000 , the U.S. EPA built a 3,785 L per minute water treatment plant in order to capture and treat PCB-contaminated groundwater that discharges from springs associated with LL. Currently, non-storm flows at Illinois Central/ Quarry Springs (ICS) carry approximately $1.8 \mathrm{~kg}$ of PCBs per year to Clear Creek. Storm flows carry approximately $2.7 \mathrm{~kg}$ PCBs per year, for a total of approximately $4.5 \mathrm{~kg}$ PCBs per year. Also in 2000 , Westinghouse began the removal of 72,639 metric tons of contaminated material and 4,402 capacitors from this site. Final remedial actions included upgrades to water treatment plant capacity and additional soil removal near the groundwater spring discharge points. These actions were completed in 2010. We sampled creek chubs in the ICS branch of Clear Creek (ICS) 2.0 and $4.0 \mathrm{~km}$ (CC) downstream of LL regularly in 1999-2001, 2004-2005 and 2009.

Some Westinghouse capacitors were taken to Fell Iron and Metal, a salvage yard in downtown Bloomington. They may have been taken there directly or after initial disposal at local dumps. Many capacitors and 24,489 metric tons of PCB-contaminated 
soil were removed from the Fell Iron and Metal site during the early 1990s. This site may have historically contributed a small amount of PCBs to the downstream CC site.

General Motors, Lawrence County, Indiana

The General Motors (GM) Bedford plant is located in the headwaters of Pleasant Run Creek (PR) in Lawrence County, Indiana. From 1965 to the mid-1970s, PCBs were used in hydraulic fluids at this aluminum casting foundry. Used hydraulic fluids were disposed of into on-site lagoons that contaminated the ground and nearby surface waters. GM also maintained some aspects of water treatment but this did not prevent the direct downstream release of PCBs to PR. Pleasant Run Creek flows north and enters Salt Creek approximately $16.9 \mathrm{~km}$ downstream of its confluence with Clear Creek. In 2001 near the GM foundry, fish from PR contained up to 1,698 ppm PCBs (Exponent 2002). It is likely that these fish had been exposed directly to waste hydraulic oil that was seeping into the stream through fractures in the bedrock. These are the highest PCB concentrations ever reported in Indiana. Whole body creek chubs at our frequent sampling location (PR), approximately $1.1 \mathrm{~km}$ downstream from the GM foundry, contained $359 \mu \mathrm{g} / \mathrm{g}$ PCBs in 2001. Remediation at this facility began in approximately 2004 and continued until GM filed for bankruptcy in February 2009. We sampled creek chubs at PR regularly in 2001, 2003-2004 and 2009.

Little Mississenewa River, Randolph County, Indiana

Two manufacturing facilities located in Union City, Indiana discharged significant quantities of PCBs to the Little Mississenewa River (LMR) prior to 1990 (U.S. EPA 2004). 
Sheller-Globe, a subsidiary of United Technologies Automotive Systems, Inc. (UTA), was an electroplating and die-casting facility that manufactured small automotive parts. The facility closed its operations in 1990 (UTA 1994a). Historically, wastewater treatment consisted of drain lines to an unlined concrete impoundment $(3.7 \mathrm{~m}$ by $6.1 \mathrm{~m}$ and $2.1 \mathrm{~m}$ deep) located just east of LMR (IDEM 1989). Investigations at this facility indicated that spills had occurred in the drum storage area which contained drums of waste oil, hydraulic fluid, and solvents. It was determined that both groundwater and the sewer lines to the wastewater impoundment were contaminated with PCBs (Aroclor 1248) (IDEM 1989). Concern for PCBs in UTA's NPDES discharges to LMR were raised in 1987 (U.S. FWS 1987). Sediment sampling in LMR in 1997 near its discharge found high levels of PCBs in sediments (up to 3,000 ppm) (Sciences International Inc. 1998). In 1994, UTA's groundwater treatment system discharged a maximum of $7.52 \mu \mathrm{g} / \mathrm{L}(0.1 \mathrm{~g} /$ day $)$ of PCBs (UTA 1994b).

Just across LMR to the west, Westinghouse manufactured small motors at its 13.8 ha facility in Union City, Indiana from 1950 to 1986 (IDEM 1994). A leaking underground storage tank containing xylene was removed in 1985. Waste management at this facility consisted of an oil skimmer basin, on-site burning and disposal (IDEM 1990a). Metal shavings, solvents, paint, paint waste and oils (including hydraulic, cutting and lubricating) were buried on site. The skimmer basin discharged directly to the LMR. In 1986, high concentrations of PCBs were discovered in the die-casting machine area of the plant, the discharge line and skimmer basin (IDEM 1990a). Remedial efforts in 1986 included cleaning the die-casting machine area of the plant and the discharge line to the skimmer basin. The extent of trenching and waste disposal areas were determined and several 
shallow groundwater wells were installed, including the xylene contaminated area (IDEM 1990a). The contents of the skimmer basin were pumped onto adjacent on-site soils. Also in 1986, it was discovered that Union City's wastewater treatment plant was contaminated with PCBs (IDEM 1990a). The lift station and sewer lines near Westinghouse were found to contain PCBs and these were cleaned that same year (IDEM 1990a). In 1990, IDEM determined that the majority of the 13.8 ha site was contaminated with low level PCBs (Aroclors 1248, 1254 and 1216) (IDEM 1994). In addition, it was determined that groundwater at the site contained high levels of xylene, and PCBs. Sediments also contained high levels of PCBs at and downstream of where the skimmer discharges entered LMR (83 - 690 ppm) (IDEM 1994).

After a series of small removal actions and voluntary remedial efforts, including sediment removal from $37 \mathrm{~m}$ of LMR in the plant outfall area in 1999, the U.S. EPA embarked on an expedited Superfund remedial assessment and cleanup in 2001 of PCBs in the remaining reaches of LMR (U.S. EPA 2004). Between 2004 and 2007, many PCB hotspots were removed or capped throughout the approximately $12.1 \mathrm{~km}$ of the LMR. We sampled creek chubs in the UTA / Westinghouse outfall area (LM1) and $6.3 \mathrm{~km}$ downstream (LM2) on the LMR regularly in 2001, 2003-2004, and 2009.

Elliot Ditch, Lafayette, Tippecanoe County, Indiana

Alcoa Inc. has a fabricated aluminum products manufacturing facility located on 71.7 ha in the headwaters of Elliot Ditch (ED) in Lafayette, Indiana. This facility used PCBs until they were banned in 1972 and PCBs were first identified in fish downstream of the facility in 1979. In addition to PCBs, Alcoa discharges approximately 5.75 million $L$ of wastewater 
per day to ED which has a modeled 7Q10 flow rate of $0 \mathrm{~m}^{3} / \mathrm{s}$ (IDEM 1990b). Alcoa's NPDES permit also regulates $\mathrm{Zn}, \mathrm{Cr}, \mathrm{Al}, \mathrm{Cu}$, cyanide, oil and grease. Several voluntary actions have been taken at this facility in the 1980s to reduce the release of PCBs (Brauner 2001), however, ED remains highly contaminated with PCBs (U.S. EPA 2011). In addition this stream has additional contamination including metals, and polycyclic aromatic hydrocarbons (PAHs). We sampled creek chubs $1.8 \mathrm{~km}$ (ED1) and $5.7 \mathrm{~km}$ downstream (ED2) of Alcoa's outfall on ED regularly in 2001, 2003-2004, and 2009.

\section{Shelly Ditch, Montgomery County, Indiana}

The Raybestos facility in Crawfordsville, Indiana, began manufacturing automatic transmission friction plates in 1951. According to Raybestos, they used a Monsantomanufactured lubricating oil containing $67 \%$ PCBs, as a hydraulic fluid for a 6-month period In the 1960s. From this time forward, PCB lubricating oil was released to surface soils, sewer lines and underground piping at the facility. An unknown quantity of PCBs migrated via storm water drainage outfalls located on the west side of the facility into Shelly Ditch (SD). The SD site was initially discovered in November 1995, when IDEM was investigating a neighboring facility (U.S. EPA 2001). A background (upstream) sediment sample was collected in SD adjacent to the Crawfordsville Scrap \& Salvage site which contained 410 ppm PCBs (Aroclor 1248) and 2,300 ppm lead (U.S. EPA 2001). Additional sampling in 1996 revealed high concentrations of PCBs in both shallow and deep $(0.9 \mathrm{~m})$ sediments within SD and the floodplain. One surficial sediment sample contained 22,600 ppm PCBs. From 1997 to 1999, Raybestos and IDEM negotiated a possible cleanup of SD (U.S. EPA 2001). 
In spring 1999, Raybestos permanently plugged a 0.45 m diameter culvert on the west side of the property and removed contaminated soil from this area. This was thought to be a key source of PCB contamination from the plant to SD. Further cooperation on site cleanup between Raybestos and IDEM broke down in fall 1999. In December 1999, IDEM ordered Raybestos to: immediately cease discharging water contaminated with PCBs, submit a plan to eliminate all illegal discharges, implement the approved plan, and pay a civil penalty (U.S. EPA 2001).

In May 2000 IDEM requested U.S. EPA's assistance with cleanup activities regarding SD. U.S. EPA conducted a Site Assessment of the Shelly Ditch Site in May 2000 , and concluded that a substantial threat to human health and the environment did exist. On December 6, 2000, U.S. EPA issued a Unilateral Administrative Order (UAO) under CERCLA 106 authority, to Raybestos which required them to perform a time-critical removal action. The cleanup levels were $10 \mathrm{ppm}$ for total PCBs and $400 \mathrm{ppm}$ for total lead. Sediment and soil removal was limited to the $1.0 \mathrm{~km}$ stretch of SD (divided into 3 reaches) between the Raybestos outfalls downstream to Whitlock Street. Excavation and restoration work in Reach 1 was completed in July 2002 (U.S. EPA 2003), and included the removal of access roads and almost all of the trees. Reconstruction consisted of compacted clay and crushed stone and geotextile / geomembrane materials to backfill and cap the ditch bed. Rip rap was placed on the side slopes and flagstone has been placed in the ditch (U.S. EPA 2003). After final grading, the area was seeded and irrigated. Reaches 2 and 3 were remediated and restored in 2003 (U.S. EPA 2003). Reconstruction in these areas was similar to reach 1, but included $25 \mathrm{~cm}$ of concrete lining the ditch bed, and 3 concrete drop structures to compensate for 
elevation changes in the stream (U.S. EPA 2003). We sampled creek chubs $0.8 \mathrm{~km}$ (SD) further downstream of the remediated stretch of SD regularly in 2001 and 2003-2004.

Reference Sites in Monroe and Tippecanoe Counties, Indiana Little Indian Creek (LI), located in southwestern Monroe County, Indiana served as our primary reference site sampling creek chubs regularly from 1999 through 2009. However, in 2008 it was clear that this stream was experiencing a significant increase in eutrophication. The LI watershed consists primarily of a mix of forest and small farms, but in the late 2000s, there was a steady increase in the number of confined cattle feeding operations.

Brummett Creek (BRUM) is a small stream located in northeastern Monroe County, Indiana. It originates in Yellowwood State Forest and flows into Monroe Reservoir. We began to utilize BRUM as a reference site in 2008 primarily for the liver histology and liver enzyme work in Chapter 2 and for vitellogenin and hormone assays in Chapter 3 because we were uncertain if LI would remain a suitable reference for these studies. We also added Burnett Creek (BC) as a reference site in 2001. Our BC sample site is located in the small town of Battle Ground, Tippecanoe County, Indiana. This small urban watershed is similar to the $\mathrm{CC}$ sites in many respects. All of the study sites are identified on Fig. 2.

\section{Summary}

There is no case law established for PCBs and natural resource injuries. There have 
been many of scientific investigations on the toxicology of PCBs and several may be conformed to the NRDA regulations. Specific guidelines for natural resource trustee agencies are sorely lacking in this area. The two "defacto" injury conditions that PCBs can often trigger, the exceedance of either an established water quality criteria or a fish consumption advisory, are not often afforded the credibility they deserve. In this study, we focused on several injuries that are accepted by the regulations in two broad categories: physical deformations [43 CFR $§ 11.62(f)(4)(v i)]$, and physiological malfunctions [43 CFR $\S 11.62$ (f)(4)(v). Physical deformations include: internal whole organ and soft tissue malformation (C), and histological lesions (D) (Chapter 2). Physiological malfunctions is focused on reduced fish reproduction (E) (Chapter 3). We also evaluated the concept of growth and survivorship (Chapter 4) and fish community assessment (Chapter 5) using the "acceptance criteria" [43 C.F.R. $11.62(f)(2)]$ as an additional category of potential natural resource injury. There are many interesting aspects of bringing complex scientific investigations into the courtroom. Toxic torts, or civil cases involving medical or environmental harm are uniquely difficult to litigate successfully. Courtroom rules of evidence and judicial discretion as to what is admissible and what is not varies greatly from court to court despite some developed case law [i.e. Daubert v. Merrell Dow Pharmaceuticals, Inc., 113 S. Ct.2786 (1993) and prior to that, Frye v. United States, 293 F.1013 (D.C. Cir. 1923)]. How the science of PCBs and these fish specific injuries might succeed in the legal arena are discussed in Chapter 6. 


\section{References}

Belica LAT, Rahel FJ (2008) Movements of creek chubs, Semotilus atromaculatus, among habitat patches in a plains stream. Ecol Freshw Fish 17:258-272

Brauner D (2001) Elliot Ditch / Wea Creek sediment site preliminary ecological risk assessment. U.S. Environmental Protection Agency, Region V, Chicago, IL. 34 pp

Brophy E (1995) Letter report regarding a partial construction history and maintenance of the Winston Thomas wastewater treatment plant. City of Bloomington Utilities, Bloomington, Indiana

Exponent (2002) Bedford RFI Technical Memorandum 12001 Stream Investigation Data Summary. GM Powertrain - Bedford Plant, 105 GM Drive, Bedford, Indiana EPA ID\# IND006036099. Prepared for General Motors Corporation. 108 pp

Indiana Department of Environmental Management (IDEM) (1989) RCRA facility assessment PR/VSI report and CERCLA preliminary assessment report for Sheller-Globe Corporation Union City Plant, Union City, Randolph County, Indiana. Expanded site investigation for Sheller-Globe, Union City, Indiana. U.S. EPA ID: IND006066377, March 9, 1989. Site Investigation Section, IDEM, Indianapolis, IN

IDEM (1990a) Preliminary Assessment and executive summary A.O. Smith Electric Motor 
Co. EPA ID\# IND000819904, Union City, Randolph County, Indiana. IDEM, Indianapolis, IN

IDEM (1990b) State of Indiana, Indiana Department of Environmental Management Authorization to discharge under the National Pollutant Discharge Elimination System (NPDES) permit no. IN 0001210 Aluminum Company of America, Lafayette, IN. 32 pp

IDEM (1994) Draft expanded site inspection report for A.O. Smith (Westinghouse), Union City, Randolph County, Indiana. U.S. EPA ID:IND000819904, August 31, 1994. Indiana Department of Environmental Management, Indianapolis, IN

Kacir B (1983) Re: United States v. Westinghouse - Rule 30(b)(6) Requests; August 12, 1983 letter to K.A. Reich, Land \& Natural Resources Division, U.S. Department of Justice. Jones, Day, Reavis \& Pogue. Cleveland, OH. 32 pp

Katz M, Gaufin AR (1953) The effects of sewage pollution on the fish population of a midwestern stream. Trans Am Fish Soc 82:156-165

Katz M, Howard WC (1955) The length and growth of 0-year class creek chubs in relation to domestic pollution. Trans Am Fish Soc 84: 228-238

Moshenko RW, Gee JH (1973) Diet, time, and place of spawning, and environments occupied by creek chub (Semotilus atromaculatus) in the Mink River, Manitoba. J Fish 
Res Board Can 30:357-362

Munson TO (1971) Preliminary report of Inerteen environmental survey at Bloomington Distribution Apparatus Plant. Westinghouse Ocean Research Laboratory. 15 pp

Olmsted LL, Cloutman DG (1974) Repopulation after a fish kill in Mud Creek, Washington County, Arkansas following pesticide pollution. Trans Am Fish Soc 103:79-87

Powell RL (1996) A summary report on conditions at the Winston-Thomas Wastewater Treatment Facility Bloomington, Indiana. Earth Tech, Bloomington, Indiana prepared for U.S. Environmental Protection Agency, Region V, Chicago, IL

Sciences International Inc. (1998) Results of the December 1997 field sampling effort to investigate potential sources of PCB contamination in the Little Mississenewa River. Prepared for United Technologies Automotive Systems, Union City, Indiana. 30 pp

Storck T, Momot WT (1981) Movement of creek chub in a small Ohio stream. Ohio Acad Sci 81:9-13

Trautman MB (1981) The fishes of Ohio. Ohio State University Press. Columbus, $\mathrm{OH}$ U.S. Environmental Protection Agency (U.S. EPA) (2001) POLREP 1 (Initial) Shelly Ditch Time-Critical Removal Action, Crawfordsville, Montgomery County, Indiana, June 7, 
2001. U.S. EPA, Region V, Chicago, IL

U.S. EPA (2003) POLREP 9 Shelly Ditch Time-Critical Removal Action, Crawfordsville, Montgomery County, Indiana, May 7, 2003. U.S. EPA, Region V, Chicago, IL

U.S. EPA (2004) Record of Decision (ROD) for the Little Mississenewa River Site, Union City, Randolph County, Indiana. U.S. EPA, Region V, Chicago, IL. 63 pp

U.S. EPA (2010) Biological indicators of watershed health. http://www.epa.gov/bioiweb1 /html/fish_minnows.html. Accessed October 27, 2010.

U.S. EPA (2011) U.S. Environmental Protection Agency Pollution/Situation Report Alcoa Oil Spill - Removal POLREP, \#6 Final PolRep Alcoa Oil Spill, July 7, 2011. U.S. EPA, Region V, Chicago, IL

U.S. Fish and Wildlife Service (U.S. FWS) (1987) U.S. FWS comment letter dated September 3, 1987 to Ms. Nancy Maloley, Indiana Department of Environmental Management Office of Water Management regarding a proposed modification to NPDES permit IN0003107 for Sheller-Globe, Union City, Indiana. USFWS, Ecological Services Office Bloomington, Indiana

United Technologies Automotive (UTA) (1994a) Pat Perrelli, United Technologies Automotive letter dated July 5, 1994 to Ms. Carla Gill, IDEM, Indianapolis, IN 
UTA (1994b) James C. Heim, United Technologies Automotive letter dated September 29, 1994 to IDEM, Indianapolis, IN requesting a renewal of NPDES permit IN003107. 4pp

Walker RH, Adams GL (2016) Ecological factors influencing movement of creek chub in an intermittent stream of the Ozark Mountains, Arkansas. Ecol. Freshw Fish 25:190-202

Westinghouse Electronic Corporation Aquatechnics (Westinghouse) (1971)

Westinghouse Electronic Corporation Distribution Apparatus Division Bloomington, Indiana - Industrial Wastewater Sampling and Testing Program. July 29, 1971 
Fig. 1. Schematic pathways of PCBs released by Westinghouse to the environment of Monroe and Owen County, Indiana. 


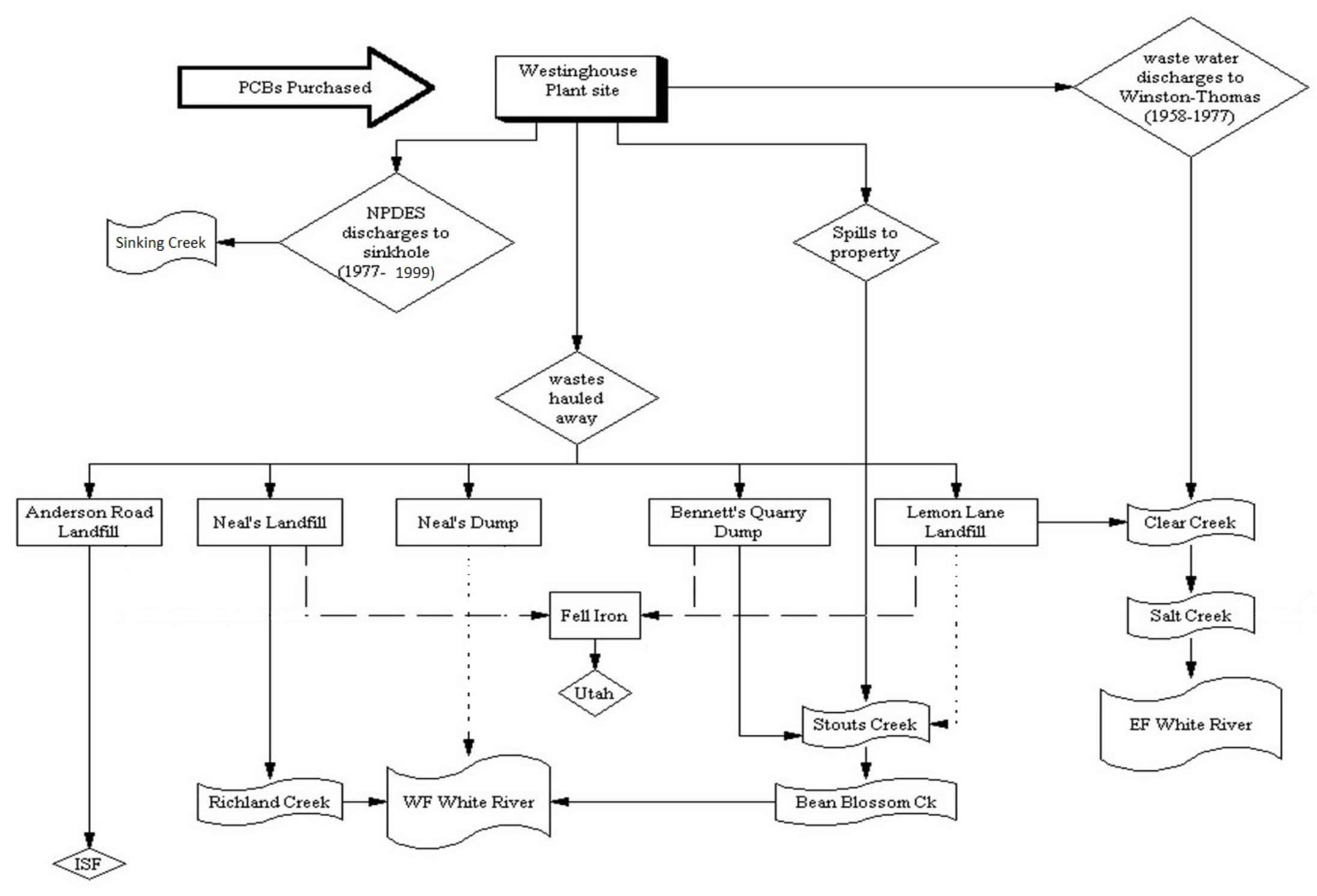


Fig. 2. Creek chub sampling locations from eight PCB-contaminated streams: upper and lower Clear Creek (ICS and CC), Conards Branch / Richland Creek (CB), Stouts Creek (SC), Sinking Creek (ABB) in Monroe County, Pleasant Run Creek (PR) in Lawrence County, the Little Mississenewa River (LM1 and LM2) in Randolph County, Elliot Ditch / Wea Creek (ED1 and ED2) in Tippecanoe County, and Shelly Ditch (SD) in Montgomery County, Indiana. Also included are two uncontaminated reference sites: Little Indian Creek (LI), and Brummett Creek (BRUM), Greene and Monroe Counties and a slightly elevated background stream, Burnetts Creek (BC) in Tippecanoe County, Indiana. 


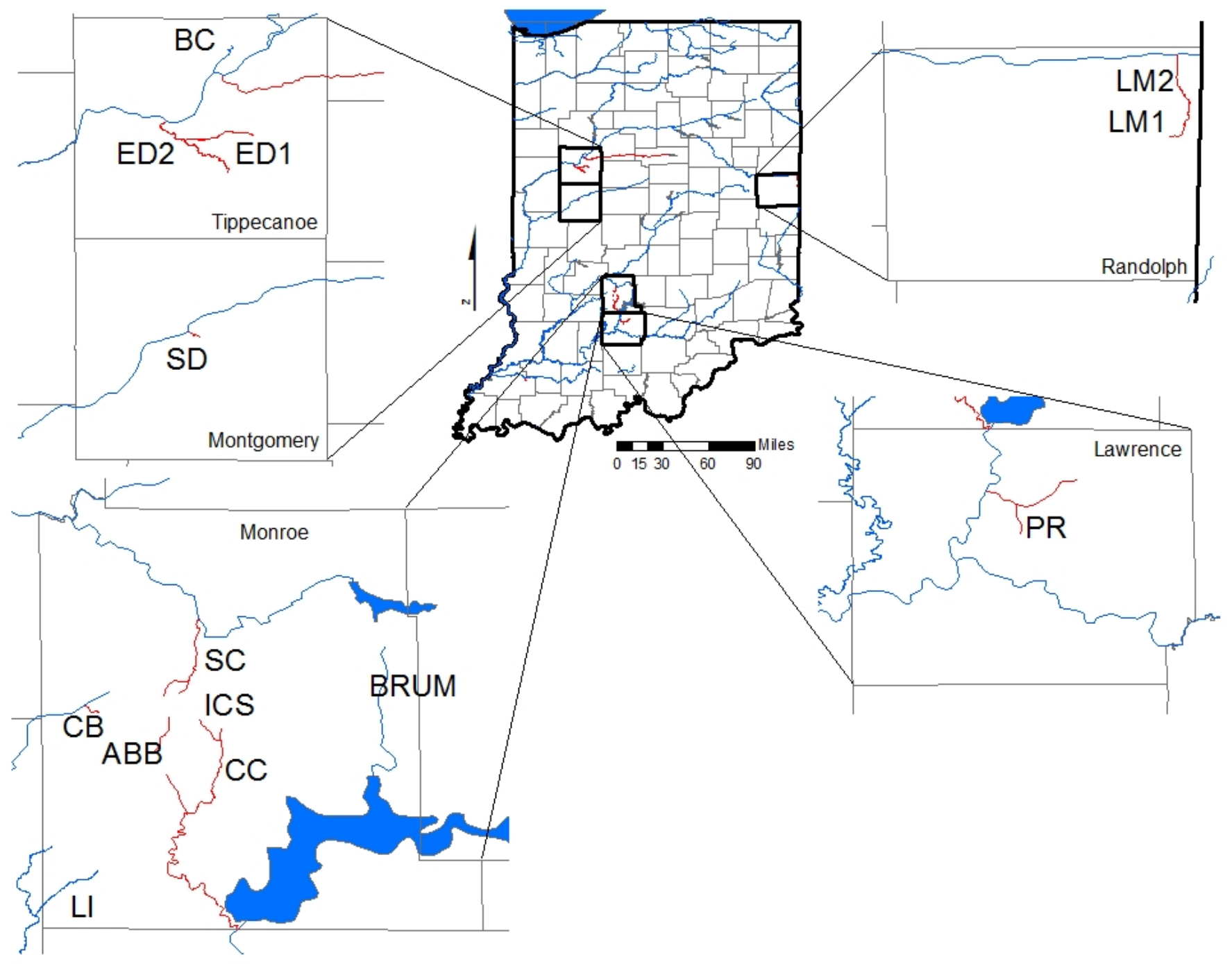


Table 1. Concentrations of PCBs in whole body creek chub samples $(\mu \mathrm{g} / \mathrm{g}$, wet weight) and sediment $(\mu \mathrm{g} / \mathrm{g}$, dry weight) from eight PCB-contaminated streams: Clear Creek (ICS and CC), Conards Branch / Richland Creek (CB), Stouts Creek (SC), Sinking Creek (ABB) in Monroe County, Pleasant Run Creek (PR) in Lawrence County, the Little Mississenewa River (LM1 and LM2) in Randolph County, Elliot Ditch / Wea Creek (ED1 and ED2) in Tippecanoe County, and Shelly Ditch (SD) in Montgomery County, Indiana. Also included are two uncontaminated reference sites: Little Indian Creek (LI), and Brummett Creek (BRUM), Greene and Monroe Counties and a slightly elevated background stream, Burnetts Creek (BC) in Tippecanoe County, Indiana.

\begin{tabular}{|c|c|c|c|c|c|c|c|}
\hline \multirow[b]{2}{*}{ Site } & \multicolumn{3}{|c|}{ Mean whole body PCBs } & \multicolumn{3}{|c|}{ Mean sediment PCBs } & \multirow[b]{2}{*}{$\begin{array}{l}\text { PCB } \\
\text { Grouping }\end{array}$} \\
\hline & $\mu \mathrm{g} / \mathrm{g} \pm \mathrm{sd}$ & $\mathrm{N}$ & $\begin{array}{l}\text { sample } \\
\text { year }\end{array}$ & $\mu \mathrm{g} / \mathrm{g} \pm \mathrm{sd}$ & $\mathrm{N}$ & $\begin{array}{l}\text { sample } \\
\text { year }\end{array}$ & \\
\hline LI & $0.01 \pm 0.004$ & 6 & 1999 & NA & & & reference \\
\hline $\mathrm{BC}$ & $0.10 \pm 0.09$ & 5 & 2003 & NA & & & reference \\
\hline BRUM & $0.014 \pm 0.002$ & 3 & 2010 & 0.006 & 1 & 2010 & reference \\
\hline LM1 & $13.1 \pm 25$ & 12 & 2001 & $27.7 \pm 5.9$ & 4 & 2002 & lowR \\
\hline PR & $4.2 \pm 1.3$ & 3 & 2009 & & & & lowR \\
\hline SC & $0.9 \pm 0.25$ & 5 & 2003 & & & & lowR \\
\hline SC & $1.26 \pm 0.57$ & 7 & 2004 & $0.17 \pm 0.02$ & 3 & 2004 & lowR \\
\hline ABB & $0.94 \pm 0.34$ & 3 & 2004 & NA & & & medium \\
\hline CB & $12.1 \pm 3.1$ & 8 & 1998 & $1.9 \pm 0.9$ & 5 & 1998 & medium \\
\hline $\mathrm{CB}$ & $0.84 \pm 0.33$ & 6 & 2004 & & & & medium \\
\hline $\mathrm{CC}$ & $0.98 \pm 0.68$ & 10 & 2003 & $0.6 \pm 0.1$ & 3 & 1997 & medium \\
\hline ICS & $19.2 \pm 3.2$ & 9 & 1996 & $2.2 \pm 0.03$ & 5 & 1996 & high \\
\hline ICS & $1.8 \pm 1.0$ & 8 & 2004 & & & & high \\
\hline ED1 & $5.6 \pm 2.7$ & 7 & 2001 & $0.69 \pm 0.04$ & 3 & 2011 & high \\
\hline ED2 & $5.3 \pm 2.8$ & 4 & 2001 & $0.53 \pm 0.05$ & 3 & 2011 & high \\
\hline LM1 & 15.0 & $1^{a}$ & 1993 & & & & high \\
\hline LM2 & $24.8 \pm 10.2$ & 10 & 2001 & $3.4 \pm 2.2$ & 5 & 2002 & high \\
\hline LM2 & $5.9 \pm 3.2$ & 4 & 2003 & & & & high \\
\hline PR & $359 \pm 87$ & 6 & 2001 & $7.1 \pm 1.5$ & 14 & 2001 & high \\
\hline SD & $16.9+0.05$ & 3 & 2001 & $2.1+0.6$ & 5 & 2000 & high \\
\hline
\end{tabular}

$\mathrm{N}$ - number of samples; sd - standard deviation; Reference - reference site; lowR - site has been remediated resulting in significant PCB load reductions; medium - moderately contaminated; high - high contamination levels. ${ }^{a}$ - composite of 15. 
CHAPTER 2 - Hepatic oxidative stress and lipidosis in Semotilus atromaculatus from PCB-contaminated streams in Indiana

\begin{abstract}
Water source contamination with polychlorinated biphenyls (PCBs) commonly affects basic cellular functions of exposed organisms. The purpose of this study was to determine whether PCB contamination causes oxidative stress in the liver of creek chubs (Semolitus atromaculatus) in several central Indiana streams. The impact of PCB contamination was measured by examining the activity of indicators of oxidative stress and the presence and severity of lipidosis in creek chub livers. Sampled streams were sorted into reference (0.0-0.1 ppm fish tissue), low or recently remediated PCB (0.1-0.5 ppm fish tissue), medium PCB (0.6-1.0 ppm) and high PCB (>1.0 ppm) comparison groups. Additional fish were collected from three high level PCB sites after remediation. The fish were collected using standard electrofishing techniques during the spring. The livers were removed; half was prepared for histological analysis and half was frozen with liquid nitrogen to be prepared as $5 \%$ cytosols for analysis. The activities of superoxide dismutase, catalase, glutathione peroxidase, and glutathione reductase were determined spectrophotometrically. Hepatic oxidative stress enzymes of the fish from PCB contaminated streams have been adversely impacted. Activities of catalase and glutathione reductase were significantly increased $(p<0.05)$ concurrent with PCB stream contamination category. The activity of glutathione peroxidase in the medium PCB stream category was also increased. Histological examination determined lipidosis was not by
\end{abstract}


itself a useful biomarker of PCB stress, although catalase significantly increased and the other 3 enzyme activities trended higher with the increasing severity of lipidosis.

\section{Introduction}

Industrial uses of polychlorinated biphenyls (PCBs) began in the United States in 1929 (Jensen 1972) and the accumulation of PCB in fish and wildlife tissues was first reported in 1966 (Jensen 1972). Efforts to understand pathways from industrial uses to the environment quickly sprang up due to concerns raised by these early findings (Nisbet and Sarofim 1972; U.S. EPA 1976). The widespread PCB contamination of ecosystems was soon being discovered throughout the world (Peakall and Lincer 1970; Geyer et al. 1984; Tanabe 1988). Efforts to understand the toxic effects of PCBs to fish and wildlife began in the late 1960s.

From the earliest fish toxicity studies, PCBs have been shown to induce enlarged livers (hepatomegaly) (Hansen et al. 1976; Cleland et al. 1988), and lipidosis (Nimmo et al.1975; Hacking et al. 1977; Freeman et al. 1982). Severe lipidosis was observed in largemouth bass (Micropterus salmoides) from Hartwell Reservoir, in Savannah, GA, a PCB-contaminated site (Teh et al. 1997). Even PCB-contaminated fish fed to mink (Neovison vison) caused hepatic lipidosis in mink (Restum et al.1998).

The liver performs several roles in lipid metabolism, including the synthesis of cholesterol and the production of triglycerides (lipogenesis). Lipidosis on the other hand, has been defined as a "lysosomal storage disorder of lipids" (Reasor 1981). Reasor (1989) further explains lipidosis as impairment of phospholipid catabolism (catabolism of 
lipids happens through the action of lysosomes). Lipidosis is characteristic of failed or incomplete autophagy. Moore et al. (2006) states that lysosomal membrane integrity and stability appears to be a generic indicator of cellular well-being in eukaryotes. Cellular homeostasis is contingent upon the reduction / oxidation (REDOX) system being in balance (Trachootham et al. 2008). This balance between pro-oxidants (i.e. reactive oxygen species [ROS]), and antioxidants, including enzymes and non-enzymes (such as vitamins), can be upset by the introduction of contaminants. While minor amounts of lipid peroxidation (LPO) occurs continually in redox balanced cells, excessive LPO of cell membrane fatty acids threatens cell survival (Mylonas and Kouretas 1999). One byproduct of LPO is the production of malondialdehyde (MDA), a limited (Janero 1990) but somewhat useful indicator of LPO (Buha et al. 2015). Enzymes that defend against ROS include catalase (CAT), glutathione peroxidase (GPx), glutathione reductase (GRx), and superoxide dismutase (SOD). More recently PCBs have been shown to induce oxidative stress in the liver which can lead to increased LPO (Gillardin et al. 2009; VegaLopez et al. 2009). Both dioxin-like (DL) and non-dioxin like (NDL) PCB congeners have been shown to induce oxidative stress (Fadhel et al. 2002; Dutta et al. 2008; Marabini et al. 2011) and PCB-induced oxidative stress has been implicated in both increased LPO and genotoxic damage in hepatocytes (Glauert et al. 2008).

This study sought to assess whether these hepatic endpoints are sensitive indicators of PCB water quality impairments. The creek chub (Semotilus atromaculatus) is commonly found throughout Indiana in suitable numbers which facilitated comparisons of fish liver health between PCB-contaminated streams (Indiana State Department of Health 2006) and reference streams. Therefore, this study examined histologic liver 
condition and liver enzyme levels of creek chubs from streams that are highly contaminated with PCBs and reference streams to determine if harm is occurring to these fish.

\section{Methods}

Study Sites and PCB Exposures

Study sites were selected at and downstream of significant PCB contaminant sources as identified by the State of Indiana on its Clean Water Act §303(d) list of impaired waterways due to the significant levels of PCBs. All of these other PCB-contaminated streams have been associated with significant Comprehensive Environmental Response, Compensation and Liability Act (CERCLA) investigations and cleanups based on PCBs as the contaminant of concern and thousands of fish tissue, water, and sediment samples that were collected and chemically analyzed for PCBs (U.S. EPA 2012a). Sources of PCB-contamination include National Priorities List (NPL) CERCLA sites [Lemon Lane Landfill (LL), Neal's Landfill (NL), Bennetts Dump (BD) in Monroe County], and CERCLA non-NPL removal action sites (former Westinghouse plant in Monroe County, United Technologies Automotive (UTA) and Westinghouse in Randolph County, Raybestos in Montgomery County, GM Foundry in Lawrence County). Creek chubs were collected at 14 sites from 11 streams in east central, west central and south central Indiana, U.S.A. (Fig. 1). From the West Fork White River drainage, five PCB-contaminated streams were sampled: upper and lower Clear Creek (ICS and CC), Conards Branch / Richland Creek (CB), Stouts Creek (SC), Sinking Creek (ABB), and Pleasant Run Creek (PR) in Monroe

and Lawrence Counties, Indiana. Two uncontaminated reference sites in the White River 
drainage were also sampled, including Little Indian Creek (LI), and Brummett Creek (BRUM), Greene and Monroe Counties, Indiana (Fig. 1). From the Wabash River drainage, 3 PCB-contaminated streams were sampled: the Little Mississenewa River (LM1 and LM2) in Randolph County, Elliot Ditch / Wea Creek (ED1 and ED2) in Tippecanoe County, and Shelly Ditch (SD) in Montgomery County, Indiana. Burnetts Creek (BC) from the Wabash River drainage in Tippecanoe County was also considered a reference site, although $\mathrm{PCB}$ concentrations in $\mathrm{BC}$ fish $(0.1 \mu \mathrm{g} / \mathrm{g})$ were slightly higher than fish from LI and BRUM $(0.01-0.02 \mu \mathrm{g} / \mathrm{g})$, but still an order of magnitude below all other PCB-contaminated sites.

The ambient water quality criteria for the protection of freshwater aquatic life from acute effects is $0.014 \mu \mathrm{g} / \mathrm{l}$ (14 parts per trillion [ppt]) (U.S. EPA 2012b). During the timeframe which this investigation was conducted (1995 - 2009), PCBs were entering these streams anywhere from $100-470,000$ ppt. Table 1 summarizes the relative PCB contamination of sediment and whole creek chubs at these sample locations during the timeframe in which our fish samples were collected. Only very low concentrations of PCBs were found in fish at $\mathrm{LI}$ and BRUM $(0.01-0.02 \mu \mathrm{g} / \mathrm{g})$ confirming that these are suitable to represent background conditions for Indiana creek chubs. Study streams were sorted into categories of reference (Ref), historically low or recently remediated (LowR), medium (Med) and high (High) based on the average whole body fish tissue PCB concentration or the recent completion of sediment remediation in the stream reach which resulted in the reduction of PCBs in fish tissue by two orders of magnitude. 


\section{Liver Histology Survey}

Monthly collections of 5-15 individual creek chubs were collected between April 1999 April 2000 and March 2001 - February 2004 at all sites, usually within 48 hours, using a battery backpack pulsed-DC electro-fishing unit (model ABP-3-450V, ETS Electrofishing LLC, Verona, WI) capable of $2-3$ Amp output. Fish were preserved by immersion fixation in $10 \%$ phosphate buffered formalin.

Livers from 587 of these fish were processed histologically (Table 2). The body cavity of the fish was opened with an incision on the ventral surface from the anus to just distal to the gill openings. Incisions were also made along the lateral surfaces of the fish at both ends of the ventral incision in order to expose the body cavity. Livers were embedded in paraffin and $5 \mu \mathrm{m}$ serial sections were made using a Reichert-Jung Model 2030 microtome (Depew, NY). The slides were stained using the standard hematoxylin (H) and eosin (E) method (Presnell and Schreibman 1997). Hematoxylin and E stained sections were evaluated using a Leica DFC425C digital camera affixed to a Leica microscope (Model DM2000, Heerbrugg, Switzerland) and liver section images were taken using Leica Application Suite 3.8.0 imaging software. A qualitative rating scale was used to classify the degree of liver "lipidosis" $(1=$ normal, $2=$ moderate, $3=$ high, $4=$ severe) (Fig. 2). One individual rated all samples to minimize sampling bias. No differentiation was made between microvesicular and macrovesicular lipidosis.

\section{Liver Enzymes}

Creek chubs ( $n=-12 /$ site) were captured from all 8 southern sites (Fig. 1) from March 24 through April 9, 2009 and from 4 of our 6 northern sites April 24 to April 27, 2009 for a 
total of 12 of the 14 previously described locations (Shelly Ditch and upper Elliot Ditch were not sampled). Creek chubs were transported alive in coolers to the laboratory for individually processing within hours of capture. Creek chubs were anesthetized using tricane methanesulfonate (MS222) and measured using total weight (g) and total length ( $T L$ in $\mathrm{mm}$ ). Fish were euthanized by severing the spinal cord at the base of the head. Blood was collected in heparinized capillary tubes, and livers were excised whole from the carcass. Half of the liver was placed in a cryrotube and snap frozen with liquid nitrogen, while the other half of the liver was transported to an adjacent room and placed in $10 \%$ neutral buffered formalin (NBF). The remaining fish carcass was also preserved in NBF for later assessment of visible deformities and gonad weight (Chapter 3). Blood analyses are detailed in Chapter 3. Fish scales were taken for estimating age (Chapter 4).

Frozen livers (300mg) were homogenized in $4.7 \mathrm{ml}$ of $0.1 \mathrm{M}$ sodium phosphate/5mM EDTA buffer ( $\mathrm{pH}$ 7.6) using a Brinkmann Polytron homogenizer (Glen Mills, Inc. Clifton, NJ). The tissue cytosol and pellet were separated using 2 consecutive centrifuge spins (1500 $\mathrm{g}$ for $10 \mathrm{~min} ; 100,000 \mathrm{~g}$ for $60 \mathrm{~min}$ ). Aliquots $(10 \mu \mathrm{L})$ of the supernatant from the second centrifugation were used to determine enzyme activities. The original microsomal pellets were resuspended and assayed for protein concentration using a bovine serum albumin standard (Lowry et al. 1951).

Antioxidant enzyme activity was measured spectrophotometrically and expressed as units/mg protein. Glutathione peroxidase (GPx) activity was determined at $340 \mathrm{~nm}$ in $50 \mathrm{mM}$ Tris/0.1 mm EDTA pH 7.6 (Tappel 1978). One GPx activity unit was defined as the amount of enzyme that transforms $1 \mu \mathrm{mol}$ of NADPH to NADP in 1 minute at $37^{\circ} \mathrm{C}$. Glutathione reductase (GRx) activity was determined by the NADPH-dependent reduction 
of oxidized glutathione (GSSG) to GSH at $340 \mathrm{~nm}$ in $0.1 \mathrm{M}$ sodium phosphate buffer ( $\mathrm{pH}$ 7.6) (Carlberg and Mannervik 1975). The oxidation of $1 \mathrm{nmol} \mathrm{NADPH/min}$ is defined as a unit of GRx activity. Cytosolic superoxide dismutase (SOD) activity was measured using xanthine and xanthine oxidase as a superoxide generator and cytochrome $\mathrm{c}$ as an indicator in the absence of SOD at $550 \mathrm{~nm}$ in $50 \mathrm{mM}$ potassium phosphate buffer $/ 0.1 \mathrm{mM}$ EDTA (pH 7.8) (Crapo et al. 1978). Fifty percent inhibition (IC50) of cytochrome c in the presence of superoxide anion was defined as a unit of SOD activity. Catalase (CAT) activity was determined by measuring the decomposition of hydrogen peroxide in the presence of catalase at $240 \mathrm{~nm}$ (Luck 1963). One unit of CAT activity was defined as the amount of enzyme that liberated half the peroxide oxygen from hydrogen peroxide solution (0.03\%, pH 7.0) in 100 seconds at $25^{\circ} \mathrm{C}$. All chemicals for the liver enzyme analyses were purchased from Sigma Aldrich (St. Louis, MO), unless otherwise noted.

\section{Statistics}

All statistical analyses were conducted using R (R Core Group 2013). All graphs were created in Excel (Microsoft Corp., Seattle, WA). Enzyme data were compared across sex via t-test, and across site, PCB contaminant classes and lipidosis scores via ANOVA. Significant difference of means or significance in the model equation of $\alpha \leq 0.05$ were denoted.

\section{Results}

Males from the headwaters of Clear Creek (ICS) had the highest mean concentrations of 
CAT activity / unit protein $(1.17 \pm 0.96), \mathrm{GPx}(37.3 \pm 21.9)$, and GRx $(23.4 \pm 19.8)$ of any of the other streams and lower Clear Creek (CC) had the second highest values of these enzymes, including SOD $(3.55 \pm 1.41)$ (Table 3$)$. GRx from males at ICS was significantly different among one of the reference sites $(11.0 \pm 7.3)($ ANOVA, $p<0.006)($ Table 3$)$. Mean male GRx concentrations at two recently remediated sites LM1 $(13.2 \pm 7.8)$ and SC $(12.1 \pm 6.3)$, were similar to reference site GRx concentrations. Female enzymes were not significantly different among sites (Table 4). When males and females were combined within sites, CAT was significantly increased as PCB category increased (Fig.3a). GRx was significantly higher in the medium PCB contamination category in comparison to reference and low/recently remediated PCB streams (Fig. 3c). Catalase was the only enzyme significantly higher in males than females (12.8 and 6.5 , respectively; $p=0.005)$.

Lipidosis scores were also higher in males than in females (2.7 and 1.5, respectively; $p<0.001$ ). Lipidosis was confirmed in nearly all male fish regardless of whether the fish were from PCB-contaminated or reference streams (Fig. 5). No females were identified with high or severe lipidosis from any of the sites sampled in 2009. Catalase was the only enzyme that was significantly higher in the severe lipidosis category ( $p=0.003)$, although GPx, GRx and SOD were elevated (Fig. 4).

\section{Discussion}

\section{Anti-oxidizing Enzymes}

Anti-oxidizing enzyme response has been shown to vary by contaminant class and concentration, from species to species and type of tissue tested (DiGiulio et al. 1989). 
The oxidative stress enzymes CAT and GRx appeared to be upregulated as stream PCB contamination increased (as indicated by representative whole body creek chub total PCB concentrations). Concentrations of PCBs in fish and sediment in the contaminated streams have been relatively stable for many years. Several remedial measures have been taken at various times to control PCB discharges at most of these contaminated sites, and creek chub PCB concentrations have generally declined in response to these actions. Because PCBs are very persistent in the environment and bioaccumulate exponentially, even low levels of PCBs in sediment can cause elevated levels of PCBs in fish. These fish tissue PCB levels can be compared to various indicators of stress in fish.

When Girardinichthys viviparus were challenged in a laboratory setting with Inerteen, an industrial formation of PCBs, CAT increased in liver (Vega-Lopez et al. 2007). Consistent with our findings, baseline CAT has been reported to be higher in males than females of Ameca splendens (Vega-Lopez et al. 2009). ROS increased and genes for the enzymes that counteract ROS (SOD, CAT and GPX) were upregulated when Gobiocypris rarus larvae were stressed with increasing concentrations of Aroclor 1254 (Wu et al. 2014). This is somewhat consistent with our results that indicated CAT and GRx were increased in both male and female adult creek chubs to relatively increased PCB levels. The constant PCB exposure at our study streams, as opposed to single laboratory challenges, might explain the strength of our observed response. In several studies, CAT and GPx return to near control levels after a period of several days to a week, likely corresponding to the fleeting persistence of the initial ROS insult and the elimination of the exposure through metabolism and volatilization of a water borne exposure. 


\section{Lipidosis}

We used simple histology practices to determine if and to what degree lipidosis was present in the livers of creek chubs. Macrovesicular lipidosis was observed most often, and occurs when there is a reversible increase in fat build up in the cell due to altered fatty acid metabolism. Given that all of the enzymes trended higher as the severity of lipidosis increased (Fig. 4), it is likely that lipidosis and lipid peroxidation (LPO) are inextricably linked. Given the confounding factors associated with a toxicity test scenario, including dietary and captivity stresses, it is uncertain how to design a cause - effect experiment that could link PCB exposure to hepatic lipidosis. Some authors have argued that analyzing MDA is an important indicator of LPO that positively correlates with lipidosis (Ameur et al. 2012) while others have pointed out weaknesses and limitations of examining MDA and thiobarbituric acid reactive substances (TBARS) as indicators of LPO (Janero 1990, Draper et al. 1993, Lefevre et al. 1998) In addition, the use of additional histology staining techniques (e.g. oil red O, periodic acid Schiff with diastase, iron stains) may also differentiate between macro- and microvesicular lipidosis (Brunt 2007). Microvesicular lipidosis is a marker of mitochondrial injury (Hift 2005).

Despite the fact that all of the historical PCB fish toxicity studies found hepatomegaly and lipidosis, we have not proven a cause effect relationship between PCBs and lipidosis in this study. Ordinary metabolic processes involved in changing activity budgets, food and nutrient absorption, oocyte formation and breeding behavior can also bring about lipidosis. This study could not separate out lipidosis caused by PCBs versus the natural responses to spawning energetics. Both liver function and/or lipid 
metabolism are altered during the spawning season. Males at our cleanest PCB reference site (BRUM) were in peak spawning condition when sampled. Male peak activity was likely associated with reduced feeding during this timeframe. Building nests, defending territories, attracting mates could result in macrovesicular lipidosis. In addition, females that were in late stage oogenesis also had normal to moderate lipidosis regardless of the site. The female liver plays an important role in vitellogenesis and oocyte formation (Mommsen and Walsh 1988) and this importance is highlighted by the fact that female creek chub liver somatic indices are always higher than males $(2.6 \%$ and $2.0 \%$, respectively, $p$-value $=0.018)$. Late in the oocyte maturation stage, the transfer of significant amounts of egg yolk protein from the liver to the oocytes may result in vacuolation of the liver, giving the appearance of lipidosis. In our survey, females with higher GSI had much lower lipidosis scores (ANOVA, p-value <0.0003). This seems to indicate that in females, robust fecundity was associated with healthy livers. It is likely that hepatic oxidative stress may correlate well with reproductive oxidative stress (Aly 2013; Liu et al. 2016) and that would likely be of a more compelling nature (see Chapter 3). Varying degrees of reproductive failure in creek chubs at some of these PCBcontaminated sites have been observed (Henshel et al. 2006); oxidative stress (via altered liver function) might have been a contributing factor.

This present study confirms the relationship between PCBs and increased oxidative stress. There are many serious impacts to cells from increased oxidative stress, including DNA and mitochondrial membrane damage which encourages programmed cell death, or apoptosis (Wu et al. 2014). Oxidative stress has also been shown to increase LPO, which may be the cause or byproduct of several diseases and pathological 
conditions of the kidneys and respiratory, digestive and nervous systems (Mylonas and Kouretas 1999). Lipidosis is a significant metabolic alteration that can be evidence of serious metabolic impairment and could have significant adverse consequences to reproduction and the health of the animal. Great Britain's Pesticide Safety Department considers the disruption of lipid metabolism and hepatomegaly a significant toxic effect (Andrews 2005). Although creek chubs are experiencing oxidative stress in these PCBcontaminated streams, the relationship to lipidosis was not determined. Future studies should examine both male and female livers in every month throughout the year from PCB-contaminated and uncontaminated settings with a variety of histology staining agents (Brunt 2007).

\section{References}

Aly HAA (2013) Aroclor 1254 induced oxidative stress and mitochondria mediated apoptosis in adult rat sperm in vitro. Environ Toxicol Pharmacol 36:274-283

Ameur W B, de Lapuente J, El Megdiche Y, Barhoumi B, Trabelsi S, Camps L, Serret J, Ramos-López D, Gonzalez-Linares J, Driss MR, Borràs M (2012) Oxidative stress, genotoxicity and histopathology biomarker responses in mullet (Mugil cephalus) and sea bass (Dicentrarchus labrax) liver from Bizerte Lagoon (Tunisia). Mar Pollut Bull 64:241251

Andrews D (2005) PSD Guidance Document: Interpretation of Liver Enlargement in 
Regulatory Toxicity Studies, May 25, 2005. Pesticides Safety Department, an Agency of the Health and Safety Executive, Department of the Environment, United Kingdom. Kings Pool, 3 Peasholme Green, York, YO1 7PX, UK. 19 pp

Brunt EM (2007) Pathology of fatty liver disease. Modern Pathology 20:S40-S48

Buha A, Antonijevic B, Milovanovic V, Jankovic S, Bulat Z, Matovic V (2015)

Polychlorinated biphenyls as oxidative stress inducers in liver of subacutely exposed rats: implication for dose-dependence toxicity and benchmark dose concept. Environ Res 136: 309-317

Carlberg I, Mannervik B (1975) Purification and characterization of the flavoenzyme glutathione reductase from rat liver. J Bio Chem 250:5475-5480

Cleland GB, McElroy PJ, Sonstegard RA (1988) The effect of dietary exposure to Arochlor 1254 and/or mirex on humoral immune expression of rainbow trout (Salmo gairdneri). Aquat Toxicol (Amst.) 12:141-146

Crapo JD, McCord JM, Fridovich I (1978) Preparation and assay of superoxide dismutases. Methods Enzymol 53:382-393

DiGuilio RT, Washburn PC, Wenning RJ (1989) Biochemical responses in aquatic animals: a review of determinants of oxidative stress. Environ Toxicol Chem 8:1103-1123 
Draper HH, Squires EJ, Mahmoodi H, Wu J, Agarwal S, Hadley M (1993) A comparative evaluation of thiobarbituric acid methods for determination of malondialdehyde in biological materials. Free Radical Biol Med 15:353-363

Dutta SK, Ghosh S, De S, Hoffman EP (2008) CYP1A1 and MT1K are congener specific biomarker genes for liver diseases induced by PCBs. Environ Toxicol Pharmacol 25:218221

Fadhel Z, Lu Z, Robertson LW, Glauert HP (2002) Effect of 3,3',4,4'-tetrachlorobiphenyl and $2,2^{\prime}, 4,4^{\prime}, 5,5^{\prime}$-hexachlorobiphenyl on the induction of hepatic lipid peroxidation and cytochrome P-450 associated enzyme activities in rats. Toxicology 175:15-25

Freeman HC, Sangalang GB, Fleming B (1982) The sublethal effects of polychlorinated biphenyl (Arochlor 1254) diet on the Atlantic cod (Gadus morhua). Sci Total Environ 24:111

Geyer H, Freitag D, Korte F (1984) Polychlorinated biphenyls (PCBs) in the marine environment, particularly in the Mediterranean. Ecotox Environ Safety 8:129-151

Gillardin V, Silvestre F, Divoy C, Thome' JP, Kestemont P (2009) Effects of Aroclor 1254 on oxidative stress in developing Xenopus laevis tadpoles. Ecotoxicol Environ Safety 72:546-551 
Glauert HP, Tharappel JC, Lu Z, Stemm D, Banerjee S, Chan LS, Lee EY, Lehmler HJ, Robertson LW, Spear BT (2008) Role of oxidative stress in the promoting activities of PCBs. Environ Toxicol Pharmacol 25:247-250

Hacking MA, Budd J, Hodson K. (1977) The ultrastructure of the liver of the rainbow trout: normal structure and modifications after chronic administration of a polychlorinated biphenyl Arochlor 1254. Can J Zool 56:477-491

Hansen GL, Wiekhorst WB, Simon J. (1976) Effects of dietary Aroclor 1242 on channel catfish (Ictalurus punctatus) and the selective accumulation of PCB components. J Fish Res Board Can 33:1343-1352

Henshel D, Sparks DW, Simon TP, Tosick MJ (2006) Age structure and growth of Semotilis atromaculatus (Mitchill) in PCB-contaminated streams. J Fish Biol 68:44-62

Hift RJ (2005) Fatty liver disease: steatosis and steatohepatitis. Contin Med Educ 23:384388

Indiana State Department of Health (ISDH) (2006) 2006 Indiana Fish Consumption Advisory. Indianapolis, IN. 24 pp

Jensen S (1972) The PCB story. Ambio 1(4):123-131 
Janero DR (1990) Malondialdehyde and thiobarbituric acid-reactivity as diagnostic indices of lipid peroxidation and peroxidative tissue injury. Free Radical Biol Med 9:515-540.

Lefevre G, Beljean-Leymarie M, Beyerle F, Bonnefont-Rousselot D, Cristol JP, Therond P, Torreilles J (1998) Evaluation of lipid peroxidation by measuring thiobarbituric acid reactive substances. Ann Biol Clin (Paris) 3:305-319.

Liu H, Nie FH, Lin HY, Ma Y, Ju XH, Chen JJ, Gooneratne R (2016) Developmental toxicity, oxidative stress, and related gene expression induced by dioxin-like PCB 126 in zebrafish (Danio rerio). Environ Toxicol 31:295-303

Lowry O, Rosebrough NJ, Farr AL, Randal RJ (1951) Protein measurements with Folin phenol reagent. J Biol Chem 193:265-275.

Luck H (1963) Catalase. In: Bergmeryer HU (ed), Methods of enzymatic analysis. Academic Press, New York, pp 885-888

Marabini L, Calò R, Fucile S (2011) Genotoxic effects of polychlorinated biphenyls (PCB $153,138,101,118)$ in a fish cell line (RTG-2). Toxicol in Vitro 25:1045-1052

Mommsen TP, Walsh PJ (1988) Vitellogenesis and oocyte assembly. In: (Mommsen TP, Walsh PJ (eds) Fish Physiology Volume XIA. Academic Press, New York, pp 347-406 
Moore MN, Allen JI, McVeigh A (2006) Environmental prognostics: An integrated model supporting lysosomal stress responses as predictive biomarkers of animal health status. Mar Environ Res 61:278-304

Mylonas C, Kouretas D (1999) Lipid peroxidation and tissue damage. in vivo 13:295-310

Nimmo DR, Hansen DJ, Couch JA, Cooley NR, Parrish PR, Lowe JI (1975) Toxicity of Aroclor 1254 and its physiological activity in several estuarine organisms. Arch Environ Contam Toxicol 3:22-39

Nisbit ICT, Sarofim AF (1972) Rates and routes of transport of PCBs in the environment. Environ Health Perspect 1:21-38

Peakall DB, Lincer JL (1970) Polychlorinated biphenyls, another long-life widespread chemical in the environment. BioScience 20:958-964.

Presnell J, Schreibman M (1997) Humason's animal tissue techniques, 5th ed., Johns Hopkins University Press, Baltimore, MD

R Core Team (2013) R: a language and environment for statistical computing. R Foundation for Statistical Computing, Vienna, Austria. [cited 2014 July 7] Available from: http://www.R-project.org/ 
Reasor MJ (1981) Drug-induced lipidosis and the alveolar macrophage. Toxicology 20:133

Reasor MJ (1989) A review of the biology and toxicologic implications of the induction of lysosomal lamellar bodies by drugs. Toxicol Applied Pharmacol 97:47-56

Restum JC, Bursian SJ, Giesy JP, Render JA, Helferich WG, Shipp EB, Verbrugge DA, Aulerich RJ (1998) Multigenerational study of the effects of consumption of PCBcontaminated carp from Saginaw Bay, Lake Huron, on mink. 1. Effects on mink reproduction, kit growth and survival, and selected biological parameters. J Toxicol Environ Health A 54:343-75

Tanabe S (1988) PCB problems in the future: foresight from current knowledge. Environ Pollut 50:5-28.

Tappel AL (1978) Glutathione peroxidase and hydroperoxides. Method Enzymol 52:506513

Teh SJ, Adams SM, Hinton DE (1997) Histopathologic biomarkers in feral freshwater fish populations exposed to different types of contaminant stress. Aquatic Toxicol 37:51-70

Trachootham D, Lu W, Ogasawara MA, Rivera-Del Valle N, Huang P (2008) Redox regulation of cell survival. Antioxidants \& Redox Signaling 10:1343-1374 
US Environmental Protection Agency (U.S. EPA) (1976) Assessment of wastewater management, treatment technology, and associated costs for abatement of PCBs concentrations in industrial effluents, Task II, Final Report. EPA 560/6-76-006

U.S. EPA (2012a) EPA Region V Cleanup Sites accessed on April 20, 2012 at http://www.epa.gov/region5/cleanup/index.htm

U.S. EPA (2012b) National Water Quality Standards accessed on April 20, 2012 at http://water.epa.gov/scitech/swguidance/standards/current/index.cfm

Vega-López A, Galar-Martínez M, Jiménez-Orozco FA, García-Latorre E, DomínguezLópez ML (2007) Gender related differences in the oxidative stress response to PCB exposure in an endangered goodeid fish (Girardinichthys viviparus) Comp Biochem Physiol A 146:672-678

Vega-Lopez A, Jimenez-Orozco FA, Jimenez-Zamudio LA, Garcia-Latorre EA, Dominguez-Lopez ML (2009) Prooxidant and antioxidant sex-linked response and its relationship to mixed oxidase function enzymes in liver of Ameca splendens, an endangered goodeid fish exposed to PCBs. Toxicol Environ Chem 91:315-330

Wu F, Zheng Y, Gao J, Chen S, Wang Z (2014) Induction of oxidative stress and the transcription of genes related to apoptosis in rare minnow (Gobiocypris rarus) larvae with Aroclor 1254 exposure. Ecotoxicol Environ Safety 110:254-260 
Fig. 1. Creek chub sampling locations from eight PCB-contaminated streams: upper and lower Clear Creek (ICS and CC), Conards Branch / Richland Creek (CB), Stouts Creek (SC), Sinking Creek (ABB) in Monroe County, Pleasant Run Creek (PR) in Lawrence County, the Little Mississenewa River (LM1 and LM2) in Randolph County, Elliot Ditch / Wea Creek (ED1 and ED2) in Tippecanoe County, and Shelly Ditch (SD) in Montgomery County, Indiana. Also included are two uncontaminated reference sites: Little Indian Creek (LI), and Brummett Creek (BRUM), Greene and Monroe Counties and a slightly elevated background stream, Burnetts Creek (BC) in Tippecanoe County, Indiana. 


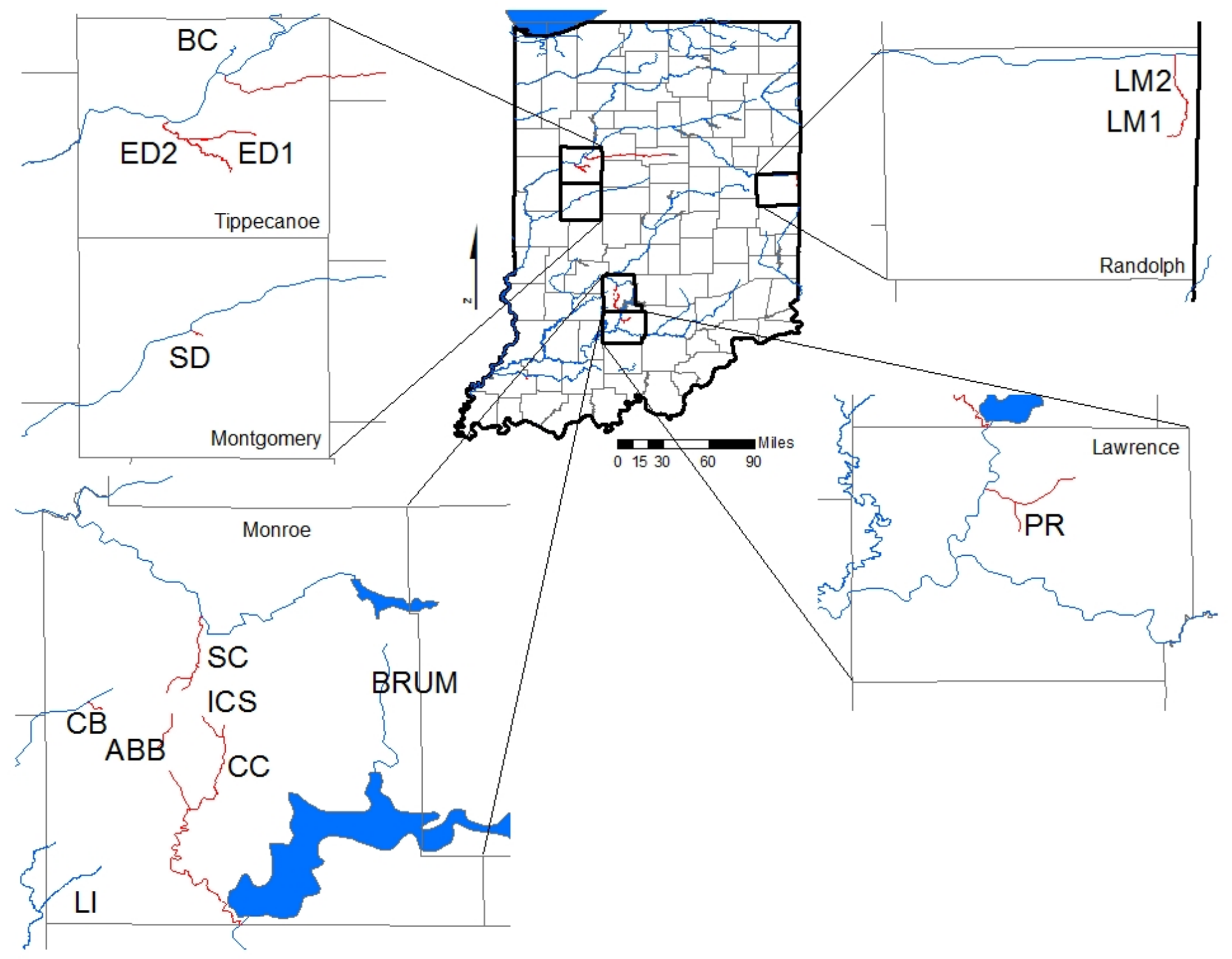


Fig. 2. Examples of the qualitative rating scale used to classify the degree of hepatic lipidosis in creek chubs. Reference site fish (LI and BRUM) are mostly on the left, while fish from a high PCB contaminated stream (ICS) are on the right. The qualitative scale was: $1=$ normal, $2=$ moderate, $3=$ high, and $4=$ severe. 

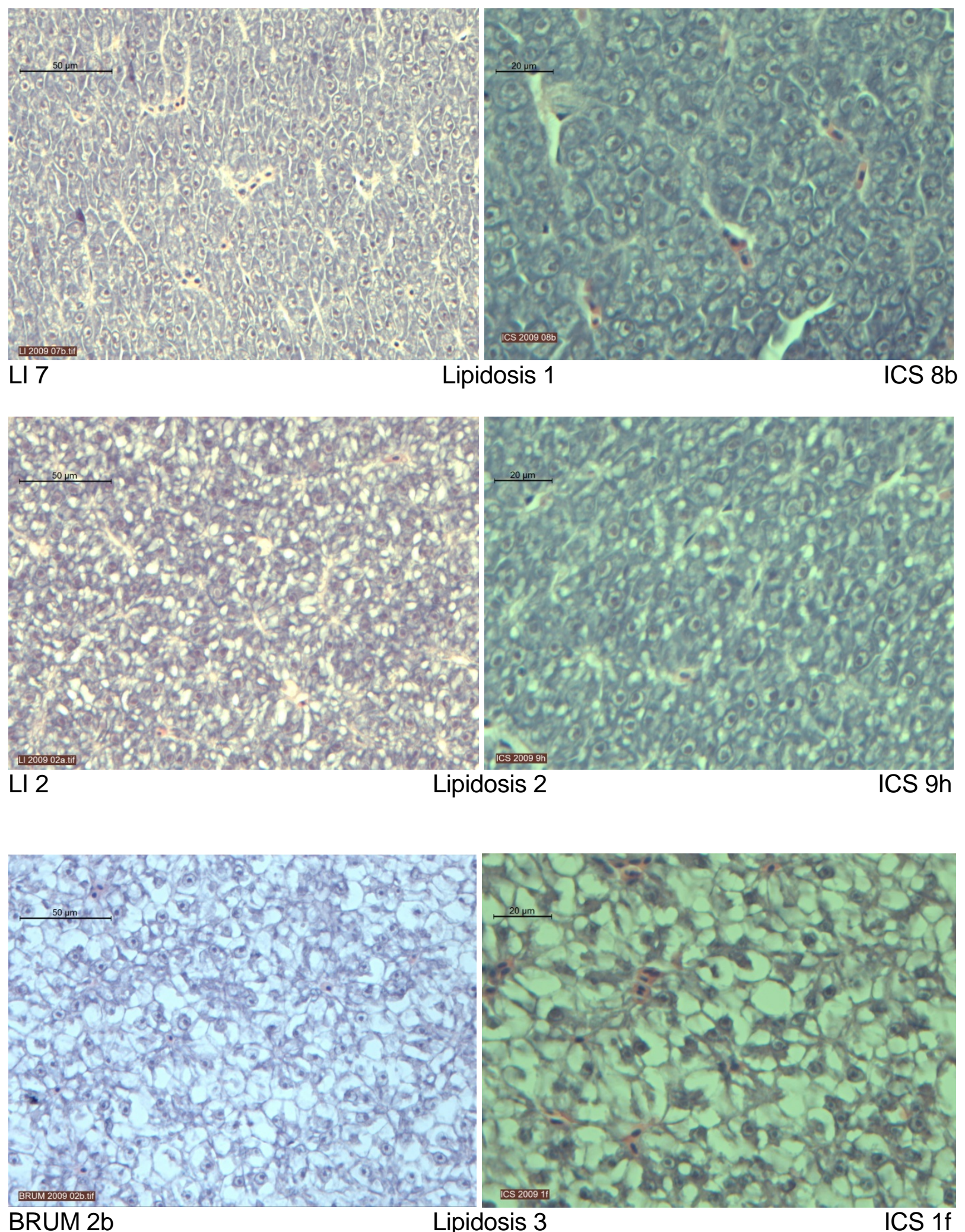

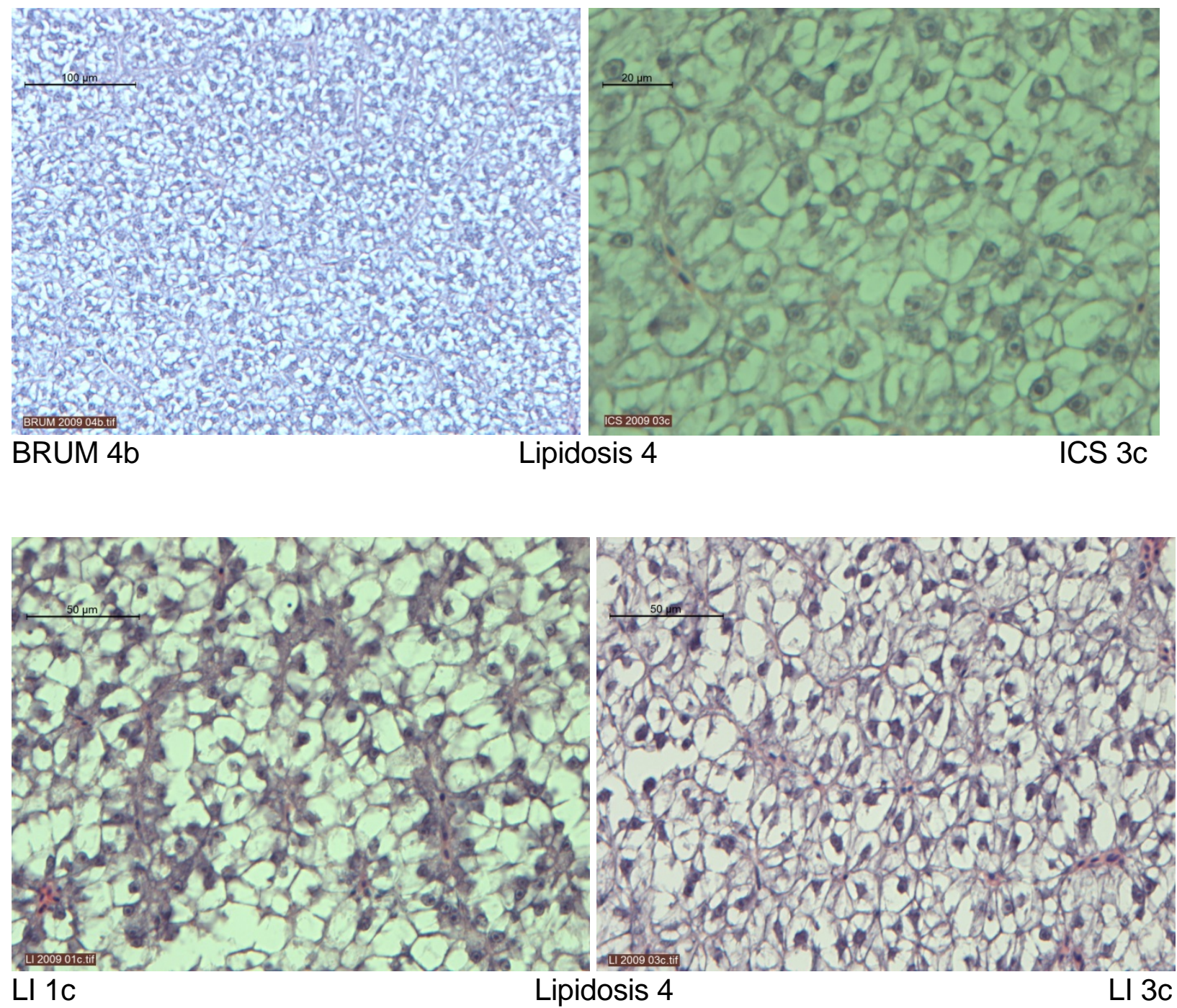
Fig. 3. Anti-oxidant enzyme activity per unit protein for A) catalase (CAT), B) glutathione peroxidase (GPx), C) glutathione reductase (GRx), and D) superoxide dismutase (SOD) versus degree of stream PCB contamination as grouped in Table 1: reference (Ref), low and / or remediated (LowR), medium (Med), and High. Sample size is noted within bars (error bars $=\mathrm{SD}$ ). Bars with different letters are significantly different (Tukey's test; $\alpha<$ 0.05). 
A

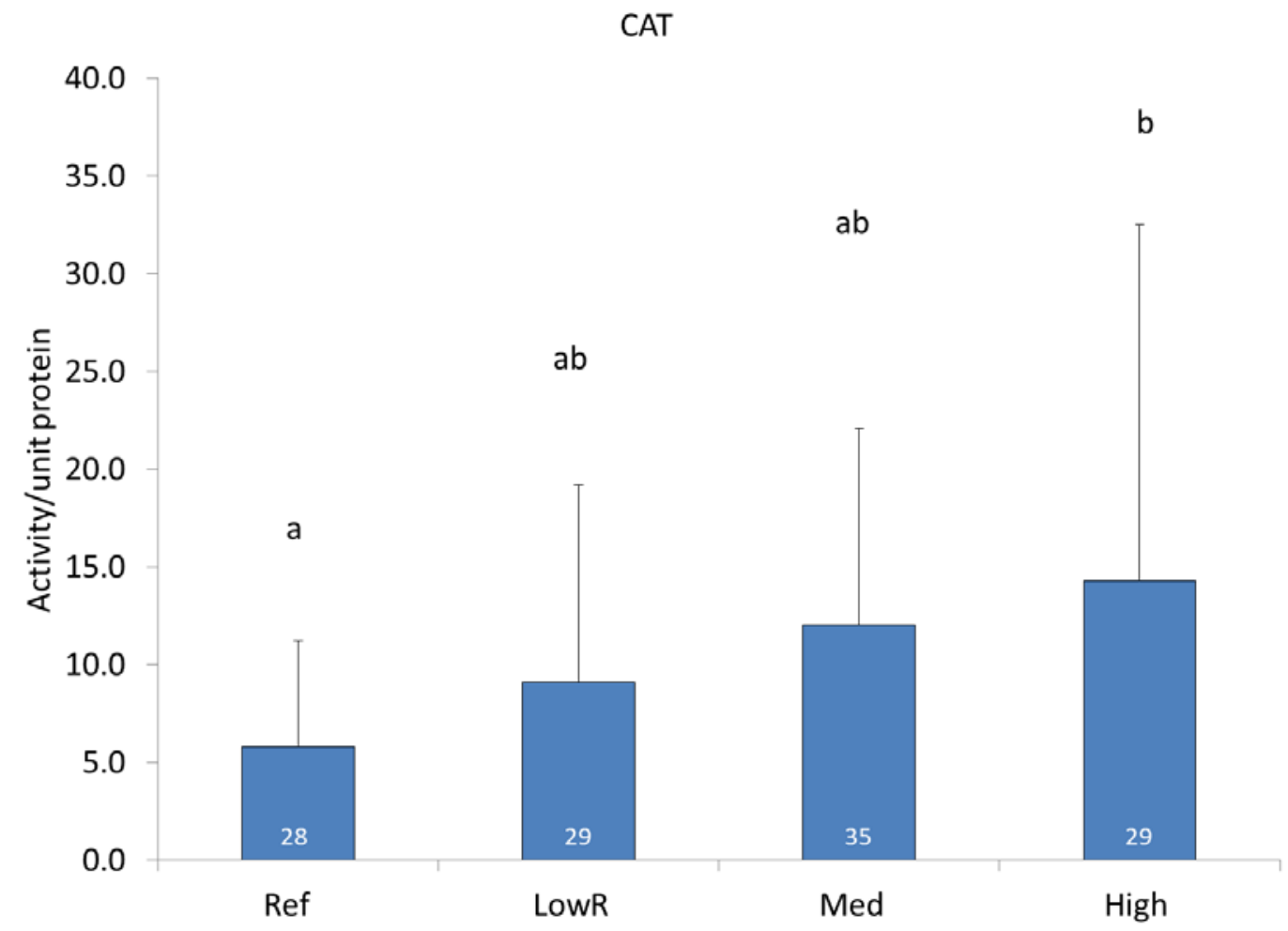

B

GPx

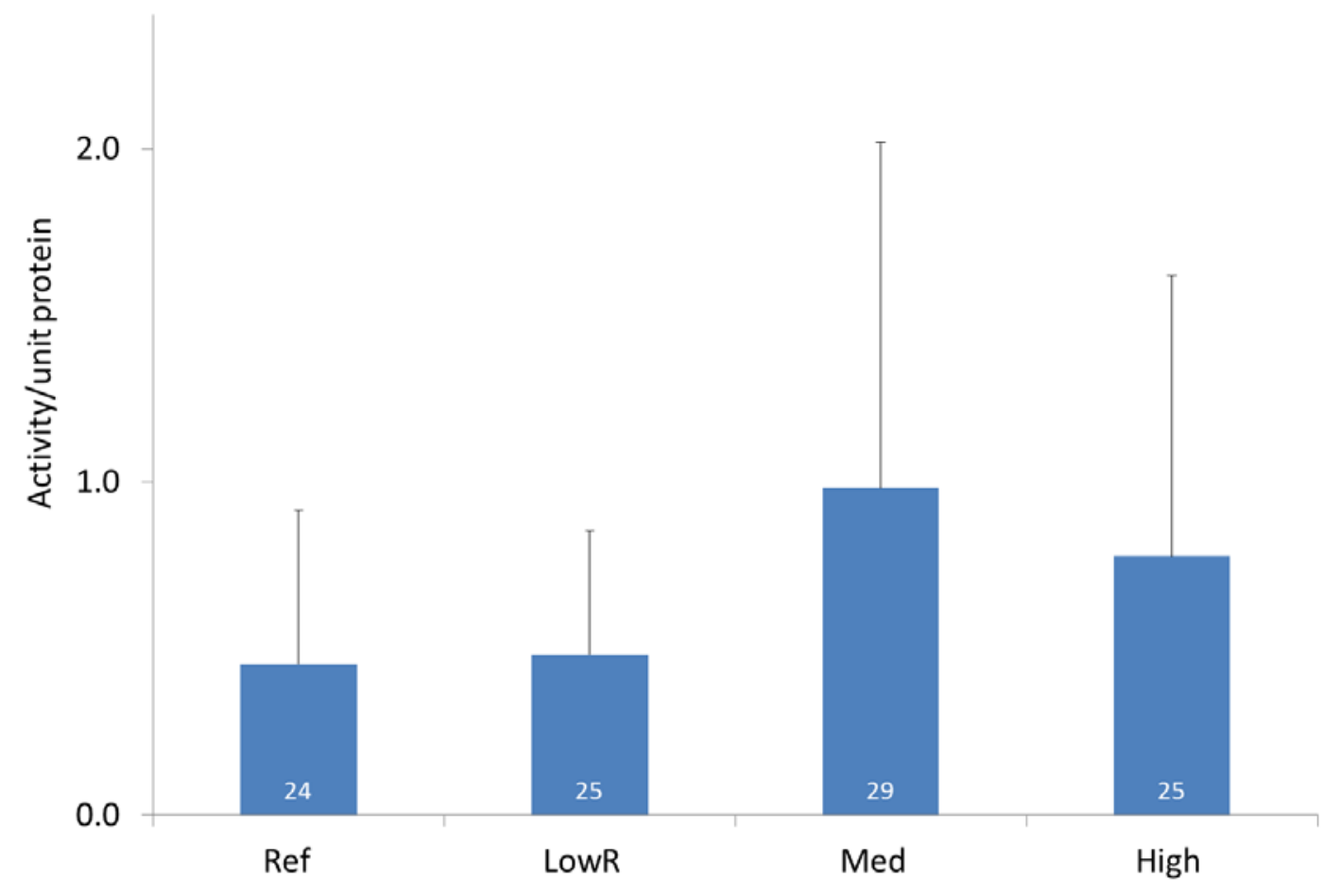


C
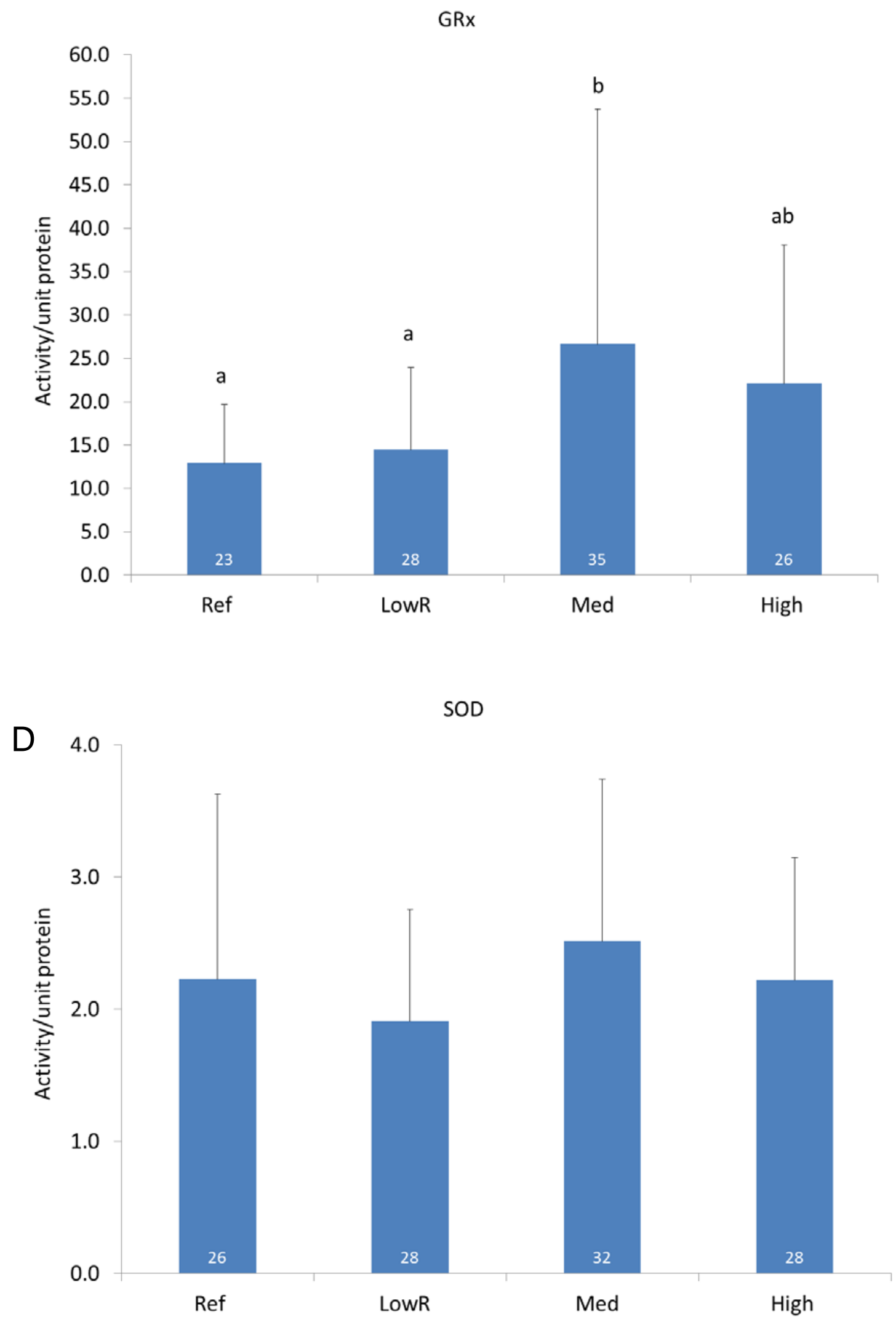
Fig. 4. Anti-oxidant enzyme activity per unit protein for A) catalase (CAT), B) glutathione peroxidase (GPx), C) glutathione reductase (GRx), and D) superoxide dismutase (SOD) versus degree of hepatic lipidosis: normal, moderate (mod), high and severe. Sample size is noted within bars (error bars = SD). Bars with different letters are significantly different (Tukey's test; $\alpha \leq 0.05$ ). 
A

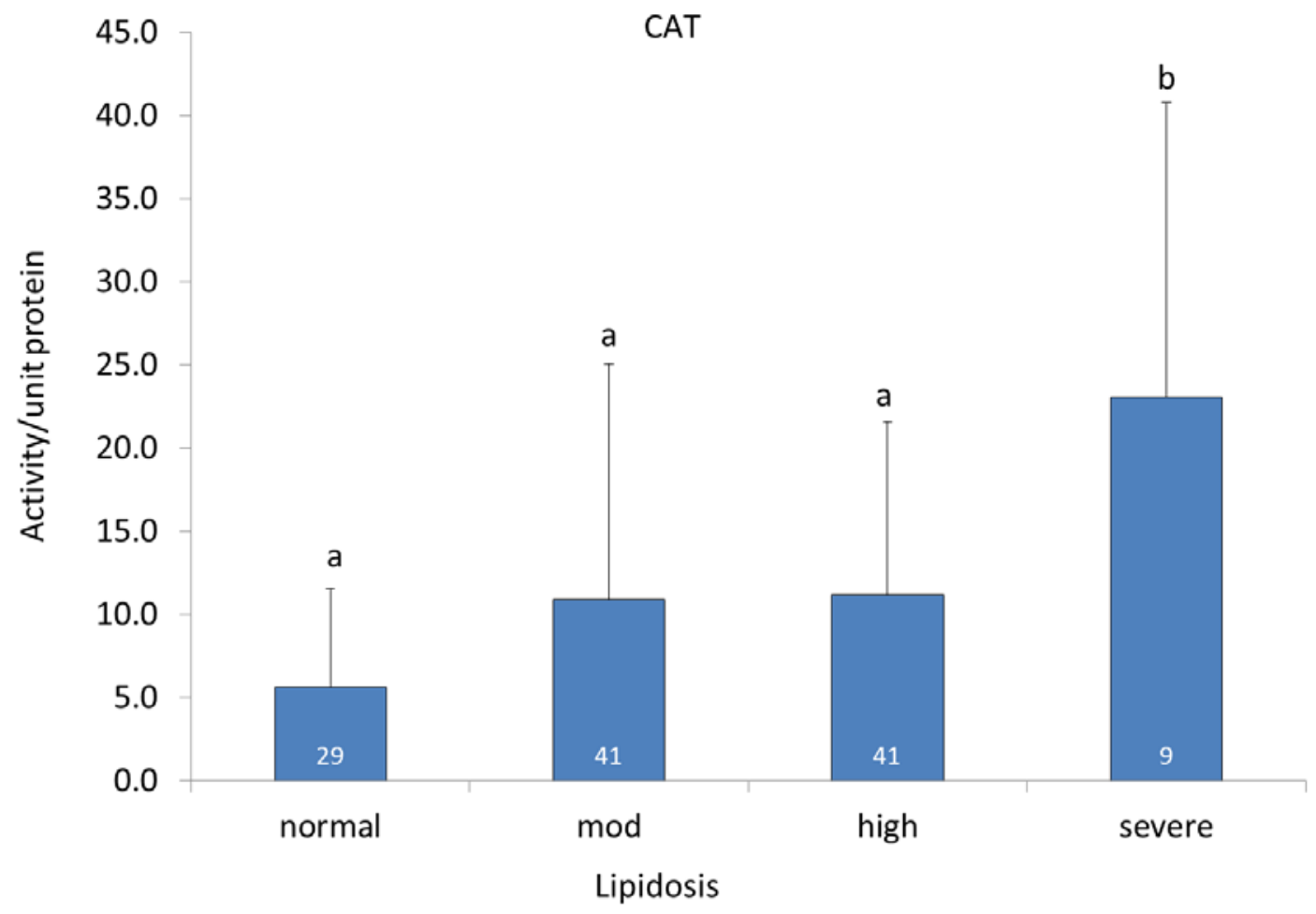

B

GPx

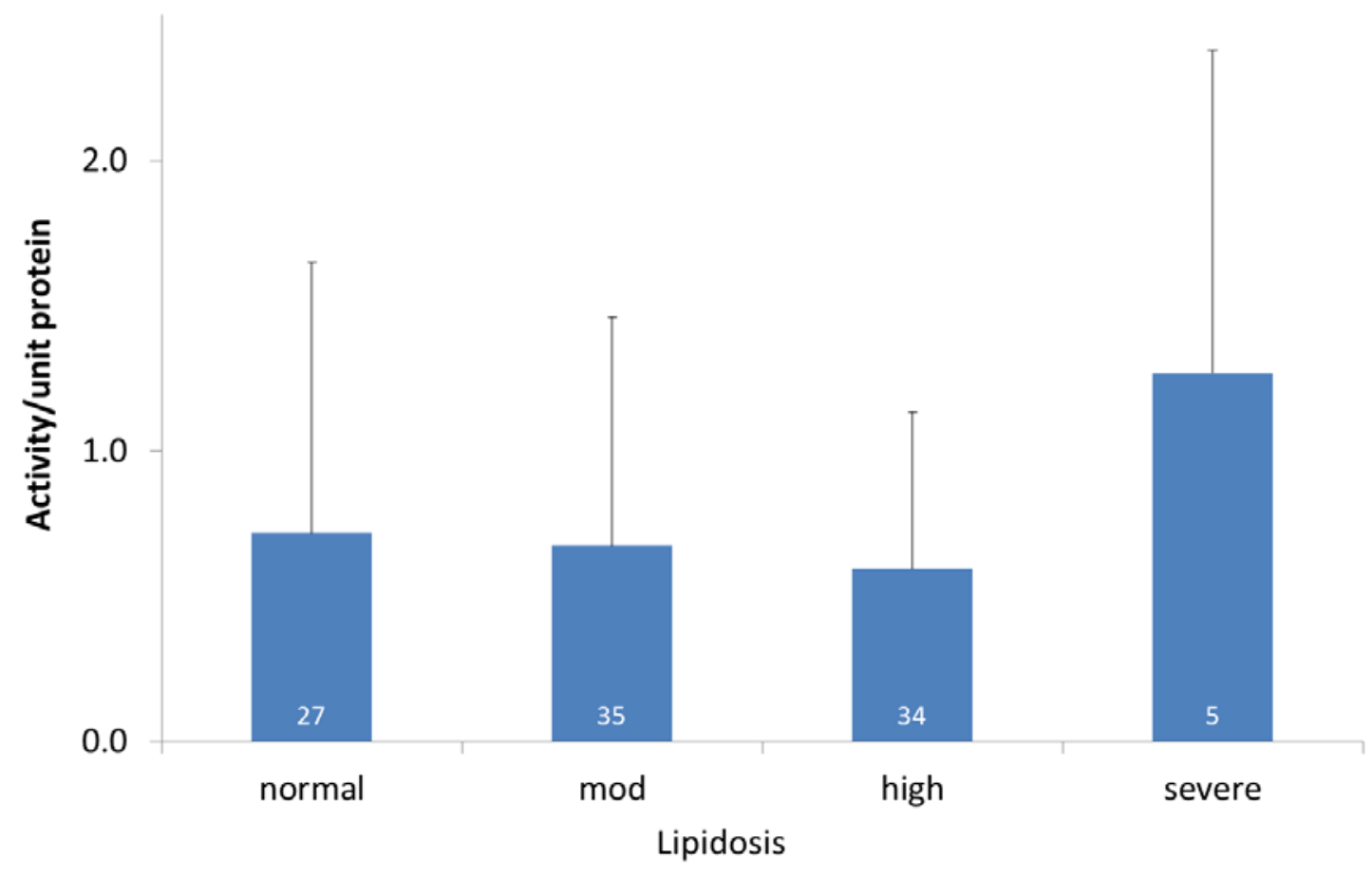


C
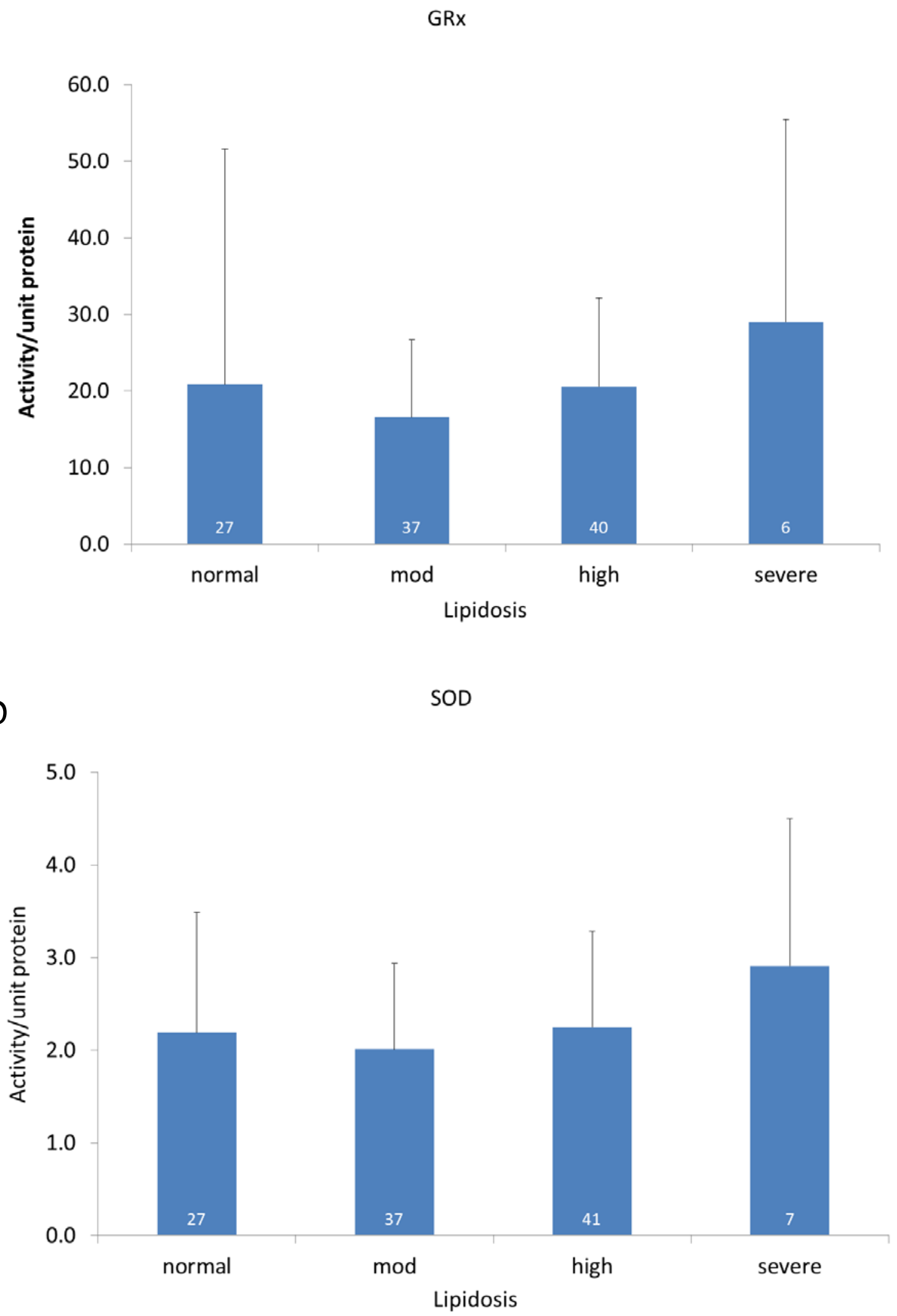
Fig. 5. Relative frequency and degree of hepatic lipidosis for male and female creek chubs from eight PCB-contaminated streams: upper and lower Clear Creek (ICS and CC), Conards Branch / Richland Creek (CB), Stouts Creek (SC), Sinking Creek (ABB) in Monroe County, Pleasant Run Creek (PR) in Lawrence County, the Little Mississenewa River (LM1 and LM2) in Randolph County, Elliot Ditch / Wea Creek (ED1 and ED2) in Tippecanoe County, and Shelly Ditch (SD) in Montgomery County, Indiana. Also included are two uncontaminated reference sites: Little Indian Creek (LI), and Brummett Creek (BRUM), Greene and Monroe Counties and a slightly elevated background stream, Burnetts Creek (BC) in Tippecanoe County, Indiana. Sample sizes are presented in Table 2. 


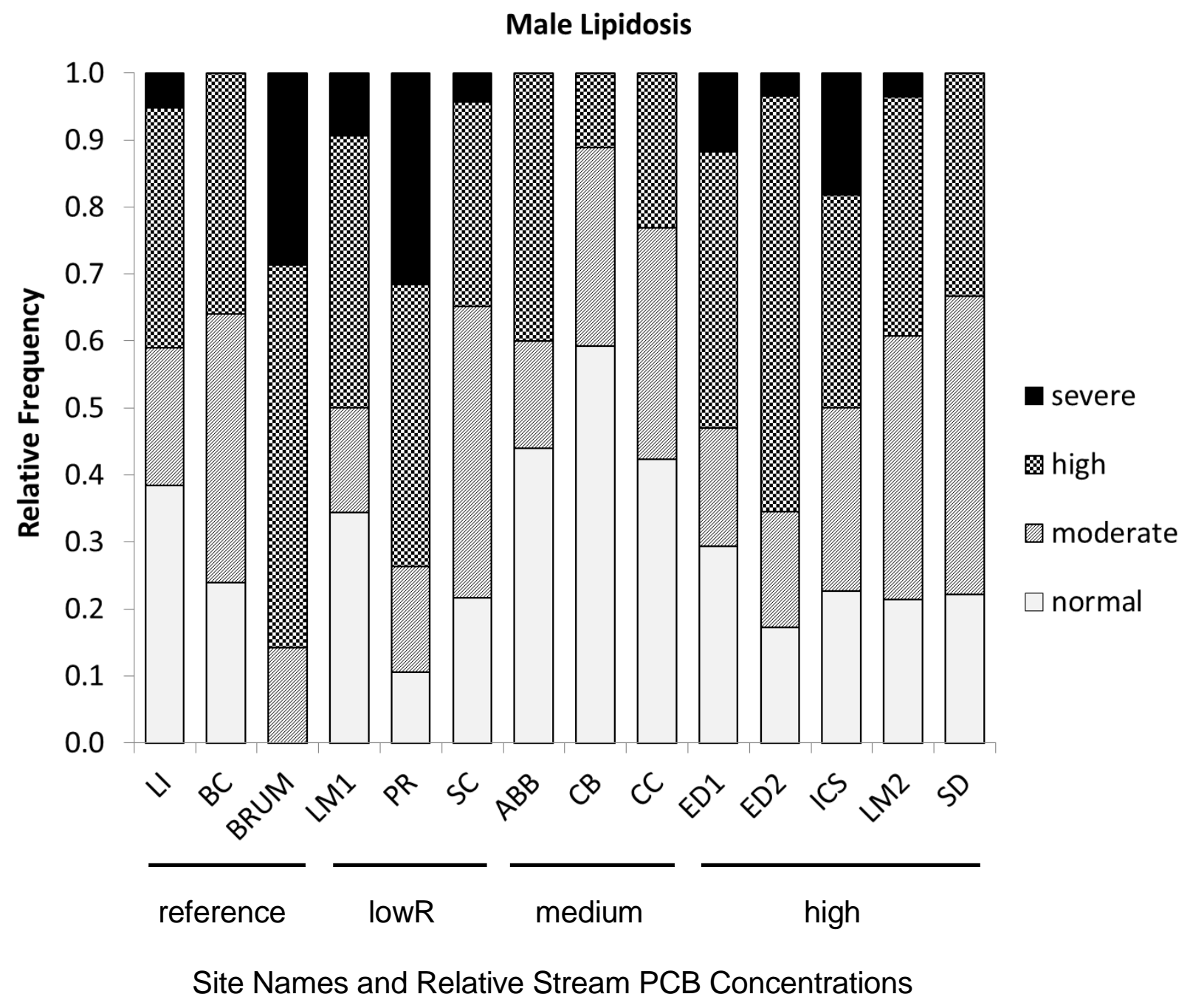




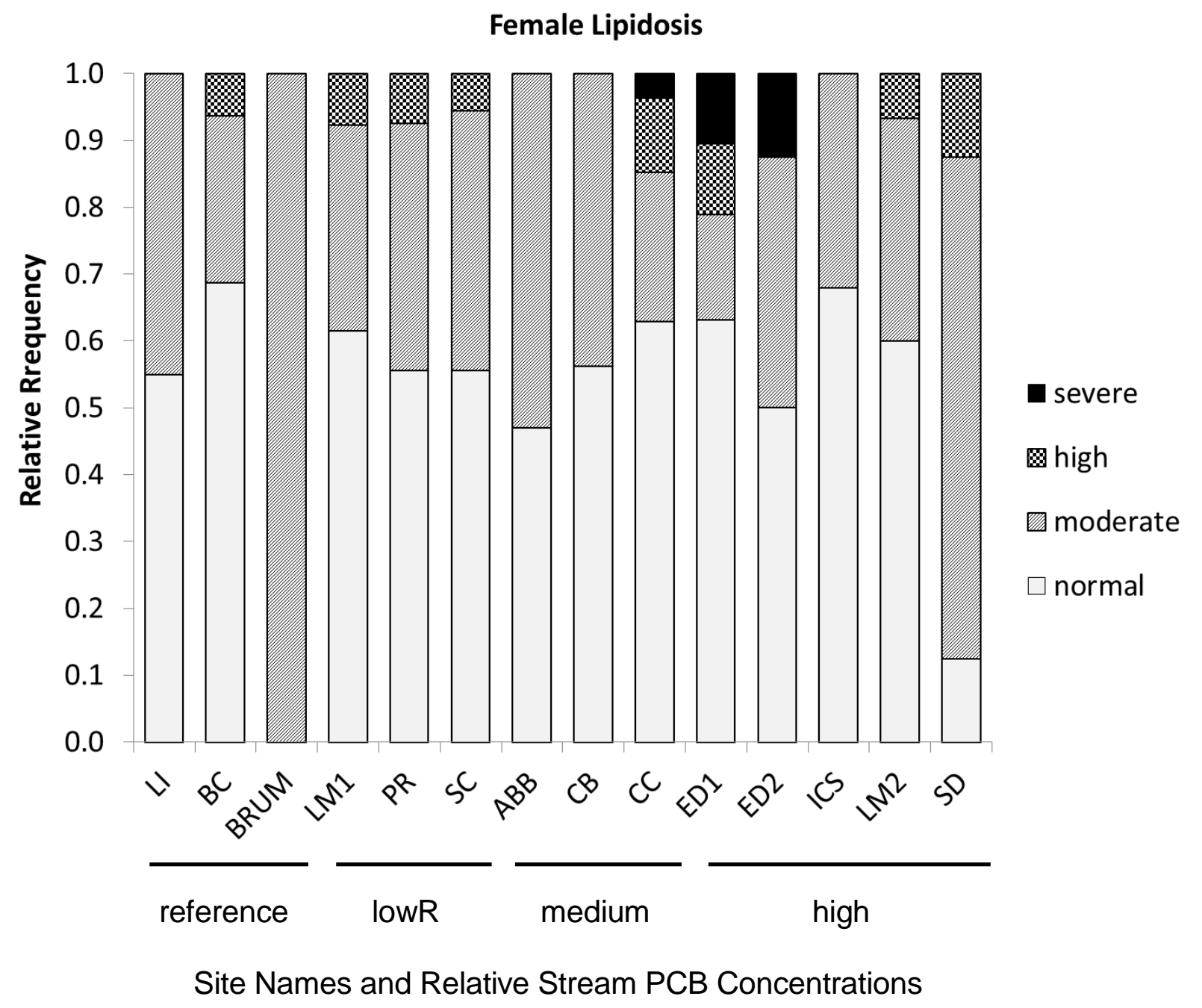


Table 1. Concentrations of PCBs in whole body creek chub samples $(\mu \mathrm{g} / \mathrm{g}$, wet weight) and sediment $(\mu \mathrm{g} / \mathrm{g}$, dry weight) from eight PCB-contaminated streams: Clear Creek (ICS and CC), Conards Branch / Richland Creek (CB), Stouts Creek (SC), Sinking Creek (ABB) in Monroe County, Pleasant Run Creek (PR) in Lawrence County, the Little Mississenewa River (LM1 and LM2) in Randolph County, Elliot Ditch / Wea Creek (ED1 and ED2) in Tippecanoe County, and Shelly Ditch (SD) in Montgomery County, Indiana. Also included are two uncontaminated reference sites: Little Indian Creek (LI), and Brummett Creek (BRUM), Greene and Monroe Counties and a slightly elevated background stream, Burnetts Creek (BC) in Tippecanoe County, Indiana.

\begin{tabular}{|c|c|c|c|c|c|c|c|}
\hline \multirow[b]{2}{*}{ Site } & \multicolumn{3}{|c|}{ Mean whole body PCBs } & \multicolumn{3}{|c|}{ Mean sediment PCBs } & \multirow[b]{2}{*}{$\begin{array}{l}\text { PCB } \\
\text { Grouping }\end{array}$} \\
\hline & $\mu \mathrm{g} / \mathrm{g} \pm \mathrm{sd}$ & $\mathrm{N}$ & $\begin{array}{l}\text { sample } \\
\text { year }\end{array}$ & $\mu \mathrm{g} / \mathrm{g} \pm \mathrm{sd}$ & $\mathrm{N}$ & $\begin{array}{l}\text { sample } \\
\text { year }\end{array}$ & \\
\hline LI & $0.01 \pm 0.004$ & 6 & 1999 & NA & & & reference \\
\hline $\mathrm{BC}$ & $0.10 \pm 0.09$ & 5 & 2003 & NA & & & reference \\
\hline BRUM & $0.014 \pm 0.002$ & 3 & 2010 & 0.006 & 1 & 2010 & reference \\
\hline LM1 & $13.1 \pm 25$ & 12 & 2001 & $27.7 \pm 5.9$ & 4 & 2002 & lowR \\
\hline PR & $4.2 \pm 1.3$ & 3 & 2009 & & & & lowR \\
\hline SC & $0.9 \pm 0.25$ & 5 & 2003 & & & & lowR \\
\hline SC & $1.26 \pm 0.57$ & 7 & 2004 & $0.17 \pm 0.02$ & 3 & 2004 & lowR \\
\hline$A B B$ & $0.94 \pm 0.34$ & 3 & 2004 & NA & & & medium \\
\hline $\mathrm{CB}$ & $12.1 \pm 3.1$ & 8 & 1998 & $1.9 \pm 0.9$ & 5 & 1998 & medium \\
\hline CB & $0.84 \pm 0.33$ & 6 & 2004 & & & & medium \\
\hline $\mathrm{CC}$ & $0.98 \pm 0.68$ & 10 & 2003 & $0.6 \pm 0.1$ & 3 & 1997 & medium \\
\hline ICS & $19.2 \pm 3.2$ & 9 & 1996 & $2.2 \pm 0.03$ & 5 & 1996 & high \\
\hline ICS & $1.8 \pm 1.0$ & 8 & 2004 & & & & high \\
\hline ED1 & $5.6 \pm 2.7$ & 7 & 2001 & $0.69 \pm 0.04$ & 3 & 2011 & high \\
\hline ED2 & $5.3 \pm 2.8$ & 4 & 2001 & $0.53 \pm 0.05$ & 3 & 2011 & high \\
\hline LM1 & $15.0^{-}$ & $1^{\mathrm{a}}$ & 1993 & & & & high \\
\hline LM2 & $24.8 \pm 10.2$ & 10 & 2001 & $3.4 \pm 2.2$ & 5 & 2002 & high \\
\hline LM2 & $5.9 \pm 3.2$ & 4 & 2003 & & & & high \\
\hline PR & $359 \pm 87$ & 6 & 2001 & $7.1 \pm 1.5$ & 14 & 2001 & high \\
\hline SD & $16.9+0.05$ & 3 & 2001 & $2.1+0.6$ & 5 & 2000 & high \\
\hline
\end{tabular}

$\mathrm{N}$ - number of samples; SD - standard deviation; Reference - reference site; lowR - site has been remediated resulting in significant PCB load reductions; medium - moderately contaminated; high - high contamination levels. ${ }^{a}$ - composite of 15. 
Table 2. Creek chub liver histology samples from eight PCB-contaminated streams: upper and lower Clear Creek (ICS and CC), Conard's Branch / Richland Creek (CB), Stouts Creek (SC), Sinking Creek (ABB) in Monroe County, Pleasant Run Creek (PR) in Lawrence County, the Little Mississenewa River (LM1 and LM2) in Randolph County, Elliot Ditch / Wea Creek (ED1 and ED2) in Tippecanoe County, and Shelly Ditch (SD) in Montgomery County, Indiana. Also included are two uncontaminated reference sites: Little Indian Creek (LI), and Brummett Creek (BRUM), Greene and Monroe Counties and a slightly elevated background stream, Burnetts Creek (BC) in Tippecanoe County, Indiana.

\begin{tabular}{|c|c|c|c|c|c|c|c|c|c|c|c|c|c|c|c|c|c|c|c|c|c|c|c|c|c|c|c|c|}
\hline & \multicolumn{2}{|c|}{ ABB } & \multicolumn{2}{|c|}{$B C$} & \multicolumn{2}{|c|}{ BRUM } & \multicolumn{2}{|c|}{ CB } & \multicolumn{2}{|c|}{ ICS } & \multicolumn{2}{|c|}{$\mathrm{CC}$} & \multicolumn{2}{|c|}{ ED1 } & \multicolumn{2}{|c|}{ ED2 } & \multicolumn{2}{|c|}{$\mathrm{LI}$} & \multicolumn{2}{|c|}{ LM1 } & \multicolumn{2}{|c|}{ LM2 } & \multicolumn{2}{|c|}{ PR } & \multicolumn{2}{|c|}{$\mathrm{SC}$} & \multicolumn{2}{|c|}{ SD } \\
\hline & $M$ & $\mathrm{~F}$ & $M$ & $\mathrm{~F}$ & $M$ & $\mathrm{~F}$ & $M$ & $\mathrm{~F}$ & $M$ & $\mathrm{~F}$ & $M$ & $\mathrm{~F}$ & $M$ & $\mathrm{~F}$ & $M$ & $\mathrm{~F}$ & $M$ & $\mathrm{~F}$ & $M$ & $\mathrm{~F}$ & $M$ & $\mathrm{~F}$ & $M$ & $\mathrm{~F}$ & $M$ & $\mathrm{~F}$ & $M$ & $\mathrm{~F}$ \\
\hline January & & & & & & & 3 & 3 & 8 & 5 & 3 & 3 & & & & & 10 & 2 & & & & & & & & & & \\
\hline February & & & & & & & & & 4 & 9 & 11 & 6 & & & 1 & 1 & 2 & 2 & & & & 1 & 1 & 2 & 2 & 1 & 1 & \\
\hline March & 13 & 4 & 15 & 14 & 7 & 3 & 7 & 2 & & & & & 4 & 2 & 3 & 2 & & & 7 & 1 & 1 & & 1 & 5 & 4 & 1 & 5 & 1 \\
\hline April & & & 2 & & & & & & 7 & 3 & 5 & 5 & 4 & 9 & 13 & 5 & 16 & 11 & 10 & 5 & 8 & 7 & 1 & 4 & 10 & 6 & 3 & \\
\hline May & & & 7 & 1 & & & & & & & & & 2 & 4 & 5 & 1 & & & 3 & 3 & 3 & 2 & & 7 & 8 & 5 & 3 & 3 \\
\hline June & & & & & & & & & & & & & 3 & 3 & 2 & 2 & & & 4 & 1 & 3 & 2 & & 2 & & & 9 & 1 \\
\hline July & & & 3 & 3 & & & & & & & & 1 & & & & & & & & & & & & & & & & \\
\hline August & & & 4 & 1 & & & & & & & 1 & 1 & 1 & 1 & 1 & 2 & & & & & & & 4 & 1 & & & 3 & 1 \\
\hline September & 13 & 14 & & & & & 9 & 3 & & & & & & & & & & & 5 & 1 & 6 & 1 & & 1 & & & & \\
\hline October & & & & & & & 3 & 4 & 2 & 8 & 7 & 10 & 2 & & 3 & 1 & 3 & 1 & 1 & & 9 & & 1 & 1 & & & 4 & 2 \\
\hline November & & & & & & & 3 & 2 & & & & & & & 2 & & 4 & 2 & 2 & 1 & & 1 & 2 & & & 1 & & \\
\hline December & & & 2 & & & & & 1 & & & & & 1 & 1 & 1 & 1 & 4 & 2 & & & & & 1 & 1 & 2 & 1 & & \\
\hline subtotal & 26 & 18 & 33 & 19 & 7 & 3 & 25 & 15 & 21 & 25 & 27 & 26 & 17 & 20 & 31 & 15 & 39 & 20 & 32 & 12 & 30 & 14 & 11 & 24 & 26 & 15 & 28 & 8 \\
\hline total & & & & & & & & & & & & & 3 & & & & & & & & & & & & & & & \\
\hline
\end{tabular}


Table 3. Mean male hepatic oxidative stress enzymes [ $\pm \mathrm{SD},(\mathrm{N})]$ in creek chubs from seven PCB-contaminated streams: Clear Creek (ICS and CC), Conards Branch / Richland Creek (CB), Stouts Creek (SC), Sinking Creek (ABB) in Monroe County, Pleasant Run Creek (PR) in Lawrence County, the Little Mississenewa River (LM1 and LM2) in Randolph County, and Elliot Ditch / Wea Creek (ED2) in Tippecanoe County, Indiana. Also included are two uncontaminated reference sites: Little Indian Creek (LI), and Brummett Creek (BRUM), Greene and Monroe Counties and a slightly elevated background stream, Burnetts Creek (BC) in Tippecanoe County, Indiana.

\begin{tabular}{|c|c|c|c|c|c|c|}
\hline Site & PCB level & GPx & GRx & CAT & SOD & Lipidosis Score \\
\hline $\mathrm{LI}$ & reference & 0.09 & $11.3 \pm 4.6(2) a b$ & $8.8 \pm 9.6(3)$ & $3.61 \pm 2.84(2)$ & $3.33 \pm 1.15(3)$ \\
\hline Brum & reference & $0.38 \pm 0.37(6)$ & $11.0 \pm 7.3(6) a$ & $8.3 \pm 7.1(7)$ & $1.85 \pm 0.51(7)$ & $3.14 \pm 0.69(7)$ \\
\hline$B C$ & reference & $0.40 \pm 0.05(3)$ & $21.3 \pm 7.0(3) a b$ & $4.1 \pm 4.4(3)$ & $1.87 \pm 1.40(3)$ & $2.33 \pm 0.58(3)$ \\
\hline LM1 & LowR & $0.39 \pm 0.21(6)$ & $13.2 \pm 7.8(6) a$ & $10.0 \pm 11.0(6)$ & $1.88 \pm 0.38(6)$ & $2.29 \pm 0.95(7)$ \\
\hline PR & LowR & $0.74 \pm 0.67(5)$ & $21.8 \pm 15.8(6) a b$ & $13.4 \pm 14.3(7)$ & $1.72 \pm 1.15(7)$ & $3.00 \pm 0.58(5)$ \\
\hline SC & LowR & $0.45 \pm 0.32(9)$ & $12.1 \pm 6.3(9) a$ & $9.5 \pm 8.9(9)$ & $2.05 \pm 0.43(9)$ & $2.25 \pm 0.71(8)$ \\
\hline $\mathrm{ABB}$ & Medium & $1.01 \pm 0.88(10)$ & $23.9 \pm 10.3(12) a b$ & $12.9 \pm 10.1(12)$ & $1.01 \pm 0.88(10)$ & $2.83 \pm 0.39(12)$ \\
\hline CB & Medium & $0.51 \pm 0.26$ & $19.3 \pm 10.5(6) a b$ & $13.9 \pm 13.3(6)$ & $2.40 \pm 1.61$ & $1.57 \pm 0.53$ \\
\hline $\mathrm{CC}$ & Medium & $1.07 \pm 1.01(4)$ & $22.6 \pm 10.9(7) a b$ & $19.7 \pm 9.9(7)$ & $3.55 \pm 1.41(7)$ & $2.25 \pm 0.50$ \\
\hline ED2 & High & $0.43 \pm 0.40$ & $15.9 \pm 9.4(6) a b$ & $13.9 \pm 9.8(6)$ & $1.84 \pm 0.85(6)$ & $2.50 \pm 0.84$ \\
\hline ICS & High & $1.17 \pm 0.96$ & $37.3 \pm 21.9(7) b$ & $23.4 \pm 19.8(7)$ & $2.88 \pm 1.17(7)$ & $3.29 \pm 0.49$ \\
\hline LM2 & High & $0.69 \pm 0.68$ & $21.3 \pm 6.3(5) a b$ & $10.0 \pm 10.4(5)$ & $2.10 \pm 0.88(5)$ & $3.20 \pm 0.45$ \\
\hline
\end{tabular}

PCB levels: Reference - reference site; lowR - site has been remediated resulting in significant PCB load reductions; medium - moderately contaminated; high - high contamination levels. GPx - glutathione peroxidase; GRx - glutathione reductase; CAT - catalase; SOD - superoxide dismutase; SD - standard deviation; N; number of animals. Means with different letters are significantly different at $\alpha<0.05$. 
Table 4. Mean female hepatic oxidative stress enzymes [ $\pm \mathrm{SD},(\mathrm{N})]$ in creek chubs from seven PCB-contaminated streams: Clear Creek (ICS and CC), Conards Branch / Richland Creek (CB), Stouts Creek (SC), Sinking Creek (ABB) in Monroe County, Pleasant Run Creek (PR) in Lawrence County, the Little Mississenewa River (LM1 and LM2) in Randolph County, and Elliot Ditch / Wea Creek (ED2) in Tippecanoe County, Indiana. Also included are two uncontaminated reference sites: Little Indian Creek (LI), and Brummett Creek (BRUM), Greene and Monroe Counties and a slightly elevated background stream, Burnetts Creek (BC) in Tippecanoe County, Indiana.

\begin{tabular}{|c|c|c|c|c|c|c|}
\hline Site & PCB level & GPx & GRx & CAT & SOD & Lipidosis Score \\
\hline$\overline{\mathrm{LI}}$ & reference & $0.55 \pm 0.35(7)$ & $13.6 \pm 5.3(6)$ & $4.7 \pm 3.3(7)$ & $2.16 \pm 1.45(7)$ & $1.43 \pm 0.53(7)$ \\
\hline Brum & reference & 0.06 & $7.3 \pm 4.7(1)$ & $7.2 \pm 6.6(2)$ & $2.02 \pm 1.19(2)$ & $2.00 \pm 0.00(2)$ \\
\hline $\mathrm{BC}$ & reference & $0.61 \pm 0.77(6)$ & $12.0 \pm 7.1(4)$ & $3.1 \pm 1.8(6)$ & $2.62 \pm 1.97(5)$ & $1.33 \pm 0.52(6)$ \\
\hline LM1 & LowR & $0.20 \pm 0.05(2)$ & $7.6 \pm 2.0(2)$ & $2.2 \pm 1.6(2)$ & $1.38 \pm 0.07(2)$ & $1.00 \pm 0.00(2)$ \\
\hline PR & LowR & $0.45 \pm 0.06(2)$ & $12.7 \pm 3.5(3)$ & $3.7 \pm 2.3(3)$ & $1.49 \pm 0.91(3)$ & $1.33 \pm 0.58$ \\
\hline SC & LowR & $0.56 \pm 0.01(2)$ & $16.6 \pm 1.4(2)$ & $4.9 \pm 2.0(2)$ & 4.36 & $1.50 \pm 0.71(2)$ \\
\hline ABB & Medium & $2.42 \pm 3.17(2)$ & $16.2 \pm 0.6(2)$ & $3.7 \pm 2.3(3)$ & $1.65 \pm 0.06(2)$ & $1.67 \pm 0.58(3)$ \\
\hline $\mathrm{CB}$ & Medium & $0.72 \pm 0.92(3)$ & $24.6 \pm 13.1(3)$ & $4.9 \pm 2.4(3)$ & $3.29 \pm 1.27(3)$ & $1.67 \pm 0.58(3)$ \\
\hline $\mathrm{CC}$ & Medium & $0.92 \pm 0.79(5)$ & $23.5 \pm 13.9(6)$ & $9.7 \pm 7.9(6)$ & $1.80 \pm 0.80(6)$ & $1.33 \pm 0.52(6)$ \\
\hline ED2 & High & $0.33 \pm 0.15$ & $18.7 \pm 8.8(3)$ & $3.8 \pm 0.8(3)$ & $2.37 \pm 0.54(3)$ & $1.67 \pm 0.58(3)$ \\
\hline ICS & High & 1.92 & 24.9 & $6.6 \pm 3.6(5)$ & $2.29 \pm 0.82(3)$ & $1.67 \pm 0.58(3)$ \\
\hline LM2 & High & $0.93 \pm 1.33(5)$ & $7.8 \pm 2.8(4)$ & $17.3 \pm 34.4(5)$ & $1.59 \pm 0.60(4)$ & $1.80 \pm 0.45(5)$ \\
\hline
\end{tabular}

PCB levels: Reference - reference site; lowR - site has been remediated resulting in significant PCB load reductions; medium - moderately contaminated; high - high contamination levels. GPx - glutathione peroxidase; GRx - glutathione reductase; CAT - catalase; SOD - superoxide dismutase; SD - standard deviation; N; number of animals. 
Chapter 3 -- Reproductive biology of creek chub (Semotilus atromaculatus) (Mitchill) from PCB-contaminated streams in Indiana

\section{Abstract}

We examined creek chubs from two PCB contaminated streams (Clear Creek and Richland Creek) at three locations and a reference stream (Little Indian Creek) to determine if reproductive measures were correlated with instream PCB exposure. We captured approximately $5-15$ fish weekly during the spring spawning season and monthly all other months of the year. Differences in synchronization of male and female sexual maturation was observed at PCB-contaminated streams. By mid-May at the reference site all spawning was complete. We observed no reference females with maturing or ripe ova after mid-May, whereas at our PCB-contaminated locations several females were found carrying deteriorating ova in various stages of maturity as late as July. In Clear Creek, we observed females with significantly reduced oocyte size and delays in ovary maturation (as evidenced by oocyte size and coloration). Total fecundity was reduced at the PCB-contaminated sites. Many males exhibited reductions / aberrations in seasonal testes maturation and nuptial tubercle development at the PCBcontaminated sites. We observed significant differences seasonally in ovary weight and fecundity between the reference site and PCB-contaminated sites. Plasma estrogen $\left(E_{2}\right)$ was also reduced in females from the PCB-contaminated sites. Testosterone to estrogen ratios were elevated in females at the PCB-contaminated streams, a possible indicator of PCB-induced neuroendocrine disruption. 


\section{Introduction}

The effects of polychlorinated biphenyls (PCBs) on reproductive biology of fish have been studied extensively. Successful reproduction in fish is dependent upon many organs and systems regulated by a healthy endocrine system (Mommsen and Walsh 1988; Thomas 1999). Creek chub sexual maturity typically begins for males by 2 years of age and 1+ years for females. Creek chubs are iteroparous; they undergo a seasonal reproductive cycle in which gonadal recrudescence (increase in size and maturity) begins in the fall and lasts for several months. In very late winter / early spring, final maturation occurs rapidly (over several days) and spawning follows shortly thereafter. Post spawning, gonads regress for a latency period of several months before beginning the process again. They are annual total spawners (Ross 1977) with synchronous development. This seasonal cycle of recrudescence, maturation, spawning and latency is altered by PCBs. The disruption or alteration of the controlling endocrine system can result in reduced or failed reproduction. Adverse impacts caused by PCBs have been observed at many key locations within this complex reproductive system. Effects include: decreased blood levels of estrogen (E2) in females (Sivarajah et al. 1978a, 1978b; Thomas 1989; Casillas et al. 1991), reduced pituitary gonadotropin (Gn) levels in females (Thomas 1989; Black et al. 1998a), decreased serotonin and dopamine blood levels in females (Khan and Thomas 1996, 1997), delays in sexual maturation (Bengtsson 1980; Chen et al. 1986; Thomas 1989; Monosson et al. 1994; Khan and Thomas 1996), decreased testes size (Freeman and Idler 1975; Sangalang et al. 1981; Freeman et al. 1982; Khan and Thomas 1996), reduced testosterone $(\mathrm{T})$ levels in males (Sivarajah et al. 1978a, 1978b; Khan and 
Thomas 1997), reduced numbers of eggs produced (Black et al. 1998b; Daouk et al. 2011), failed ovulation (Black et al. 1998a), reduction in egg quality as represented by reduced size of eggs (Sivarajah et al. 1978b; Mac and Seelye 1981; Black et al. 1988; Monosson et al. 1994; Thomas 1999), the failure of eggs to hatch (Halter and Johnson 1974; Freeman and Idler 1975; Spies and Rice 1988) and the failure of fry to survive (Hansen et al. 1973; Orn et al. 1998) or for spawning to occur (Nebeker et al. 1974; Bengtsson 1980). An additional result of reduced or failed spawning can be an increased proportion of atretric ova (Johnson et al. 1988; Black et al. 1998b) in species that spawn over multiple years. Histological examination showed increased oocyte atresia associated with increasing PCB-contamination (Cross and Hose 1988; Collier et al. 1992; Daouk et al. 2011). Increased oocyte atresia correlated with premature female mortality (Black et al. 1998b), and decreased female survivorship (Henshel et al. 2006). It was speculated that this mortality was an energetics issue and correlated with the dioxin-equivalent fraction of PCBs (Black et al. 1998a).

We initiated a comprehensive investigation of creek chubs (Semotilus atromaculatus) because it is common throughout Indiana and is known to be present in many streams that are highly contaminated with PCBs (Chapter 1 ). In this study, we assess whether or not adverse impacts from PCB exposure can be observed under field conditions on the reproductive biology of the creek chub. Specifically, we examine creek chubs from PCB-contaminated streams and reference sites to determine reproductive status including secondary sexual characteristics, testes and ovary status and condition, fecundity, gonadal histology, plasma sex steroids and vitellogenin (Vtg). 


\section{Methods}

This study was divided into 2 components. The first was a comprehensive investigation (primary study areas) of several reproduction metrics of creek chubs at a reference site (Little Indian Creek - LI), and 3 PCB-contaminated sites (upper Clear Creek - ICS; lower Clear Creek - CC; and Conards Branch / Richland Creek - CB) over the full annual cycle during the years $1999-2005$. The follow-up study consisted of a survey of these 4 primary sites and 8 additional sites (1 reference and 7 PCB-contaminated sites) during a few weeks in the spring 2009 spawning season. These additional sites have a range of PCB contamination: the additional reference site (BRUM); three PCB-contaminated, but recently remediated streams, Stouts Creek (SC), Little Mississenewa River headwaters (LM1) and Pleasant Run Creek (PR); two with high PCB concentrations, downstream Little Mississenewa River (LM2) and downstream Elliot Ditch (ED2); and a slightly elevated background stream Burnett's Creek (BC) (Table 1; see also Chapter 1 and Chapter 2 for more details).

\section{Primary study areas}

Lemon Lane Landfill (LL) and Neal's Landfill (NL) are National Priorities List (Superfund) sites located in Monroe County, Indiana. We collected creek chubs from Clear Creek at 2 locations (ICS and CC) downstream of the primary discharge of PCB-contaminated groundwater emanating from LL. The ICS site (drainage area $6.0 \mathrm{~km}^{2}$ ) was located 1,400 $\mathrm{m}$ downstream and the $\mathrm{CC}$ site (drainage area $16.3 \mathrm{~km}^{2}$ ) was located $3,100 \mathrm{~m}$ downstream of the LL discharge springs. We also sampled Conards Branch / Richland 
Creek (CB) (drainage area $8.0 \mathrm{~km}^{2}$ ) approximately $800 \mathrm{~m}$ downstream of the primary discharge of PCB-contaminated groundwater emanating from NL. The reference site, LI, was just upstream of its confluence with Indian Creek (drainage area $27.4 \mathrm{~km}^{2}$ ). All 4 sites are in the White River drainage, Monroe County, Indiana (Fig. 1). Concentrations of PCBs in fish and/or sediments have been well studied at these sites (ISDH 1994). Polychlorinated biphenyls are the only significant bioaccumulating contaminant of concern at these study sites and there are no waste water effluents entering the waterways upstream of these study sites (ISDH 1994). Only very low levels of PCBs are found in fish at LI, representative of background conditions for southwestern Indiana. More information on these study sites and creek chub PCB chemistries is available (Henshel et al. 2006; Chapter 1).

Monthly collection of 5-15 individuals were conducted between April 1999 and April 2000, 2001, and $2004-2005$ at all sites using a battery back-pack pulsed-DC electrofishing unit (model ABP-3-450V, ETS Electrofishing LLC, Verona, WI). We collected fish weekly during reproductive time (March to May) periods and monthly during non-reproductive periods (June to February). Fish were preserved by immersion fixation in $10 \%$ phosphate buffered formalin for future laboratory analysis. During each sampling event, an effort was made to look for signs of spawning activity such as the presence of males in breeding condition (coloration and presence of nuptial tubercles), males defending territories, presence of nests, and presence of young of the year as seasonally appropriate. These observations were not quantified but activities and observations were noted. Once back at the laboratory, preserved creek chubs were rinsed in tap water, blotted dry, and weighed to the nearest $0.1 \mu \mathrm{g}$. Both gonads of all fish were evaluated for 
gross abnormalities and weighed separately to the nearest $0.1 \mu \mathrm{g}$. Residual weights were recorded after each weight to account for differences in evaporation.

\section{Female reproductive condition and fecundity estimation}

From the recorded weights, a gonadal somatic index (GSI) was calculated for females $\geq$ 12 months old by dividing gonadal mass by whole body mass. Reproductive condition of females was examined visually to classify ovaries into one of four developmental stages following Heins and Rabito (1986) (see also: Phillips et al. 2007; Holmes et al. 2010; Stallsmith et al. 2015). Latent (LA) or phase 0 ooyctes are non-spherical, small, translucent, clear to opaque or white ooyctes and generally $<0.2 \mathrm{~mm}$. Early maturing (EM) (phase I) (oocytes) ova are opaque, white, and non-spherical, usually $0.2-0.6$ $\mathrm{mm}$. Late mature (LM) Phase II ova are larger, homogeneous size and uniform pale yellow, spherical, and translucent, approximately $0.6-0.9 \mathrm{~mm}$. Mature (MA) phase III ova were very large, translucent yellow and generally $>1.0 \mathrm{~mm}$. Ovulated Ripe (RE) ova were amber and generally $>1.4 \mathrm{~mm}$. Our classification was consistent with the total synchronous organization of the ovaries (Wallace and Selman 1981; Heins and Baker 1988; Heins et al. 1992; Layman 1991, 1993). We determined fecundity for all individuals from all sites for the spring and summer seasons by teasing apart ovaries to provide a single ova layer for enumeration into each of the ova phase classes. This step was repeated until all ova were counted (Holmes et al. 2010; Stallsmith et al. 2015). Individual ova were assigned to a specific phase grouping; ova in each phase were counted. The diameters of 25 randomly selected oocytes from each size class present were recorded for each female. These oocytes size class diameters were measured 
using a Leica MZ12.5 stereomicroscope equipped with an ocular micrometer (Leica, Heerbrugg, Switzerland). No differences in egg size was encountered between the left and right ovaries of the same individual.

\section{Male reproductive condition}

Sexually mature male creek chubs are dichromatic during the spawning season.

Immature males are similar in general pigmentation patterns to females. Nuptial tubercles are large, sharp, keratinization in the epidermis of the head (Wiley and Collette 1970). Anywhere from 6-10 or as many as 12 tubercles occur seasonally on each side, extending posteriorly from the upper maxillae, in a single line parallel to the nostril, and arching over the eye (Trautman 1957, Ross 1975). As an indication of sexual maturation, Ross (1975) counted tubercles on the head of creek chubs, but Jensen et al. (2001) suggested subtle changes in tubercle expression may occur especially when examining effects of weak estrogenic compounds (Miles-Richardson et al. 1999). An index of tubercle intensity should be used to reflect both the numbers and relative development in males. Breeding tubercles were qualitatively classified by a single individual (to minimize sampling bias) on a scale of 0 to 4 with 0 being not present to 4 representing a complete compliment of large thickened tubercles.

Reproductive condition of males was further assessed 3 ways. First, a gonadal somatic index (GSI) was calculated for males $\geq 12$ months old by dividing gonadal mass by whole body mass. Second, when all 533 fish were dissected, all testes were visually described by color and condition. Third, testes reproductive condition was assessed histologically. Approximately 30 to 60 male fish per site were also randomly selected for 
histology so that testes could be qualitatively classified by spermatogenic status (Hudson River Natural Resource Trustees [HRNRT] 2001; Blazer 2002; Pinkney et al. 2017) and screened for the presence of ova in testes (Blazer 2002). We compared the reproductive status of testes against GSI and against tubercle maturity using both the gross visual classification and the histology classified status of testes to assess whether or not the visual classification was an effective (accurate) measure of male reproductive status. Testes were embedded in paraffin and $5 \mu \mathrm{m}$ serial sections were made using a ReichertJung Model 2030 microtome (Depew, NY). The slides were stained using the standard hematoxylin (H) and eosin (E) method (Presnell and Schreibman 1997). These stained sections were evaluated using a Leica DFC425C digital camera affixed to a Leica microscope (Leica Model DM2000, Heerbrugg, Switzerland) and gonad section images were taken using Leica Application Suite 3.8.0 imaging software.

\section{Plasma vitellogenin (Vtg) validation study}

In order to determine vitellogenin (Vtg) concentrations in creek chub plasma, a species specific standard had to be developed. We conducted a 14-day estrogenizing trial with creek chubs from our reference site (LI) in 2008 (Denslow et al. 2009) so that purified creek chub Vtg was available for the standard. Concentrations of Vtg were determined by a direct Enzyme-Link Immunosorbent Assay (ELISA) using monoclonal antibody (mAb) 2D3 developed for carp Vtg but validated for creek chub in 2008 (Denslow et al. 2009). To perform the assay, the plasma samples from the reference site were diluted appropriately and placed in wells of a 96-well plate and the assay was performed as described previously (Denslow et al. 1999). A standard curve diluted to the same extent 
as the samples was prepared and used with each experiment. The amount of Vtg in the plasma was determined by comparison to the standard curve (Denslow et al. 1999). The level of detection (LOD) for creek chub Vtg was $0.0005 \mathrm{mg} / \mathrm{mL}$. All assays were performed in triplicate and reported as the mean of the three measurements. The coefficient of variation was $<10 \%$ for all samples analyzed. Inter and intra-assay variability was routinely measured by analyzing controls on several plates and different runs was found to be $<10 \%$, and $<5 \%$, respectively (Denslow et al. 2009).

\section{Follow-up plasma hormones and Vtg survey}

In spring 2009, we collected creek chubs from 12 sites (Fig. 2). We examined plasma concentrations of E2, T and Vtg in male and female creek chubs at the 4 primary study sites plus an additional 8 sites having a range of PCB contamination (Table 1; and see Chapter 1 and Chapter 2 for more details). Creek chubs ( $n=\sim 12 /$ site) were captured from all 8 southern sites (these include the 4 primary sites) from March 24 through April 9 , 2009 and from 4 additional northern sites (Fig. 2) April 24 to April 27, 2009. Creek chubs were transported alive in coolers to the laboratory for individually processing within hours of capture. Funding constraints did not allow us to analyze male plasma samples for 11ketotestosterone (11-KT). Rather, we utilized $T$ to calculate $E_{2} / T$ (and $T / E_{2}$ ) ratios for males and females (Nichols et al. 1999; Giesy et al. 2003; Shang et al. 2006; Lui et al. 2009).

Blood plasma was collected as follows. Individual creek chubs were anesthetized using triaine methanesulfonate (MS222), and measured using total weight (g) and total length ( $T L$ in $\mathrm{mm}$ ). They were euthanized by severing the spinal cord at the base of the 
head. Blood was collected in heparinized capillary tubes (N. Denslow, personal communication). Capillary tubes were sealed, chilled and spun for 20 minutes. Plasma was removed (K. Kroll, personal communication) to prelabelled cryotubes and placed into liquid nitrogen. Plasma sex hormones were detected in male and female creek chubs using hormone enzyme-linked immunosorbent assay (ELISA) kits (Immuno-Biological Laboratories Inc., Minneapolis, MN) detection limits were $0.02 \mathrm{ng} / \mathrm{ml}$ for E2 and T.

\section{Statistics}

All statistical analyses were conducted using R (R Core Group 2013). All graphs were created using R or Excel (Microsoft Corp., Seattle, WA). Oocyte diameter, plasma hormones were compared across site and PCB contaminant classes via ANOVA. Regression analyses (fecundity versus age and size, PCBs, male and female GSI, Vtg, $E_{2}$ and tubercle score) were conducted using general linear model and regressions were compared using ANCOVA. Testes GSI were compared by ANOVA against histological spermatogenic status and visual classification to compare methods. Significant difference of means or significance in the model equation of $\alpha \leq 0.05$ were denoted.

\section{Results}

\section{Female reproductive condition and fecundity estimation}

We evaluated 511 female creek chubs that were 1+ years old in this study. The seasonal reproductive cycle appears to have been altered at the PCB-contaminated sites in subtle but important ways. Fig. 3 presents the overall ovary maturation status (Heins and Rabito 1986) of females captured during each month of the annual cycle, beginning with the lead 
up to the spawning season (Fig. 3a, LI - reference; Fig. 3b, ICS - high PCBs; Fig. 3c and Fig. 3d, CB and CC - medium PCBs) (see Tables 2 - 7 for details on sample sizes and calculated GSIs by maturation class). Several differences are evident, most notably the delay in ova maturation at the highest PCB site. In addition, several females from ICS had a complete complement of mature unspawned ova 2 or more months beyond the optimum spawning temperatures of early May which sets these individuals up for a monumental metabolic task of reallocating $8-15$ percent of body weight. We observed individuals from all of the PCB sites with ovaries containing large numbers of only atretic ova in July - December. The site-wide female GSIs (Fig. 4) further illuminate the inconsistent and delayed maturation for spawning (Fig. $4 \mathrm{~b}$ and $4 \mathrm{c}$ ), followed by a latent period and a significant, steady recrudescence beginning in the fall. GSIs at the PCB sites rarely achieve $7 \%$ in the winter months (Fig. $4 b-4 d$ ). A comparison of the seasonal presence and size (a function of quality) of phase I (Fig. 5a), phase II (Fig. 5b) and phase III (Fig. 5c) ova also indicates an altered timeline of maturation. There is an absence of phase I and II ova at the reference site in summer in contrast to ICS. Most telling is the presence of phase III (maturing) ova in late spring and summer at the PCB sites but not at the reference site. It is clear that phase I ova size increases with age of female (Table 6) and appropriate season of the year (Table 7). Mean Phase I and II ova sizes are significantly smaller at ICS than the reference site (Table 6). Estimates of total fecundity in creek chubs compare favorably to our reference site, LI (Table 8). Total fecundity for (including all ova sizes) for reference site (LI) females was strongly correlated with whole body mass ( $p$-value $<0.0001 ; R^{2}=0.64$ ), total length ( $p$-value $<0.0001 ; R^{2}=0.59$ ), and age in months ( $p$-value $<0.0001 ; R^{2}=0.56$ ), or years ( $p$-value $\left.<0.0001 ; R^{2}=0.50\right)$. Using 
ANCOVA, fecundity regressed against age in months does indicate that fecundity is reduced at ICS and CB (Table 9).

\section{Male reproductive condition}

The comparison of male reproductive condition assessment methods indicated that gross visual evaluation of the condition of the testes was an acceptable surrogate for histological evaluation. We visually evaluated 533 and histologically evaluated 111 male creek chubs that were 1+ years old. Very good separation occurred between the maturation stages in both the visual condition assessment and the histological assessment when comparing against GSI (Table 10). The visual category of "immature" was very similar in nature to pre-spermatogenic, the visual category of "in-between" consistently included early- and mid-spermatogenic, and the visually "mature" condition essentially equated to late spermatogenic stage. One difference between our observations and the histological mid-spermatogenic evaluation criteria as laid out for smallmouth bass (Blazer 2002; Pinkney et al. 2017) is that we did not observe even small numbers spermatozoa in what otherwise would appear to be creek chub midspermatogenic stage. This separation between testes maturation stage was also consistent between the visual and the histological evaluations when it came to assessment qualitative tubercle scores (Table 11). In addition, both testes classification schemes indicated that tubercles were much less pronounced at the PCB contaminated sites.

Consistent with females from these sites, male creek chubs at the PCB contaminated sites have delays and reductions in maturation (Fig. 6). Reference site 
creek chub male GSIs rarely peak above 2 percent in this study, but seasonal testes maturation pattern still appears to be altered compared to reference conditions. Figure 7 presents the overall visually determined testes maturation status of the population of males captured during each month of the an annual cycle, beginning with the lead up to the spawning season (Fig. 7a, LI - reference; Fig. 7b, ICS - high PCBs; Fig. 7c and Fig. 7d, CB and CC - medium PCBs) (see Tables 12 - 14 for details on sample sizes and calculated GSIs by visual maturation classification). It appears that the reference site (LI) has a small percentage of large older, sexually mature males that build nests and defend territories while many of the LI males do not exhibit full sexual maturity at an early age (Fig. 7a). These mature males are regressing toward latency by mid-May. Many CC males exhibited higher than expected GSI's in the summer (Fig. 7.d). Several of the August fish had enlarged and blackened testes of an undetermined nature. These lesions were also observed at CB in August and November (Fig. 7b), but not observed at either the most contaminated site, ICS or LI (reference site) (Fig. 7a). Another way to look at male GSIs is presented in Fig. 8. Sexually mature reference male GSIs peak February April, and regress in May (Fig. 8a). The peak is reduced in February and then extends through May at the high and medium PCB sites (Fig. 8b and 8c).

The most intriguing aspect of male sexual maturation at these sites had to do with the aberrations noted in regards to tubercles of the head (Fig. 9). At the reference site, the highest tubercle scores were from males with mature testes in February - April and strong pattern existed between seasonal recrudescence, maturation status and degree of tubercles (Fig. 9a). At the other sites, pattern of tubercles were almost never as strongly developed as the reference site (Table 16). Tubercles were found in all seasons of the 
year to varying degrees (Fig. 9b-9d) at the PCB contaminated site, and coincided with all stages of testes maturation. This included numerous instances of tubercles on males with immature testes (Fig. 9c and 9d). Ova-testes (OT) was not observed in any of the histologically evaluated testes from any of our study sites. Histological observations indicated a few male testes from lower Clear Creek (CC) with inflammation or numerous macrophage aggregations.

\section{Plasma hormones and Vtg survey}

One of the three batches of the testosterone plasma samples failed in the contract laboratory despite two analytical attempts and there was not enough plasma for a third attempt. No explanation was given for this failure. Male testosterone levels were not significantly different across sites but the BRUM reference site did have higher E2 levels than many of the other PCB sites (Table 17). Vtg was detected at very low levels in a few individual males from PCB streams but sites were not significantly different ( $p$-value $\sim 0.4$ ) (Table 17). Female vitellogenin concentrations were variable but not significantly different across all sites (Table 18). In general, plasma $E_{2}$ concentrations were lower and $T$ was higher in females from the PCB contaminated sites (Table 18). There was a significant difference between the $T / E_{2}$ ratio in females between the BRUM reference site and the high PCB site ICS (0.07 versus 4.1; ANOVA, p-value <0.013) (Table 18). This was also significantly different when sites were grouped across the PCB gradient $(p$-value $<0.018)$ (Fig. 10). Even with the very small female sample sizes, our data set confirms that female GSI is correlated with plasma Vtg concentrations and that female $E_{2}$ concentrations 
inversely correlate with mean site PCB creek chub tissue concentrations ( $p$-value < 0.011; $\left.R^{2}=0.28\right)$ (Table 19).

\section{Discussion}

\section{Timing of spawning season}

Water temperature is the most important external driver of creek chub spawning behavior (Miller 1967). Creek chub spawning occurred at water temperatures of 12 $18^{\circ} \mathrm{C}$ at our reference site ( $\left.\mathrm{LI}\right)$ and was completed by mid to late May. Creek chub spawning season occurs when stream water temperatures are $12-16^{\circ} \mathrm{C}$ (Greeley 1930; Ross 1977; McMahon 1982). Peak spawning period lasts 3 to 4 days (Ross 1976), which is also consistent with our observations. Creek chub are spawned in hatchery conditions at $15.6^{\circ} \mathrm{C}$ (Clark 1943). Creek chubs spawn in March in lowa and nest building started when temps reached $13-15^{\circ} \mathrm{C}$ (Paloumpis 1958). Moshenko and Gee (1973) found that spawning begins when daily minimum is at $11^{\circ} \mathrm{C}$ or above, and spawning is nearly over before daily maximum temperatures plateaus at $20^{\circ} \mathrm{C}$.

Spawning occurred during the last half of May in Manitoba (Moshenko and Gee 1973) and Ontario (Powles et al. 1977).

\section{Female reproduction implications}

Monthly mean female GSIs at LI peaked in March (well over 20 percent in some individuals), and by May, reference site mean female GSI was reduced ten-fold from maximums recorded in March. Moshenko and Gee (1973) reported that female GSIs peaked the third week in May. It is expected that Manitoba creek chub spawning (i.e. 
water temperatures) would be several weeks behind Indiana given the difference in latitude. Also, both of these data sets confirm that final gonadal maturation in creek chubs is very swift, often doubling to peak maturation within $3-14$ days. Ross (1976) determined that all females were spent as the brief spawning season came to an end. In streams not impacted by PCBs, we have never observed post-spawn female ovaries that contain many phase I (LM) or larger oocytes. Female GSIs from LI were less than 1 percent in June and by late summer, the presence of phase I oocytes began appearing in ever increasing size and numbers (Fig. 5a). This is consistent with the GSIs reported in the summer and fall in Ontario (Powles et al. 1977).

Reduced ovarian growth (as indicated by reduced GSI) was observed in creek chubs at these PCB-contaminated sites throughout the annual cycle (Fig. 3), and is consistent with Aroclor 1254 exposure in fish (Thomas 1988, 1989). Reduced ovarian growth is actually the result of reduced growth of the individual oocytes caused by reduced Vtg sequestration (Thomas 1999). There are several possible causes of Vtg production impairment associated with PCBs in these creek chubs: interferences with steroidogenesis (Thomas 1989; Khan and Thomas 1996), altered lipid metabolism (Stanton et al. 2003), or overall hepatic function declines (Chapter 2). Exposure to PCBs has been correlated with alterations in liver (e.g lipidosis, hepatomegaly; Nimmo et al. 1975; Hansen et al. 1976; Freeman et al. 1982; Cleland et al. 1988; Niimi 1996).

The most direct evidence in support of reduced ovarian growth and maturation is the interference with sex steroid levels. Female creek chubs from the PCBcontaminated streams in this study have lower plasma $\mathrm{E}_{2}$ and higher plasma $\mathrm{T}$ concentrations than reference streams (Table 18) during the spring spawning season. 
This would seem to indicate that PCB-caused neuroendocrine disruption is occurring. Several other authors have studied endocrine disruption chemicals (EDC) and have presented the ratio of $E_{2} / T$ (and $T / E_{2}$ ) as a biomarker to assess reproductive effects (summarized in Table 20). The type of sex steroid imbalance in female creek chubs from our PCB-contaminated sites does not fit the plasma sex steroid pattern of studies of sewage treatment plants, or androgen-containing runoff that animal feedlots generate (Table 20). The high levels of $\mathrm{T}$ is a symptom of (perhaps a logical biomarker for) a reduction in luteinizing hormone $(\mathrm{LH})$ release from the pituitary due to the failure of ovarian granulosa cells to convert $\mathrm{T}$ to $\mathrm{E}_{2}$ (Murphy et al. 2005; Dietrich and Krieger 2009).

The maturation process of oocytes to become viable ova is regulated by $\mathrm{LH}$ in two stages (Patino et al. 2001). Oocyte maturation competence (OMC) is a term that many authors have used to describe a late stage of development whereby the oocyte is released from meiotic arrest (Patino et al. 2001; Habibi and Andreu-Vieyra 2007). In the initial prolonged oocyte growth phase, Vtg is being sequestered in the oocytes as the follicle is developing the ability to produce maturation initiation hormone $(\mathrm{MIH})$. In the second stage, the follicle continues to respond to $\mathrm{LH}$ by producing MIH which releases the oocytes from meiotic arrest and ultimately leading to follicular release in preparation for spawning (Thomas 1999; Patino et al. 2001; Dietrich and Krieger 2009). Without appropriate amounts of $\mathrm{LH}$, the ability of the follicle cells to produce MIH does not happen, thus failure to reach OMC leads to failure to spawn.

It appears that many females from our PCB-contaminated sites fail to reach OMC because LH is lacking. This is indicated by delays in creek chub oocyte growth (Fig. 3), 
reduced oocyte size (Table 6), and reduced female plasma $E_{2}$ concentrations (Table 18). Oocyte maturation competence is under the control of the hypothalamus - pituitary - gonadal (HPG) axis involving several hormonal control systems (Thomas 1999; Patino et al. 2001; Dietrich and Krieger 2009). Aroclor 1254 impairs the release of gonadothropins $(\mathrm{Gn})$, primarily luteinizing hormone $(\mathrm{LH})$ from the pituitary into the bloodstream (Khan and Thomas 1997; Thomas 1999). In healthy fish, LH stimulates ovarian follicles to release $E_{2}$ to the blood which stimulates hepatic vitellogenesis $(\mathrm{Ng}$ and Idler 1983; Casillas et al. 1991). Vtg is released to the bloodstream and enters the ovarian follicle via capillaries in the thecal layer (Patino and Sullivan 2002). Oocytes have Vtg-receptors that bind with the Vtg to become yolk proteins (Mommsen and Walsh 1988). Chen et al. (1986) confirmed that Aroclor 1254 caused a reduction in Vtg production in rainbow trout (Oncorhynchus mykiss).

Even if successful spawning is occurring in the PCB-contaminated streams, the consequences of reduced egg size due to reductions in Vtg sequestration are still serious. Seelye and Mac (1981) determined that lake trout larval survivorship was correlated to egg and larval size, which in turn was inversely correlated with PCB concentrations. Polychlorinated biphenyls have also been linked to reduced egg hatch of spawned eggs (Hansen et al. 1973; Ankley et al. 1991) and reduced larvae survival (Hansen et al. 1975). Exposure to PCBs correlated with decreased weight and length in flounder larvae (Black et al.1988), and negatively correlated egg weights with PCB concentrations in rock sole livers (Johnson et al. 1998).

Delays in oocyte maturation would also result in increased atresia of ova that persist in the ovary as the water temperature window for the spawning season closes 
(Thomas 1999; Habibi and Andreu-Vieyra 2007). Exposure to PCBs has been implicated in increased oocyte atresia in many studies (Schimmel et al. 1974; Hogan and Brauhn 1975; Mauck et al. 1978; Zitko and Saunders 1979; Weis and Weis 1982; Niimi 1983; Monod 1985; Mac and Edsall 1991; Mac et al. 1993; Stouthart et al. 1998, Daouk et al. 2011). Increased atresia was also linked with an increase in adult female mortality (Black et al. 1998b) and reduced survivorship (Henshel et al. 2006; Chapter 4). Although we have observed some atresia and resorption of oocytes in creek chubs from uncontaminated streams, this is usually limited to tens, never more than hundreds of oocytes. We have also observed that when wide-scale oocyte atresia occurs (and we have only observed this in fish from PCB-contaminated streams), this extensive atresia occurs in creek chubs age 3 or less, and very few older females at the PCB-contaminated streams (Chapter 4).

Fecundity was reduced at our PCB-contaminated streams in comparison to our reference site (LI). Each season, nearly all oocytes except phase 0 (EM) oocytes develop to maturity, sometimes very quickly, and are totally spawned by the end of each spawning season (Fig. 3a and 4a). During September through December, oocytes begin advancing to phase II (LM) oocytes. Transition from phase II (LM) to phase III (MA) oocytes occurs rapidly in the winter portion of the year. Determining accurate mature (MA) ova counts in healthy fish is often difficult because the transition from MA to ripe (RE) ova can take place in a matter of hours, be quickly spawned, and missed by subsequent sampling efforts. In the spring, measures of fecundity give confusing results when comparing spawned females from the reference site versus delayed females from the PCBcontaminated sites. Late maturing (LM) or (MA) ova present in females at PCB- 
contaminated sites when water temperatures exceed $18^{\circ} \mathrm{C}$ (late May - June) will not be spawned. Although this may appear that PCB-contaminated females are more fecund in the summer months than the reference fish, the presence of severe oocyte atresia weeks to months post viable spawning temperatures is a negative outcome often seen in PCBcontaminated fish. Schemske (1974) found that fecundity was positively correlated with age and mass of creek chub females, and at the same time, PCBs have been associated with reduced female creek chub survival at our PCB-contaminated streams (Chapter 4). If the energetics of failed reproduction is a stress that decreases survivorship as other authors have shown (Black et al. 1998a), this is also an indirect negative impact on fecundity.

\section{Male reproduction implications}

Male sexual maturation was delayed / altered at these PCB-contaminated streams (Fig. 7). Although average male GSIs at our reference site (LI) never got as high as others have reported, ( 3 percent, Moshenko and Gee 1973), it is clear that older reference males testes matured fully in the proper season (Fig. 7a), unlike males from the PCB-contaminated streams (Fig. 7b - 7d). Polychlorinated biphenyls have been shown to alter the GnRH-LH system (Khan et al. 2001). The resulting reduction of LH to stimulate Ledig cells to steroidogenesis would result in reductions in spermatogonia proliferation (in Sertoli cells) and reductions in 11-ketotestosterone (11-KT) which would lead to reduced spermatogenesis (Schulz et al. 2001; Dietrich and Krieger 2009). We were not able measure 11-KT, which would have been the better approach to confirm PCBs were linked to our observed testes maturation impairments, however, our results are consistent with 
results from laboratory experiments (Freeman and Idler 1975; Sangalang et al. 1981; Freeman et al. 1982; Khan and Thomas 1996, Khan and Thomas 2001, Khan and Thomas 2006).

The evaluation of nuptial tubercles, a male secondary sex characteristic, has been a focus of much EDC investigations. The seasonal growth and regression of tubercles are primarily associated with the increasing and decreasing levels of androgens (primarily $T$ and 11-KT) (Ramaswami and Hasler 1955; Ankley et al. 2003) in late winter and early spring as the spawning season approaches (Greeley 1930; Ross 1975). Tubercles can be induced in female cyprinids by dosing with androgens such as testosterone propionate (Ramaswami and Hasler 1955) and 17a-trenbolone (Ankley et al. 2003; Jensen et al. 2006). In reference streams, post spawning male tubercles regress from stage 3 and 4 to stage 1 or 0 within a matter of weeks. In captivity, tubercles have been observed to slough off (Wiley and Collette 1970) post-spawning season. At our PCB-contaminated sites, tubercles were found on males at inappropriate times of the year, weakly expressed when compared to reference site males and inconsistent with stage of testes maturation within that same individuals at the PCB-contaminated streams (Fig. 9). There was a pattern of males having enlarged nuptial tubercles in the fall months as water temperatures decline from summer high temperatures $\left(\sim 23^{\circ} \mathrm{C}\right)$ through the optimum spawning temperature range $\left(18-12^{\circ} \mathrm{C}\right)$. It is likely that these aberrations result from the same PCB-induced neuroendocrine disruptions that appears to delay testes maturation (Fig. 7, Table 10). In addition, male creek chub maturation is delayed at these PCBcontaminated streams in comparison to female peak reproductive maturity (Fig. 6b - 6d). Social behaviors often trigger hormonal responses (Prasad et al. 2015; Parhar et al. 
2016). The spawning behavior of creek chubs are complex (Greeley 1930; Ross 1976;

Ross 1977) so delays of male sexual maturation during the spawning season may contribute to the delays and/or failed female spawning.

\section{Conclusions}

Given the many adverse effects observed in this study and the consistency with which our findings parallel the dozens of experimental laboratory studies cited herein, we have built a strong case for PCB-induced injury occurring in wild fish from PCBcontaminated streams in Indiana. Other field studies suggest PCBs do not have discernable population level effects on fish from PCB contaminated rivers such as the Hudson River (Barnthouse et al. 2003; Maceina and Sammons 2013) and Housatonic River (Reiser et al. 2004). Our data shows fecundity declines, poor sexual maturation in males, reduced female $E_{2}$, which likely leads to reduced Vtg and reduced oocyte growth, and likely LH reductions in females, all indicating that creek chubs are adversely impacted. Given the reliance on a surge of $E_{2}$ to produce Vtg for egg and larval viability (Murphy et al. 2005), and the reduction of spawning success (Daouk et al. 2011), it is more likely than not that reproductive impairment is occurring in creek chubs at these PCB-contaminated sites.

\section{References}

Armstrong BM, Lazorchak JM, Jensen KM, Haring HJ, Smith ME, Flick RW, Bencic DC, Biales AD (2016) Reproductive effects in fathead minnows (Pimphales promelas) following a $21 \mathrm{~d}$ exposure to 17a-ethinylestradiol. Chemosphere 144:366-373 
Ankley GT, Tillitt DE, Giesy JP, Jones PD, Verbrugge DA (1991) Bioassay-derived 2,3,7,8-tetrachlorodibenzo-p-dioxin equivalents in PCB-containing extracts from the flesh and eggs of Lake Michigan chinook salmon (Oncorhynchus tshawytscha) and possible implications for reproduction. Can J Fish Aquat Sci 48:1685-1690

Ankley GT, Jensen KM, Kahl MD, Korte JJ, Makynen EA (2001) Description and evaluation of a short term reproduction test with the fathead minnow (Pimephales promelas). Environ Toxicol Chem 20:1276-1290

Ankley GT, Jensen KM, Makynen EA Kahl MD, Korte JJ, Hornung, MW, Henry TR, Denny J., Leino RL, Wilson VS, Cardon MC, Hartig PC, Gray LE (2003) Effects of the androgenic growth promoter $17-\beta$-trenbolone on fecundity and reproductive endocrinology of the fathead minnow. Environ Toxicol Chem 22:1350-1360

Ankley, G.T., Miller DH, K.M. Jensen, M.D. Kahl, Villeneuve DL, Martinovic D (2008) Relationship of plasma sex steroid concentrations in female fathead minnows to reproductive success and population status. Aquat Tox 88:69-74

Baldigo BP, Sloan RJ, Smith SB, Denslow ND, Blazer VS, Gross TS (2006) Polychlorinated biphenyls, mercury, and potential endocrine disruption in fish from the Hudson River, New York, USA. Aquat Sci 68:206-228 
Barnthouse LW, Glaser D, Young J (2003) Effects of historic PCB exposures on the reproductive success of the Hudson River striped bass population. Environ Sci Technol $37: 223-228$

Bengtsson BE (1980) Long term effects of PCB (Clophen A50) on growth, reproduction and swimming performance in the minnow Phoxinus phoxinus. Water Res 14:681-687

Black DE, Gutjahr-Gobell R, Pruell RJ, Bergen B, Mills L, McElroy AE (1998a) Effects of a mixture of non-ortho- and mono-ortho-polychlorinated biphenyls on reproduction in Fundulus heteroclitus (Linnaeus). Environ Toxicol Chem 17:1396-1404

Black, DE, Gutjahr-Gobell R, Pruell RJ, Bergen B, Mills L, McElroy AE (1998b) Reproduction and polychlorinated biphenyls in Fundulus heteroclitus (Linnaeus) from New Bedford Harbor, Massachusetts, USA. Environ Toxicol Chem 17:1405-1414

Black, DE, Phelps DK, Lapan RL (1988) The effect of inherited contamination on egg and larval winter flounder Pseudopleuronectes americanus. Mar Environ Res 25:45-62

Blazer VS (2002) Histopathological assessment of gonadal tissue in wild fishes. Fish Physiol Biochem 26(1):85-101

Casillas E, Misitano D, Johnson LL, Rhodes LD, Collier TK, Stein JE, McCain BB, Varanasi U (1991) Inducibility of spawning and reproductive success of female English 
sole (Parophrys vetulus) from urban and nonurban areas of Puget Sound, Washington. Marine Environ Res 31:99-122

Chen TT, Reid PC, Van Beneden V, Sonstegard RA (1986) Effect of Arochlor 1254 and mirex on estradiol-induced vitellogenin production in juvenile rainbow trout (Salmo gairdneri). Can J Fish Aquat Sci 43:169-173

Clark CF (1943) Creek chub minnow propagation. Ohio Conservation Bull 7(6):12-13

Cleland GB, McElroy PJ, Sonstegard RA (1988) The effect of dietary exposure to Arochlor 1254 and/or mirex on humoral immune expression of rainbow trout (Salmo gairdneri). Aquat Toxicol (Amst.) 12:141-146

Collier TK, Stein JE, Sanborn HR, Hom T, Myers S, Varanasi U (1992) Field studies of reproductive success and bioindicators of maternal contaminant exposure in English sole (Parophtys vetulus). Sci Total Environ 116:169-185

Cross JN, Hose JE (1988) Evidence for impaired reproduction in white croaker (Genyonemus lineatus) from contaminated areas off southern California. Marine Environmental Research 24:185-188

Daouk T, Larcher T, Roupsard F, Lyphout L, Rigaud C, Ledevin M, Loizeau V, Cousin X (2011) Long-term food-exposure of zebrafish to PCB mixtures mimicking some 
environmental situations induces ovary pathology and impairs reproduction ability. Aquatic Toxicology 105:270-278

Denslow ND, Chow M, Kroll KJ, Green L (1999) Vitellogenin as a biomarker of exposure to estrogen or estrogen mimics. Ecotoxicology 8:385-398

Denslow ND (2009) Final Report Creek Chub Project, February 25, 2009. 4 pp

Dietrich DR, Krieger HO (2009) Histological analysis of endocrine disruptive effects in small laboratory fish. John Wiley \& Sons, Inc, Hoboken, New Jersey

Folmar LC, Denslow ND, Rao V, Chow M, Crain DA, Enblom J, Marcino J, Guillette LJ Jr (1996) Vitellogenin induction and reduced serum testosterone concentrations in feral male carp (Cyprinus carpio) captured near a major metropolitan sewage treatment plant. Environ Health Per 104:1096-1101

Freeman HC, Idler DR (1975) The effect of polychlorinated biphenyl on steroidogenesis and reproduction of brook trout (Salvelinus fontinalus). Can J Biochem 53:666-670

Freeman HC, Sangalang GB, Fleming B (1982) The sublethal effects of polychlorinated biphenyl (Arochlor 1254) diet on the Atlantic cod (Gadus morhua). Sci Total Environ 24:111 
Giesy JP, Snyder EM, Nichols KM, Snyder SA, Villalobos SA, Jones PD, Fitzgerald SD (2003) Examination of reproductive endpoints in goldfish (Carassius auratus) exposed in situ to municipal sewage treatment plant effluent discharges in Michigan, USA. Environ Toxicol Chem 22:2416-2431

Greeley JR (1930) A contribution to the biology of the horned dace, Semotilus atromaculatus Mitchill. PhD dissertation, Cornell University 208 pp

Habibi HR, Andreu-Vieyra CV (2007) Hormonal regulation of follicular atresia in teleost fish, pp 235-253. In Babin PJ, Cerda J, Lubzens E (eds) The fish oocyte: from basic studies to biotechnological applications. Springer NY

Halter MT, Johnson HE (1974) Acute toxicities of a polychlorinated biphenyl (PCB) and DDT alone and in combination to early life stages of coho salmon (Oncorhynchus kisutch). J Fish Res Board Can 31:1543-1547

Hansen DJ, Schimmel SC, Forester J (1973) Aroclor 1254 in eggs of sheepshead minnows: effects on fertilization success and survival of embryos and fry. Proc 27th Annu Conf Southeastern Assoc Game Fish Comm pp 420-426

Hansen DJ, Schimmel SC, Forester J (1975) Effects of Arochlor 1016 on embryos, fry, juveniles and adults of sheepshead minnows (Cyprinodon variegatus). Trans Am Fish Soc 3:584-588 
Hansen GL, Wiekhorst WB, Simon J (1976) Effects of dietary Aroclor 1242 on channel catfish (Ictalurus punctatus) and the selective accumulation of PCB components. J Fish Res Board Can 33:1343-1352

Heins DC, Baker JA, Dunlap WP (1992) Yolk loading in oocytes darters and its consequences for life-history study. Copeia 1992:404-412

Heins DC, Baker JA (1988) Egg sizes in fish: do mature oocytes accurately demonstrate size statistics of ripe ova? Copeia 1988(1):238-240

Heins DC, Rabito FG Jr (1986) Spawning performance in North American minnows: direct evidence of the occurrence of multiple clutches in the genus Notropis. J Fish Bio 28:343357

Henshel, DS, DW Sparks, TP Simon, and MJ Tosick (2006) Age structure and growth of Semotilus atromaculatus (Mitchill) in PCB-contaminated streams. J Fish Biology 68:4462

Hogan JW, Brauhn JL (1975) Abnormal rainbow trout fry from eggs containing high residues of a PCB (Arochlor 1242). Prog Fish-Cult 37:229-230

Holmes B, Whittington L, Marino L, Adrian A, Stallsmith B (2010) Reproductive timing of 
the Telescope shiner, Notropis telescopus, in Alabama, USA. Am Midl Nat 163:326-334

Hudson River Natural Resource Trustees (HRNRT)(2001) Sampling and Analysis Plan. Hudson River Fish Health Assessment. Phase I: Field Sampling, Necropsy, Histopathology, Disease, Fish Age (Field Version). Final Public Release Version. State of New York, U.S. Department of Commerce, U.S. Department of the Interior (Available from NOAA, Silver Spring, MD)

Indiana State Department of Health (ISDH) (1994) Preliminary data evaluation and pathway analysis report for consent decree PCB sites. Indianapolis, IN. 361 pp

Jensen KM, Korte JJ, Kahl MD, Pasha MS, Ankley GT (2001) Aspects of basic reproductive biology and endocrinology in the fathead minnow (Pimephales promelas). Comparative Biochemistry and Physiology Part C 128:127-141

Jensen KM, Makynen EA, Kahl MD, Ankley GT (2006) Effects of the feedlot contaminant 17a-Trenbolone on reproductive endocrinology of the fathead minnow. Environ Sci Technol 40:3112-3117

Johnson LL, Casillas E, Collier TK, McCain BB, Varanasi U (1988) Contaminant effects on ovarian development in English sole (Parophrys vetulus) from Puget Sound, Washington. Can J Fish Aquat Sci 45:2133-2146 
Johnson LL, Misitano D, Sol SY, Nelson GM, French B, Ylitalo GM, Hom T (1998) Contaminant effects on ovarian development and spawning success in rock sole from Puget Sound, Washington. Trans Am Fish Soc 127: 375-392

Khan, IA, Thomas P (1996) Disruption of neuroendocrine function in Atlantic croaker exposed to Aroclor 1254. Mar Environ Res 42:145-149

Khan IA, Thomas P (1997) Aroclor 1254-induced alteration in hypothalamic monoamine metabolism in the Atlantic croaker (Micropogonias undulatas): correlation with pituitary gonadotropin release. Neurotox 18:553-560

Khan IA, Thomas P (2001) Disruption of neuroendocrine control of LH secretion by Aroclor 1254 involves inhibition of hypothalamic tryptophan hydroxylase activity. Biol Reprod 64:955-964

Khan IA, Matthews S, Okuzawa K, Kagawa H, Thomas P (2001) Alterations in GnRH-LH system in relation to gonadal stage and Aroclor 1254 exposure in Atlantic croaker. Comp Biochem Physiol B 129:251-259

Khan IA, Thomas P (2006) PCB congener-specific disruption of reproductive neuroendocrine function in Atlantic croaker. Mar Environ Res 62:S25-S28

Layman SR (1991) Life history of the relict, duskytail darter, Etheostoma (Catonotus) 
sp., in Little River, Tennessee. Copeia 1991:471-485

Layman SR (1993) Life history of the savannah darter, Etheostoma fricksium, in the Savannah river drainage, South Carolina. Copeia 4:959-968

Lui C, Yu L, Deng J, Lam PKS, Wu RSS, Zhou B (2009) Waterborne exposures to fluorotelomer alcohol 6:2 $\mathrm{FTOH}$ alters plasma sex hormone and gene transcription in the hypothalamic-pituitary-gonadal (HPG) axis of zebrafish. Aquatic Toxicol 93:131-137

Mac MJ, Seelye JG (1981) Patterns of PCB accumulation by fry of lake trout. Bull Environ Contam Toxicol 27:368-375

Mac MJ, Edsall CC (1991) Environmental contaminants and the reproductive success of lake trout in the Great Lakes: an epidemiological approach. J Toxicol Environ Health 33:375-394

Mac MJ, Schwartz TR, Edsall CC, Frank A (1993) Polychlorinated biphenyls in Great Lake trout and their eggs: relations to survival and congener composition 1979-1988. J Great Lakes Res 19:752-765

Maceina MJ, Sammons SM (2013) Polychlorinated biphenyls in adult black bass and yellow perch were not associated with their reproductive success in the upper Hudson River, New York. Environ Toxicol Chem 32:1582-1591 
Mauck WL, Mehrle PM, Mayer FL (1978) Effects of the polychlorinated biphenyl Arochlor 1254 on growth, survival, and bone development in brook trout (Salvenlinus fontinalis). J Fish Res Board Can 35:1084-1088

McMahon, TE (1982) Habitat suitability index models: creek chub. US Fish and Wildlife Service FWS/OBS-82/104 pp 23

Miles-Richardson SR, Kramer VJ, Fitzgerald SD, Render JA, Yamini B, Barbee SJ, Giesy JP (1999) Effects of waterborne exposure of $17 \beta$-estradiol on secondary sex characteristics and gonads of fathead minnows (Pimephales promelas) Aquatic Toxicol $47: 129-145$

Miller RE (1967) Nest building and breeding activities of some Oklahoma fishes. Southwest Natur 12:463-468

Mommsen TP, Walsh PJ (1988) Vitellogenesis and oocyte assembly. In Hoar WS, Randall DJ (eds) Fish Physiology, Volume XI, The physiology of developing fish, Part A, Eggs and larvae. Academic Press, New York, pp 347-406

Monod G (1985) Egg mortality of Lake Geneva charr (Salvelinus alpinus L) contaminated by PCB and DDT derivatives. Bull Environ Contam Toxicol 35:531-536 
Monosson E, Fleming WJ, Sullivan CV (1994) Effects of the planar PCB 3,3'4,4'5tetrachlorobiphenyl (TCB) on ovarian development, plasma levels of sex steroid hormones and vitellogenin and progeny survival in white perch (Morone americana). Aquat Tox 29:1-19

Moshenko RW, Gee JH (1973) Diet, time and place of spawning, and environments occupied by creek chub (Semotilus atromaculatus) in the Mink River, Manitoba. J Fish Res Board Can 30:357-362

Murphy CA, Rose KA, Thomas P (2005) Modeling vitellogenesis in female fish exposed to environmental stressor: predicting the effects of endocrine disturbance due to exposure to a PCB mixture and cadmium. Reprod Toxicol 19:395-409

Nebeker AV, Puglisi FA, DeFoe DL (1974) Effects of polychlorinated biphenyl compounds on survival and reproduction of the fathead minnow and flagfish. Trans Am Fish Soc 103: 562-568

$\mathrm{Ng}$ TB, Idler DR (1983) Yolk formation and differentiation in teleosts fishes. In: Hoar WS, Randall DJ, Donaldson EM (eds) Fish Physiology Volume IX Reproduction Part A. Academic Press, New York, pp 373-403

Nichols KM, Miles-Richardson SR, Snyder EM, Giesy JP (1999) Effects of exposure to wastewater in situ on the reproductive physiology of the fathead minnow (Pimephales 
promelas). Environ Toxicol Chem 18:2001-2012

Niimi, AJ (1996) PCBs in aquatic organisms. In: Beyer WN, Heinz GH, Redmon-Norwood AR (eds) Environmental contaminants in wildlife: interpreting tissue concentrations. Lewis Publishers, Boca Raton, FL, pp 117-163

Niimi AJ (1983) Biological and toxicological effects of environmental contaminants in fish and their eggs. Can J Fish Aquat Sci 40: 306-312

Nimmo DR, Hansen DJ, Couch JA, Cooley NR, Parrish PR, Lowe JI (1975) Toxicity of Aroclor 1254 and its physiological activity in several estuarine organisms. Arch Environ Contam Toxicol 3:22-39

Orn S, Andersson PL, Forlin L, Tysklind M, Norrgren L (1998) The impact on reproduction of an orally administered mixture of selected PCBs in zebrafish (Danio rerio). Arch Environ Contam Toxicol 35:52-57

Paloumpis AA (1958) Responses of some minnows to flood and drought conditions in an intermittent stream. lowa State Coll J Sci 34(4):547-561

Parhar IS, Ogawa S, Ubuka T (2016) Reproductive neuroendocrine pathways of social behavior. Front. Endocrinol.7:28. doi:10.3389/fendo.2016.00028 
Patino R, Sullivan CV (2002) Ovarian follicle growth, maturation, and ovulation in teleost fish. Fish Physiol Biochem 26:57-70

Patino R, Yoshizaki G, Thomas P, Kagawa H (2001) Gonadotropic control of ovarian follicle maturation: the two-stage concept and its mechanisms. Comp Biochem Physiol B 129:427-439

Phillips EC, Ewert Y, Speares PA (2007) Fecundity, age and growth, and diet of Fundulus diaphanous (banded killifish) in Presque Isle Bay, Lake Erie. Northeastern Nat $14: 269-278$

Pinkney AE, Myers MS, Rutter MA (2017) Histopathology of brown bullhead (Ameiurus nebulosus), smallmouth bass (Micropterus dolomieu), and yellow perch (Perca flavescens) in relation to polychlorinated biphenyl (PCB) contamination in the Hudson River. Sci Total Environ 575:1325-1338

Powles PM, Parkes D, Reid R (1977) Growth, maturation, and apparent and absolute fecundity of creek chub, Semotilus atromaculatus (Mitchill) in the Kawartha Lakes region, Ontario. Can J Zool 55(5):843-846

Prasad P, Ogawa S, Parhar IS (2015) Role of serotonin in fish reproduction. Front. Neurosci. 9:195. doi:10.3389/fnins.2015.00195 
Presnell J, Schreibman M (1997) Humason's Animal Tissue Techniques, 5th edn. Johns Hopkins University Press, Baltimore, MD

R Core Team (2013) R: a language and environment for statistical computing. R Foundation for Statistical Computing, Vienna, Austria. [cited 2014 July 7] Available from: http://www.R-project.org/

Ramaswami LS, Hasler AD (1955). Hormones and secondary sex characteristics in the minnow, Hyborhynchus. Physiol Zool 28:62-68

Reiser DW, Greenberg ES, Helser TE, Branton M, Jenkins KD (2004) In situ reproduction, abundance, and growth of young-of-year exposed to polychlorinated biphenyls. Environ Toxicol Chem 23:1762-1773

Ross, MR (1975) The breeding behavior and hybridization potential of the northern creek chub Semotilus atromaculatus atromaculatus (Mitchell). The Ohio State Univ, ProQuest Dissertations Publishing, 7519485.

Ross, MR (1976) Nest-entry behavior of female creek chub (Semotilus atromaculatus) in different habitats. Copeia 1976:378-380

Ross, MR (1977) Function of creek chub (Semotilus atromaculatus) nest-building. Ohio J Sci 77(1):36-37 
Sangalang GB, Freeman HC, Crowell R (1981) Testicular abnormalities in Cod (Gadus morhua) fed Aroclor 1254. Arch Environ Contam Toxicol 10:627-635

Schemske DW (1974) Age, length and fecundity of the creek chub Semotilus atromaculatus (Mitchill) in central Illinois. Am Midl Nat 92:505-509

Schimmel SC, Hansen DJ, Forester J (1974) Effects of Aroclor 1254 on laboratory-reared embryos and fry of sheepshead minnows (Cyprinodon variegatus). Trans Am Fish Soc 103:582-586

Schulz RW, Vischer HF, Cavaco JEB, Santos EM, Tyler CR, Goos HJT, Bogerd J (2001) Gonadotropins, their receptors, and the regulation of testicular functions in fish. Comp Biochem Physiol B 129:407-417

Seeleys JG, Mac MJ (1981) Size specific mortality in fry of lake trout (Salvelinus namaycush) from Lake Michigan. Bull Environ Contam Toxicol 27:376-379

Sepulveda MS, Quinn BP, Denslow ND, Holm SE, Gross TS (2003) Effects of pulp and paper mill effluents on reproductive success of largemouth bass. Environ Toxicol Chem 22:205-213

Shang EH, Yu RMK, Wu RSS (2006) Hypoxia affects sex differentiation and 
development, leading to a male-dominated population in Zebrafish (Danio rerio). Environ Sci Technol 40:3118-3122

Sivarajah K, Franklin CS, Williams WP (1978a) The effects of polychlorinated biphenyls on plasma steroid levels and hepatic microsomal enzymes in fish. J Fish Biol 13:401-409

Sivarajah, K, Franklin CS, Williams WP (1978b) Some histopathological effects of Aroclor 1254 on the liver and gonads of rainbow trout, Salmo gairdneri, and carp, Cyprinus carpo. J Fish Biol 13:411-414

Spies RB, Rice DW (1988) Effects of organic contaminants on reproduction of the starry flounder Platichthys stellus in San Francisco Bay: II. Reproductive success of fish captured in San Francisco bay and spawned in the laboratory. Mar Biol 98: 191-200

Stallsmith B, Mann J, Allen C (2015) Reproductive timing of Erimystax insignis (blotched chub) in the Flint River of north Alabama. Southeastern Fishes Council Proc 55:62-73

Stanton BJ, DeWitt J, Henshel D, Watkins S Lasley BL (2003) Fatty acid metabolism in neonatal chickens (Gallus domesticus) treated with 2,3,7,8-tetrachlorodibenzo- $\rho$-dioxin (TCDD) or 3,3',4,4',5-pentachlorobiphenyl (PCB-126) in ovo. Comp Biochem Physiol C Toxicol Pharmacol 136:73-84

Stouthart XJHX, Huijbregts MAJ, Balm PHM, Lock RAC, Wendelaar Bonga SE (1998) 
Endocrine stress response and abnormal development in carp (Cyprinus carpo) larvae after exposure of the embryos to PCB 126. Fish Physiol Biochem 18:321-329

Thomas P (1988) Reproductive endocrine function in female Atlantic croaker exposed to pollutants. Marine Environmental Research 24: 179-183

Thomas P (1989) Effects of Arochlor 1254 and cadmium on reproductive endocrine function and ovarian growth in Atlantic croaker. Mar Environ Res 28: 499-503

Thomas, $\mathrm{P}$ (1999) Disruption of the endocrine control of final oocyte maturation in teleosts by xenobiotic chemicals. In Henshel DS, Black MC, Harras MC (eds) Environmental Toxicology and Risk Assessment: standardization of biomarkers for endocrine disruption and environmental assessment, 8th volume, ASTM STP 1364, American Society for Testing and Materials, West Conshohocken, PA, pp 165-181

Trautman MB (1957) The fishes of Ohio. Ohio State University Press

Wallace RA, Selman K (1981) Cellular and dynamic aspects of oocyte growth in teleosts. Am Zool 21:326-343

Washburn GN (1948) Propagation of the creek chub in ponds with artificial raceways. Trans Amer Fish Soc 75:336-350 
Weis P, Weis JS (1982) Toxicity of PCBs Aroclor 1254 and 1242 to embryos and larvae of the mummichog, Fundulus heteroclitus. Bull Environ Contam Toxicol 28:298-304

Wiley ML, Collette BB (1970) Breeding tubercles and contact organs in fishes: their occurrence, structure and significance. Bull Am Mus Nat History 143:143-216

Zitko V, Saunders RL (1979) Effects of PCBs and other organochlorine compounds on the hatchability of Atlantic salmon (Salmo salar) eggs. Bull Environ Contam Toxicol $21: 125-130$ 
Fig. 1. Location of the primary study sites in the White River drainage, including: upper and lower Clear Creek (ICS and CC), Conards Branch / Richland Creek (CB) and reference site Little Indian Creek (LI), Indiana. 


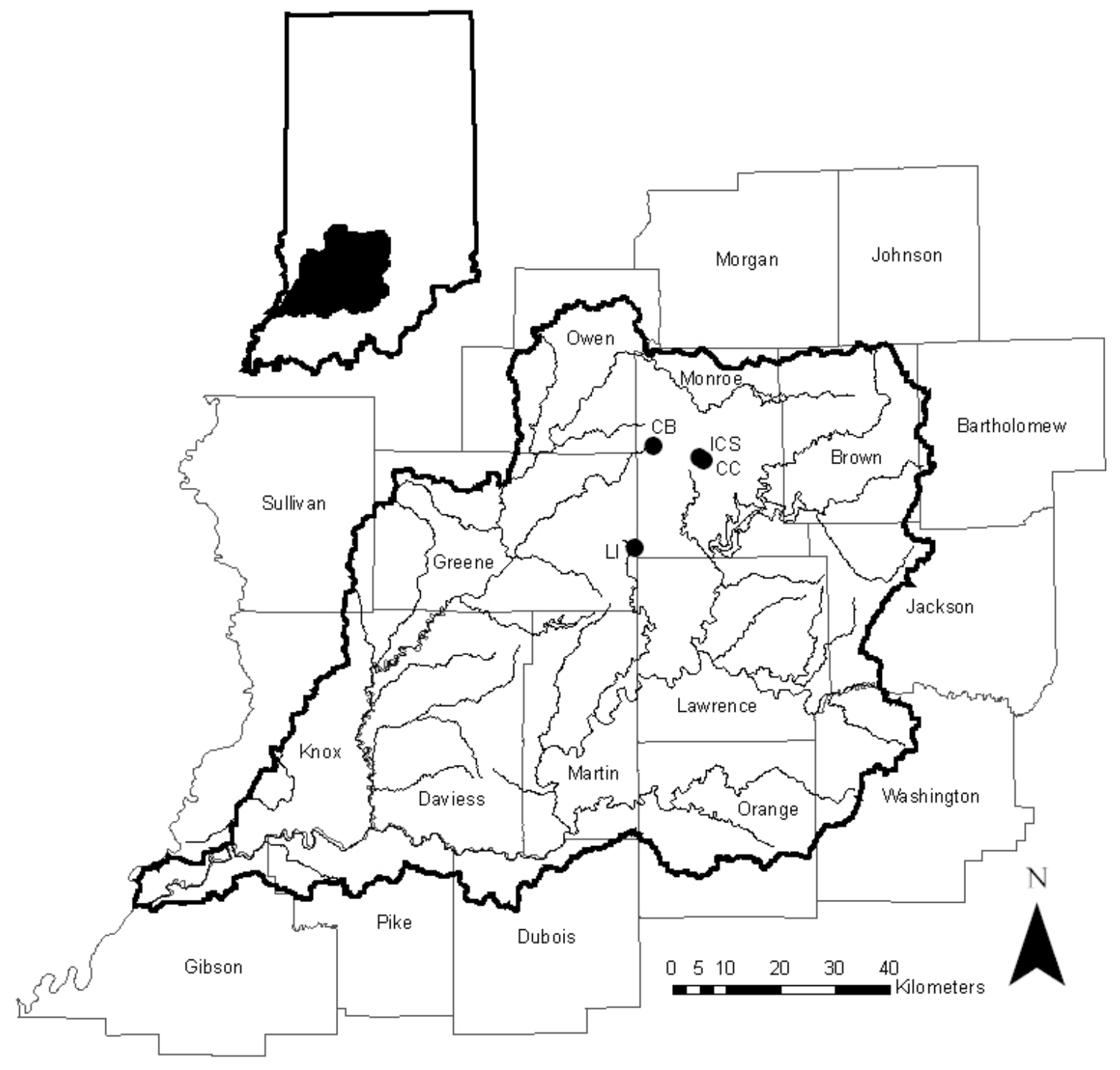


Fig. 2. The 2009 creek chub sampling sites from nine locations on seven PCBcontaminated streams: upper and lower Clear Creek (ICS and CC), Conards Branch / Richland Creek (CB), Stouts Creek (SC), Sinking Creek (ABB) in Monroe County, Pleasant Run Creek (PR) in Lawrence County, the Little Mississenewa River (LM1 and LM2) in Randolph County, and Elliot Ditch / Wea Creek (ED2) in Tippecanoe County, Indiana. Also included are two uncontaminated reference sites: Little Indian Creek (LI), and Brummett Creek (BRUM), Greene and Monroe Counties and a slightly elevated background stream, Burnetts Creek (BC) in Tippecanoe County, Indiana. 


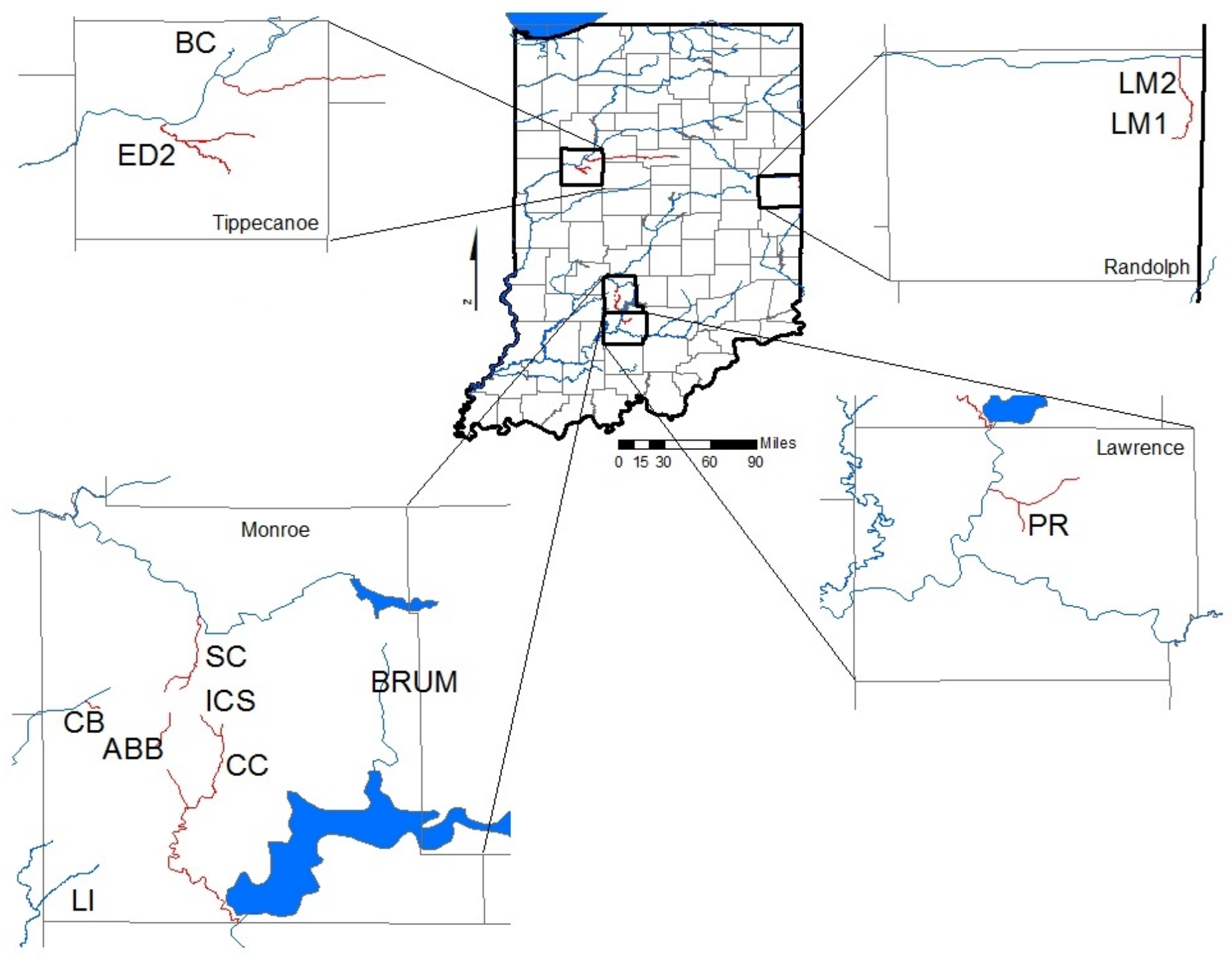


Fig. 3. Overall female creek chub ovarian condition based on the classification scheme from Heins and Rabito (1986) at: a) the reference site Little Indian Creek (LI), b) upper Clear Creek (ICS), c) Conards Branch / Richland Creek (CB) and d) lower Clear Creek (CC). Mature (MA) ovaries contain mostly phase III ova; Late Maturing (LM) ovaries contain mostly phase II ova; Latent (LA) / Early Maturing (EM) ovaries contain only phase 0 or phase I ova; atretic denotes that the majority of oocytes present are deteriorating. 
a
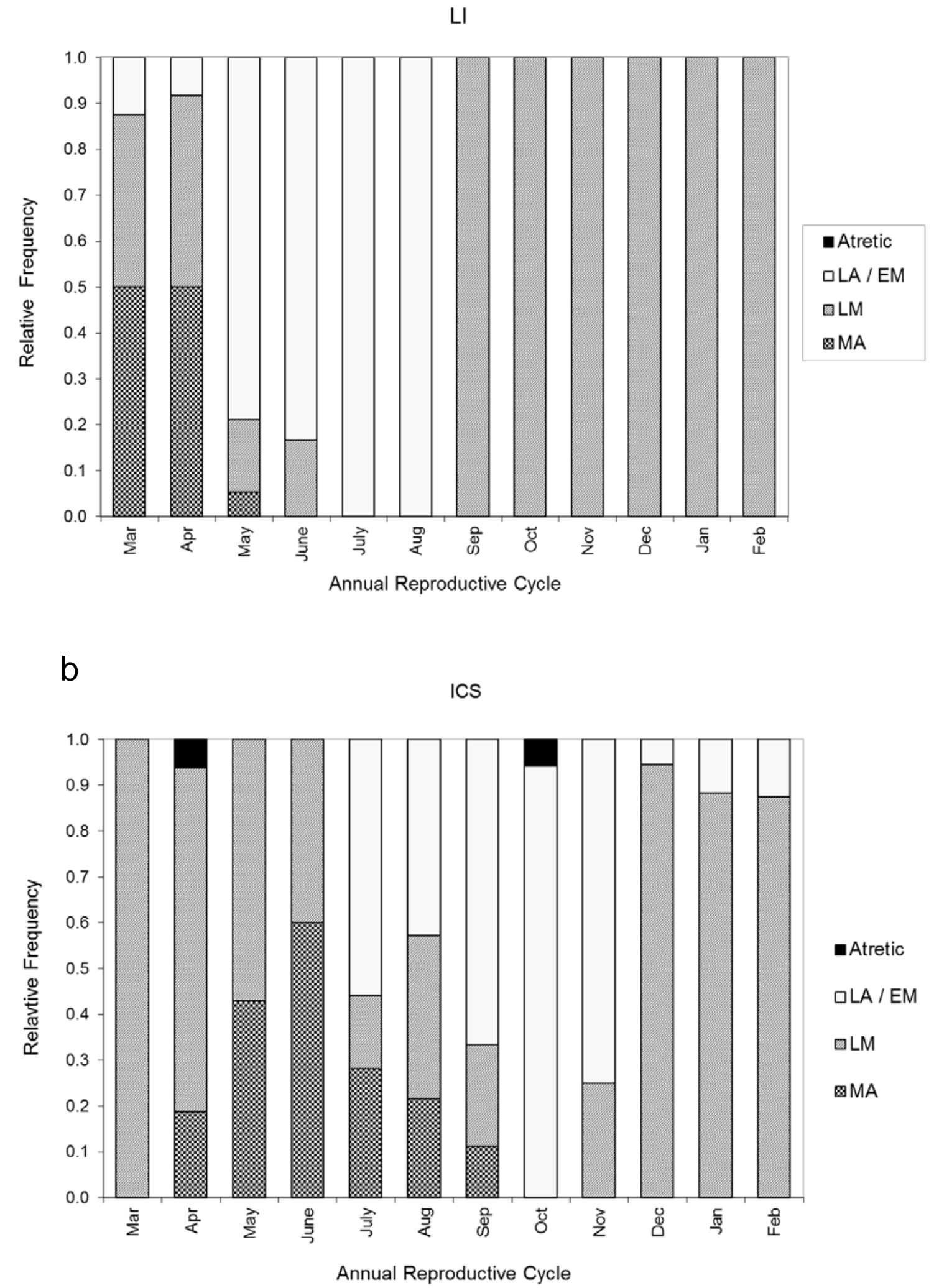


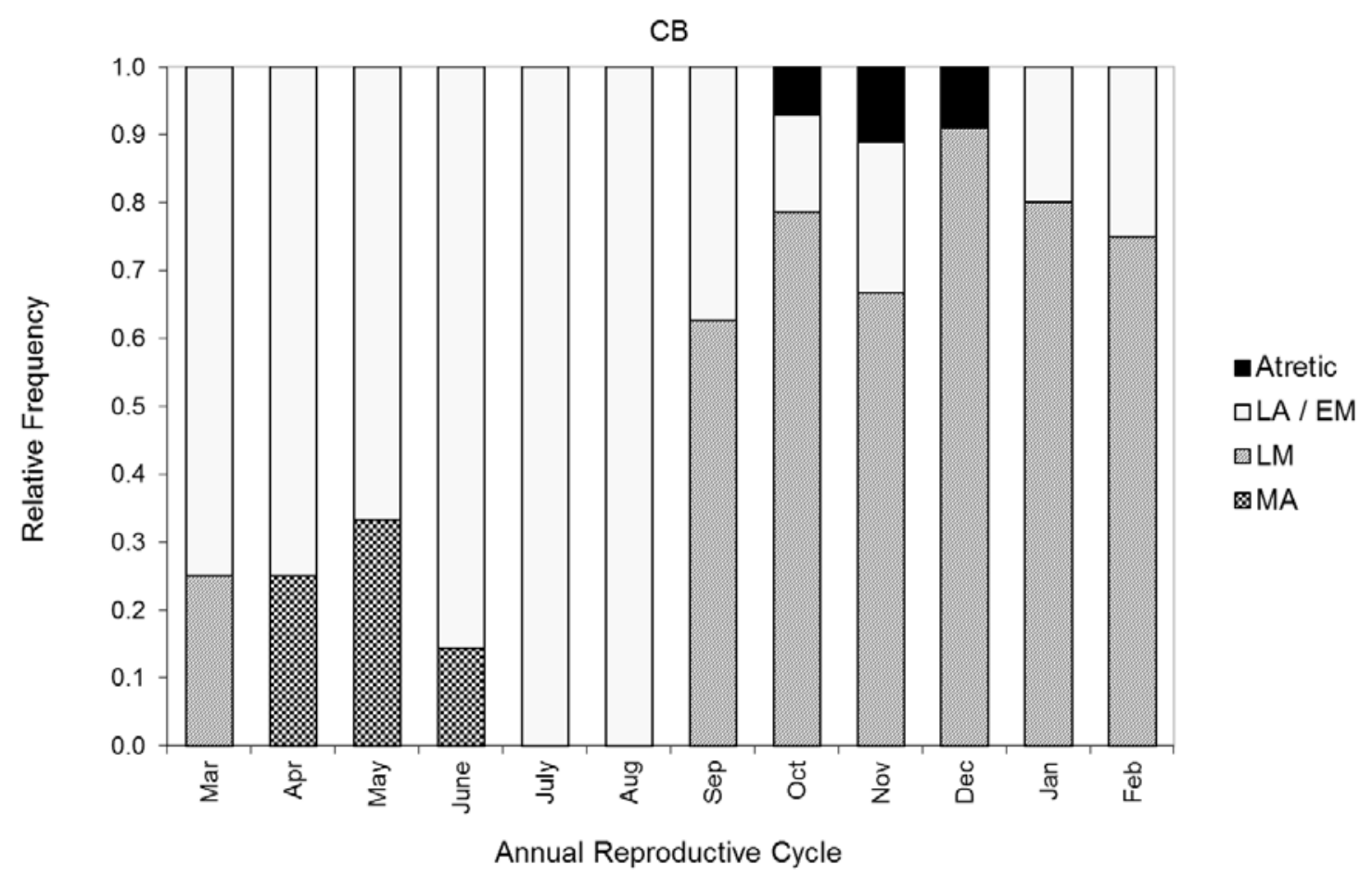

d

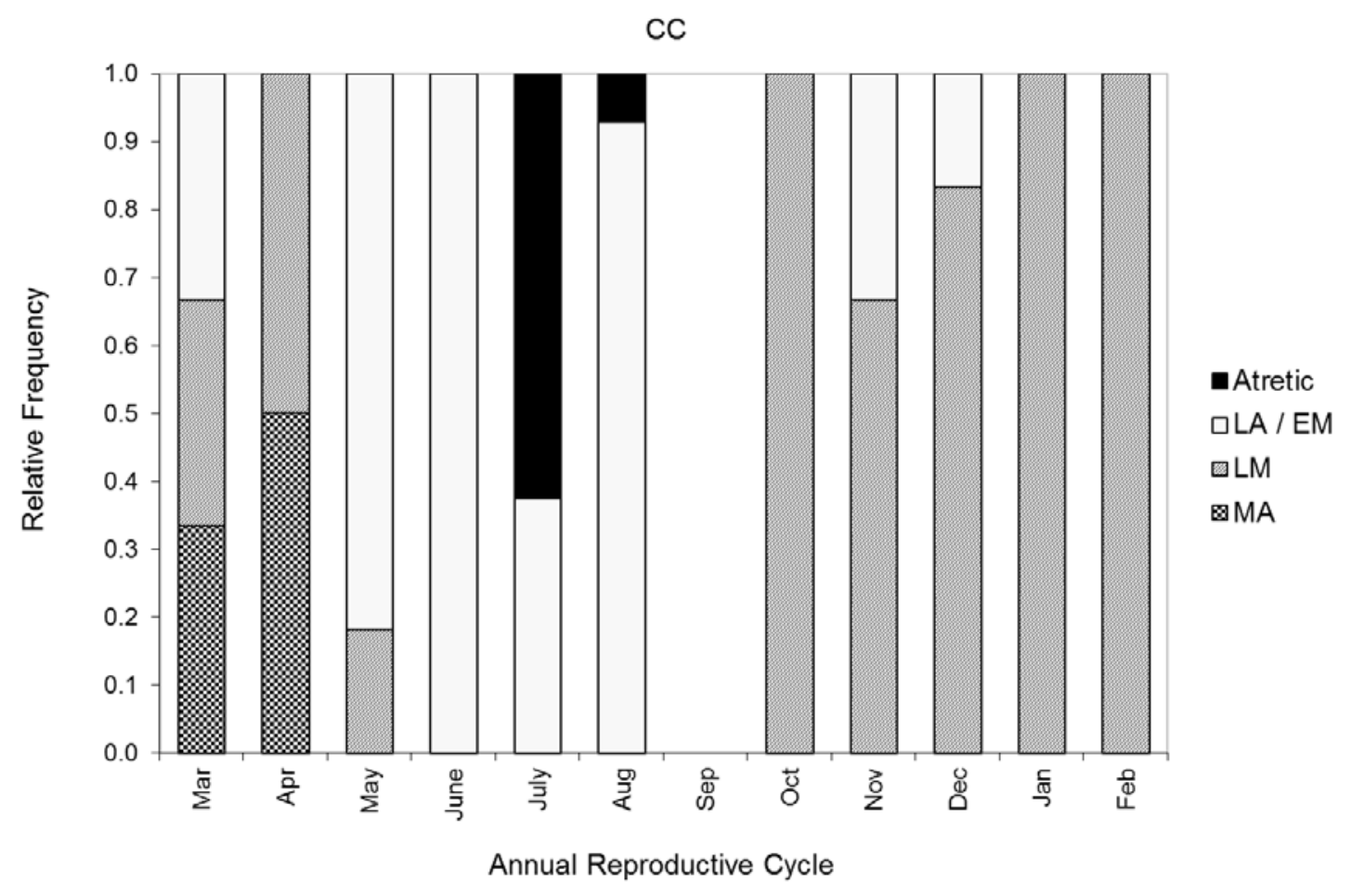


Fig. 4. Female creek chub gonadal (ovarian) somatic index (GSI) based on the classification scheme from Heins and Rabito (1986) at: a) the reference site, Little Indian Creek (LI), b) upper Clear Creek (ICS), c) Conards Branch / Richland Creek (CB) and d) lower Clear Creek (CC). Monthly mean GSIs also presented by category of maturation: Mature (MA) ovaries contain mostly phase III ova; Late Maturing (LM) ovaries contain mostly phase II ova; Latent (LA) / Early Maturing (EM) ovaries contain only phase 0 or phase I ova; atretic denotes that the majority of oocytes present are deteriorating; mean equates to overall mean for all females analyzed each month. 
a

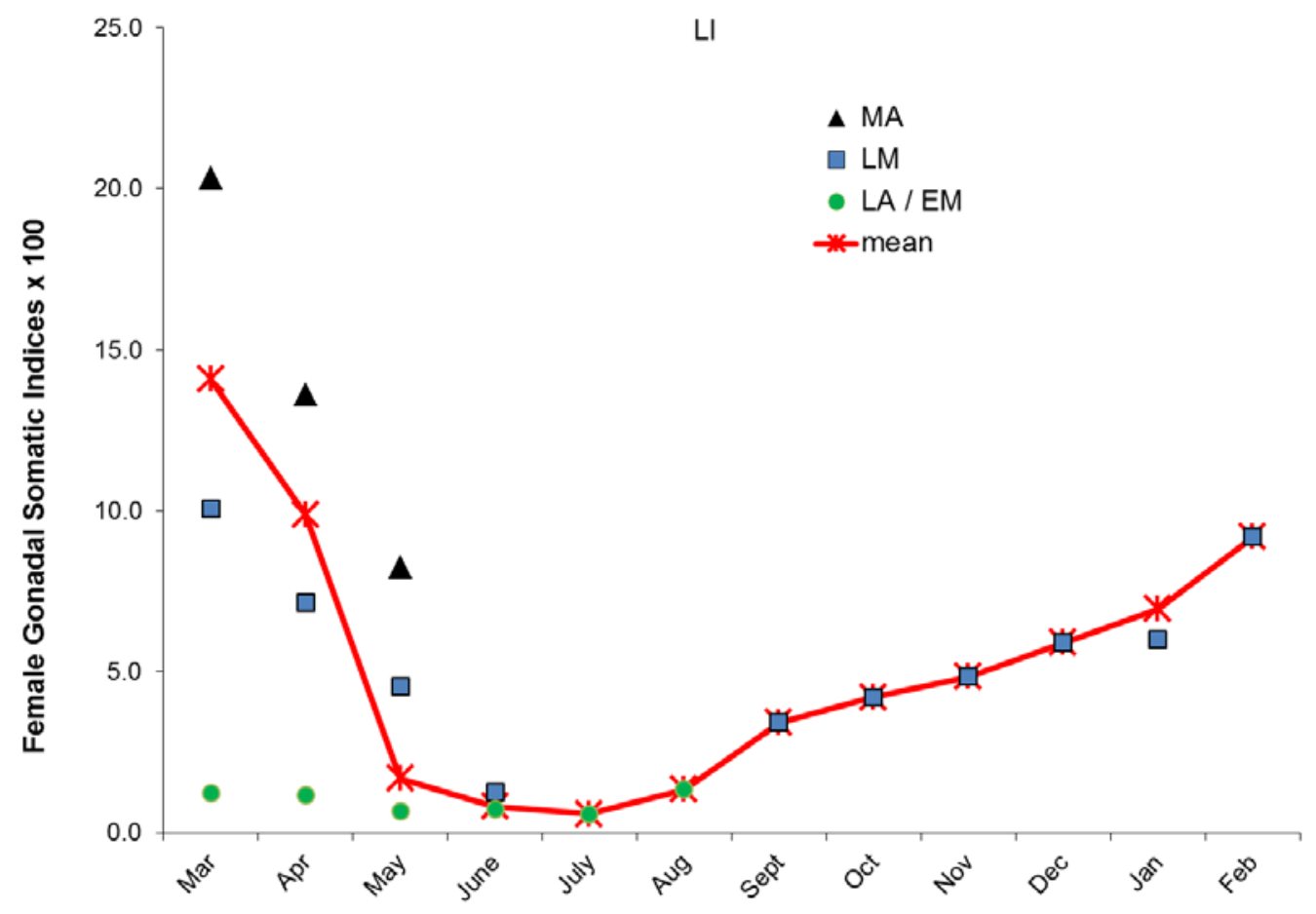

Annual Reproductive Cycle

b

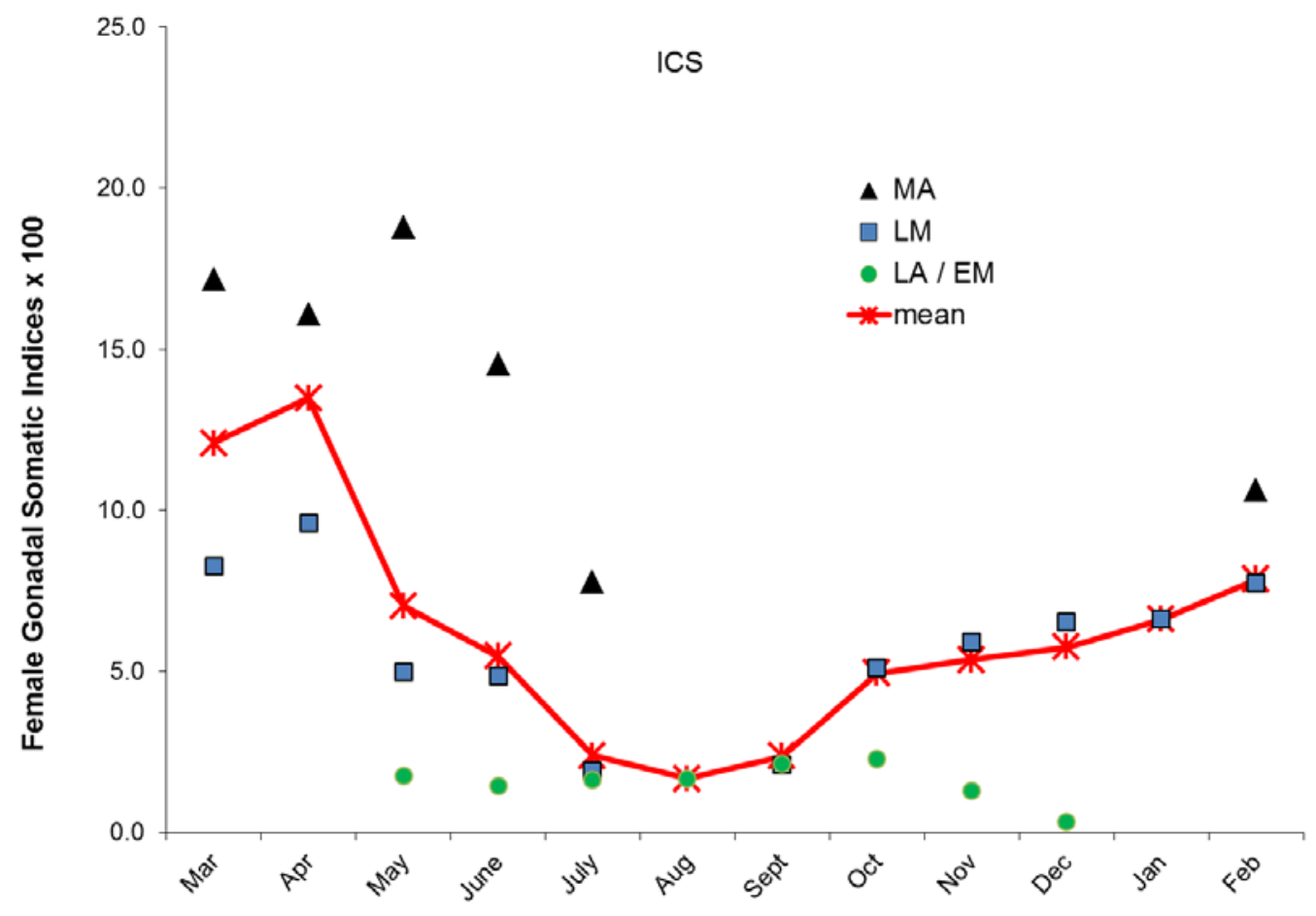

Annual Reproductive Cycle 
C
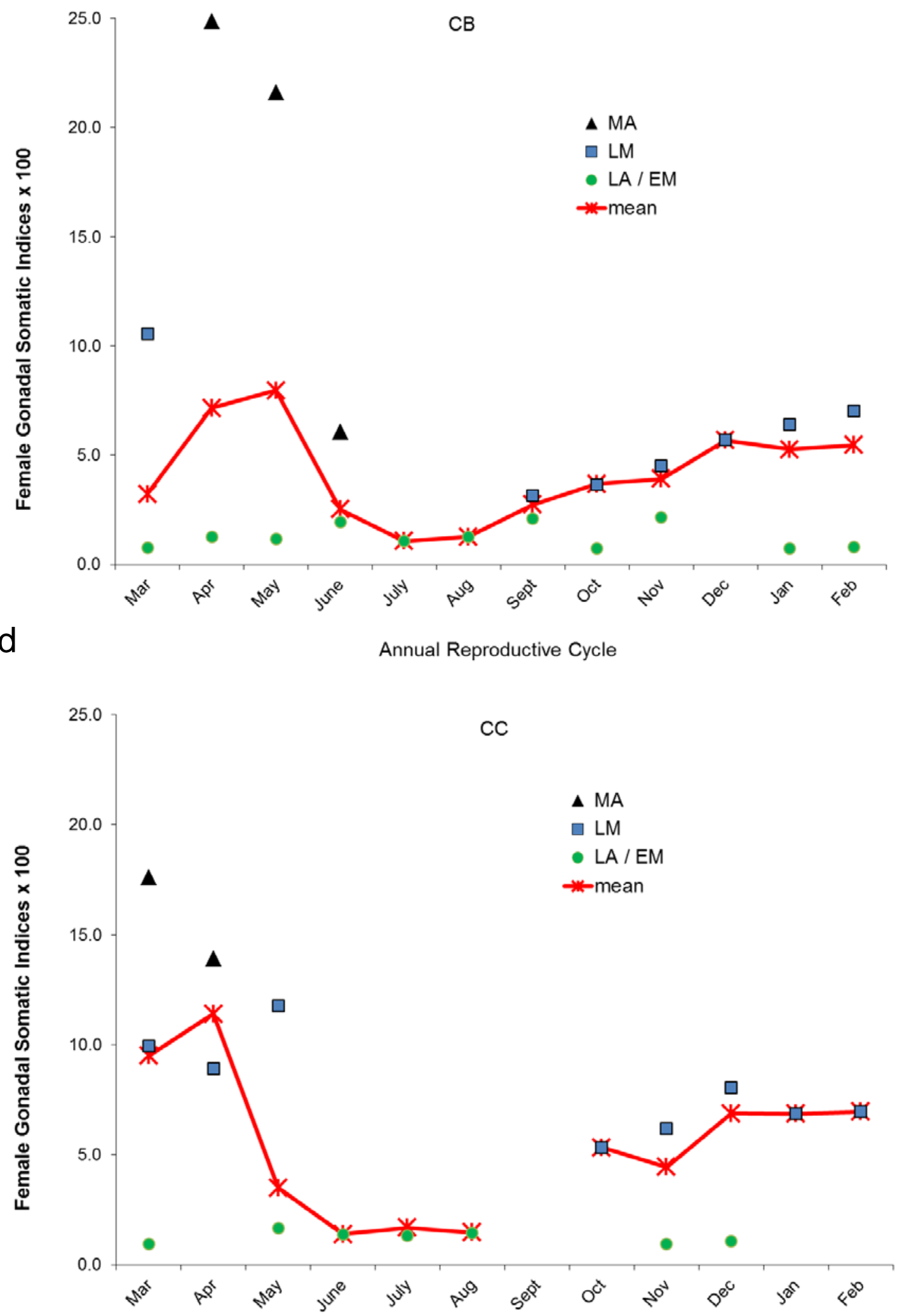

Annual Reproductive Cycle 
Fig. 5. Female creek chub mean ova sizes $(\mathrm{mm})$ for each month of the year from the reference site, Little Indian Creek (LI), upper Clear Creek (ICS), Conards Branch / Richland Creek (CB) and lower Clear Creek (CC): a) Phase I ova, b) Phase II ova, and c) Phase III ova. For comparison purposes, the line and error bars reflect reference conditions at LI. 
a

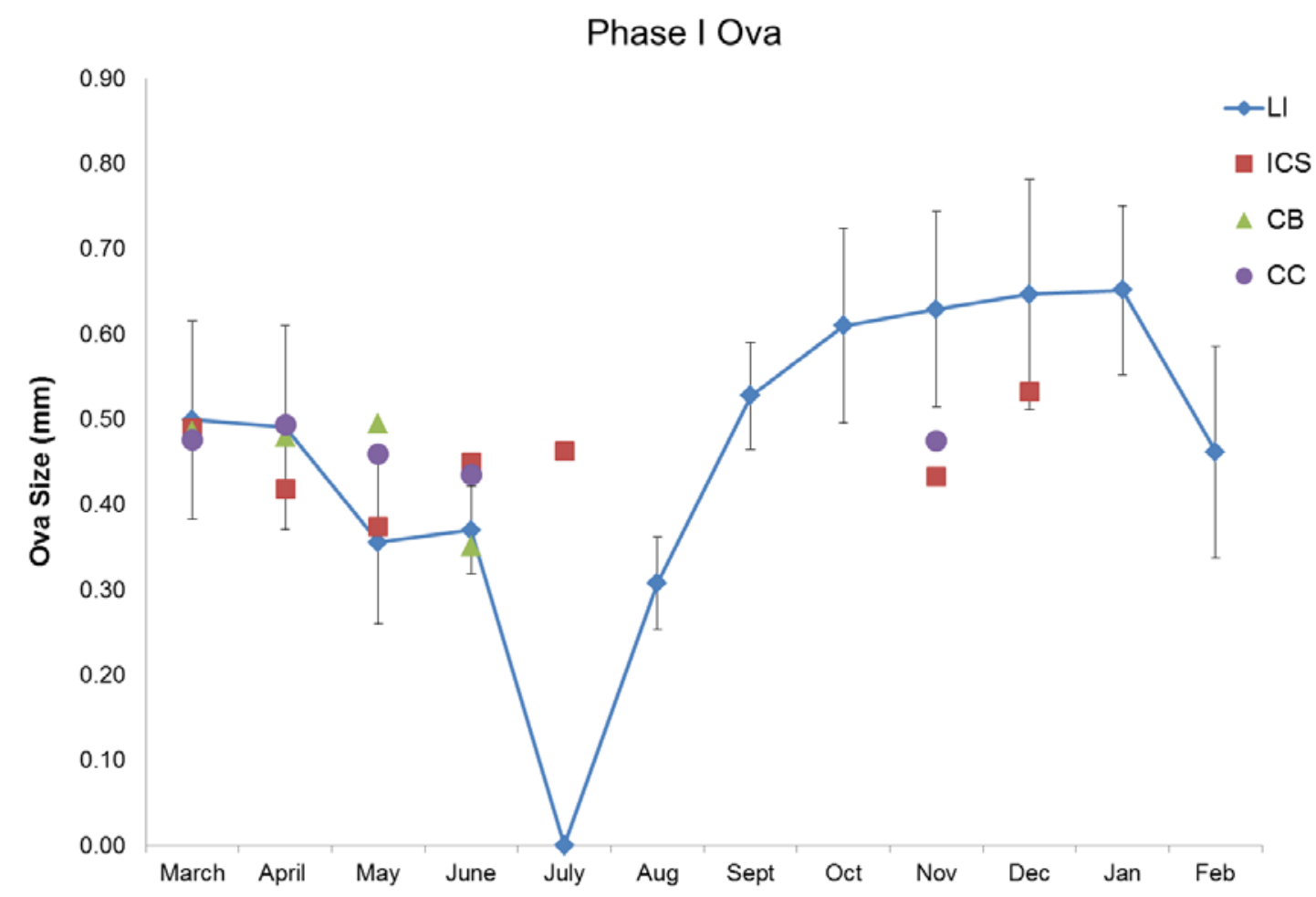

Annual Reproductive Cycle

b

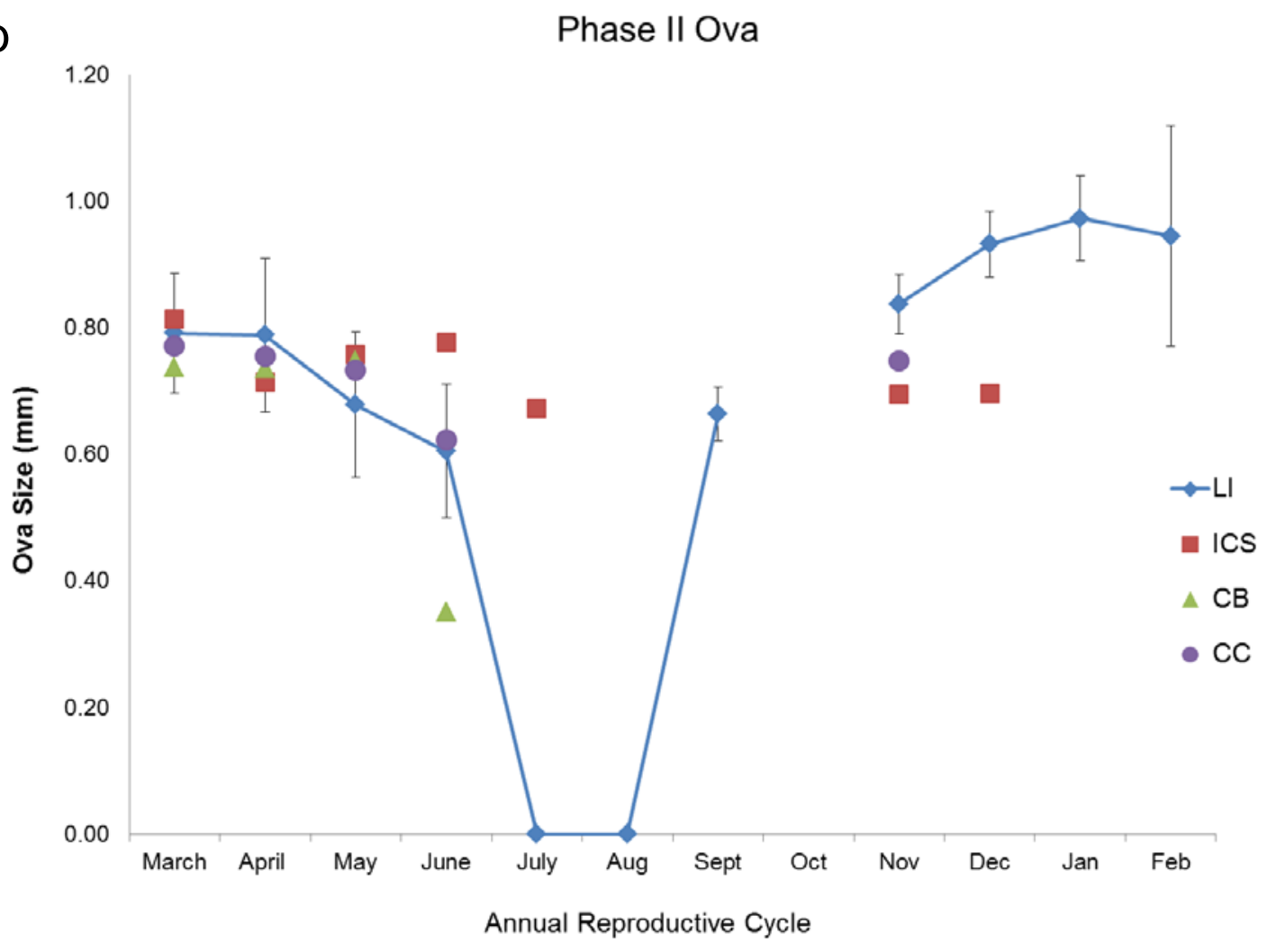


C

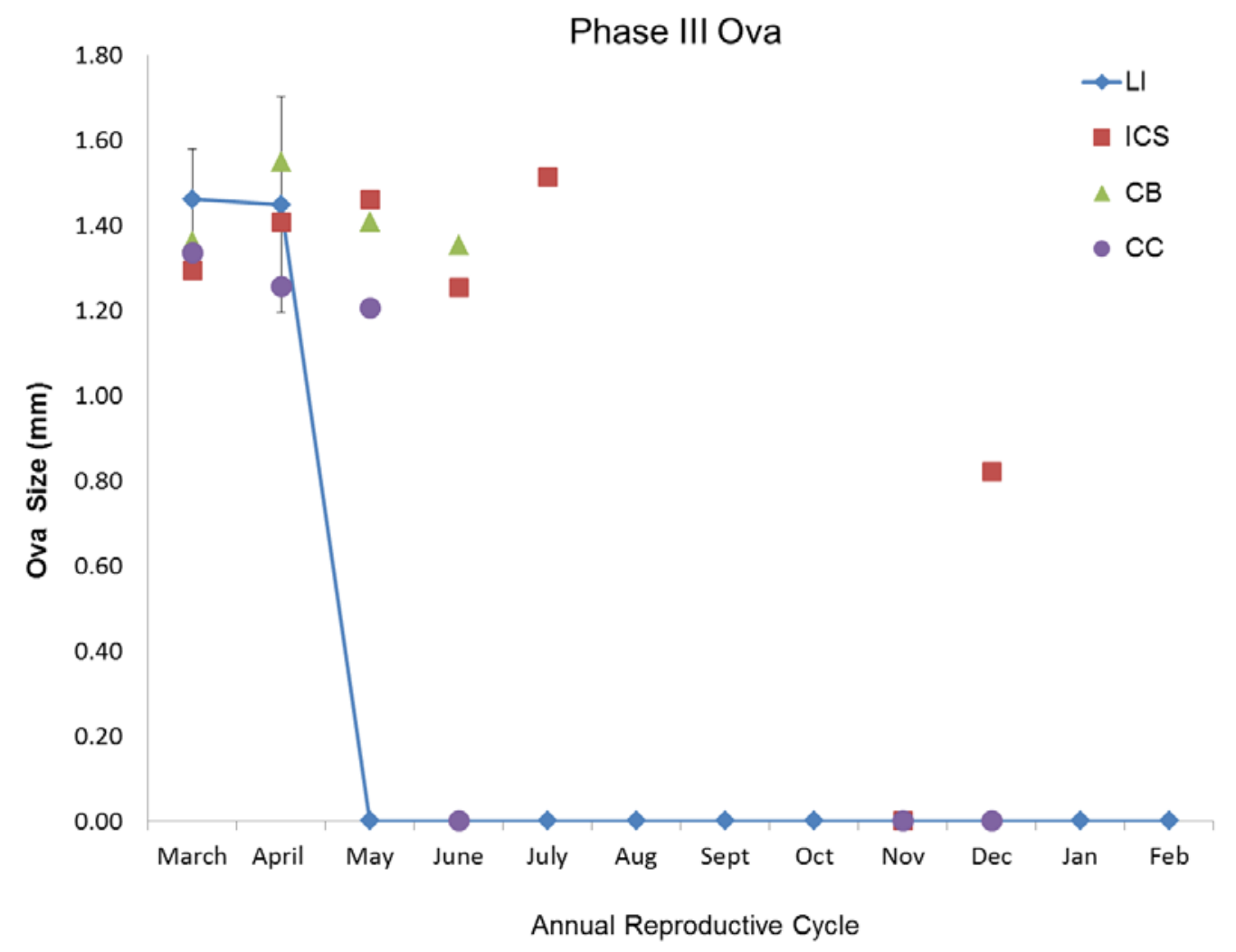


Fig. 6. Male and female creek chub gonadal somatic index (GSI) at: a) the reference site, Little Indian Creek (LI), b) upper Clear Creek (ICS), c) Conards Branch / Richland Creek (CB) and d) lower Clear Creek (CC). 
a

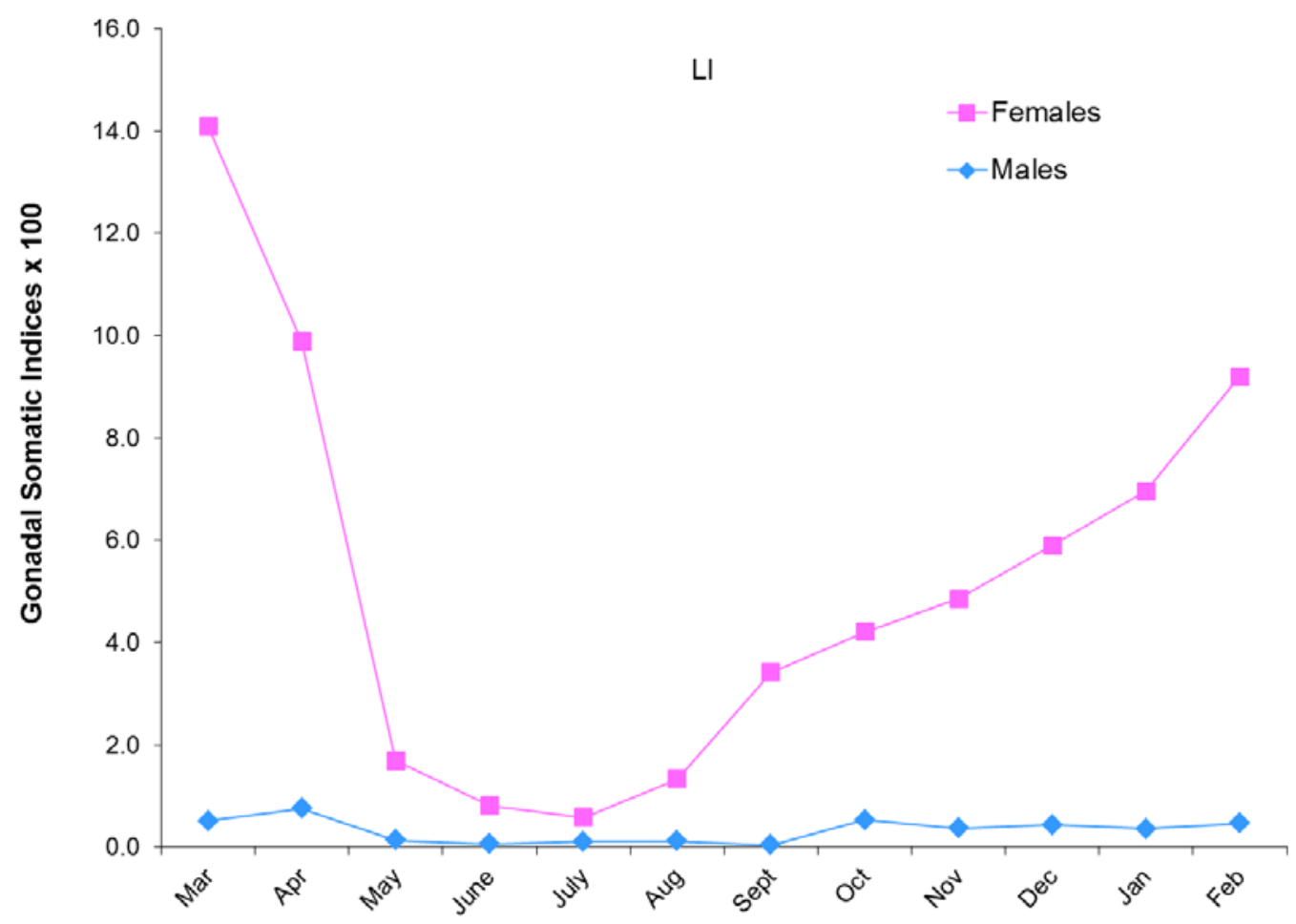

Annual Reproductive Cycle

b

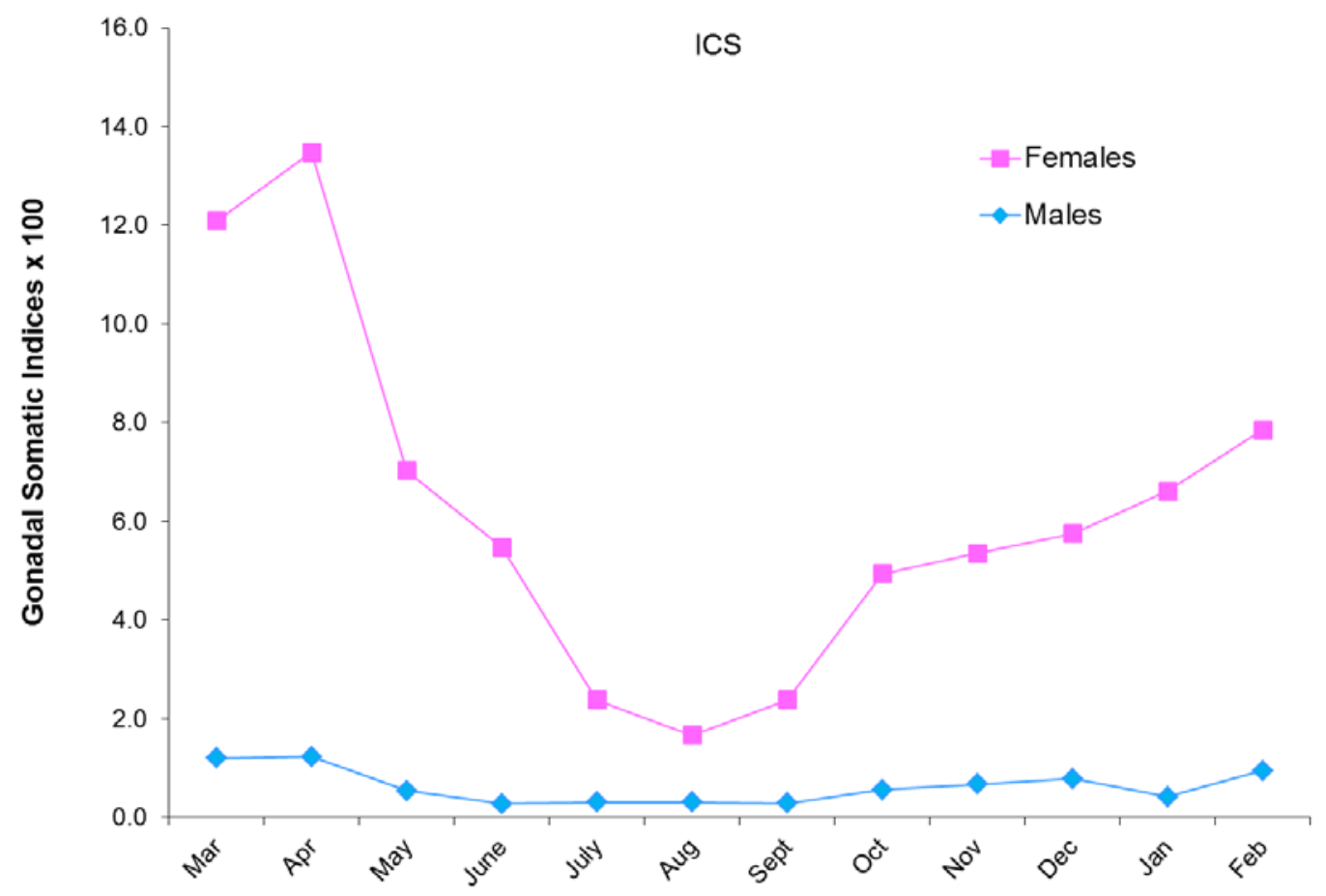

Annual Reproductive Cycle 


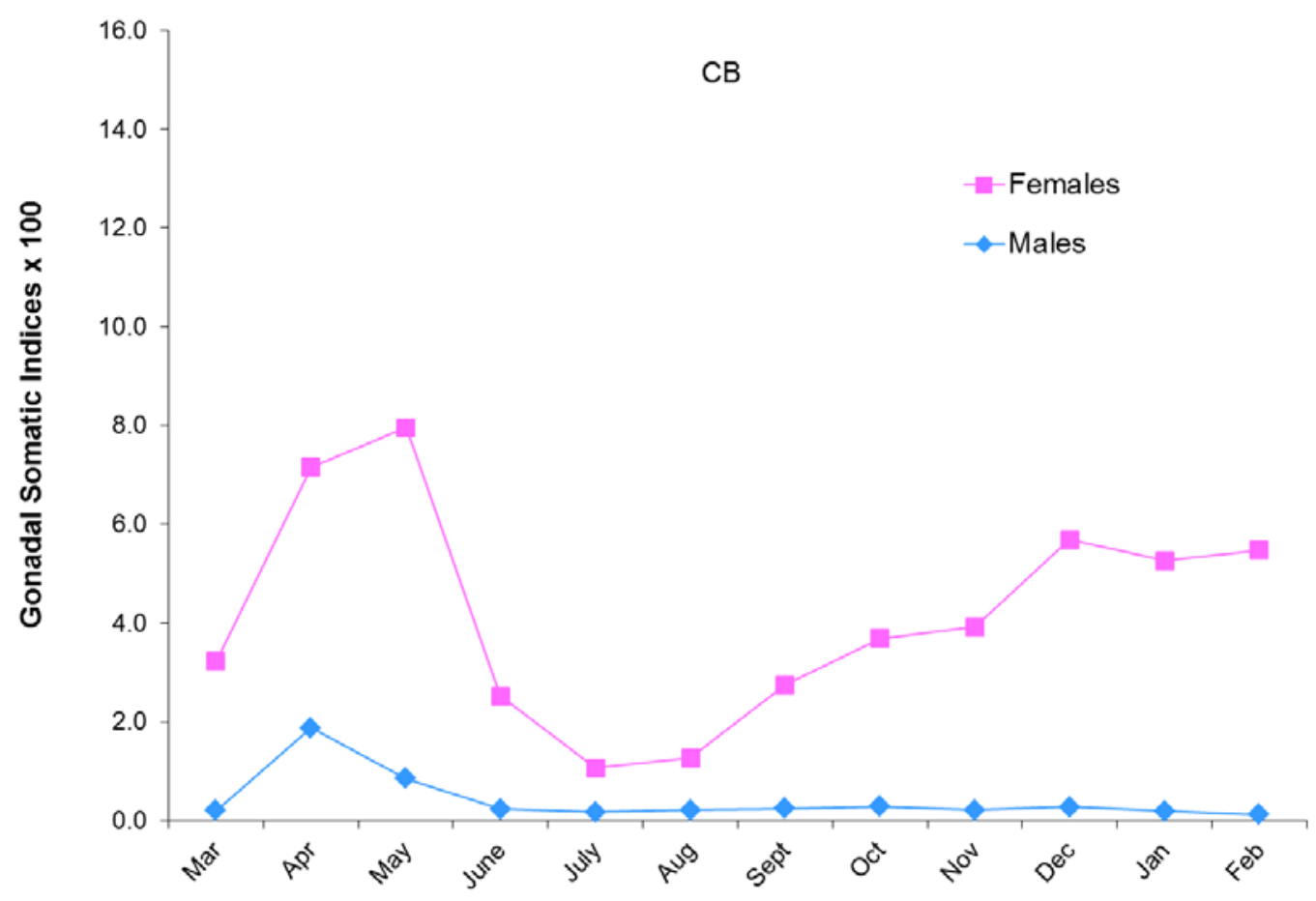

Annual Reproductive Cycle

d

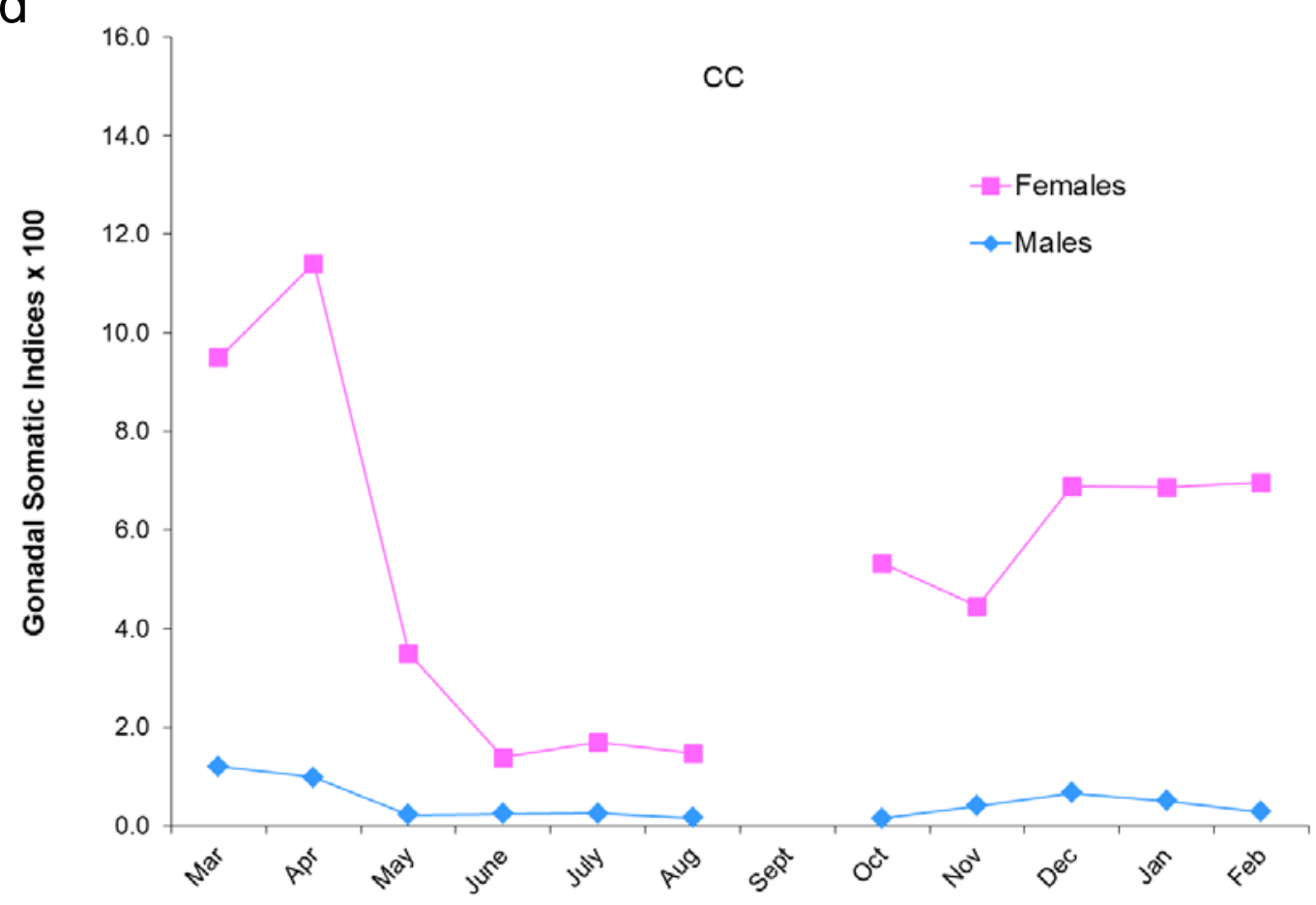

Annual Reproductive Cycle 
Fig. 7. Overall creek chub testes condition (maturation stage) at: a) the reference site, Little Indian Creek (LI), b) upper Clear Creek (ICS), c) Conards Branch / Richland Creek (CB) and d) lower Clear Creek (CC). The visual categories of "immature" was very similar in nature to pre-spermatogenic; "in-between" consistently included early- and midspermatogenic; and "mature" condition essentially equates to late spermatogenic stage. "Blackened" denotes deteriorating testes of an undetermined nature. 
a

LI

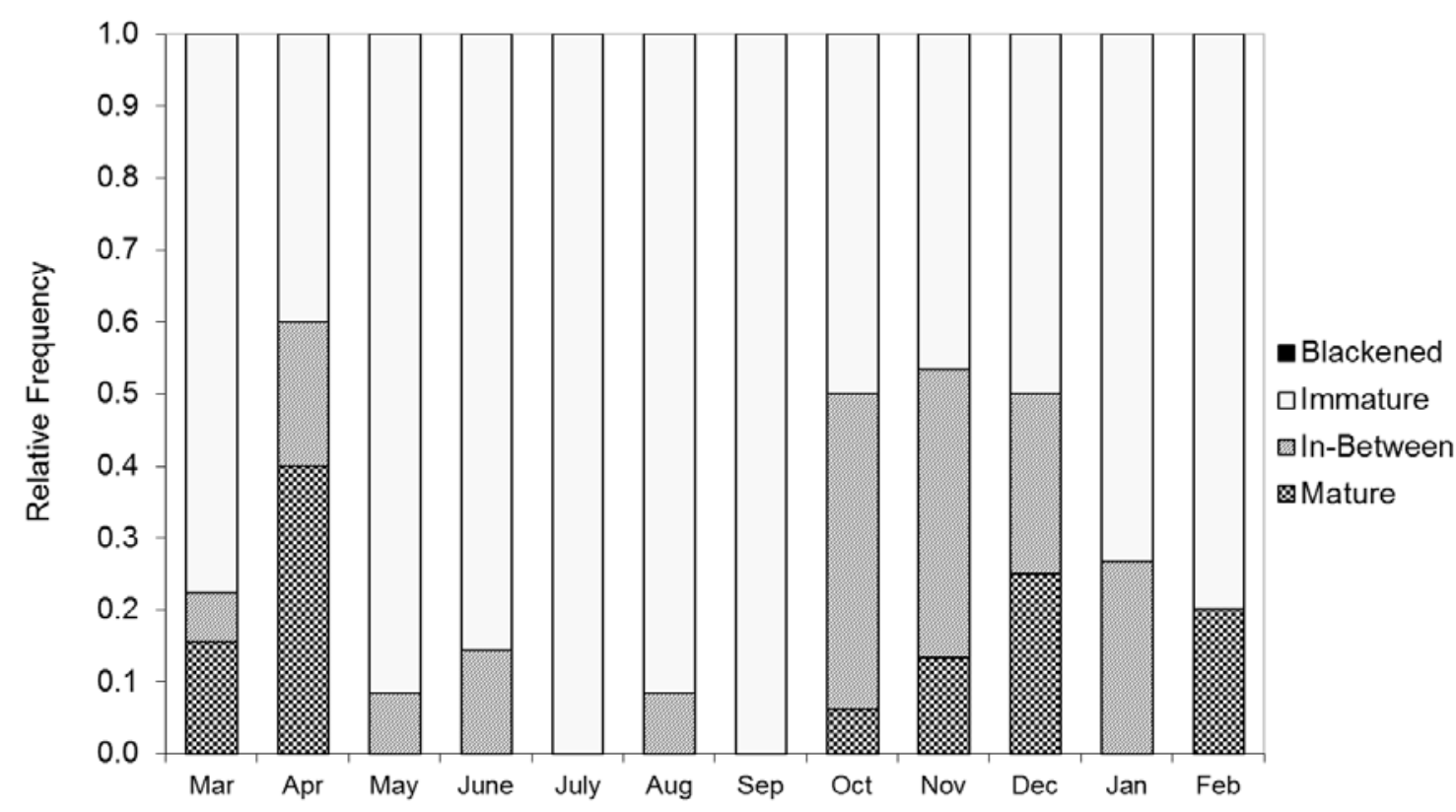

b

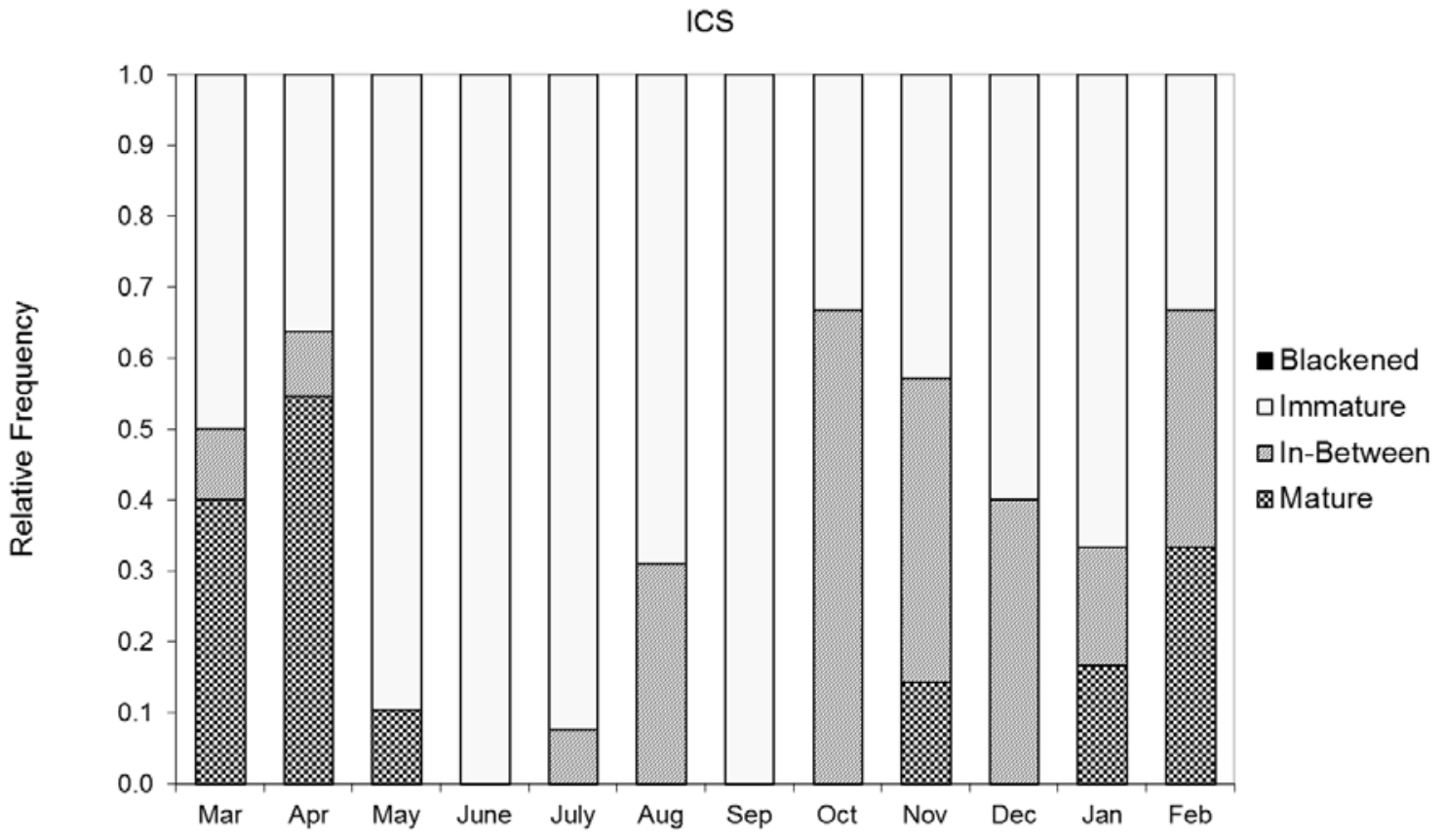

Annual Reproductive Cycle 
C

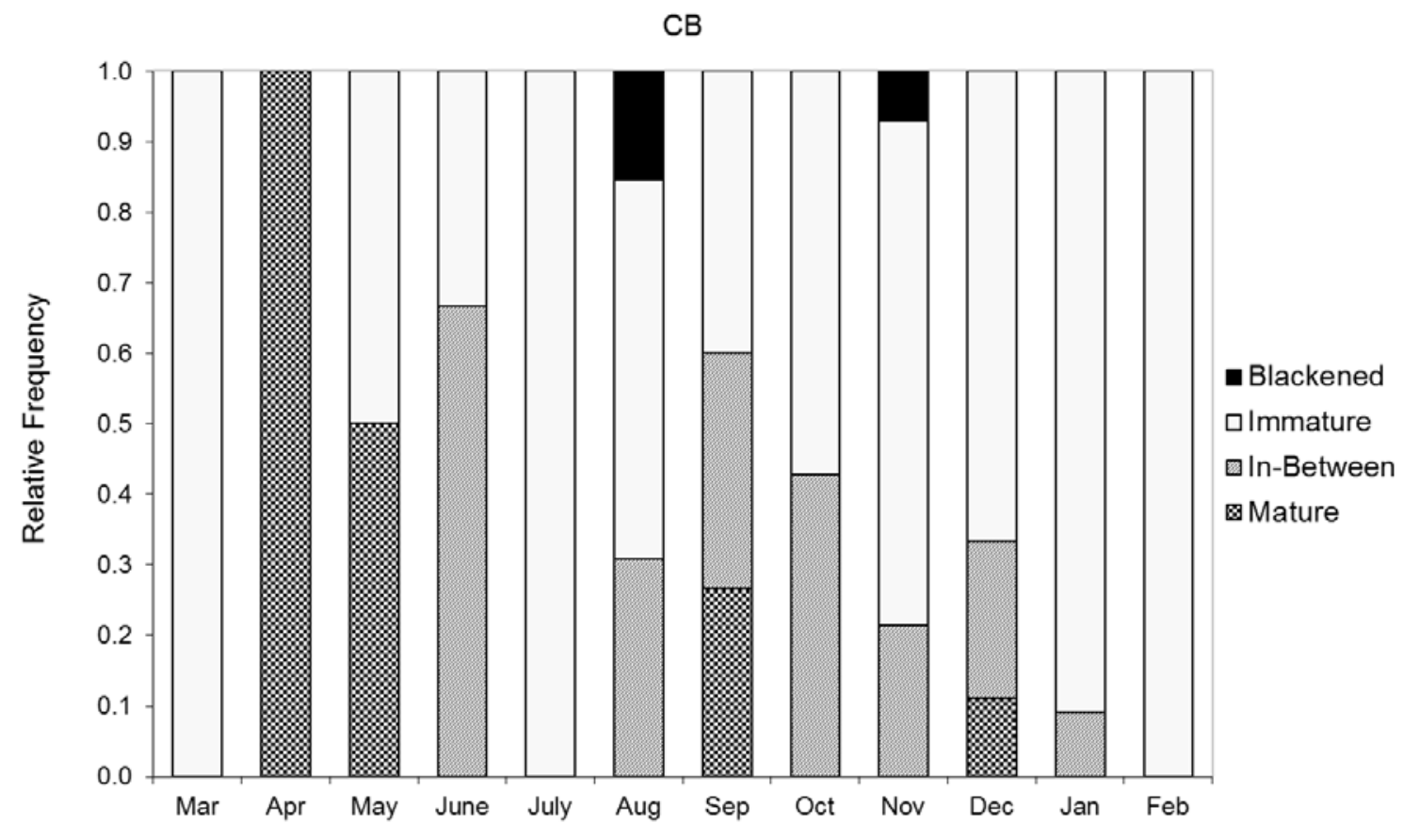

Annual Reproductive Cycle

d

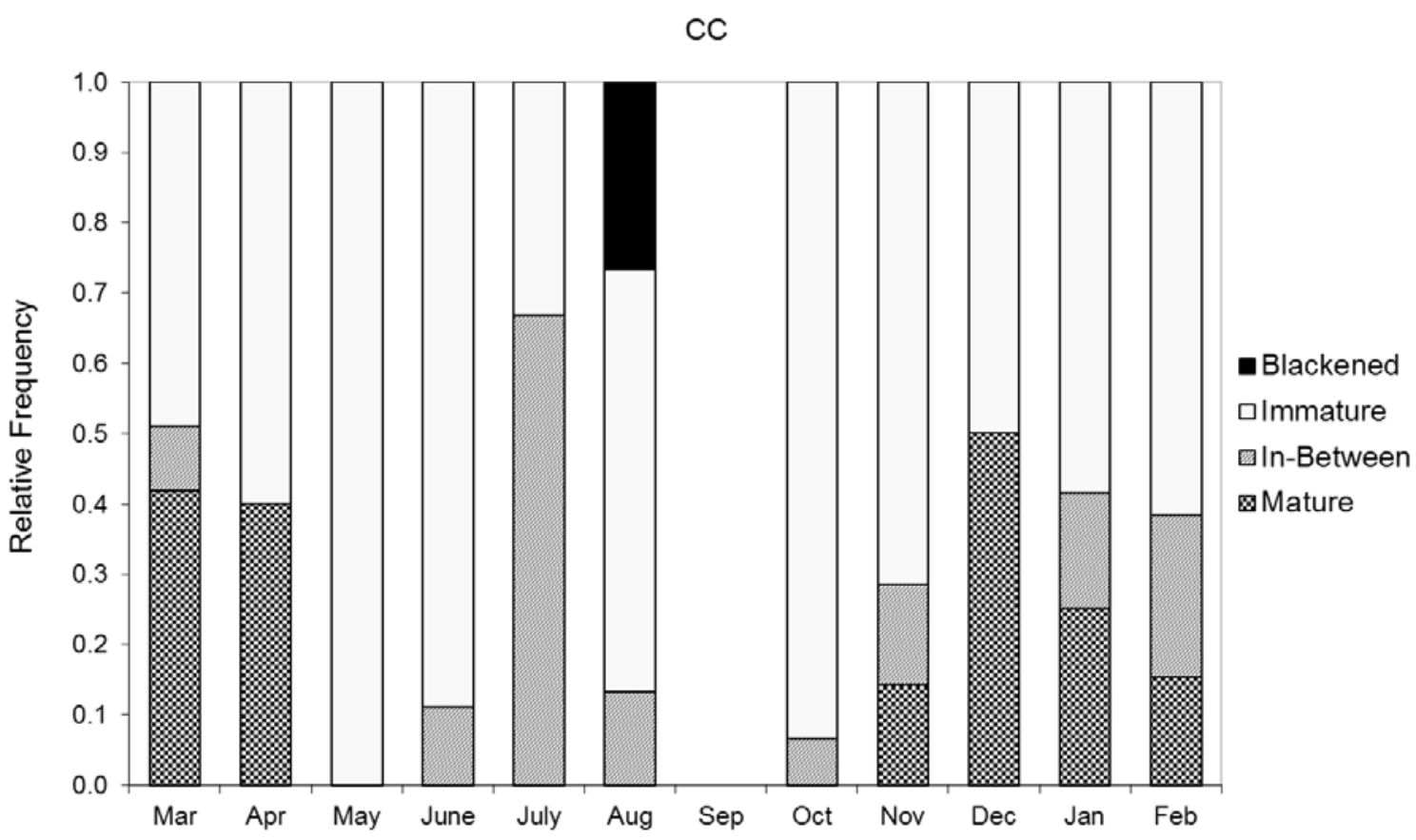

Annual Reproductive Cycle 
Fig. 8. Male creek chub gonadal (testes) somatic index (GSI) at: a) the reference site, Little Indian Creek (LI), b) upper Clear Creek (ICS), c) Conards Branch / Richland Creek (CB) and d) lower Clear Creek (CC). Monthly mean GSIs also presented by category of maturation; mean equates to overall mean for all males analyzed each month. The visual categories of "immature" was very similar in nature to pre-spermatogenic; "in-between" consistently included early- and mid-spermatogenic; and "mature" condition essentially equates to late spermatogenic stage. 
a

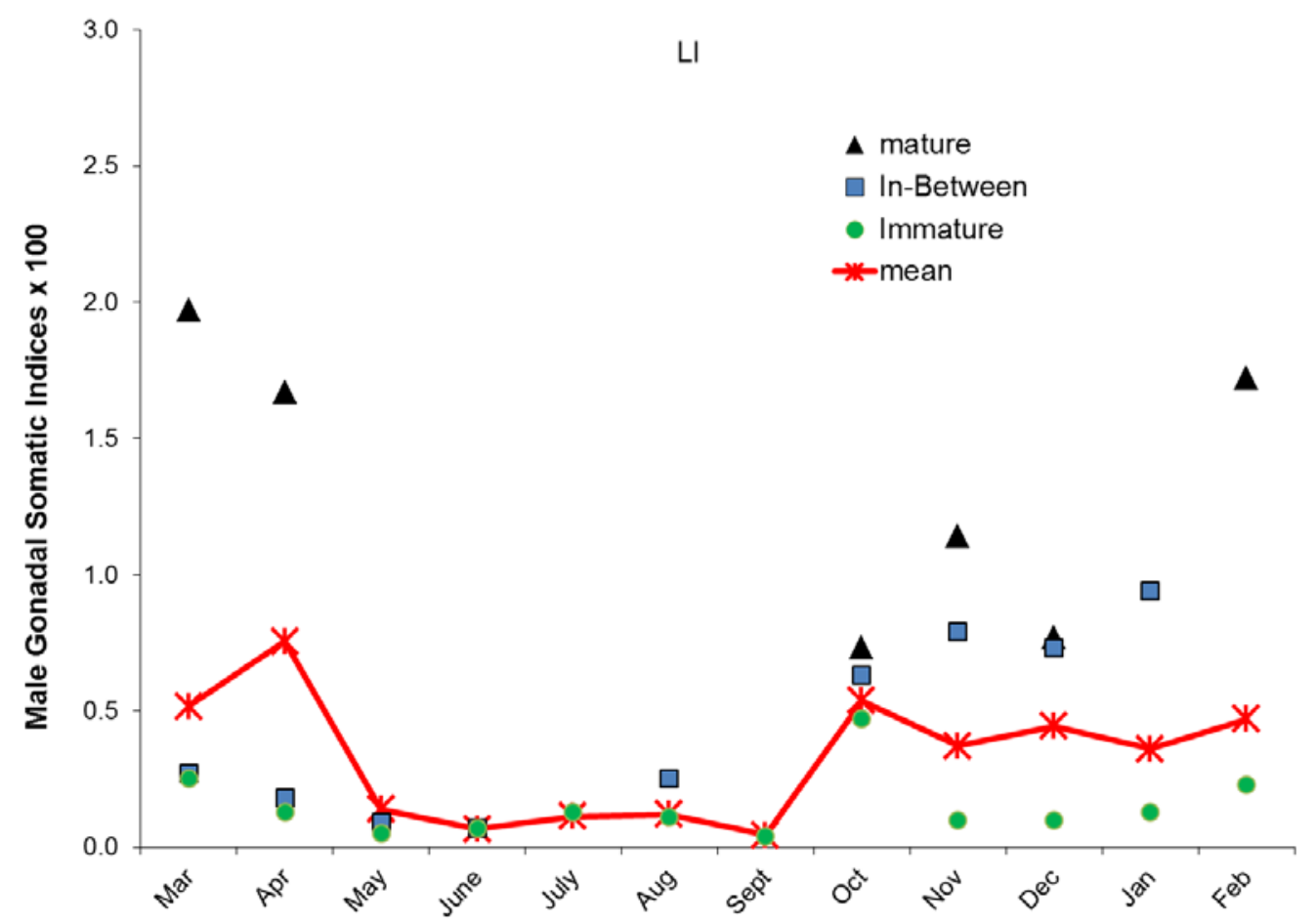

Annual Reproductive Cycle

b

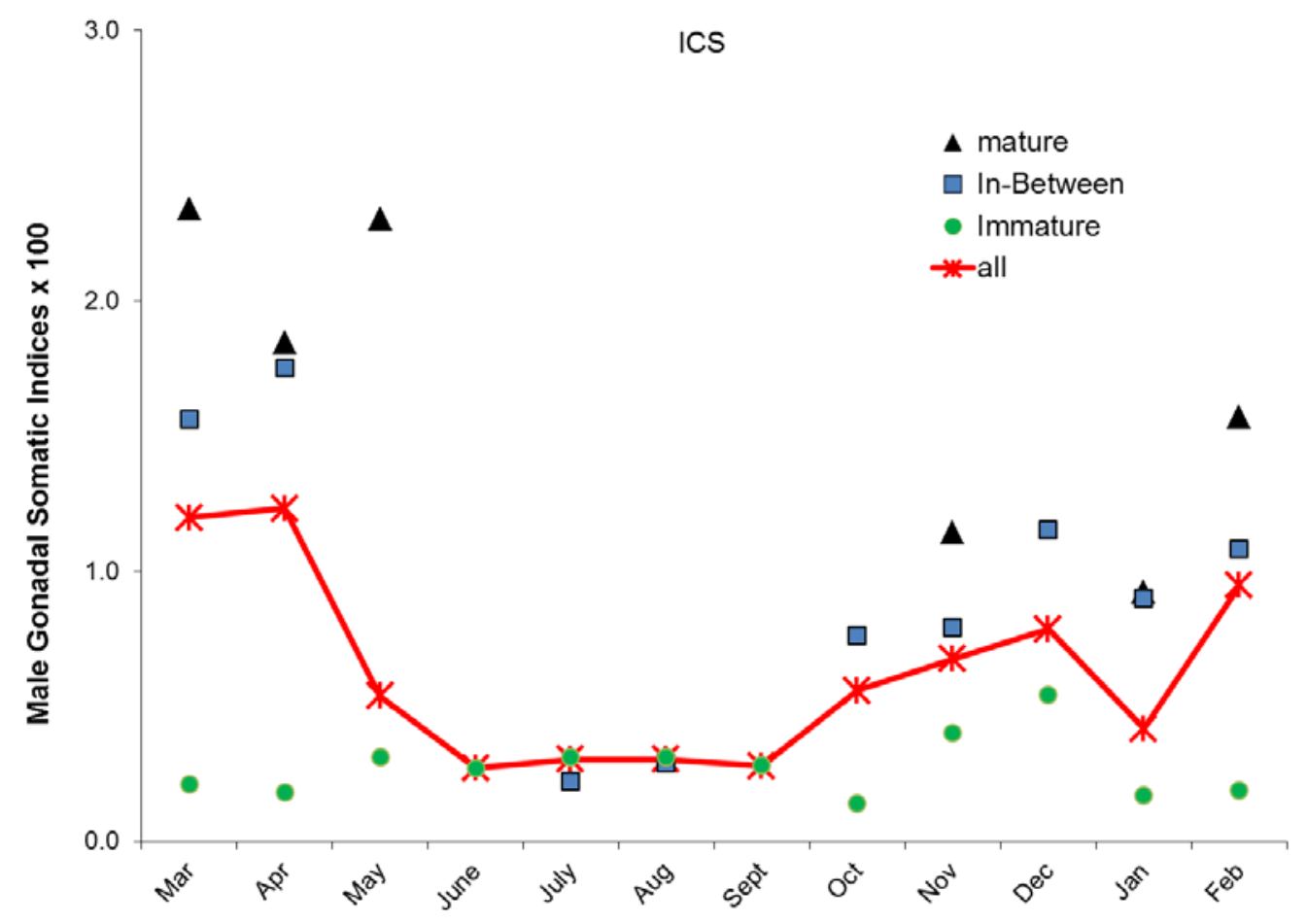

Annual Reproductive Cycle 
C

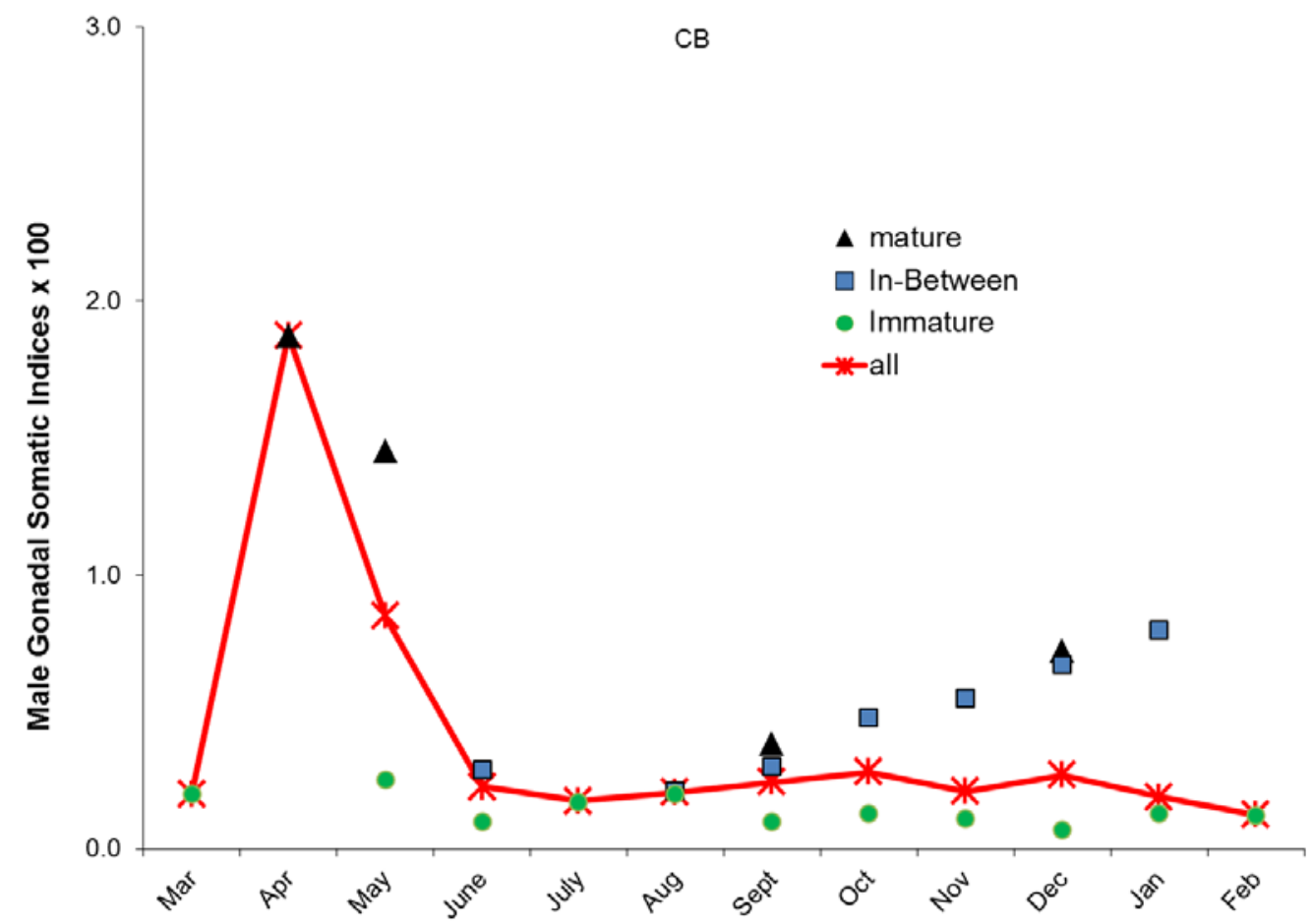

d

Annual Reproductive Cycle

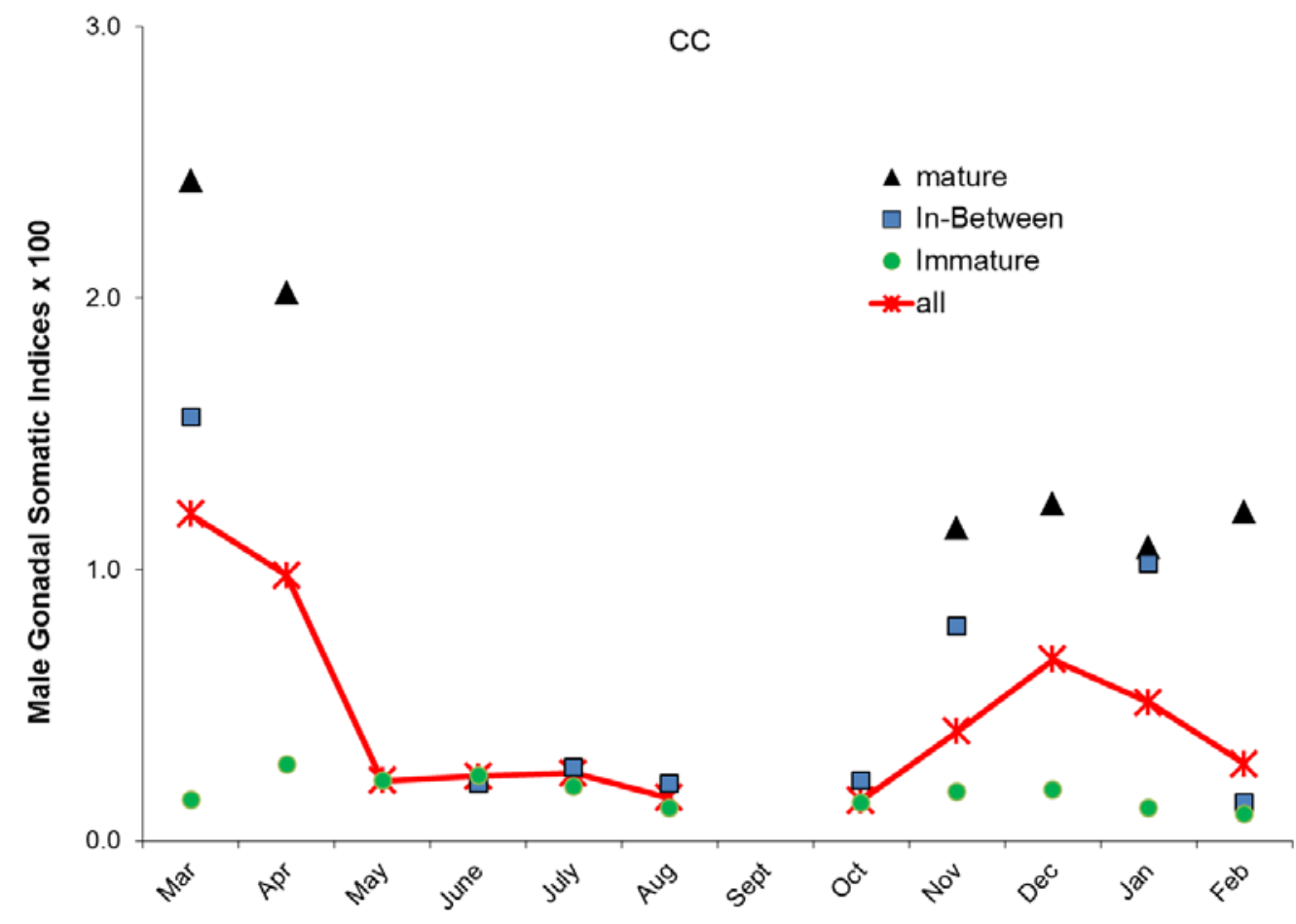

Annual Reproductive Cycle 
Fig. 9. Average male creek chub nuptial tubercle score based on the state of testes maturation at: a) the reference site, Little Indian Creek (LI), b) upper Clear Creek (ICS), c) Conards Branch / Richland Creek (CB) and d) lower Clear Creek (CC). The visual categories of "immature" was very similar in nature to pre-spermatogenic; "in-between" consistently included early- and mid-spermatogenic; and "mature" condition essentially equates to late spermatogenic stage. "Blackened" denotes deteriorating testes of an undetermined nature. 
a

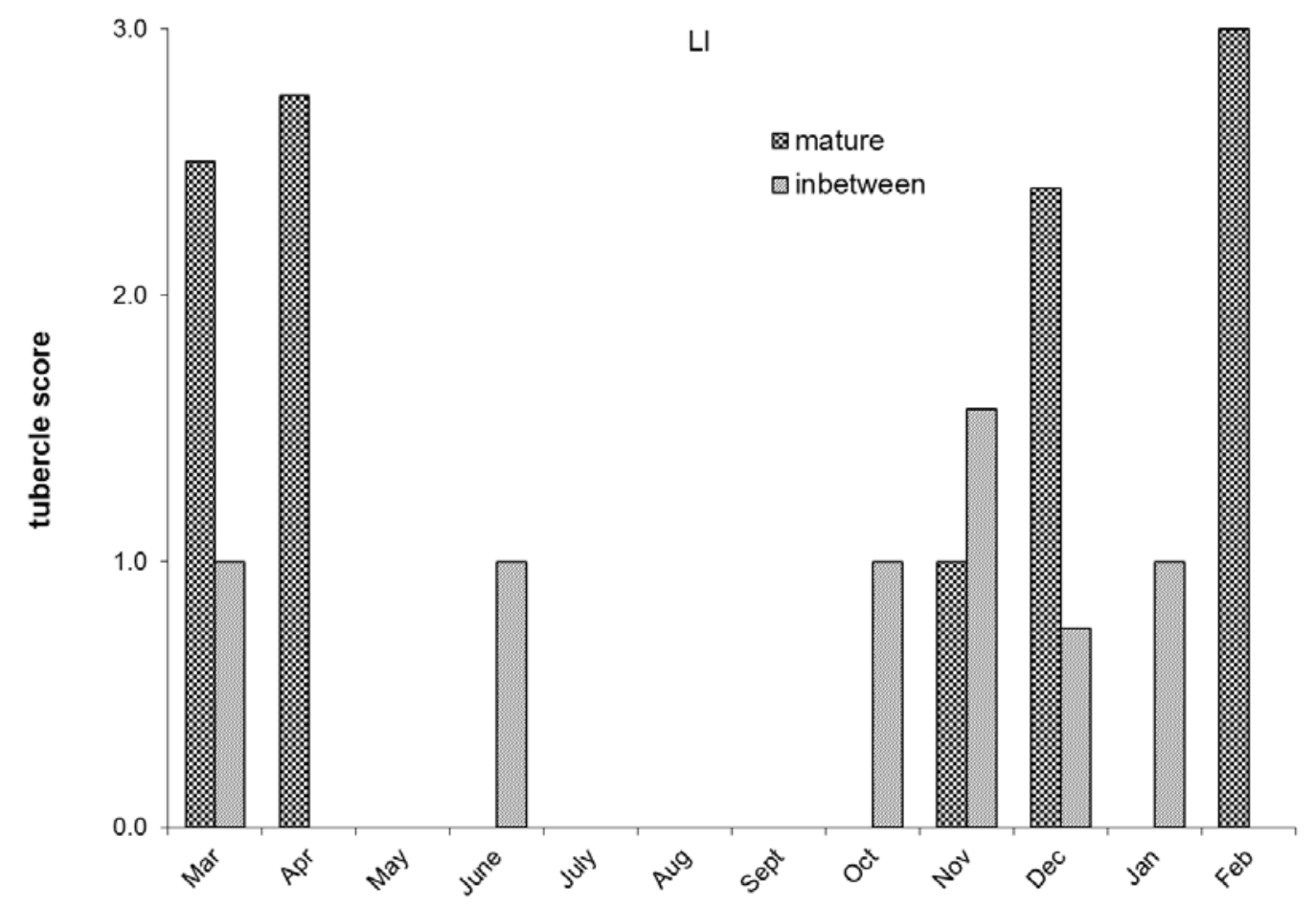

Annual Reproductive Cycle

b

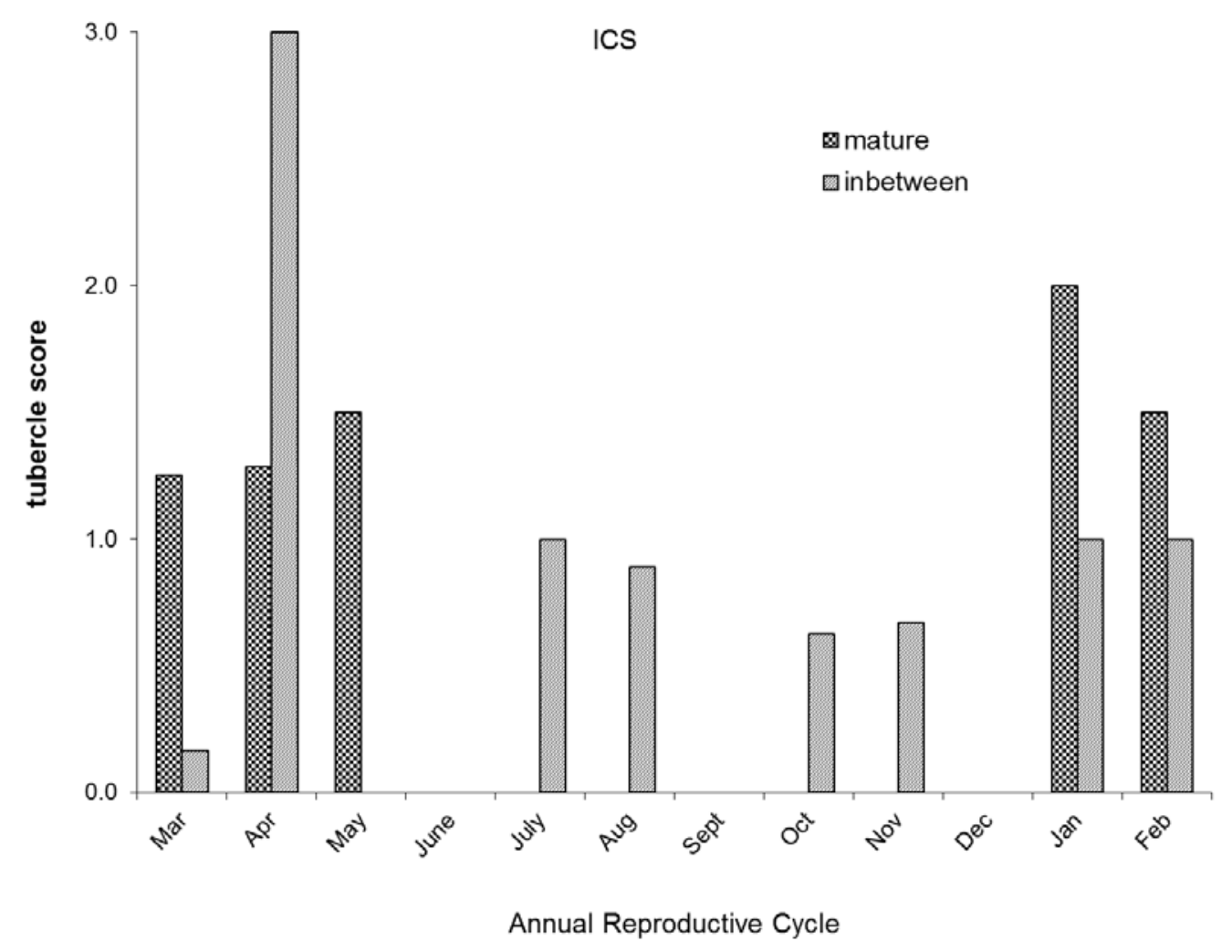


C

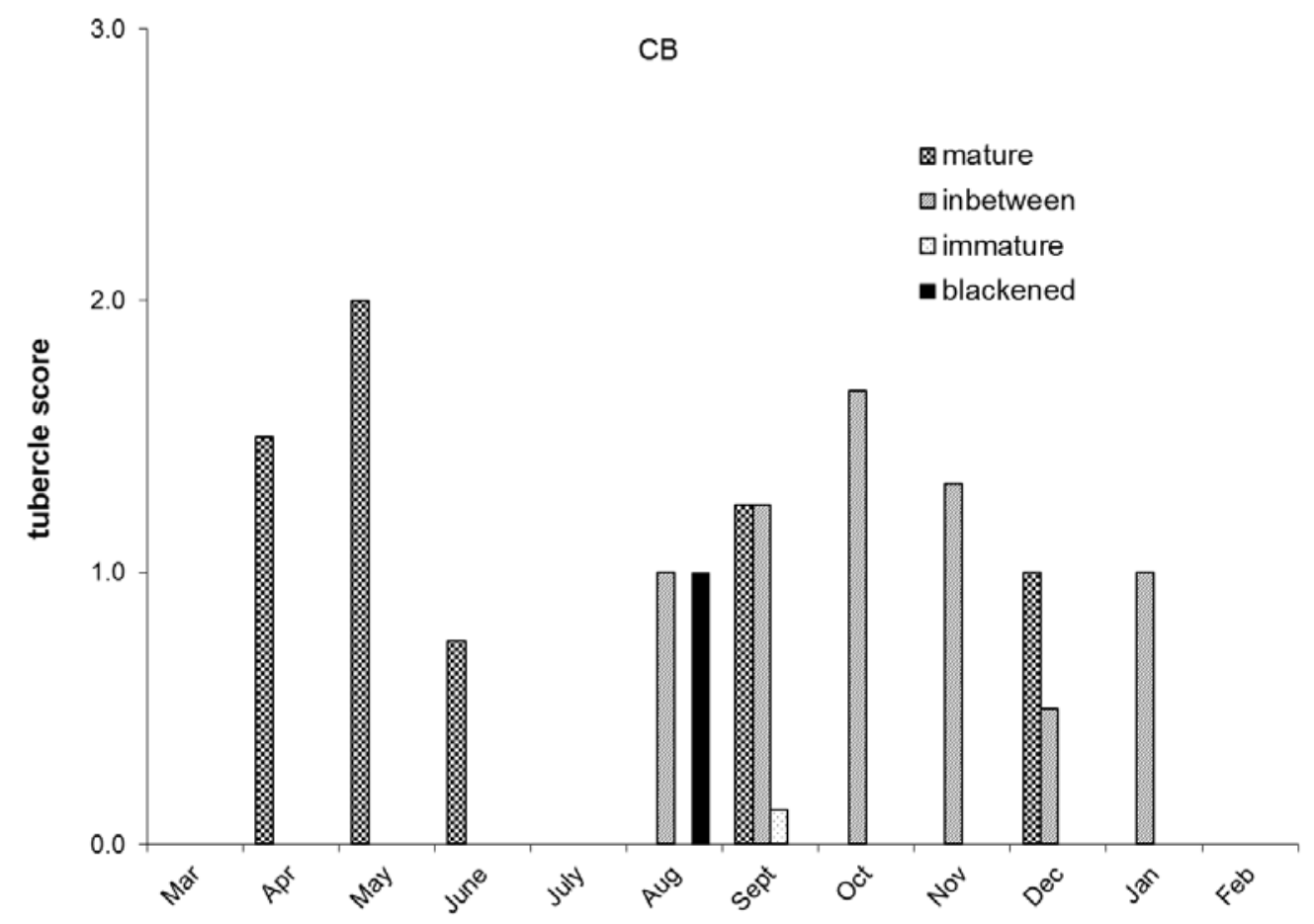

Annual Reproductive Cycle

d

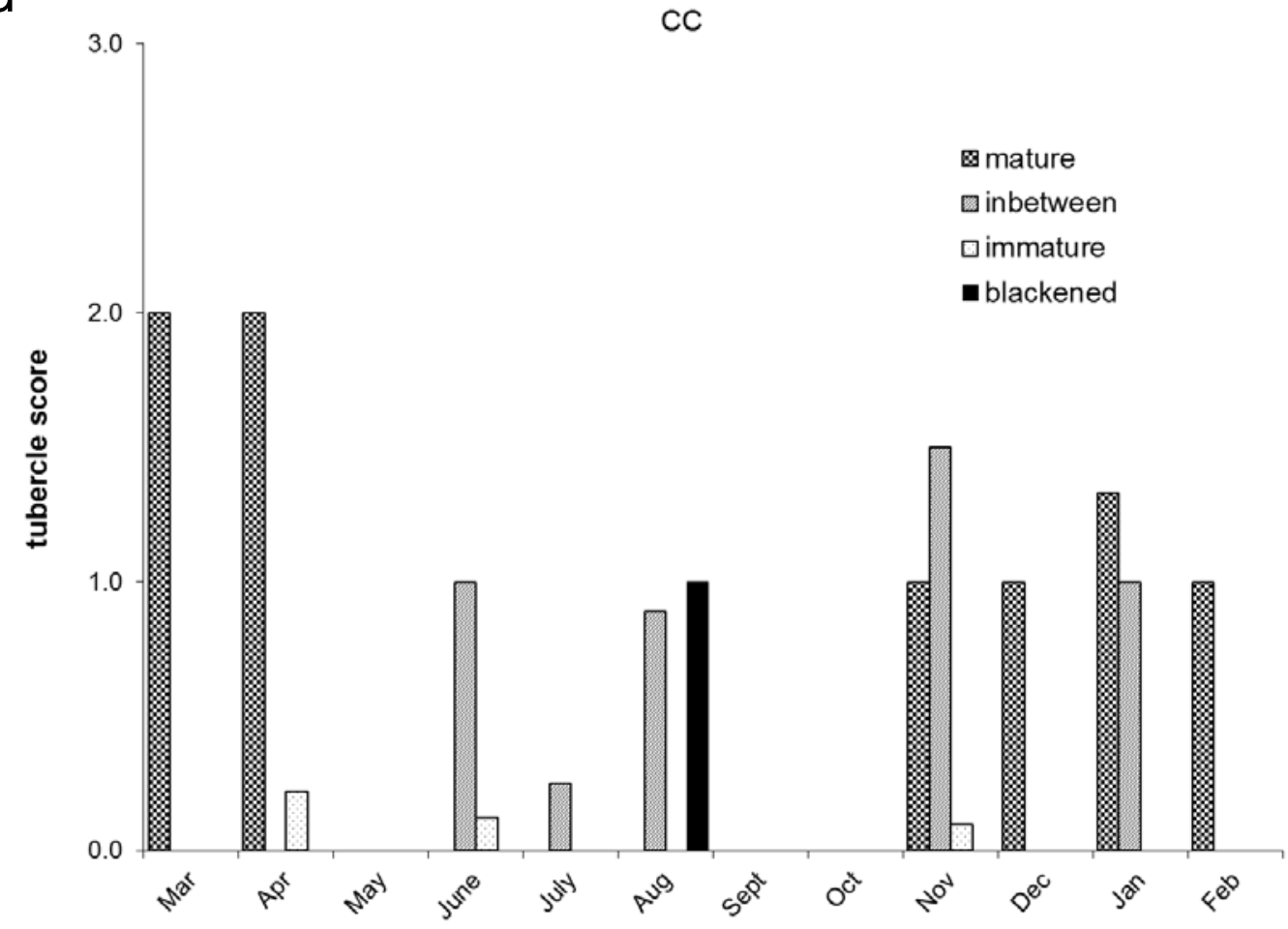

Annual Reproductive Cycle 
Fig. 10. Ratio of testosterone $(T)$ to estradiol $(E)$ in female creek chubs; bars with the same letters are not significantly different at $\alpha=0.05$. High - high contamination levels; lowR - site has been remediated resulting in significant PCB load reductions; Med moderately contaminated; and Ref - reference sites. 


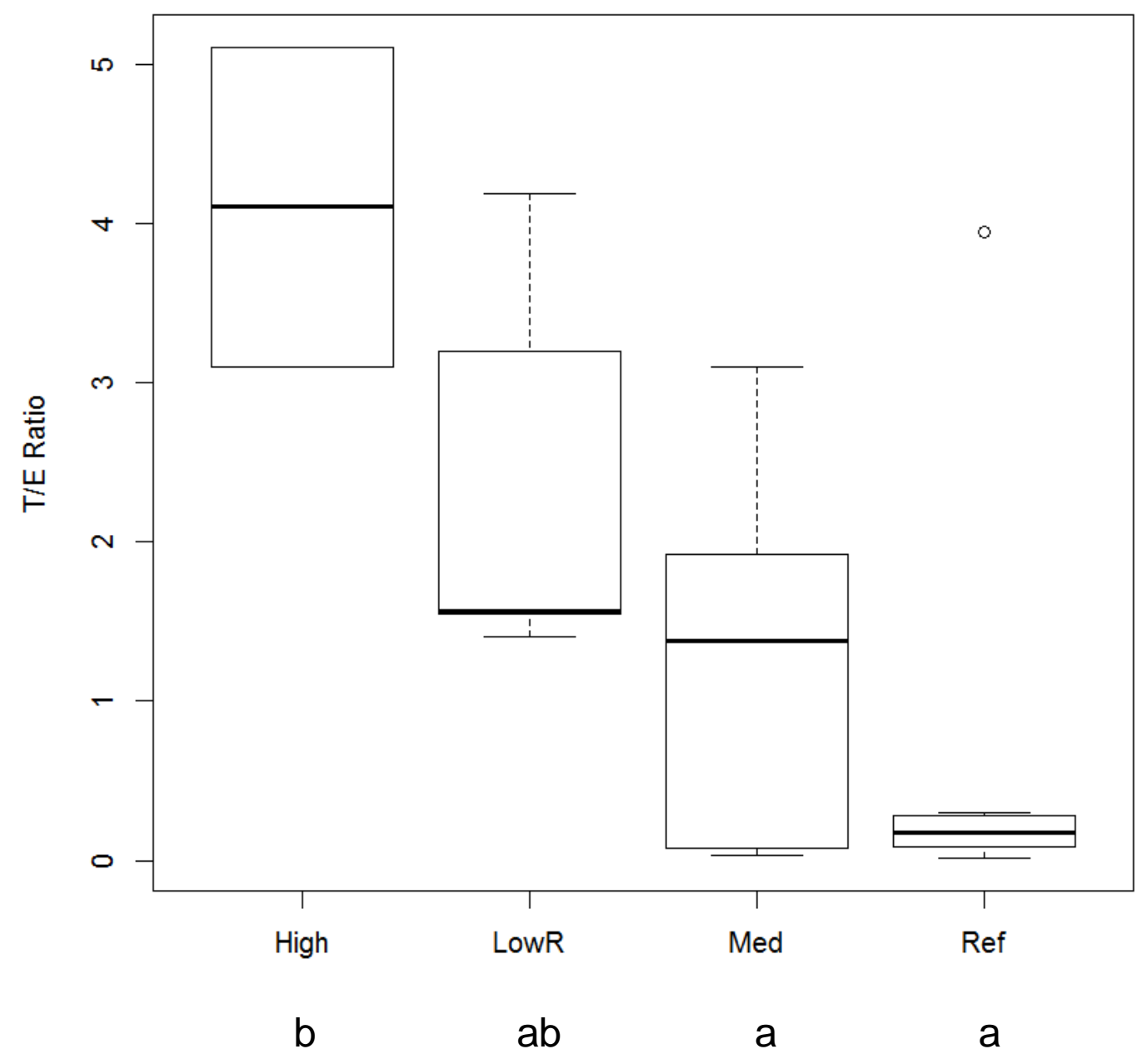

Relative Stream PCB Concentrations 
Table 1. Concentrations of PCBs in whole body creek chub samples $(\mu \mathrm{g} / \mathrm{g}$, wet weight) and sediment $(\mu \mathrm{g} / \mathrm{g}$, dry weight) from seven PCB-contaminated streams: Clear Creek (ICS and CC), Conards Branch / Richland Creek (CB), Stouts Creek (SC), Sinking Creek (ABB) in Monroe County, Pleasant Run Creek (PR) in Lawrence County, the Little Mississenewa River (LM1 and LM2) in Randolph County, and Elliot Ditch / Wea Creek (ED2) in Tippecanoe County, Indiana. Also included are two uncontaminated reference sites: Little Indian Creek (LI), and Brummett Creek (BRUM), Greene and Monroe Counties and a slightly elevated background stream, Burnetts Creek (BC) in Tippecanoe County, Indiana.

\begin{tabular}{|c|c|c|c|c|c|c|c|}
\hline \multirow[b]{2}{*}{ Site } & \multicolumn{3}{|c|}{ Mean whole body PCBs } & \multicolumn{3}{|c|}{ Mean sediment PCBs } & \multirow[b]{2}{*}{$\begin{array}{l}\text { PCB } \\
\text { Grouping }\end{array}$} \\
\hline & $\mu \mathrm{g} / \mathrm{g} \pm \mathrm{SD}$ & $\mathrm{N}$ & $\begin{array}{l}\text { sample } \\
\text { year }\end{array}$ & $\mu g / g \pm S D$ & $\mathrm{~N}$ & $\begin{array}{l}\text { sample } \\
\text { year }\end{array}$ & \\
\hline LI & $0.01 \pm 0.004$ & 6 & 1999 & NA & & & reference \\
\hline $\mathrm{BC}$ & $0.10 \pm 0.09$ & 5 & 2003 & NA & & & reference \\
\hline BRUM & $0.014 \pm 0.002$ & 3 & 2010 & 0.006 & 1 & 2010 & reference \\
\hline LM1 & $13.1 \pm 25$ & 12 & 2001 & $27.7 \pm 5.9$ & 4 & 2002 & lowR \\
\hline PR & $4.2 \pm 1.3$ & 3 & 2009 & & & & lowR \\
\hline SC & $0.9 \pm 0.25$ & 5 & 2003 & & & & lowR \\
\hline SC & $1.26 \pm 0.57$ & 7 & 2004 & $0.17 \pm 0.02$ & 3 & 2004 & lowR \\
\hline ABB & $0.94 \pm 0.34$ & 3 & 2004 & NA & & & medium \\
\hline $\mathrm{CB}$ & $12.1 \pm 3.1$ & 8 & 1998 & $1.9 \pm 0.9$ & 5 & 1998 & medium \\
\hline CB & $0.84 \pm 0.33$ & 6 & 2004 & & & & medium \\
\hline $\mathrm{CC}$ & $0.98 \pm 0.68$ & 10 & 2003 & $0.6 \pm 0.1$ & 3 & 1997 & medium \\
\hline ICS & $19.2 \pm 3.2$ & 9 & 1996 & $2.2 \pm 0.03$ & 5 & 1996 & high \\
\hline ICS & $1.8 \pm 1.0$ & 8 & 2004 & & & & high \\
\hline ED2 & $5.3 \pm 2.8$ & 4 & 2001 & $0.53 \pm 0.05$ & 3 & 2011 & high \\
\hline LM1 & 15.0 & $1^{a}$ & 1993 & & & & high \\
\hline LM2 & $24.8 \pm 10.2$ & 10 & 2001 & $3.4 \pm 2.2$ & 5 & 2002 & high \\
\hline LM2 & $5.9 \pm 3.2$ & 4 & 2003 & & & & high \\
\hline PR & $359 \pm 87$ & 6 & 2001 & $7.1 \pm 1.5$ & 14 & 2001 & high \\
\hline
\end{tabular}

$\mathrm{N}$ - number of samples; SD - standard deviation; Reference - reference site; lowR - site has been remediated resulting in significant PCB load reductions; medium - moderately contaminated; high - high contamination levels. ${ }^{a}$ - composite of 15. 
Table 2. Female ovary condition and gonadal somatic index (GSI) for Little Indian Creek (LI) across each month of the year.

\begin{tabular}{|c|c|c|c|c|c|c|c|c|c|c|}
\hline & $\mathrm{N}$ & $\begin{array}{l}\text { Monthly } \\
\text { mean } \\
\text { GSI }\end{array}$ & $\begin{array}{c}\text { Mature } \\
\text { GSI }\end{array}$ & $\begin{array}{c}\text { Mature } \\
\%\end{array}$ & $\begin{array}{l}\text { Late } \\
\text { Maturing } \\
\text { GSI }\end{array}$ & $\begin{array}{c}\text { Late } \\
\text { Maturing } \\
\%\end{array}$ & $\begin{array}{l}\text { Latent / } \\
\text { Early } \\
\text { Maturing } \\
\text { GSI }\end{array}$ & $\begin{array}{c}\text { Latent / } \\
\text { Early } \\
\text { Maturing } \\
\%\end{array}$ & $\begin{array}{c}\text { Atretic } \\
\text { GSI }\end{array}$ & $\begin{array}{c}\text { Atretic } \\
\%\end{array}$ \\
\hline January & 6 & 6.96 & & 0 & 6.01 & 100.0 & & 0 & & 0 \\
\hline February & 2 & 9.19 & & 0 & 9.19 & 100.0 & & 0 & & 0 \\
\hline March & 8 & 14.09 & 20.32 & 50.0 & 10.07 & 37.5 & 1.22 & 12.5 & & 0 \\
\hline April & 12 & 9.88 & 13.61 & 50.0 & 7.15 & 41.7 & 1.15 & 8.3 & & 0 \\
\hline May & 19 & 1.69 & 8.23 & 5.3 & 4.55 & 15.8 & 0.68 & 78.9 & & 0 \\
\hline June & 6 & 0.82 & & 0 & 1.27 & 16.7 & 0.72 & 83.3 & & 0 \\
\hline July & 2 & 0.59 & & 0 & & 0 & 0.59 & 100.0 & & 0 \\
\hline August & 7 & 1.34 & & 0 & & 0 & 1.34 & 100.0 & & 0 \\
\hline September & 1 & 3.42 & & 0 & 3.42 & 100.0 & & 0 & & 0 \\
\hline October & 7 & 4.21 & & 0 & 4.21 & 100.0 & & 0 & & 0 \\
\hline November & 11 & 4.85 & & 0 & 4.85 & 100.0 & & 0 & & 0 \\
\hline December & 7 & 5.90 & & 0 & 5.90 & 100.0 & & 0 & & 0 \\
\hline
\end{tabular}


Table 3. Female ovary condition and gonadal somatic index (GSI) for upper Clear Creek (ICS) across each month of the year.

\begin{tabular}{|c|c|c|c|c|c|c|c|c|c|c|}
\hline & $\mathrm{N}$ & $\begin{array}{l}\text { Monthly } \\
\text { mean } \\
\text { GSI }\end{array}$ & $\begin{array}{c}\text { Mature } \\
\text { GSI }\end{array}$ & $\begin{array}{c}\text { Mature } \\
\%\end{array}$ & $\begin{array}{c}\text { Late } \\
\text { Maturing } \\
\text { GSI }\end{array}$ & $\begin{array}{c}\text { Late } \\
\text { Maturing } \\
\%\end{array}$ & $\begin{array}{c}\text { Latent / } \\
\text { Early } \\
\text { Maturing } \\
\text { GSI }\end{array}$ & $\begin{array}{c}\text { Latent / } \\
\text { Early } \\
\text { Maturing } \\
\%\end{array}$ & $\begin{array}{c}\text { Atretic } \\
\text { GSI }\end{array}$ & $\begin{array}{c}\text { Atretic } \\
\%\end{array}$ \\
\hline January & 8 & 6.61 & & 0 & 6.61 & 100.0 & & 0 & & 0 \\
\hline February & 16 & 7.85 & 10.63 & 18.8 & 7.72 & 75.0 & & 0 & 1.07 & 6.3 \\
\hline March & 7 & 12.08 & 17.16 & 42.9 & 8.28 & 57.1 & & 0 & & 0 \\
\hline April & 10 & 13.48 & 16.08 & 60.0 & 9.58 & 40.0 & & 0 & & 0 \\
\hline May & 25 & 7.03 & 18.78 & 28.0 & 4.96 & 16.0 & 1.74 & 56.0 & & 0 \\
\hline June & 14 & 5.47 & 14.54 & 21.4 & 4.86 & 35.7 & 1.45 & 42.9 & & 0 \\
\hline July & 18 & 2.38 & 7.78 & 11.1 & 1.92 & 22.2 & 1.63 & 66.7 & & 0 \\
\hline August & 34 & 1.66 & & 0 & & 0 & 1.67 & 94.1 & 1.57 & 5.9 \\
\hline September & 8 & 2.37 & & 0 & 2.08 & 25.0 & 2.12 & 75.0 & & 0 \\
\hline October & 18 & 4.94 & & 0 & 5.09 & 94.4 & 2.27 & 5.6 & & 0 \\
\hline November & 17 & 5.35 & & 0 & 5.90 & 88.2 & 1.28 & 11.8 & & 0 \\
\hline December & 16 & 5.74 & & 0 & 6.51 & 87.5 & 0.34 & 12.5 & & 0 \\
\hline
\end{tabular}


Table 4. Female ovary condition and gonadal somatic index (GSI) for Conards Branch (CB) across each month of the year.

\begin{tabular}{|c|c|c|c|c|c|c|c|c|c|c|}
\hline & $\mathrm{N}$ & $\begin{array}{c}\text { Monthly } \\
\text { mean } \\
\text { GSI }\end{array}$ & $\begin{array}{c}\text { Mature } \\
\text { GSI }\end{array}$ & $\begin{array}{c}\text { Mature } \\
\%\end{array}$ & $\begin{array}{c}\text { Late } \\
\text { Maturing } \\
\text { GSI }\end{array}$ & $\begin{array}{c}\text { Late } \\
\text { Maturing } \\
\%\end{array}$ & $\begin{array}{l}\text { Latent / } \\
\text { Early } \\
\text { Maturing } \\
\text { GSI }\end{array}$ & $\begin{array}{c}\text { Latent / } \\
\text { Early } \\
\text { Maturing } \\
\%\end{array}$ & $\begin{array}{c}\text { Atretic } \\
\text { GSI }\end{array}$ & $\begin{array}{c}\text { Atretic } \\
\%\end{array}$ \\
\hline January & 10 & 5.26 & & 0 & 6.40 & 80.0 & 0.74 & 20.0 & & 0 \\
\hline February & 12 & 5.47 & & 0 & 7.03 & 75.0 & 0.80 & 25.0 & & 0 \\
\hline March & 8 & 3.22 & & 0 & 10.57 & 25.0 & 0.77 & 75.0 & & 0 \\
\hline April & 4 & 7.16 & 24.9 & 25.0 & & 0 & 1.26 & 75.0 & & 0 \\
\hline May & 9 & 7.96 & 21.6 & 33.3 & & 0 & 1.15 & 66.7 & & 0 \\
\hline June & 7 & 2.52 & 6.1 & 14.3 & & 0 & 1.93 & 85.7 & & 0 \\
\hline July & 8 & 1.06 & & 0 & & 0 & 1.06 & 100.0 & & 0 \\
\hline August & 10 & 1.26 & & 0 & & 0 & 1.26 & 100.0 & & 0 \\
\hline September & 8 & 2.74 & & 0 & 3.14 & 62.5 & 2.08 & 37.5 & & 0 \\
\hline October & 14 & 3.69 & & 0 & 3.63 & 79.0 & 0.73 & 14.3 & 4.39 & 7.1 \\
\hline November & 9 & 3.92 & & 0 & 4.51 & 67.0 & 2.17 & 22.2 & 3.88 & 11.1 \\
\hline December & 11 & 5.69 & & 0 & 5.69 & 91.0 & & 0 & & $0^{\mathrm{a}}$ \\
\hline
\end{tabular}

a - 1 of 11 females in December did not have ova contained in an ovary, rather ova were attached throughout the body cavity. 
Table 5. Female ovary condition and gonadal somatic index (GSI) for lower Clear Creek (CC) across each month of the year.

\begin{tabular}{lcccccccccc}
\hline & & $\begin{array}{c}\text { Monthly } \\
\text { mean } \\
\text { GSI }\end{array}$ & $\begin{array}{c}\text { Mature } \\
\text { GSI }\end{array}$ & $\begin{array}{c}\text { Mature } \\
\%\end{array}$ & $\begin{array}{c}\text { Late } \\
\text { Maturing } \\
\text { GSI }\end{array}$ & $\begin{array}{c}\text { Late } \\
\text { Maturing } \\
\%\end{array}$ & $\begin{array}{c}\text { Latent } / \\
\text { Early } \\
\text { Maturing } \\
\text { GSI }\end{array}$ & $\begin{array}{c}\text { Latent } / \\
\text { Early } \\
\text { Maturing } \\
\%\end{array}$ & $\begin{array}{c}\text { Atretic } \\
\text { GSI }\end{array}$ & $\begin{array}{c}\text { Atretic } \\
\%\end{array}$ \\
\hline January & 8 & 6.86 & & 0 & 6.86 & 100.0 & & 0 & 0 \\
February & 7 & 6.96 & & 0 & 6.96 & 100.0 & & 0 & 0 \\
March & 9 & 9.49 & 17.6 & 33.3 & 9.94 & 33.3 & 0.94 & 33.3 & 0 \\
April & 4 & 11.4 & 13.9 & 50.0 & 8.91 & 50.0 & & 0 & 0 \\
May & 11 & 3.50 & & 0 & 11.8 & 18.2 & 1.66 & 81.8 & & 0 \\
June & 13 & 1.39 & & 0 & & 0 & 1.39 & 100.0 & & 0 \\
July & 8 & 1.69 & & 0 & & 0 & 1.32 & 37.5 & 1.91 & 62.5 \\
August & 14 & 1.47 & & 0 & & 0 & 1.45 & 92.9 & 1.75 & 7.1 \\
September & 0 & & & & & & & & & 0 \\
October & 17 & 5.32 & & 0 & 5.32 & 100.0 & & & \\
November & 9 & 4.45 & & 0 & 6.20 & 66.7 & 0.96 & 33.3 & & 0 \\
December & 6 & 6.88 & & 0 & 8.04 & 83.3 & 1.07 & 16.7 & & 0 \\
\hline
\end{tabular}


Table 6. Average oocyte diameter by stage and age in $\mathrm{mm} \pm \mathrm{SD}(\mathrm{n}=$ number of adult females sampled $)$

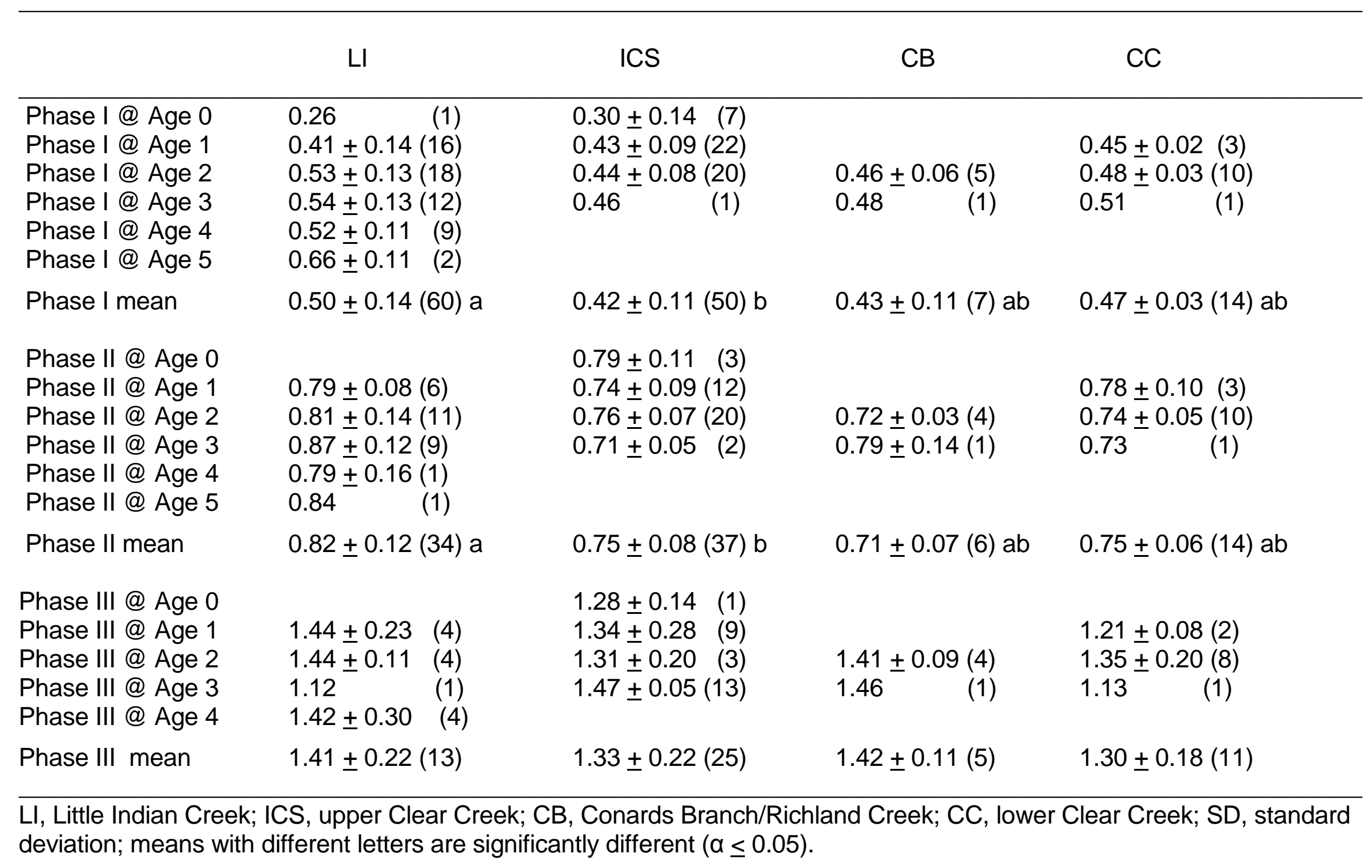


Table 7. Average oocyte diameter by stage and season in $\mathrm{mm} \pm \mathrm{SD}(\mathrm{n}=$ number of adult females sampled $)$

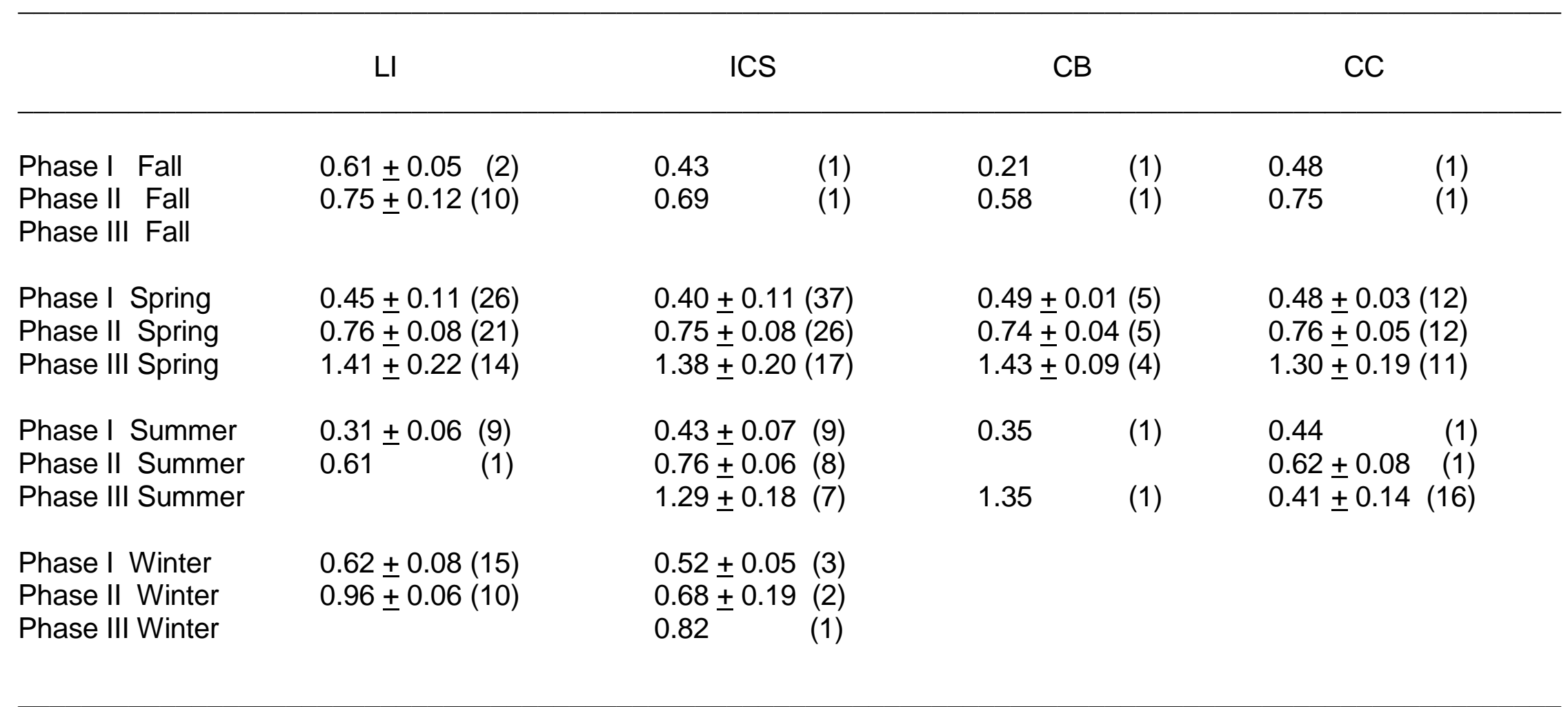

LI, Little Indian Creek; ICS, upper Clear Creek; CB, Conards Branch/Richland Creek; CC, lower Clear Creek; SD, standard deviation 
Table 8. Summary of creek chub fecundity from the literature and including Little Indian Creek, Monroe County, Indiana.

\begin{tabular}{|c|c|c|c|c|}
\hline State & $\begin{array}{l}\text { TL } \\
(\mathrm{mm})\end{array}$ & $\begin{array}{l}\text { total } \\
\text { fecundity }\end{array}$ & comments & Reference \\
\hline Ohio & $\begin{array}{l}114 \\
120\end{array}$ & $\begin{array}{l}4,193 \\
4,671\end{array}$ & $\begin{array}{l}\text { includes } 106 \text { Phase I } \\
\text { includes } 183 \text { Phase I }\end{array}$ & Clark (1943) \\
\hline New York & $\begin{array}{l}101 \\
140\end{array}$ & $\begin{array}{l}2,820 \\
4,042\end{array}$ & & Greeley (1930) \\
\hline Manitoba & $\min$ & $\begin{array}{l}1,146 \\
7,539\end{array}$ & & $\begin{array}{l}\text { Moshenko \& } \\
\text { Gee (1973) }\end{array}$ \\
\hline Illinois & $\begin{array}{l}\min \\
\max \end{array}$ & $\begin{array}{c}438 \\
7,143\end{array}$ & & Schemske (1974) \\
\hline $\begin{array}{l}\text { hatchery } \\
\text { conditions }\end{array}$ & $\begin{array}{l}127 \\
152\end{array}$ & $\begin{array}{l}3,500 \\
5,000\end{array}$ & $\begin{array}{l}\text { mean }(n=16) \\
\text { mean }(n=12)\end{array}$ & Washburn (1948) \\
\hline Indiana (LI) & $\begin{array}{c}64 \\
199\end{array}$ & $\begin{array}{c}34 \\
22,623\end{array}$ & $\begin{array}{l}\text { 13-month old } \\
\text { 80-month old }\end{array}$ & this study \\
\hline
\end{tabular}

$\mathrm{TL}$, total length in mm; LI, Little Indian Creek; min, smallest female with ova to count; max, largest female captured 
Table 9. Regression equations for creek chub total fecundity versus age in months

Site total fecundity $\quad \mathrm{N}^{\mathrm{a}}$

$\begin{array}{lrlll}\mathrm{LI}^{\mathrm{b}} & 216.6 * \text { months }-2,630\left(\mathrm{p}<0.0001 ; \mathrm{R}^{2}=0.56\right) & \mathrm{A}^{\mathrm{c}} & 94 \\ \mathrm{ICS}^{\mathrm{d}} & 96.7 * \text { months }-268\left(\mathrm{p}<0.0001 ; \mathrm{R}^{2}=0.32\right) & \mathrm{B} & 90 \\ \mathrm{CB}^{\mathrm{e}} & 101.1 * \text { months }-1,287\left(\mathrm{p}<0.003 ; \mathrm{R}^{2}=0.26\right) & \mathrm{B} & 28 \\ \mathrm{CC}^{f} & 176.1 * \text { months }-2,247\left(\mathrm{p}<0.0001 ; \mathrm{R}^{2}=0.45\right) & \mathrm{A} & 48\end{array}$

$\mathrm{a}-\mathrm{N}$, number of fish included in regression.

b - LI, Little Indian Creek.

${ }^{c}$ - Regression lines with different letters were significantly different $(\alpha \leq 0.05)$.

d - ICS, upper Clear Creek.

e - CB, Conards Branch/Richland Creek.

f - CC, lower Clear Creek. 
Table 10. Evaluation of histologically determined testes spermatogenic status and gross visual testes condition assessment schemes in comparison to testes gonadal somatic indices [GSI \pm SD (n)]. Site specific means with different letters are significantly different $(\alpha \leq 0.05)$.

\begin{tabular}{llll}
\hline $\mathrm{LI}$ & $\mathrm{ICS}$ & $\mathrm{CB}$ & $\mathrm{CC}$ \\
\hline
\end{tabular}

GSI by spermatogenic status

\begin{tabular}{|c|c|c|c|c|}
\hline pre & $0.18 \pm 0.08$ (5) a & $0.39 \pm 0.39$ (3) $a$ & $0.34 \pm 0.17(12) a$ & $0.35 \pm 0.17$ (4) $\mathrm{a}$ \\
\hline early & $0.79 \pm 0.36$ (10) b & $0.94 \pm 0.18(9) \mathrm{ab}$ & $0.63 \pm 0.30(9) \mathrm{ac}$ & $1.49 \pm 0.65$ (19) b \\
\hline mid & $0.93 \pm 0.37$ (8) b & $1.51 \pm 0.43(3) b c$ & $1.78 \quad$ (1) bc & na \\
\hline late & $1.77 \pm 0.53$ (6) $c$ & $2.10 \pm 0.45(9) c$ & $1.43 \pm 0.63(6) b$ & $1.96 \pm 0.36(6) b$ \\
\hline spent & nā & nā & $0.37^{-} \quad$ (1) $a b$ & nā \\
\hline$p$-value & $<1.0 \mathrm{e}-5$ & $<1.0 \mathrm{e}-6$ & $<1.0 \mathrm{e}-4$ & 0.0001 \\
\hline
\end{tabular}

GSI by visual condition

$\begin{array}{lcccc}\text { immature } & 0.18 \pm 0.08(5) \mathrm{a} & 0.17 \pm 0.08(2) \mathrm{a} & 0.13 \pm 0.01(2) \mathrm{ab} & 0.47 \pm 0.18(2) \mathrm{a} \\ \text { inbetween } & 0.74 \pm 0.20(12) \mathrm{b} & 1.05 \pm 0.38(9) \mathrm{a} & 0.55 \pm 0.39(20) \mathrm{a} & 0.63 \pm 0.46(4) \mathrm{a} \\ \text { mature } & 1.42 \pm 0.61(12) \mathrm{c} & 1.79 \pm 0.63(13) \mathrm{b} & 1.07 \pm 0.73(9) \mathrm{b} & 1.66 \pm 0.62(23) \mathrm{b} \\ \text { blackened } & \text { na } & \text { na } & \text { na } & 0.20 \pm 0.04(2) \mathrm{a} \\ \text { p-value } & <1.0 \mathrm{e}-4 & <5.0 \mathrm{e}-4 & 0.01 & 0.0004\end{array}$

LI, Little Indian Creek; ICS, upper Clear Creek; CB, Conards Branch/Richland Creek; CC, lower Clear Creek; SD - standard deviation; (n), number of animals; na, none available in that category 
Table 11. Evaluation of histologically determined testes spermatogenic status and gross visual testes condition assessment schemes in comparison to tubercle status classification [ \pm SD $(n)$ ]. Site specific means with different letters are significantly different $(\alpha \leq 0.05)$.

LI ICS $\quad$ CB $\quad$ CC

tubercle score by spermatogenic status

\begin{tabular}{|c|c|c|c|c|}
\hline pre & $0.00 \pm 0.00$ & $0.00 \pm 0.00$ (4) a & $0.75 \pm 0.45(12) a$ & $0.75 \pm 0.45$ (4) a \\
\hline early & $1.40 \pm 0.70(10) b$ & $1.11 \pm 0.60(9) b$ & $1.11 \pm 0.60$ (9) a & $1.26 \pm 0.56$ (19) a \\
\hline mid & $2.00 \pm 0.93$ (8) bc & $1.33+0.58(3) b$ & $2.00^{-} \quad$ (1) $a$ & nā \\
\hline $\begin{array}{l}\text { late } \\
\text { spent }\end{array}$ & $\underset{n a}{2.67 \pm 0.52 \quad(6) c}$ & $\begin{array}{c}1.44 \pm 0.73(9) b \\
n a\end{array}$ & $\begin{array}{ll}1.67 \pm 0.82 & \text { (6) } a \\
0.00 & \text { (1) } a\end{array}$ & $\begin{array}{c}2.00 \pm 0.63(6) b \\
n a\end{array}$ \\
\hline p-value & $<1.0 \mathrm{e}-4$ & 0.006 & 0.02 & 0.009 \\
\hline
\end{tabular}

tubercle score by visual condition

$\begin{array}{lccccc}\text { immature } & 0.00 \pm 0.00(4) \mathrm{a} & 0.00 \pm 0.00(3) \mathrm{a} & 0.00 \pm 0.00(2) \mathrm{a} & 0.50 \pm 0.71(2) \mathrm{a} \\ \text { inbetween } & 1.25 \pm 0.45(12) \mathrm{b} & 0.78 \pm 0.44(9) \mathrm{a} & 1.00 \pm 0.56(20) \mathrm{ab} & 1.00 \pm 0.00(4) \mathrm{a} \\ \text { mature } & 2.58 \pm 0.67(12) \mathrm{c} & 1.54 \pm 0.66(13) \mathrm{b} & 1.55 \pm 0.73(9) \mathrm{b} & 1.47 \pm 0.67(23) \mathrm{a} \\ \text { blackened } & \text { na } & \text { na } & \text { na } & & 1.00 \pm 0.00(2) \mathrm{a} \\ & & 0.0003 & 0.006 & \text { ns }\end{array}$

LI, Little Indian Creek; ICS, upper Clear Creek; CB, Conards Branch/Richland Creek; CC, lower Clear Creek; SD, standard deviation; (n), number of animals; na, none available in that category; ns, not significant 
Table 12. Male testes condition and gonadal somatic index (GSI) for Little Indian Creek (LI) across each month of the year.

\begin{tabular}{|c|c|c|c|c|c|c|c|c|c|c|}
\hline & $\mathrm{N}$ & $\begin{array}{c}\text { Monthly } \\
\text { mean } \\
\text { GSI }\end{array}$ & $\begin{array}{l}\text { Mature } \\
\text { GSI }\end{array}$ & $\begin{array}{c}\text { Mature } \\
\%\end{array}$ & $\begin{array}{c}\text { In- } \\
\text { Between } \\
\text { GSI }\end{array}$ & $\begin{array}{c}\text { In- } \\
\text { Between } \\
\%\end{array}$ & $\begin{array}{c}\text { Immature } \\
\text { GSI }\end{array}$ & $\begin{array}{c}\text { Immature } \\
\%\end{array}$ & $\begin{array}{l}\text { Blackened } \\
\text { GSI }\end{array}$ & $\begin{array}{c}\text { Blackened } \\
\%\end{array}$ \\
\hline January & 15 & 0.35 & & 0 & 0.94 & 26.7 & 0.13 & 73.3 & & 0 \\
\hline February & 5 & 0.53 & 1.72 & 20.0 & & 0 & 0.23 & 80.0 & & 0 \\
\hline March & 13 & 0.52 & 1.97 & 15.4 & 0.27 & 6.7 & 0.25 & 76.9 & & 0 \\
\hline April & 10 & 0.76 & 1.67 & 40.0 & 0.18 & 20.0 & 0.13 & 40.0 & & 0 \\
\hline May & 12 & 0.05 & & 0 & 0.09 & 8.3 & 0.05 & 91.7 & & 0 \\
\hline June & 7 & 0.07 & & 0 & 0.07 & 14.3 & 0.07 & 85.7 & & 0 \\
\hline July & 4 & 0.13 & & 0 & & 0 & 0.13 & 100 & & 0 \\
\hline August & 12 & 0.12 & & 0 & 0.25 & 8.0 & 0.11 & 91.7 & & 0 \\
\hline September & 1 & 0.04 & & 0 & & & 0.04 & 100.0 & & 0 \\
\hline October & 4 & 0.54 & 0.73 & 6.3 & 0.63 & 43.8 & 0.47 & 50.0 & & 0 \\
\hline November & 16 & 0.37 & 1.14 & 14.3 & 0.79 & 42.9 & 0.10 & 50.0 & & 0 \\
\hline December & 17 & 0.44 & 0.77 & 24.0 & 0.73 & 23.5 & 0.10 & 47.1 & & 0 \\
\hline
\end{tabular}


Table 13. Male testes condition and gonadal somatic index (GSI) for upper Clear Creek (ICS) across each month of the year.

\begin{tabular}{|c|c|c|c|c|c|c|c|c|c|c|}
\hline & $\mathrm{N}$ & $\begin{array}{c}\text { Monthly } \\
\text { mean } \\
\text { GSI }\end{array}$ & $\begin{array}{c}\text { Mature } \\
\text { GSI }\end{array}$ & $\begin{array}{c}\text { Mature } \\
\%\end{array}$ & $\begin{array}{c}\text { In- } \\
\text { Between } \\
\text { GSI }\end{array}$ & $\begin{array}{c}\text { In- } \\
\text { Between } \\
\%\end{array}$ & $\begin{array}{c}\text { Immature } \\
\text { GSI }\end{array}$ & $\begin{array}{c}\text { Immature } \\
\%\end{array}$ & $\begin{array}{l}\text { Blackened } \\
\text { GSI }\end{array}$ & $\begin{array}{c}\text { Blackened } \\
\%\end{array}$ \\
\hline January & 12 & 0.42 & 0.92 & 16.7 & 0.90 & 16.7 & 0.17 & 66.7 & & 0 \\
\hline February & 6 & 0.95 & 1.57 & 33.3 & 1.08 & 33.3 & 0.19 & 33.3 & & 0 \\
\hline March & 10 & 1.20 & 2.34 & 40.0 & 1.56 & 10.0 & 0.21 & 50.0 & & 0 \\
\hline April & 11 & 1.23 & 1.84 & 54.4 & 1.75 & 9.0 & 0.18 & 36.4 & & 0 \\
\hline May & 29 & 0.53 & 2.30 & 10.3 & & 0 & 0.31 & 89.7 & & 0 \\
\hline June & 13 & 0.27 & & 0 & & 0 & 0.27 & 100.0 & & 0 \\
\hline July & 13 & 0.30 & & 0 & 0.22 & 7.7 & 0.31 & 92.3 & & 0 \\
\hline August & 29 & 0.30 & & 0 & 0.29 & 31.0 & 0.31 & 69.0 & & 0 \\
\hline September & 3 & 0.28 & & 0 & & 0 & 0.28 & 100.0 & & 0 \\
\hline October & 12 & 0.56 & & 0 & 0.76 & 66.7 & 0.14 & 33.3 & & 0 \\
\hline November & 7 & 0.67 & 1.14 & 14.3 & 0.79 & 42.9 & 0.40 & 42.9 & & 0 \\
\hline December & 5 & 0.78 & & 0 & 1.15 & 40.0 & 0.54 & 60.0 & & 0 \\
\hline
\end{tabular}


Table 14. Male testes condition and gonadal somatic index (GSI) for Conards Branch (CB) across each month of the year.

\begin{tabular}{|c|c|c|c|c|c|c|c|c|c|c|}
\hline & $\mathrm{N}$ & $\begin{array}{c}\text { Monthly } \\
\text { mean } \\
\text { GSI }\end{array}$ & $\begin{array}{l}\text { Mature } \\
\text { GSI }\end{array}$ & $\begin{array}{c}\text { Mature } \\
\%\end{array}$ & $\begin{array}{c}\text { In- } \\
\text { Between } \\
\text { GSI }\end{array}$ & $\begin{array}{c}\text { In- } \\
\text { Between } \\
\%\end{array}$ & $\begin{array}{c}\text { Immature } \\
\text { GSI }\end{array}$ & $\begin{array}{c}\text { Immature } \\
\%\end{array}$ & $\begin{array}{l}\text { Blackened } \\
\text { GSI }\end{array}$ & $\begin{array}{c}\text { Blackened } \\
\%\end{array}$ \\
\hline January & 11 & 0.19 & & 0 & 0.80 & 9.1 & 0.13 & 90.9 & & 0 \\
\hline February & 8 & 0.12 & & 0 & & 0 & 0.12 & 100.0 & & 0 \\
\hline March & 11 & 0.20 & & 0 & & 0 & 0.20 & 100.0 & & 0 \\
\hline April & 2 & 1.87 & 1.87 & 100.0 & & 0 & & 0 & & 0 \\
\hline May & 6 & 0.85 & 1.45 & 50.0 & & 0 & 0.25 & 50.0 & & 0 \\
\hline June & 6 & 0.23 & & 0 & 0.29 & 66.7 & 0.10 & 33.3 & & 0 \\
\hline July & 9 & 0.17 & & 0 & & 0 & 0.17 & 100.0 & & 0 \\
\hline August & 11 & 0.21 & & 0 & 0.21 & 36.4 & 0.20 & 63.6 & 0.18 & 18.2 \\
\hline September & 15 & 0.24 & 0.38 & 26.7 & 0.30 & 33.3 & 0.10 & 40.0 & & 0 \\
\hline October & 14 & 0.28 & & 0 & 0.48 & 42.9 & 0.13 & 57.1 & & 0 \\
\hline November & 13 & 0.21 & & 0 & 0.55 & 21.4 & 0.11 & 71.4 & & 7.1 \\
\hline December & 9 & 0.27 & 0.72 & 11.0 & 0.67 & 22.2 & 0.07 & 66.7 & & 0 \\
\hline
\end{tabular}


Table 15. Male testes condition and gonadal somatic index (GSI) for lower Clear Creek (CC) across each month of the year.

\begin{tabular}{|c|c|c|c|c|c|c|c|c|c|c|}
\hline & $N$ & $\begin{array}{c}\text { Monthly } \\
\text { mean } \\
\text { GSI }\end{array}$ & $\begin{array}{l}\text { Mature } \\
\text { GSI }\end{array}$ & $\begin{array}{c}\text { Mature } \\
\%\end{array}$ & $\begin{array}{c}\text { In- } \\
\text { Between } \\
\text { GSI }\end{array}$ & $\begin{array}{c}\text { In- } \\
\text { Between } \\
\%\end{array}$ & $\begin{array}{c}\text { Immature } \\
\text { GSI }\end{array}$ & $\begin{array}{c}\text { Immature } \\
\%\end{array}$ & $\begin{array}{c}\text { Blackened } \\
\text { GSI }\end{array}$ & $\begin{array}{c}\text { Blackened } \\
\%\end{array}$ \\
\hline January & 12 & 0.51 & 1.08 & 25.0 & 1.02 & 16.7 & 0.12 & 58.3 & & 0 \\
\hline February & 13 & 0.28 & 1.21 & 15.4 & 0.14 & 23.1 & 0.10 & 61.5 & & 0 \\
\hline March & 13 & 1.20 & 2.43 & 46.2 & 1.56 & 10.0 & 0.15 & 53.8 & & 0 \\
\hline April & 15 & 0.98 & 2.02 & 40.0 & & 0 & 0.28 & 60.0 & & 0 \\
\hline May & 14 & 0.22 & & 0 & & 0 & 0.22 & 100.0 & & 0 \\
\hline June & 18 & 0.24 & & 0 & 0.21 & 11.1 & 0.24 & 88.9 & & 0 \\
\hline July & 12 & 0.25 & & 0 & 0.27 & 66.7 & 0.20 & 33.3 & & 0 \\
\hline August & 15 & 0.16 & & 0 & 0.21 & 13.3 & 0.12 & 60.0 & 0.22 & 26.7 \\
\hline September & 0 & & & & & & & & & \\
\hline October & 15 & 0.15 & & 0 & 0.22 & 6.7 & 0.14 & 93.3 & & 0 \\
\hline November & 14 & 0.40 & 1.15 & 14.3 & 0.79 & 14.3 & 0.18 & 71.4 & & 0 \\
\hline December & 11 & 0.67 & 1.24 & 45.5 & & 0 & 0.19 & 45.5 & & 0 \\
\hline
\end{tabular}


Table 16. Regression equations for male creek chub tubercle score versus testes gonadal somatic index (GSI)

\begin{tabular}{lcccc}
\hline Site & \multicolumn{3}{c}{ tubercle score } & $\mathrm{N}^{\mathrm{a}}$ \\
\hline all & $0.58 * \mathrm{GSI}+0.68$ & $\left(\mathrm{p}<0.0001 ; \mathrm{R}^{2}=0.25\right)$ & 115 \\
& & & \\
$\mathrm{LI}^{\mathrm{b}}$ & $1.21 * \mathrm{GSI}+0.49$ & $\left(\mathrm{p}<0.0001 ; \mathrm{R}^{2}=0.46\right)$ & $\mathrm{A}^{\mathrm{c}}$ & 29 \\
$\mathrm{ICS}^{\mathrm{d}}$ & $0.61 * \mathrm{GSI}+0.28$ & $\left(\mathrm{p}<0.002 ; \mathrm{R}^{2}=0.33\right)$ & $\mathrm{B}$ & 24 \\
$\mathrm{CB}^{\mathrm{e}}$ & $0.47 * \mathrm{GSI}+0.78$ & $\left(\mathrm{p}<0.038 ; \mathrm{R}^{2}=0.11\right)$ & $\mathrm{B}$ & 31 \\
$\mathrm{CC}^{f}$ & $0.56 * \mathrm{GSI}+0.56$ & $\left(\mathrm{p}<0.0001 ; \mathrm{R}^{2}=0.42\right)$ & $\mathrm{B}$ & 31 \\
\hline
\end{tabular}

${ }^{a}-\mathrm{N}$, number of fish included in regression.

b - LI, Little Indian Creek

c - Regression equations with different letters have significantly different slopes $(\alpha \leq 0.05)$

d- ICS, upper Clear Creek

e - CB, Conards Branch/Richland Creek

f - CC, lower Clear Creek 
Table 17. Mean male plasma vitellogenin $(V t g)$ and sex steroids estrogen $\left(E_{2}\right)$ and testosterone $(T)[\mathrm{ng} / \mathrm{ml} \pm \mathrm{SD}$, (N)] in creek chubs from seven PCB-contaminated streams: Clear Creek (ICS and CC), Conards Branch / Richland Creek (CB), Stouts Creek (SC), Sinking Creek (ABB) in Monroe County, Pleasant Run Creek (PR) in Lawrence County, the Little Mississenewa River (LM1 and LM2) in Randolph County, and Elliot Ditch / Wea Creek (ED2) in Tippecanoe County, Indiana. Also included are two uncontaminated reference sites: Little Indian Creek (LI), and Brummett Creek (BRUM), Greene and Monroe Counties and a slightly elevated background stream, Burnetts Creek (BC) in Tippecanoe County, Indiana. Means with different letters are significantly different $(\alpha \leq 0.05)$.

\begin{tabular}{|c|c|c|c|c|c|c|}
\hline Site & PCB level & $V \operatorname{tg}$ & $\mathrm{E}_{2}$ & $\mathrm{~T}$ & $\mathrm{E}_{2} / \mathrm{T}$ & $\mathrm{T} / \mathrm{E}_{2}$ \\
\hline$\overline{\mathrm{LI}}$ & reference & $0.017 \pm 0.02(2)$ & $0.01 \pm 0.00(2) \mathrm{AB}$ & $0.32 \pm 0.43(2)$ & $0.46 \pm 0.62(2) \mathrm{AB}$ & $21.3 \pm 28.5(2)$ \\
\hline Brum & reference & $0.00 \pm 0.00(6)$ & $0.08 \pm 0.05(6) \mathrm{A}$ & $0.43 \pm 0.63(6)$ & $5.30 \pm 5.70(7) \mathrm{A}$ & $21.6 \pm 51.4(7)$ \\
\hline $\mathrm{BC}$ & reference & $0.00 \pm 0.00$ & na & na & na & na \\
\hline LM1 & LowR & $0.06 \pm 0.13(7)$ & $0.01 \pm 0.00(6) B$ & na & na & na \\
\hline PR & LowR & $0.03 \pm 0.06(8)$ & $0.01 \pm 0.00(7) B$ & $0.61 \pm 0.82(7)$ & $0.57 \pm 0.53(7) B$ & $60.9 \pm 82.0(7)$ \\
\hline SC & LowR & $0.00 \pm 0.00(8)$ & $0.01 \pm 0.01(8) \mathrm{B}$ & $0.40 \pm 0.77(8)$ & $1.15 \pm 1.31(8) A B$ & $40.1 \pm 77.3(8)$ \\
\hline ABB & Medium & $0.003 \pm 0.007(8)$ & $0.03 \pm 0.04(5) A B$ & na & na & na \\
\hline CB & Medium & $0.009 \pm 0.016(7)$ & $0.02 \pm 0.01(7) \mathrm{B}$ & $0.23 \pm 0.54(6)$ & $1.32 \pm 0.97$ (4) $A B$ & $8.9 \pm 20.0$ \\
\hline $\mathrm{CC}$ & Medium & $0.025 \pm 0.03(5)$ & $0.03 \pm 0.04(5) A B$ & $0.14 \pm 0.26(5)$ & $0.73 \pm 0.38$ (5) $A B$ & $2.1 \pm 1.9(7)$ \\
\hline ED2 & High & $0.03 \pm 0.046(6)$ & 0.01 & na & na & na \\
\hline ICS & High & $0.007 \pm 0.009(7)$ & $0.02 \pm 0.03(7) \mathrm{B}$ & $0.33 \pm 0.85(7)$ & $2.04 \pm 3.22(7) \mathrm{AB}$ & $33.2 \pm 85.7(7)$ \\
\hline LM2 & High & $0.009 \pm 0.01(5)$ & $0.03 \pm 0.03(5) A B$ & na & na & na \\
\hline
\end{tabular}

PCB levels: Reference - reference site; lowR - site has been remediated resulting in significant PCB load reductions; medium - moderately contaminated; high - high contamination levels; $\mathrm{E}_{2}$ - estradiol; $\mathrm{T}$ - testosterone; na - not analyzed. 
Table 18. Mean female plasma vitellogenin $(\mathrm{Vtg})$ and sex steroids estrogen $\left(\mathrm{E}_{2}\right)$ and testosterone $(\mathrm{T})[\mathrm{ng} / \mathrm{ml} \pm \mathrm{SD},(\mathrm{N})]$ in creek chubs from seven PCB-contaminated streams: Clear Creek (ICS and CC), Conards Branch / Richland Creek (CB), Stouts Creek (SC), Sinking Creek (ABB) in Monroe County, Pleasant Run Creek (PR) in Lawrence County, the Little Mississenewa River (LM1 and LM2) in Randolph County, and Elliot Ditch / Wea Creek (ED2) in Tippecanoe County, Indiana. Also included are two uncontaminated reference sites: Little Indian Creek (LI), and Brummett Creek (BRUM), Greene and Monroe Counties and a slightly elevated background stream, Burnetts Creek (BC) in Tippecanoe County, Indiana. Means with different letters are significantly different $(\alpha \leq 0.05)$.

\begin{tabular}{|c|c|c|c|c|c|c|}
\hline Site & PCB level & $\mathrm{Vtg}$ & $E_{2}$ & $\mathrm{~T}$ & $\mathrm{E}_{2} / \mathrm{T}$ & $\mathrm{T} / \mathrm{E}_{2}$ \\
\hline$\overline{\mathrm{LI}}$ & reference & $92.3 \pm 25.0(6)$ & $0.49 \pm 0.41(4) A B$ & $0.12 \pm 0.13(4) \mathrm{A}$ & $5.2 \pm 2.7(4)$ & $0.22 \pm 0.08(4) A B$ \\
\hline Brum & reference & $93.9 \pm 10.8(3)$ & $1.08 \pm 0.28(3) B C$ & $0.07 \pm 0.05(3) \mathrm{A}$ & $36.0 \pm 43.5(3)$ & $0.07 \pm 0.06$ (3) A \\
\hline$B C$ & reference & $69.4 \pm 36.1(7)$ & $0.79 \pm 0.66(5) A C$ & na & na & na \\
\hline LM1 & LowR & $61.5 \pm 30.7(3)$ & $0.26 \pm 0.34(3) A B$ & na & na & na \\
\hline PR & LowR & $85.8 \pm 25.1(3)$ & $0.08 \pm 0.05$ (3) A & $0.14 \pm 0.04(3) A B$ & $0.5 \pm 0.2(3)$ & $2.43 \pm 1.52(3) A B$ \\
\hline SC & LowR & $89.7 \pm 29.6(2)$ & $0.56 \pm 0.09(2) A C$ & $1.35 \pm 0.92(2) B C$ & $0.5 \pm 0.3(2)$ & $2.30 \pm 1.27(2) A B$ \\
\hline ABB & Medium & $53.0 \pm 46.3(3)$ & $0.88 \pm 0.18(3) A C$ & na & na & na \\
\hline CB & Medium & $83.4 \pm 12.8(3)$ & $1.57 \pm 0.37(3) C$ & 0.01 & 301.3 & 0.003 \\
\hline CC & Medium & $40.2 \pm 42.7(6)$ & $0.29 \pm 0.12(5) A B$ & $0.44 \pm 0.49(5) A B$ & $9.2 \pm 13.6(5)$ & $1.30 \pm 1.29(5) A B$ \\
\hline ED2 & High & $76.3 \pm 66.3(3)$ & na & na & na & na \\
\hline ICS & High & 99.0 & $0.45 \pm 0.32(2) A B$ & $1.62 \pm 0.66(2) C$ & $0.26 \pm 0.09(2)$ & $4.10 \pm 1.42(2) B$ \\
\hline LM2 & High & $60.2 \pm 26.2(5)$ & $0.28 \pm 0.17(5) A B$ & na & na & na \\
\hline
\end{tabular}

PCB levels: Reference - reference site; lowR - site has been remediated resulting in significant PCB load reductions; medium - moderately contaminated; high - high contamination levels. $\mathrm{E}_{2}$ - estradiol; $\mathrm{T}$ - testosterone; na - not analyzed. 
Table 19. Relevant regression equations for female creek chub reproduction parameters from the 2009 sampling effort.

\begin{tabular}{|c|c|c|}
\hline regression & significance & $N^{a}$ \\
\hline $\mathrm{GSI}^{\mathrm{b}}=0.10 * \mathrm{Vtg}^{\mathrm{c}}+6.85$ & $\left(p<0.043 ; R^{2}=0.19\right)$ & 18 \\
\hline$E_{2}{ }^{d}=-0.15 * P C B s^{e}+0.65$ & $\left(p<0.011 ; R^{2}=0.28\right)$ & 19 \\
\hline \multicolumn{3}{|c|}{$\begin{array}{l}\text { a }-N \text {, number of fish included in regression. } \\
\text { b- GSI, gondal (ovary) somatic index } \\
c-V t g \text {, plasma vitellogenin }(\mathrm{ng} / \mathrm{ml}) \\
\text { d }-E_{2} \text {, plasma estradiol }(\mathrm{ng} / \mathrm{ml}) \\
\text { e }- \text { PCBs, mean whole body creek chub PCB concentration }(\mu \mathrm{g} / \mathrm{g})\end{array}$} \\
\hline
\end{tabular}


Table 20. Fish sex steroid ratios [estrogen $\left(E_{2}\right)$ and testosterone $(T)$ ] taken from the reference site(s) or experimental controls of several literature studies. Ratios presented in ( ) were calculated from data presented in the various studies.

\begin{tabular}{|c|c|c|c|c|c|}
\hline Author & $\begin{array}{l}\text { Species } \\
\text { Studied }\end{array}$ & $\begin{array}{r}\text { female } \\
E_{2} / T\end{array}$ & $\begin{array}{l}\text { female } \\
T / E_{2}\end{array}$ & $\begin{array}{l}\text { male } \\
\mathrm{E}_{2} / \mathrm{T}\end{array}$ & $\begin{array}{l}\text { male } \\
\mathrm{T} / \mathrm{E}_{2}\end{array}$ \\
\hline$\overline{\text { Armstrong et al. (2016) }}{ }^{a}$ & fathead minnow & $(\sim 2.0)$ & $(\sim 0.50)$ & $(<0.20)$ & $(\sim 6.0)$ \\
\hline Ankley et al. $(2001)^{a}$ & fathead minnow & $(\sim 2.5)$ & $(\sim 0.4)$ & $(\sim 0.2)$ & $(\sim 5.0)$ \\
\hline Ankley et al. (2003) ${ }^{a}$ & fathead minnow & $(\sim 1.0)$ & & $(\sim 0.03)$ & $(\sim 40.0)$ \\
\hline Ankley et al. (2008) ${ }^{a}$ & fathead minnow & $(\sim 1.2)$ & $(\sim 0.8)$ & & \\
\hline Baldigo et al. (2006) & $\begin{array}{l}\text { common carp } \\
\text { largemouth bass } \\
\text { smallmouth bass }\end{array}$ & $\begin{array}{l}0.57 \\
0.63 \\
0.36\end{array}$ & $\begin{array}{l}(\sim 2.0) \\
(\sim 1.6) \\
(\sim 2.8)\end{array}$ & $\begin{array}{l}0.1 \\
1.06 \\
0.16\end{array}$ & $\begin{array}{l}(\sim 9.0) \\
(\sim 0.94) \\
(\sim 6.3)\end{array}$ \\
\hline Folmar et al. (1996) ${ }^{\mathrm{C}}$ & common carp & nd & nd & $(0.02)$ & $(64.0)$ \\
\hline Giesy et al. (2003) ${ }^{a}$ & goldfish & $\sim 0.8$ & $(\sim 1.23)$ & $\sim 0.14$ & $(\sim 1.2)$ \\
\hline Jensen et al. (2001) ${ }^{a}$ & fathead minnow & $(-2.5)$ & $(\sim 0.4)$ & $(\sim 0.04)$ & $(\sim 25.0)$ \\
\hline Jensen et al. (2006) ${ }^{a}$ & fathead minnow & $(\sim 0.6)$ & $(\sim 1.7)$ & $(\sim 0.04)$ & $(\sim 27.0)$ \\
\hline Nichols et al. (1999) ${ }^{a}$ & fathead minnow & $>2.0$ & $(<0.5)$ & $0.8-0.9$ & $(1.1-1.2)$ \\
\hline Lui et al. (2009) ${ }^{a}$ & zebrafish & $(\sim 1.2)$ & $\sim 0.8$ & $(\sim 0.5)$ & $\sim 2.0$ \\
\hline Sepulveda et al. (2003) ${ }^{b}$ & largemouth bass & $2.0-4.0$ & $(0.25-0.5)$ & $0.4-0.5$ & $(2.0-2.5)$ \\
\hline Shang et al. (2006) ${ }^{a}$ & zebrafish & $(\sim 4.5)$ & $0.22 \pm 0.04$ & $(\sim 0.83)$ & $1.2 \pm 0.28$ \\
\hline
\end{tabular}


CHAPTER 4 -- Can age structure alterations and growth impairment of creek chub (Semotilus atromaculatus) in PCB-contaminated streams constitute a Natural Resource Injury?

\section{Abstract}

We examined creek chubs from two PCB contaminated streams (Clear Creek and Richland Creek) at three locations and a reference stream (Little Indian Creek) to determine if age class structure and growth parameters were correlated with in-situ PCB exposure. Exposure to PCBs has been shown to both enhance and decrease growth in varied laboratory tests; we observed subtle but significant sex-specific differences in the growth of creek chub populations between our sites. Female creek chubs up to 24 months in age from Clear Creek and Richland Creek were significantly larger in both length and weight than females from the reference site. This trend was reversed for creek chubs older than 24 months as the reference site fish were larger in both length and weight than fish from PCB-contaminated streams. Older age classes of creek chubs were missing at the site of highest PCB contamination. Female population growth rates and individual instantaneous growth rates were consistently higher at the reference site in comparison to the PCB-contaminated sites. Furthermore, dimorphic growth differences were much less pronounced between males and females within each PCB-contaminated streams in comparison to reference conditions. Adverse impacts to growth have been demonstrated sufficient to meet the acceptance criteria for determining injury to biological resources in the Natural Resource Damage Assessment regulations found at (43 CFR $11.62(f)(2))$. 


\section{Introduction}

Fish growth has long been studied as it is a complex matter interrelated with mortality, reproductive capacity and survivorship. Black et al. (1998a; 1998b) not only documented reproductive effects in mummichugs (Fundulus heteroclitus) (Linneaus) from the PCB-contaminated New Bedford Harbor Superfund site (MA, USA), but also documented reduced survivorship in older females which correlated with total PCB concentrations. Decreased survivorship has been an indicator of toxicity since the inception of toxicity testing (Rand and Petrocelli 1985). Growth has been used as a predictive indicator of health in almost all aquatic toxicity testing scenarios, most notability with amphipods and other invertebrates (ASTM 2004a, 2004b; U.S. EPA 2000). The development of water quality criteria for polychlorinated biphenyls (PCBs) included consideration of growth effects on fish during laboratory toxicity testing (Hansen et al. 1973, 1974; Nebeker and Puglisi 1974; Nebeker et al. 1974; Schimmel et al. 1974; DeFoe et al. 1978).

Experimental exposures of fish to PCBs have documented both growth enhancement and growth reduction (Nebeker et al. 1974; Hansen et al. 1976; DeFoe et al.1978; Mauck et al. 1978; Bengtsson 1980; Mac and Seelye 1981a, 1981b). Hashmi et al. (2015) considered the stimulatory effect (hormesis) of low doses of PCB 31 to be beneficial because it increased growth at day 14 and 21 in zebrafish (Danio rerio). Stimulated growth was not considered a benefit but an adverse effect because later it was associated with decreased longevity (Bengtsson 1979). Reduced growth has been identified as "wasting away," a precursor to death (Halter and Johnson 1974; Bengtsson 
1980; Cleland et al. 1988). Field studies have shown that living in estuaries with low levels of PCBs and other pollutants in sediment leads to decreased growth and longevity (McGourty et al. 2009; Evrad et al. 2010). Young-of-year bluefish fed prey collected from PCB- and Hg-contaminated Hackensack River estuary displayed significantly reduced growth that was a detriment to survival (Candelmo et al. 2010).

Others have argued that PCB contamination does not negatively impact fish growth rates (Rypel and Bayne 2010). Many factors influence growth variations in fish at large spatial scales including life history, physiology, sex, habitat type (physio-chemical properties of habitat including water temperature), prey availability, and ecosystem structure and function (Ricker 1979). Given that the biological processes for fish growth can be complicated to investigate, should attempts even be made? Can the many factors be controlled in a manner that isolates one factor to establish cause and effect beyond a reasonable doubt? Or attain statistical significance? Perhaps meet the standard of more likely than not? In a laboratory or microcosm setting, many of these factors can be controlled but there are also circumstances in which chronic adverse impacts are not readily observed in a short-term experiment. It is important to corroborate results from laboratory studies with observations made in the environment.

As part of the U.S. Department of the Interior's Natural Resource Damage Assessment Injury Determination process, corroborating laboratory test results with field studies is required (43 CFR 11.62 (f) (2)). The method for determining injury is to be chosen based on the capability of the method to demonstrate a measurable biological response. The four acceptance criteria for confirming injury to biological resources are: 1) the biological response is often the result of exposure to the hazardous substance in 
question, 2) the effect has been documented in free-ranging organisms, 3) the effect has been documented in controlled experiments, and 4) the biological response measurement is practical to perform producing scientifically valid results.

The objectives of our research are to evaluate age class structure and growth endpoints in relation to the NRDA acceptance criteria to determine if fish growth and age class structure are sensitive indicators of adverse impacts relative to ambient PCB concentrations. Additionally, we make management recommendations on how to thoroughly evaluate such data and suggest pitfalls to avoid.

\section{Materials and Methods}

Site Description

Lemon Lane Landfill (LL) and Neal's Landfill (NL) are National Priorities List (Superfund) sites located in Monroe County, Indiana, USA. We collected creek chubs from Clear Creek at 2 locations (ICS and CC) downstream of the primary discharge of PCBcontaminated groundwater emanating from LL. The ICS site (drainage area $6.0 \mathrm{~km}^{2}$ ) was located 1,400 m downstream and the CC site (drainage area $16.3 \mathrm{~km}^{2}$ ) was located 3,100 $\mathrm{m}$ downstream of the LL discharge springs. We also sampled Conards Branch / Richland Creek (CB) (drainage area $8.0 \mathrm{~km}^{2}$ ) approximately $800 \mathrm{~m}$ downstream of the primary discharge of PCB-contaminated groundwater emanating from NL. The reference site for our study was on Little Indian Creek (LI) just upstream of its confluence with Indian Creek (drainage area $17.4 \mathrm{~km}^{2}$ ). All 4 sites are in the White River drainage, Monroe County, Indiana (Fig. 1). Table 1 provides qualitative habitat characteristics for these sites. Over 
the course of many years, hundreds of samples have been collected from these study sites and chemically analyzed for hazardous substances, including PCBs. Sample types included: groundwater at the source spring, ambient surface water at various downstream locations, sediment and whole creek chubs (Table 2). It is clear from the many rounds of Superfund directed priority pollutant analytical chemistry analyses that PCBs are the only significant bioaccumulating contaminant of concern at ICS, CC and CB study sites (ISDH 1994). Only very low concentrations of PCBs are found in fish at $\mathrm{LI}$, confirming that this site is suitable to represent background conditions for southwestern Indiana.

\section{Field Collection}

Creek chubs were collected from all sites, usually within 24 hours, during daylight hours using a battery back-pack pulsed-DC electrofishing unit (model ABP-3-450V, ETS Electrofishing LLC, Verona, WI) capable of 2-3 Amp output. Monthly collections occurred during April 1999 to March 2000, October to December 2001 and October 2004 to February 2005. At the end of each sampling event, approximately $10-20$ creek chubs were preserved in $10 \%$ formalin and taken to the laboratory for processing.

\section{Age and Growth Methodology}

Preserved creek chubs were rinsed in tap water, blotted dry, and mass (BW) measured to the nearest $0.1 \mathrm{~g}$. Total length (TL) was measured to the nearest $0.1 \mathrm{~mm}$ from the anterior most part of the fish to the longest caudal fin ray length by depressing the caudal lobe dorso-ventrally (Anderson et al. 1989). Several scales were obtained above the lateral line, anterior to the base of the dorsal fin for aging by counting annuli (Jearld 1989) 
using a Leica MZ12.5 stereomicroscope equipped with a Leica DFC290 digital camera (Leica, Heerbrugg, Switzerland) and transmitted light using dark field lighting. A subset of fish had otoliths removed and analyzed for comparison purposes $(n=73,90 \%$ age agreement with scales, Table 2). Taking into account that scale annuli are formed in the coldest months of the year and creek chubs typically spawn and hatch in late March and early April in the Midwest (D. Sparks, pers. obs.), we assigned age two ways, age in months and age in years. We photographed several scales from each fish using Leica Application Suite software (version 4.8.0) and we measured scale length and annuli using Leica's Manual Measurements module via the Dahl-Lea method (a direct proportion basis) to back calculate lengths-at-age (Lagler 1956). We determined the age of 1,094 fish from all sites, including age 0 fish. A total of 907 creek chubs were age 1 or greater and were included in the back-calculation of size at successive annuli (Ricker 1975). Ordinary and Functional b (condition factor) regressions were calculated (Ricker 1975) according to the following formulae:

$$
\begin{aligned}
& W=a L^{b} \\
& \log W=\log a+b(\log L)
\end{aligned}
$$

where $W=$ total weight $(\mathrm{g}), a=$ the intercept, and $L=$ total length (mm). Ricker (1975) states that "usually the best available estimate of the growth rate of individual fish (G) comes from the back-calculation of their length at the last two annuli on the scales." Individual instantaneous growth rate of length increase was calculated for each age class interval available at our study sites (Ricker 1975) according to the following formula:

$$
G=b\left(\log _{e} L_{2}-\log _{e} L_{1}\right)
$$

where $G=$ individual instantaneous growth rate of length increase, $b=$ is the calculated 
functional $\mathrm{b}$ for that age class, $L_{1}=$ the back-calculated total length of the fish at the second to last annuli, and $L_{2}=$ the back calculated total length of the fish at its last annuli. Population instantaneous growth rate of length increase $\left(G_{x}\right)$ was obtained by comparing the mean size of surviving fish at successive ages in the same manner (Ricker, 1975). All calculations were conducted separately for males and females because creek chubs are sexually dimorphic. For discussion purposes, actual survivorship is defined by successful capture of successive ages of whereas the lack of capture is evidence of lack of survivorship.

\section{Statistics}

All statistical analyses on total length $(T L)$ and body weight (BW) were performed using $R$ (R Core Team 2013) for ANOVA (across sites), t-tests (across sex within sites) and regressions (for each sex within sites). Total length and BW were correlated to age in years and age in months, by assuming April 1 of each year was the estimated hatching date of all creek chubs. Statistical significance was set at $\alpha<0.05$.

\section{Results}

At the reference site, males were significantly longer and weighed significantly more than females in years beyond 12 months (Table 3). This sexual dimorphism was much less distinct at the PCB-contaminated sites (Table 3). The slopes of the length versus age and weight versus age equations for both males and females decreased significantly at the PCB-contaminated sites relative to the reference site (Table 4). No males $>4$ years old, 
and no females $>3$ years old were captured at ICS, the most contaminated site (Tables 5 and 6). For females, both length and weight was significantly increased at the PCB sites for creek chubs less than 24 months in age (length, $p<0.001-0.018$; weight, $p<0.001$ - 0.004). Reference site males less than 13 months in age were significantly smaller $(p<$ $0.01-0.03)$ than PCB-site males. At age 3 and older, male creek chubs from the reference site (LI) grew longer and weighed more than fish from the PCB-contaminated sites (Fig. 2). Reference females aged 24 months and greater were larger than females from the PCB-contaminated sites (Fig. 2). Captured reference site creek chubs was more evenly distributed across relative length than from the PCB-contaminated streams. Fish less than $30 \mathrm{~mm}$ in size (representing early age $0 \mathrm{fish}$ ) were not frequently captured at ICS and CC (Fig. 3). Fig. 3 also indicates the reduced numbers of larger fish at the highest PCB-contaminated site.

Mean calculated total length at successive annuli are presented in Tables 5 and 6. From these data, we calculated instantaneous growth rates for all age classes at all sites. In almost all cases, both population and mean individual instantaneous growth rates were higher in all of the age classes of reference site (LI) female fish (Table 7). Reference male population instantaneous growth rate for year 1 to 2 is higher than that of the PCBcontaminated sites. The population instantaneous growth rate for year 2 to 3 was elevated at the PCB sites compared to $\mathrm{LI}$, but reference instantaneous growth rates were higher in later years. On the basis of the functional b metric, reference site males (Table 8) and females (Table 9) exhibited an increased weight relative to length when compared to fish from the PCB-contaminated sites. 


\section{Discussion}

The purpose of this study was to critically evaluate the observable effects of PCB exposure on the growth and survivorship of creek chub in a field setting in relation to the "acceptance criteria" [43 C.F.R. 11.62 (f)(2)] for determining if there was an adverse change sufficient to constitute an injury to biological resources. The growth rates of male and female creek chubs from the reference site have significantly larger slopes of the regressions (Table 4). This indicates that growth has been significantly reduced at the PCB-contaminated sites. It is also clear that females are more adversely impacted at the PCB-contaminated sites than males in terms of growth reductions and actual survivorship. General parameters of growth, including population and individual instantaneous growth rates ( $G_{x}$ and $G$, respectively) correlate inversely with PCBs for females (less so for males). The mixed results of the calculated functional $b$ metric did not provide additional information on site specific growth differences at these sites. Generally, a functional regression value of $b$ equal to 3.0 indicates isometric growth. Higher values of b indicate better "condition" or a more rotund fish (Ricker 1975; Anderson and Gutreuter 1989). Lower values of $b$ would indicate less weight being added by the fish as length increased. In extreme cases, low b values would indicate emaciation type effects. In both males and females, there is evidence of this in older age classes of fish from the PCBcontaminated sites based on declining functional $\mathrm{b}$ metrics.

The results of our study are consistent with the finding of many of the studies that were used in the development of water quality criteria for PCBs (Hansen et al. 1973, 1974; Nebeker and Puglisi 1974; Nebeker et al. 1974; Schimmel et al. 1974; Hansen et 
al. 1975; DeFoe et al. 1978). Our results are similar to other studies which have shown both growth enhancement and growth reduction resulting from PCB exposures (Nebeker et al. 1974; Halter and Johnson 1974; Hansen et al. 1976; DeFoe et al. 1978; Mauck et al. 1978; Bengtsson 1979, 1980; Mac and Seelye 1981a, 1981b; Cleland et al. 1988). Wild caught female Fundulus heteroclitus (Linnaeus) from two sites in the PCBcontaminated New Bedford Harbor, MA had significantly greater mortality (23-30\%) versus the reference site $(0 \%)$ when brought into the laboratory to investigate reproductive success (Black et al. 1998a). Growth was also reduced for the female fish from the PCB-contaminated sites over the course of the 5 week study (Black et al. 1998b).

Another recent PCB fish growth injury investigation came to conclusions much different than ours. In the Logan Martin Reservoir, AL site, Rypel and Bayne (2010) stated that growth was positively correlated with PCB concentration because older fish contained higher PCB concentrations. It was inferred that PCBs may even be beneficial to fish growth (Rypel and Bayne 2010) although it-has been well established that larger fish of the same species will invariably retain larger amounts of bioaccumulating substances. Larger sample sizes, more detailed comparisons to reference conditions and an data on fish community structure could have been much more illuminating.

Although creek chubs are sexually dimorphic, it is clear from this current study that PCB contamination impacts the growth of males and females differently (Table 3). In ideal conditions, male creek chubs continue to grow in length and weight as they age, although the rate of weight gain outpaces gains in length as fish age. Although female creek chubs continue to gain weight as they age, gains in length are not as pronounced as it is in 
males. This is likely due to the physiological energy demands of egg production. The growth differential between males and females is clear at LI, but less so at the PCBcontaminated sites. This might indicate that the normal reproductive process (e.g. energy demand) is somewhat altered at the PCB sites. And consistent with what was previously observed, PCB contamination results in missing larger female fish (Henshel et al. 2006).

The creek chub makes an excellent field study species since it is relatively abundant and present in many PCB contaminated streams. This present study has demonstrated significant differences in creek chub growth between the PCBcontaminated sites and nearby reference conditions. Poor growth and altered survival in female creek chubs is an adverse impact to the aquatic ecosystem. It is directly linked to less reproduction (Quinn and Deriso 1999) and fewer fish. The ramifications of lowered female survivorship can also be found in the entire fish community on close examination (Simon et al. 2013; Chapter 5). Although not every indicator of growth evaluated in this study confirmed that growth was impaired in every instance, the weight of the evidence confirms injury is more likely than not to have occurred at the PCB-contaminated sites pursuant to the acceptance criteria at 43 CFR 11(f)(2). The "more likely than not" standard of proof is what would be required to succeed in civil litigation in a US district court.

Conducting a comprehensive age and growth study of this magnitude (more than 1,100 fish from 4 sites) is a monumental undertaking with practical limitations. This worked well in small streams with a common minnow species. It would be more difficult to obtain state permits to conduct such a study on highly desirable game fish species, and increased effort to collect assuming one could cover the length of river involved to capture 
this many individuals. And this would complicate the effort to understand PCB exposure assessment given a much larger study area. A study of desirable game fish species might be considered more meaningful in court, but a 1,000 fish study of desirable game fish would be criticized as more destructive than the problem PCBs have caused (whether true or not) due to its visibility. Water treatment for PCBs substantially increased starting in 2000 at these contaminated study sites, and with our samples being collected from 1999 to early 2005, it was likely that conditions were improving throughout the study period. A more targeted sampling effort before remedial efforts were underway might have strengthened our arguments.

\section{References}

Anderson RO, Gutreuter SJ (1989) Length, weight, and associated structural indices. In: Nielson LA, Johnson DL (eds) Fisheries techniques, Southern Printing Company, Inc. Blacksburg, VA, pp 283-300

American Society for Testing and Materials (ASTM) (2004a) Standard test method for measuring the toxicity of sediment-associated contaminants with freshwater invertebrates. E 1706-00. In: Annual Book of ASTM Standards, Vol 11.05. Philadelphia, PA. pp 1148-1265

ASTM (2004b) Standard guide for determination of the bioaccumulation of sedimentassociated contaminants by benthic invertebrates. E 1688-00a. In: Annual Book of ASTM 
Standards, Vol 11.05. Philadelphia, PA. pp 1077-1131

Bengtsson BE (1979) Increased growth in minnows exposed to PCBs. Ambio 8:169-170

Bengtsson BE (1980) Long term effects of PCB (Clophen A50) on growth, reproduction and swimming performance in the minnow Phoxinus phoxinus. Water Res 14:681-687

Black DE, Gutjahr-Gobell R, Pruell RJ, Bergen B, Mills L, McElroy AE (1998a) Effects of a mixture of non-ortho- and mono-ortho-polychlorinated biphenyls on reproduction in Fundulus heteroclitus (Linnaeus). Environ Toxicol Chem 17:1396-1404

Black DE, Gutjahr-Gobell R, Pruell RJ, Bergen B, Mills L, McElroy AE (1998b) Reproduction and polychlorinated biphenyls in Fundulus heteroclitus (Linnaeus) from New Bedford Harbor, Massachusetts, USA. Environ Toxicol Chem 17:1405-1414

Candelmo AC, Deshpande A, Dockum B, Weis P, Weis J (2010) The effect of contaminated prey on feeding, activity, and growth of young of the year bluefish, Potatomus saltatrix, in the laboratory. Estuaries and Coasts 33:1025-1038

CBS (1998) Letter regarding preliminary data for sampling performed under Bloomington Project Quality Assurance Project Plan Volume IX, Neal's Landfill stream sampling plan. From Dorothy M. Alke, Project Director, to Distribution List. June 29, 1998 
Cleland GB, McElroy PJ, Sonstegard RA (1988) The effect of dietary exposure to Arochlor 1254 and/or mirex on humoral immune expression of rainbow trout (Salmo gairdneri). Aquatic Toxicol 12:141-146

DeFoe DL, Veith GD, Carlson RW (1978) Effects of Arochlor 1248 and 1260 on the fathead minnow (Pimephales promelas). J Fish Res Board Can 35:997-1002

Evrad E, Devaux A, Bony S, Burgeot T, Riso R, Budzinski H, Le Du M, Quiniou L, Laroche J (2010) Responses of the European flounder Paltichthys flesus to the chemical stress in estuaries: load of contaminants, gene expression, cellular impact and growth rate. Biomarkers 15:111-127

Halter MT, Johnson HE (1974) Acute toxicities of a polychlorinated biphenyl (PCB) and DDT alone and in combination to early lifestages of coho salmon (Orcorhynchus kisutch). J Fish Res Board Can 31:1543-1547

Hansen DJ, Schimmel SC, Forester J (1973) Aroclor 1254 in eggs of sheepshead minnows: effects on fertilization success and survival of embryos and fry. Proc $27^{\text {th }}$ Annual Conf Southeastern Assoc Game Fish Commission pp 420-826

Hansen DJ, Parrish PR, Forester J (1974) Arochlor 1016: toxicity to and uptake by estuarine animals. Environ Res 7:363-373 
Hansen DJ, Schimmel SC, Forester J (1975) Effects of Arochlor 1016 on embryos, fry, juveniles and adults of sheepshead minnows (Cyprinodon variegatus). Trans Am Fish Soc 3: $584-588$

Hansen GL, Wiekhorst WB, Simon J (1976) Effects of dietary Aroclor 1242 on channel catfish (Ictalurus punctatus) and the selective accumulation of PCB components. J Fish Res Board Can 33:1343-1352

Hashmi MZ, Naveedullah, Shen CF, Yu CN (2015) Hormetic responses of food-supplied PCB 31 to zebrafish (Danio rerio) growth. Dose Response 13(1): doi:10.2203/doseresponse.14-013.Chaofeng

Henshel DS, Sparks DW, Simon TP, Tosick MJ (2006) Age structure and growth of Semotilus atromaculatus (Mitchill) in PCB-contaminated streams. J Fish Biol 68:44-62

Indiana State Department of Health (ISDH) (1994) Preliminary data evaluation and pathway analysis report for consent decree PCB sites. Indianapolis, IN. pp 361

Jearld A (1989) Age determination. In: Nielson LA, Johnson DL (eds) Fisheries techniques. Southern Printing Company, Inc. Blacksburg, VA. pp 301-324

Lagler KF (1956) Freshwater Fishery Biology, $2^{\text {nd }}$ edn. Brown Publishers, Dubuque, IA 
Mac MJ, Seelye JG (1981a) Potential influence of acetone in aquatic bioassays testing the dynamics and effects of PCBs. Bull Environ Contam Toxicol 27:359-367

Mac MJ, Seelye JG (1981b) Patterns of PCB accumulation by fry of lake trout. Bull Environ Contam Toxicol 27:368-375

Mauck WL, Mehrle PM, Mayer FL (1978) Effects of the polychlorinated biphenyl Arochlor 1254 on growth, survival, and bone development in brook trout (Salvenlinus fontinalis). J Fish Res Board Can 35:1084-1088

McGourty CR, Hobbs JA, Bennett WA, Green PG, Hwang HM, Ikemiyagi N, Lewis L, Cope JM (2009) Likely population-level effects of contaminants on a resident estuarine fish species: comparing Gillichthys mirabilis population static measurements and vital rates in San Francisco and Tomales Bays. Estuaries and Coasts 32:1111-1120

Moshenko RW, Gee JH (1973) Diet, time and place of spawning, and environments occupied by creek chub (Semotilus atromaculatus) in the Mink River, Manitoba. J Fish Res Board Can 30:357-362

Nebeker AV, Puglisi FA (1974) Effect of polychlorinated biphenyls (PCBs) on survival and reproduction of Daphnia, Gammarus, and Tanytarus. Trans Am Fish Soc 103:722-728

Nebeker AV, Puglisi FA, DeFoe DL (1974) Effect of polychlorinated biphenyl compounds 
on survival and reproduction of the fathead minnow and flagfish. Trans Am Fish Soc 103:562-568

Normandeau Associates (1995) Ecological Assessment of Illinois Central/Quarry Springs System and Clear Creek 1994. 141 pp. Spring City, PA.

Quinn II TJ, Deriso RB (1999) Quantitative Fish Dynamics. Oxford University Press, New York

R Core Team (2013) R: a language and environment for statistical computing. R Foundation for Statistical Computing, Vienna, Austria. http://www.R-project.org/. Accessed 7 July 2014

Rand GM, Petrocelli SR (1985) Fundamentals of Aquatic Toxicology: methods and applications. Hemisphere Publishing Corporation, Washington

Ricker WE (1975) Computation and interpretation of biological statistics of fish populations. Bull Fish Res Board Can 191:1-382

Ricker WE (1979) Growth rates and models. In: Hoar WS, Randall DJ, Brett JR (eds) Fish physiology Volume VIII Bioenergetics and growth. Academic Press, New York pp 677743 
Rypel AL, Bayne DR (2010) Do fish growth rates correlate with PCB body burden? Environ Pollut 158:2533-2536

Simon TP, Morris CC, Sparks DW (2013) Patterns in stream fish assemblage structure and function associated with a PCB gradient. Arch Environ Contam Toxicol 65:286-299

Schimmel SC, Hansen DJ, Forester J (1974) Effects of Aroclor 1254 on laboratory-reared embryos and fry of sheepshead minnows (Cyprinodon variegatus). Trans Am Fish Soc $103: 582-586$

Tetra Tech EM, Inc. (2000) Revised current status report for groundwater, surface water, sediment and fish data: Neal's Landfill Site, Monroe County, Indiana. 606 pp, Chicago, IL.

Tetra Tech EM, Inc. (2001) Draft current status report for groundwater, surface water, soil, sediment and fish data: Lemon Lane Landfill Site, Monroe County, Indiana. 189 pp, Chicago, IL

U.S. Environmental Protection Agency (U.S. EPA) (1992) Ecological assessment report for ICS/Quarry Springs Complex, Lemon Lane Landfill, Bloomington, Indiana. 21 pp Office of Superfund, Chicago, IL

U.S. EPA (2000) Methods for measuring the toxicity and bioaccumulation of sedimentassociated contaminants with freshwater invertebrates, $2^{\text {nd }}$ edn. EPA 600/R-99/064. 
Washington, DC

Westinghouse Electric Corporation (1997) Final data transmittal for ecological / human health risk assessment samples taken in November 1996, under the October 1996 field sampling plan to the ecological risk assessment of the Lemon Lane Landfill - IC/QS site. From Dorothy M. Alke, Project Director, to Distribution List. May 19, 1997. 211 pp 
Fig. 1. Location of the study sites in the White River drainage, including: upper and lower Clear Creek (ICS and CC), Conards Branch / Richland Creek (CB) and reference site Little Indian Creek (LI), Indiana. 


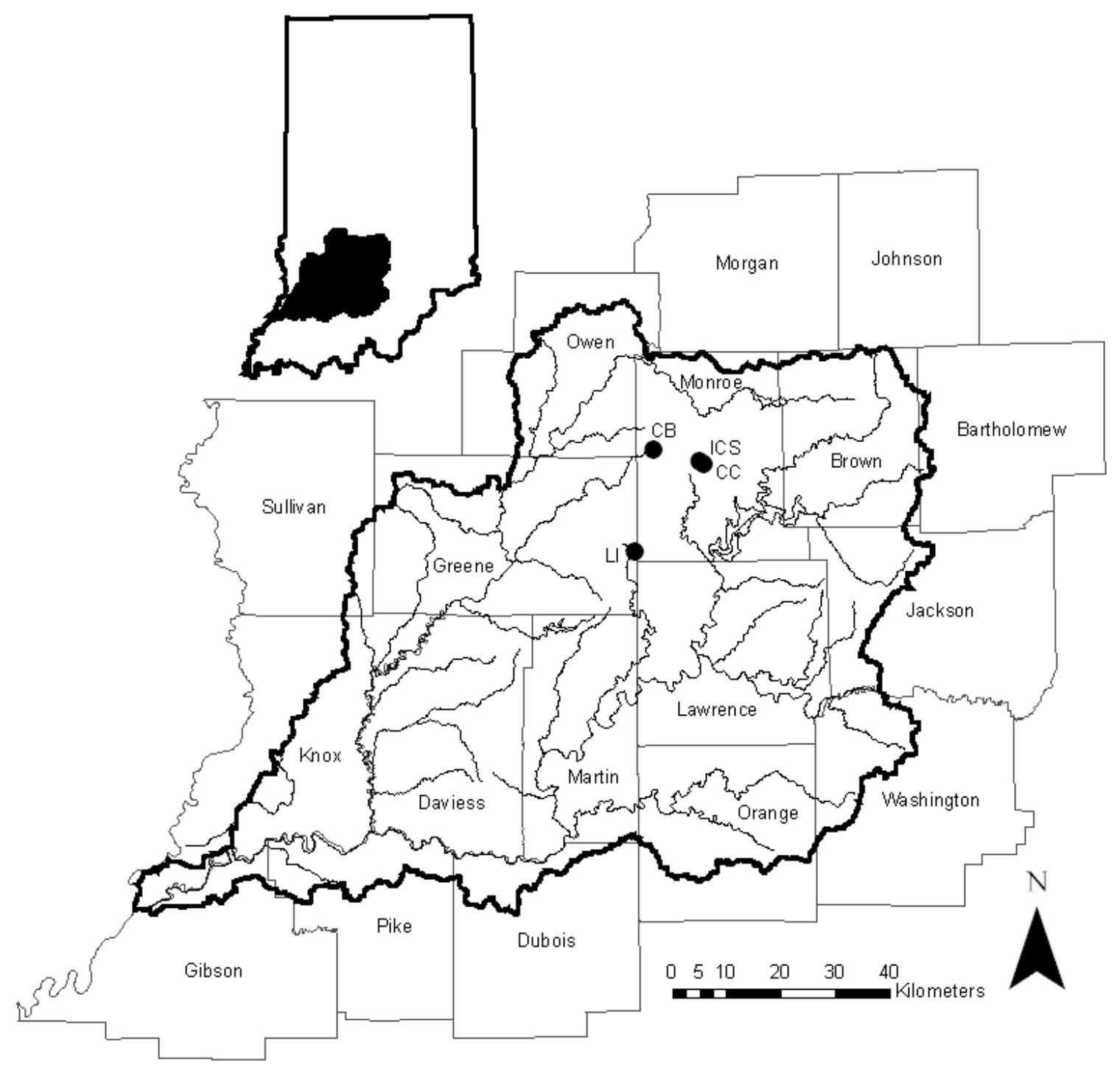


Fig. 2. Creek chub: a) mean male mass (g), b) mean female mass (g), c) male total length $(T L)(m m)$ and d) female total length $(T L)(\mathrm{mm})$ at Little Indian Creek (LI), upper Clear Creek (ICS), Conards Branch and Richland Creek (CB) and lower Clear Creek (CC). Error bars represent 1 SD above the mean. Asterisks denote significant differences from reference site (LI) at $\alpha<0.05$. 
a

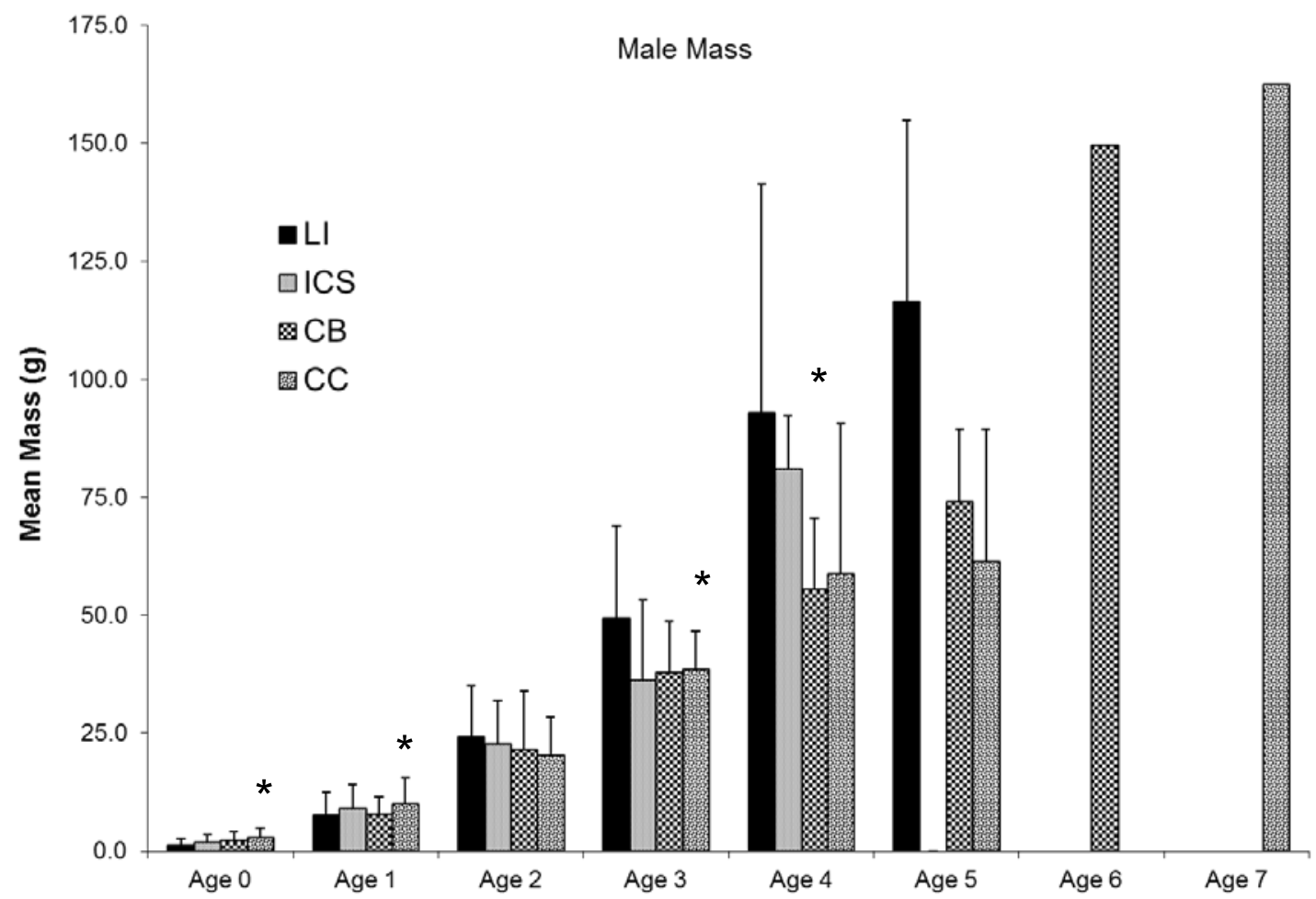

b

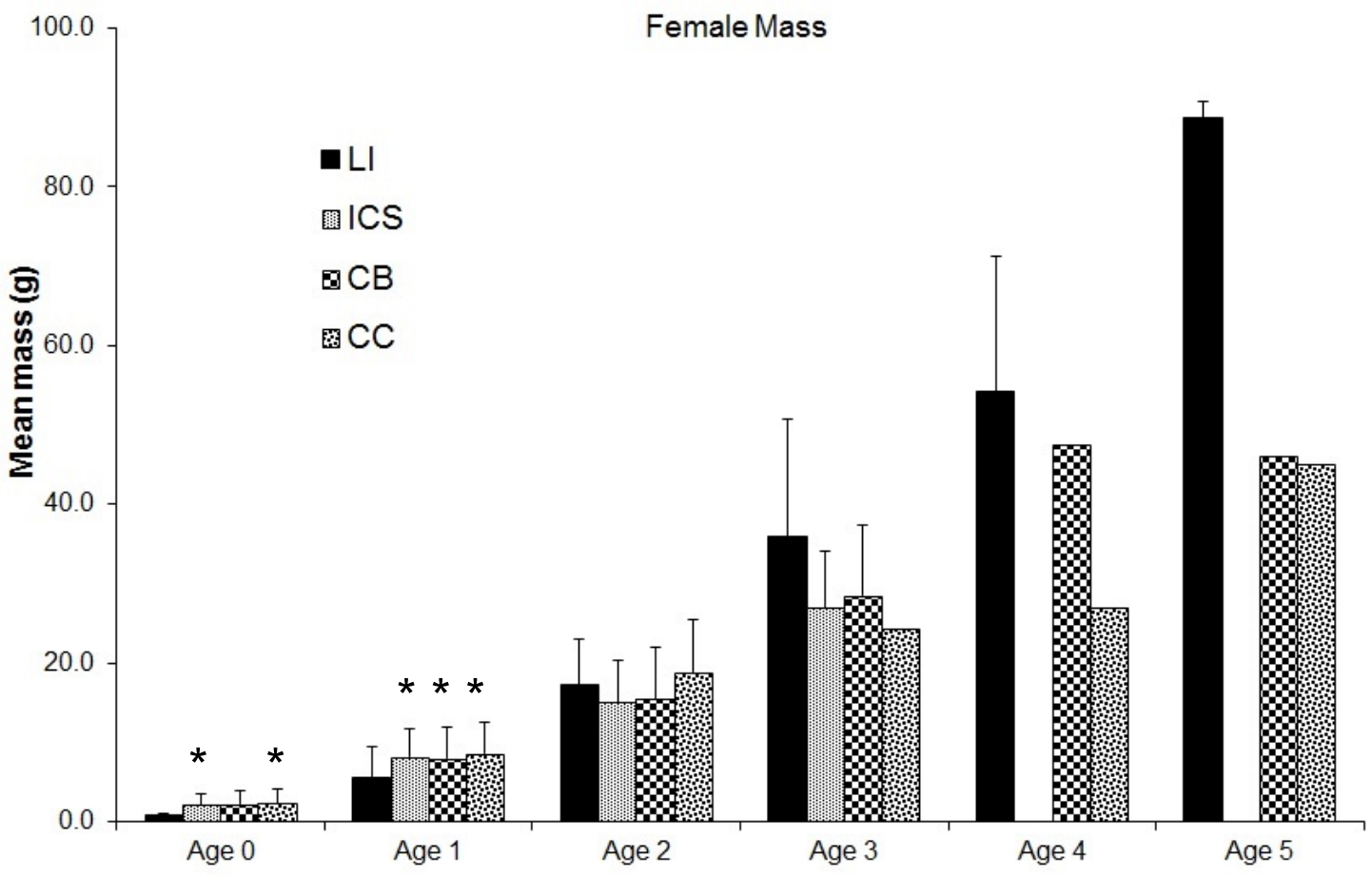




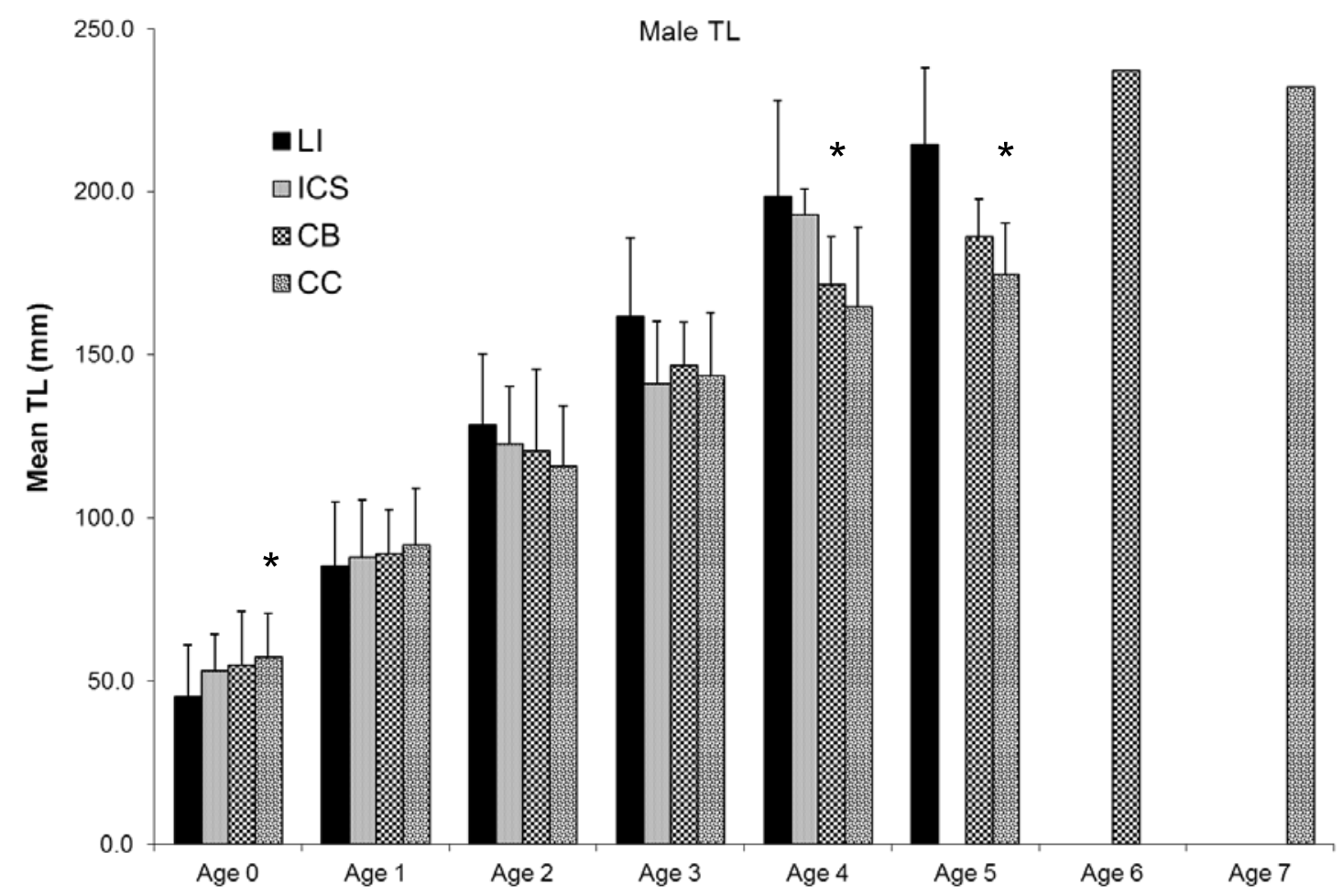

d

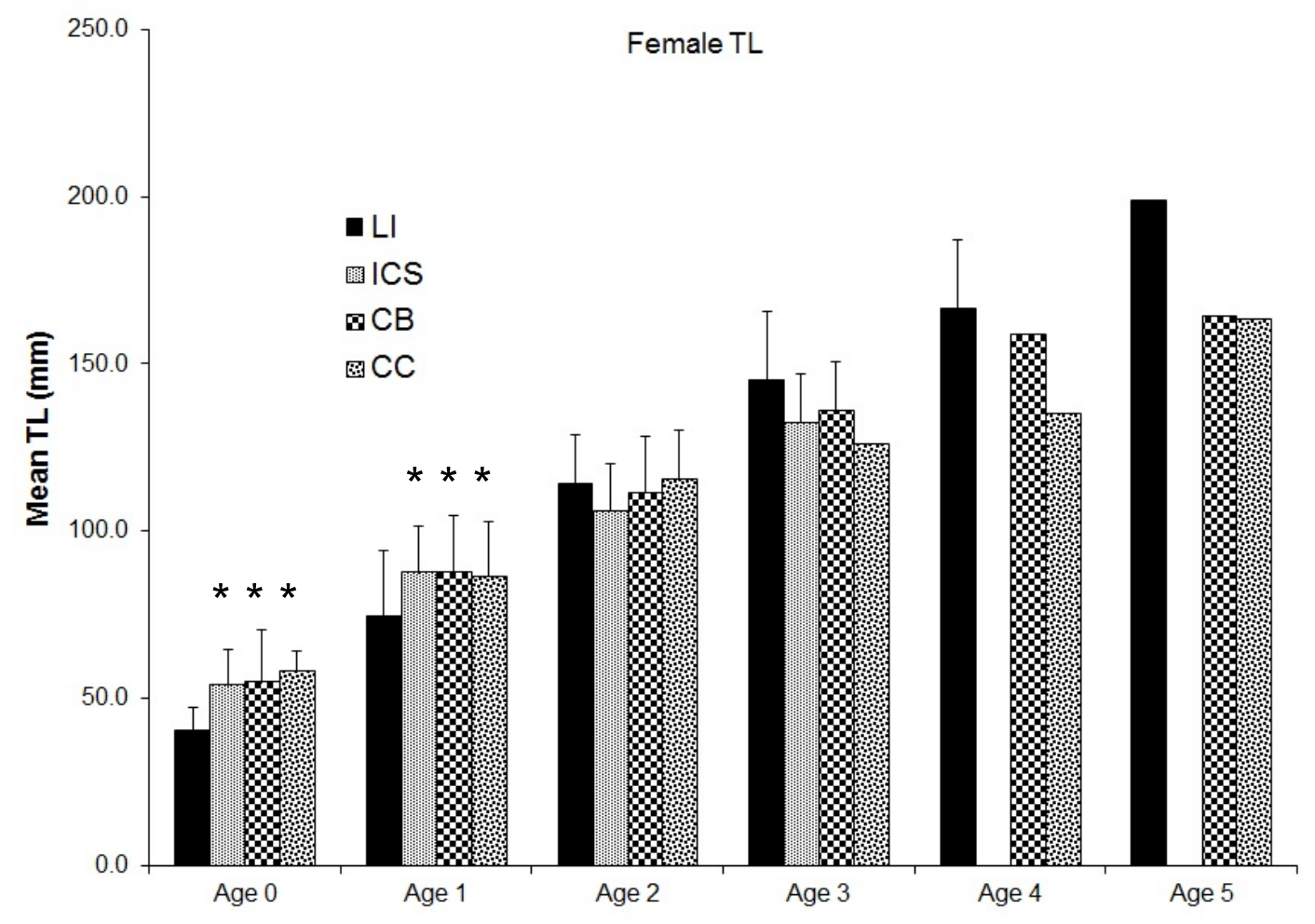


Fig. 3. Creek chub relative length frequency comparison for: a) Little Indian Creek (LI) reference site and upper Clear Creek (ICS), b) LI and Conards Branch/ Richland Creek (CB), and C) LI and lower Clear Creek (CC). 

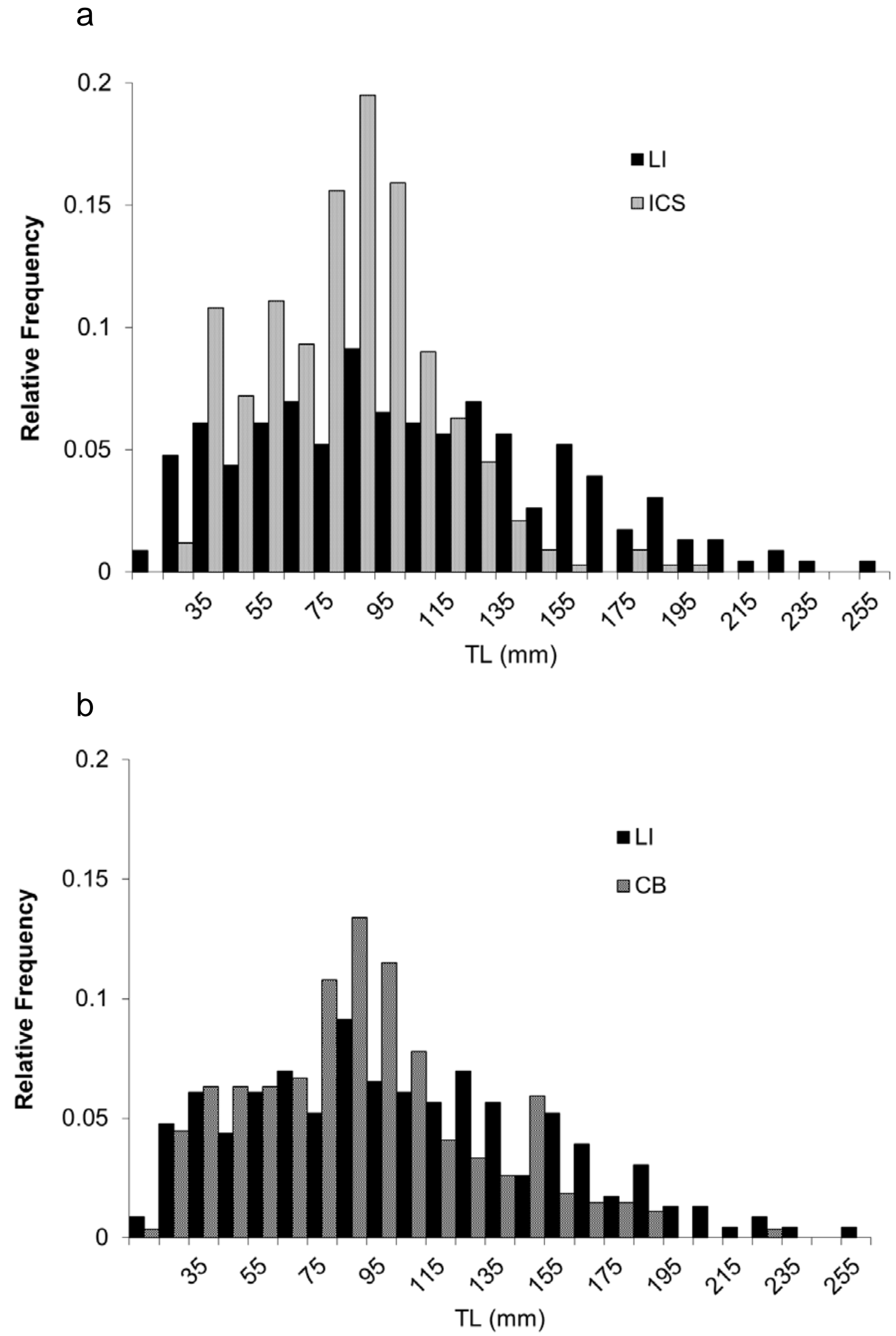


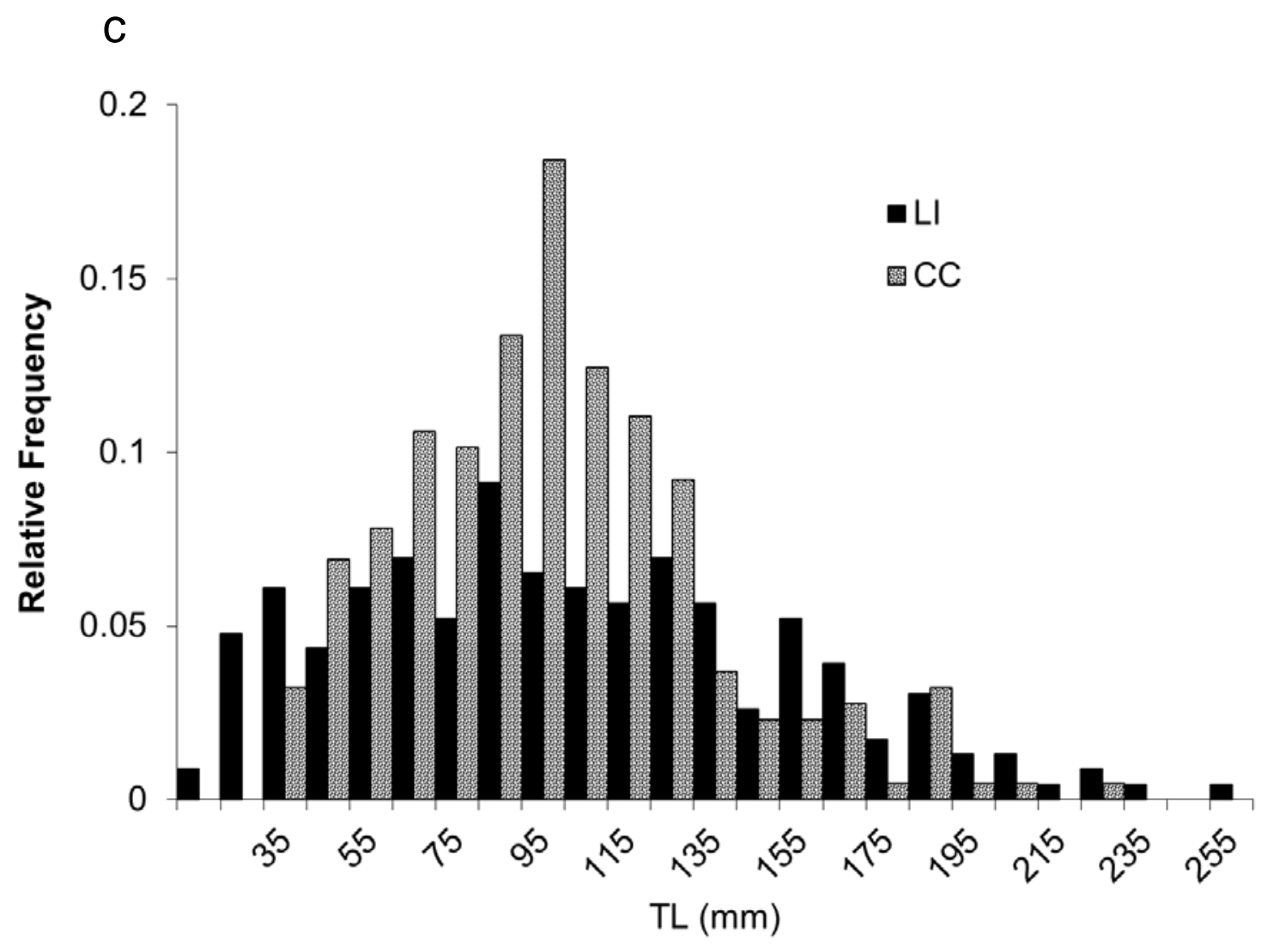


Table 1. Select physical habitat characteristics, habitat quality, biotic integrity and PCB concentrations (range, means $\pm S D$ ) in various media for three PCB contaminated sites and a reference site in the White River drainage, Indiana.

\begin{tabular}{|c|c|c|c|c|}
\hline & ICS & CB & $\mathrm{CC}$ & $\mathrm{LI}$ \\
\hline \multicolumn{5}{|l|}{ PCB Gradient } \\
\hline Classification & high & medium & low & reference \\
\hline Source of PCBs & Lemon Lane LF & Neals LF & Lemon Lane LF & none known \\
\hline Drainage area $\left(\mathrm{km}^{2}\right.$ & 6.0 & 1.2 & 16.3 & 27.5 \\
\hline $\begin{array}{c}\text { Substrate types } \\
(\%)\end{array}$ & $\begin{array}{l}\text { sand (40), } \\
\text { gravel (35), } \\
\text { cobble (20), } \\
\text { boulder (5) }\end{array}$ & $\begin{array}{l}\text { silt }(25), \\
\text { gravel }(25), \\
\text { cobble }(20), \\
\text { bedrock }(30)\end{array}$ & $\begin{array}{l}\text { sand (35), } \\
\text { gravel (30), } \\
\text { cobble (15), } \\
\text { boulder (15) }\end{array}$ & $\begin{array}{l}\text { sand }(5), \\
\text { gravel }(20), \\
\text { cobble }(60), \\
\text { boulder }(5), \\
\text { bedrock }(10)\end{array}$ \\
\hline Land use & urban/residential & agricultural & urban & agricultural \\
\hline Habitat & forest corridor & $\begin{array}{l}\text { pasture/forested } \\
\text { corridor }\end{array}$ & forested corridor & forested corridor \\
\hline Stream width $(\mathrm{m})$ & 2 & 4 & 3 & 6.5 \\
\hline QHEI & 51.2 & 58.4 & 40.6 & 55.2 \\
\hline Mean IBI & $\begin{array}{l}27.0 \\
\text { Poor }\end{array}$ & $\begin{array}{l}48.5 \\
\text { Good / Fair }\end{array}$ & $\begin{array}{l}34.0 \\
\text { Poor }\end{array}$ & $\begin{array}{l}46.5 \\
\text { Good / Fair }\end{array}$ \\
\hline $\begin{array}{l}\text { PCB groundwater } \\
\text { concentrations at } \\
\text { source }(\mathrm{ppb})\end{array}$ & $\begin{array}{l}4.7-470 \\
\text { (Tetra Tech, 2001) }\end{array}$ & $\begin{array}{l}0.13-8.7 \\
\text { (Tetra Tech, 2000) }\end{array}$ & $\begin{array}{l}4.7-470 \\
\text { (Tetra Tech, 2001) }\end{array}$ & NA \\
\hline $\begin{array}{l}\text { Ambient water at } \\
\text { Study area (ppb) }\end{array}$ & 1.1 (USEPA, 1992) & 0.46 (CBS, 1998) & $\begin{array}{c}<1.0 \text { (USEPA } \\
1992)\end{array}$ & NA \\
\hline Sediments (ppm) & $\begin{array}{l}4.3 \text { (Normandeau, } \\
1995 \text { ) } \\
2.17 \pm 0.26, \mathrm{n}=3 \\
\text { (Westinghouse } 1997\end{array}$ & $\begin{array}{l}1.87 \pm 0.93, n=5 \\
(C B S 1998) \\
7)\end{array}$ & $\begin{array}{l}0.58 \text { (Normandeau, } \\
1995 \text { ) } \\
0.56 \pm 0.14, \mathrm{n}=5 \\
\text { (Westinghouse 1997) }\end{array}$ & NA \\
\hline $\begin{array}{l}\text { Creek Chubs } \\
\text { (whole body, ppm) }\end{array}$ & $\begin{array}{l}19.2 \pm 3.18, n=9 \\
\text { (Westinghouse, } \\
1997 \text { ) }\end{array}$ & $\begin{array}{l}12.1 \pm 3.06, n=8 \\
(C B S, 1998)\end{array}$ & $\begin{array}{c}2.12 \pm 0.18, n=9 \\
\text { (Westinghouse, } \\
\text { 1997) }\end{array}$ & $\begin{array}{c}0.01 \pm 0.002, \mathrm{n}=6 \\
\text { (Henshel et al. } \\
2006)\end{array}$ \\
\hline
\end{tabular}

ICS, upper Clear Creek; CB, Conards Branch/Richland Creek; CC, lower Clear Creek; LI, Little Indian Creek; QHEI, Qualitative Habitat Evaluation Index; IBI, Index of Biotic Integrity; ppb, parts per billion; NA, not analyzed; ppm, parts per million; n, number of samples analyzed. 
Table 2. Creek chub scale - otolith ${ }^{1}$ age corroboration evaluation.

\begin{tabular}{|c|c|c|c|c|c|}
\hline $\begin{array}{l}\text { scale } \\
\text { age }\end{array}$ & $\begin{array}{l}\text { otolith } \\
\text { matches } \\
\text { scale }\end{array}$ & $\begin{array}{l}\text { otolith } 1 \\
\text { year less } \\
\text { than scale }\end{array}$ & $\begin{array}{l}\text { otolith } 1 \\
\text { year more } \\
\text { than scale }\end{array}$ & $\begin{array}{l}\# \text { in } \\
\text { age } \\
\text { class }\end{array}$ & $\begin{array}{l}\text { accuracy } \\
\text { by age } \\
\text { class }\end{array}$ \\
\hline 0 & 8 & & 2 & 10 & $80.0 \%$ \\
\hline 1 & 26 & & 1 & 27 & $96.3 \%$ \\
\hline 2 & 11 & & 2 & 13 & $84.6 \%$ \\
\hline 3 & 15 & & 1 & 16 & $93.8 \%$ \\
\hline 4 & 7 & & & 7 & $100.0 \%$ \\
\hline 5 & 5 & 1 & 1 & 7 & $71.4 \%$ \\
\hline \multirow[t]{2}{*}{6} & 1 & & & 1 & $100.0 \%$ \\
\hline & 73 & 1 & 7 & 81 & $90.1 \%$ \\
\hline
\end{tabular}

1 - Otoliths were embedded EpoxiCure2 (Buehler, Lake Bluff, IL) in silicone molds (Ted Pella, Inc., Redding, CA). Hardened epoxy blocks containing otoliths were cut on an SYJ150 precision low speed diamond saw (MTI Corp., Richmond, CA) and mounted onto glass microscope slides using Crystalbond 509-3 (Ted Pella, Inc., Redding, CA). These were hand polished using 1500 grit wet dry sandpaper (3M Corp., St. Paul, MN) and photographed using a Leica DFC425C digital camera affixed to a Leica microscope (Model DM2000, Heerbrugg, Switzerland) and using Leica Application Suite 3.8.0 imaging software. 
Table 3. Average creek chub body weight (BW) and total length (TL) differences by sex and site.

\begin{tabular}{|c|c|c|c|c|c|c|c|c|}
\hline \multicolumn{9}{|c|}{$\mathrm{TL}(\mathrm{mm})$} \\
\hline \multirow{2}{*}{$\begin{array}{l}\text { year } \\
\text { class }\end{array}$} & \multicolumn{2}{|r|}{$\mathrm{LI}^{\mathrm{a}}$} & \multicolumn{2}{|c|}{$\mathrm{ICS}^{\mathrm{b}}$} & \multicolumn{2}{|c|}{$\mathrm{CB}^{\mathrm{C}}$} & \multicolumn{2}{|c|}{$C C^{d}$} \\
\hline & $M^{e}$ & $F^{f}$ & $M$ & $\mathrm{~F}$ & $M$ & $\mathrm{~F}$ & $M$ & $\mathrm{~F}$ \\
\hline 0 & 46.6 & $41.1 \mathrm{~ns}$ & 53.9 & $55.4 \mathrm{~ns}$ & 55.1 & 54.6 ns & 61.2 & $57.9 \mathrm{~ns}$ \\
\hline 1 & 87.3 & $76.1(p<0.02)$ & 88.4 & $87.6 \mathrm{~ns}$ & 89.7 & $87.7 \mathrm{~ns}$ & 93.0 & $86.2(p<0.04)$ \\
\hline 2 & 130.1 & $114.0(p<0.001)$ & 123.3 & $106.3(p<0.001)$ & 119.5 & $112.8 \mathrm{~ns}$ & 118.9 & $115.3 \mathrm{~ns}$ \\
\hline 3 & 165.2 & $146.1(p<0.01)$ & 143.1 & $132.3 \mathrm{~ns}$ & 145.5 & $136.3 \mathrm{~ns}$ & 153.9 & $126.0(p<0.001)$ \\
\hline 4 & 198.5 & $163.2(p<0.008)$ & 192.7 & -- & 172.3 & $158.8(p<0.02)$ & 186.6 & $135.0(p<0.001)$ \\
\hline 5 & 211.6 & 199.0 ns & -- & -- & 191.0 & $164.0 \mathrm{~ns}$ & 174.6 & $163.0 \mathrm{~ns}$ \\
\hline
\end{tabular}

\begin{tabular}{|c|c|c|c|c|c|c|c|c|}
\hline \multirow{3}{*}{$\begin{array}{l}\text { year } \\
\text { class }\end{array}$} & \multirow{2}{*}{\multicolumn{2}{|c|}{$\mathrm{LI}$}} & \multicolumn{4}{|c|}{ BW (g) } & \multirow{2}{*}{\multicolumn{2}{|c|}{$\mathrm{CC}$}} \\
\hline & & & & ICS & & & & \\
\hline & $\mathrm{M}$ & $\mathrm{F}$ & M & $\mathrm{F}$ & M & $\mathrm{F}$ & $\mathrm{M}$ & $\mathrm{F}$ \\
\hline 0 & 1.4 & $0.8(p<0.06)$ & 2.1 & $2.4 \mathrm{~ns}$ & 2.3 & $2.4 \mathrm{~ns}$ & 2.8 & $2.3 \mathrm{~ns}$ \\
\hline 1 & 7.9 & $5.8(p<0.04)$ & 9.2 & $8.3 \mathrm{~ns}$ & 8.1 & $8.0 \mathrm{~ns}$ & 10.5 & $8.6(p<0.04)$ \\
\hline 2 & 24.9 & $17.2(p<0.001)$ & 23.3 & $15.0(p<0.001)$ & 21.2 & $16.2(p<0.06)$ & 21.1 & $18.8 \mathrm{~ns}$ \\
\hline 3 & 51.5 & $36.2(p<0.01)$ & 37.4 & $27.0 \mathrm{~ns}$ & 36.0 & 31.1 ns & 45.2 & $24.4(p<0.001)$ \\
\hline 4 & 92.9 & $52.0(p<0.03)$ & 81.2 & -- & 55.5 & $47.6 \mathrm{~ns}$ & 89.3 & $27.0(p<0.003)$ \\
\hline 5 & 112.1 & $88.8 \mathrm{~ns}$ & -- & -- & 56.7 & $46.0 \mathrm{~ns}$ & 61.5 & $45.1 \mathrm{~ns}$ \\
\hline
\end{tabular}

a - LI, Little Indian Creek (reference site); ${ }^{b}$ - ICS, upper Clear Creek (high PCBs); ${ }^{c}$ - CB, Conards Branch/Richland Creek (medium PCBs); ${ }^{d}-$ CC, lower Clear Creek (low PCBs); ${ }^{e}-M$, male (see Table 4 for sample sizes); ${ }^{\dagger}-\mathrm{F}$, female; (see Table 5 for sample sizes). 
Table 4. Regression equations for creek chub body weight (BW) and total length (TL) by site and sex.

\begin{tabular}{|c|c|c|c|c|}
\hline Site & $\operatorname{Sex}^{a}$ & $\mathrm{BW}(\mathrm{g})$ & $\mathrm{TL}(\mathrm{mm})$ & $\mathrm{N}^{\mathrm{b}}$ \\
\hline $\mathrm{LI}^{\mathrm{C}}$ & $\mathrm{F}$ & $14.8 *$ years $-8.0 \quad\left(p<0.0001 ; R^{2}=0.79\right) A^{d}$ & $\left(p<0.0001 ; R^{2}=0.83\right) A$ & 101 \\
\hline $\operatorname{ICS}^{\mathrm{e}}$ & $\mathrm{F}$ & 7.0 * years $+1.6 \quad\left(p<0.0001 ; R^{2}=0.64\right) B$ & $\left(p<0.0001 ; R^{2}=0.65\right) B$ & 224 \\
\hline $\mathrm{CB}^{f}$ & $\mathrm{~F}$ & $9.3 *$ years $-0.1 \quad\left(p<0.0001 ; R^{2}=0.74\right) B$ & $\left(p<0.0001 ; R^{2}=0.71\right) B$ & 127 \\
\hline $\mathrm{CC}^{\mathrm{g}}$ & $\mathrm{F}$ & 8.0 * years $+1.4 \quad\left(p<0.0001 ; R^{2}=0.65\right) B$ & 22.6 * years $+64.1 \quad\left(p<0.0001 ; R^{2}=0.64\right) B$ & 107 \\
\hline LI & M & $23.1 *$ years $-12.4\left(p<0.0001 ; R^{2}=0.71\right) A$ & $\left(p<0.0001 ; R^{2}=0.85\right) A$ & 119 \\
\hline ICS & M & 14.6 * years $-3.5 \quad\left(p<0.0001 ; R^{2}=0.70\right) B$ & $\left(p<0.0001 ; R^{2}=0.77\right)$ & 161 \\
\hline $\mathrm{CB}$ & M & 14.4 * years $-3.6 \quad\left(p<0.0001 ; R^{2}=0.77\right) B$ & $\left(p<0.0001 ; R^{2}=0.81\right) B$ & 132 \\
\hline $\mathrm{CC}$ & M & 17.0 * years $-5.6 \quad\left(p<0.0001 ; R^{2}=0.71\right) B$ & 26.3 * years $+66.7 \quad\left(p<0.0001 ; R^{2}=0.77\right) B$ & 152 \\
\hline LI & $\mathrm{F}$ & $1.1 *$ months $-10.4\left(p<0.0001 ; R^{2}=0.75\right) A$ & $\left(p<0.0001 ; R^{2}=0.83\right) A$ & 101 \\
\hline ICS & $\mathrm{F}$ & $0.6 *$ months $-0.7 \quad\left(p<0.0001 ; R^{2}=0.73\right) B$ & $\left(p<0.0001 ; R^{2}=0.77\right) B$ & 224 \\
\hline $\mathrm{CB}$ & $\mathrm{F}$ & $0.7 *$ months $-3.4\left(p<0.0001 ; R^{2}=0.70\right) B$ & $\left(p<0.0001 ; R^{2}=0.71\right) B$ & 127 \\
\hline $\mathrm{CC}$ & $\mathrm{F}$ & $0.6 *$ months $-1.1\left(p<0.0001 ; R^{2}=0.69\right) B$ & $\left(p<0.0001 ; R^{2}=0.70\right) B$ & 107 \\
\hline LI & M & $1.8 *$ months $-19.1\left(p<0.0001 ; R^{2}=0.71\right) A$ & $\left(p<0.0001 ; R^{2}=0.84\right) A$ & 119 \\
\hline ICS & M & $1.1 *$ months $-7.1\left(p<0.0001 ; R^{2}=0.70\right) B$ & $\left(p<0.0001 ; R^{2}=0.84\right)$ & 161 \\
\hline $\mathrm{CB}$ & M & $1.2 *$ months $-9.9\left(p<0.0001 ; R^{2}=0.71\right) B$ & $\left(p<0.0001 ; R^{2}=0.81\right) B$ & 132 \\
\hline $\mathrm{CC}$ & M & $1.4 *$ months $-12.2\left(p<0.0001 ; R^{2}=0.71\right) B$ & $2.2 *$ months $+55.3 \quad\left(p<0.0001 ; R^{2}=0.80\right) B$ & 152 \\
\hline
\end{tabular}

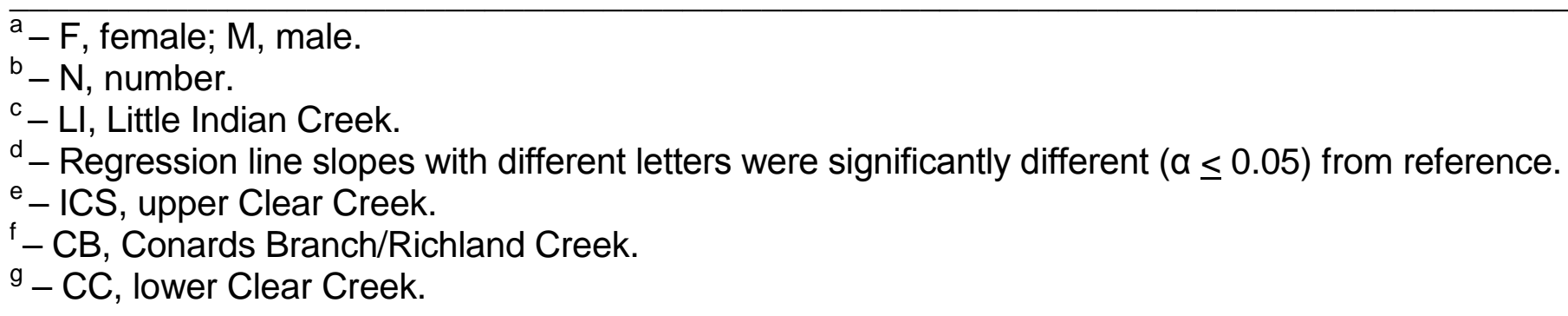


Table 5. Male creek chub mean calculated total length ( $T L)$ at successive annuli by age class.

\begin{tabular}{|c|c|c|c|c|c|c|c|c|c|c|}
\hline \multirow[b]{2}{*}{ Site } & \multirow[b]{2}{*}{ Age } & \multirow[b]{2}{*}{$\mathrm{N}$} & \multirow{2}{*}{$\begin{array}{l}\text { mean } \\
\text { TL at } \\
\text { capture }\end{array}$} & \multicolumn{6}{|c|}{ mean calculated TL at successive annuli } & \multirow[b]{2}{*}{7} \\
\hline & & & & 1 & 2 & 3 & 4 & 5 & 6 & \\
\hline $\mathrm{LI}$ & 0 & 17 & 45.1 & & & & & & & \\
\hline LI & 1 & 35 & 85.2 & 48.4 & & & & & & \\
\hline LI & 2 & 31 & 128.5 & 50.3 & 93.1 & & & & & \\
\hline LI & 3 & 18 & 161.8 & 42.9 & 83.0 & 126.3 & & & & \\
\hline $\mathrm{LI}$ & 4 & 10 & 198.5 & 42.9 & 79.3 & 119.1 & 160.9 & & & \\
\hline $\mathrm{LI}$ & 5 & 8 & 214.5 & 39.6 & 70.9 & 101.0 & 136.9 & 178.3 & & \\
\hline LI & 6 & 0 & & & & & & & & \\
\hline ICS & 0 & 32 & 53.1 & & & & & & & \\
\hline ICS & 1 & 78 & 87.9 & 50.2 & & & & & & \\
\hline ICS & 2 & 36 & 122.5 & 45.1 & 85.9 & & & & & \\
\hline ICS & 3 & 11 & 141.0 & 40.6 & 77.6 & 116.7 & & & & \\
\hline ICS & 4 & 4 & 192.8 & 53.1 & 87.2 & 128.9 & 160.2 & & & \\
\hline ICS & 5 & 0 & & & & & & & & \\
\hline CB & 0 & 31 & 54.7 & & & & & & & \\
\hline CB & 1 & 43 & 89.2 & 46.8 & & & & & & \\
\hline CB & 2 & 32 & 119.6 & 45.1 & 83.5 & & & & & \\
\hline CB & 3 & 9 & 145.5 & 40.0 & 79.7 & 125.7 & & & & \\
\hline CB & 4 & 12 & 172.3 & 39.8 & 64.4 & 98.9 & 128.0 & & & \\
\hline CB & 5 & 3 & 186.0 & 30.8 & 54.0 & 83.2 & 111.6 & 147.4 & & \\
\hline CB & 6 & 1 & 237.0 & 20.3 & 33.1 & 46.0 & 87.5 & 110.4 & 163.5 & \\
\hline CC & 0 & 10 & 57.3 & & & & & & & \\
\hline CC & 1 & 50 & 91.5 & 50.1 & & & & & & \\
\hline CC & 2 & 30 & 115.8 & 43.1 & 87.3 & & & & & \\
\hline CC & 3 & 20 & 143.5 & 44.9 & 88.5 & 129.2 & & & & \\
\hline $\mathrm{CC}$ & 4 & 7 & 164.6 & 40.1 & 68.1 & 105.3 & 148.8 & & & \\
\hline CC & 5 & 5 & 174.6 & 40.0 & 67.7 & 89.1 & 121.4 & 154.9 & & \\
\hline CC & 6 & 0 & & & & & & & & \\
\hline CC & 7 & 1 & 232.0 & 35.4 & 59.8 & 89.6 & 124.8 & 155.7 & 185.2 & 210.3 \\
\hline CC & 8 & 0 & & & & & & & & \\
\hline
\end{tabular}

LI, Little Indian Creek; ICS, upper Clear Creek; CB, Conards Branch/Richland Creek; CC, lower Clear Creek; N, number; TL, total length in $\mathrm{mm}$. 
Table 6. Female creek chub mean calculated total length (TL) at successive annuli by age class.

\begin{tabular}{|c|c|c|c|c|c|c|c|c|c|}
\hline \multirow[b]{2}{*}{ Site } & \multirow[b]{2}{*}{ Age } & \multirow[b]{2}{*}{$\mathrm{N}$} & \multirow{2}{*}{$\begin{array}{l}\text { mean } \\
\text { TL at } \\
\text { capture }\end{array}$} & \multicolumn{6}{|c|}{ mean calculated TL at successive annuli } \\
\hline & & & & $\overline{1}$ & 2 & 3 & 4 & 5 & 6 \\
\hline $\mathrm{LI}$ & 0 & 9 & 40.4 & & & & & & \\
\hline LI & 1 & 43 & 74.7 & 47.1 & & & & & \\
\hline LI & 2 & 25 & 114.0 & 40.9 & 84.7 & & & & \\
\hline LI & 3 & 14 & 145.3 & 41.3 & 75.2 & 117.3 & & & \\
\hline LI & 4 & 8 & 166.8 & 45.1 & 78.4 & 113.4 & 142.9 & & \\
\hline LI & 5 & 2 & 199.0 & 40.7 & 70.0 & 111.6 & 143.8 & 171.8 & \\
\hline LI & 6 & 0 & & & & & & & \\
\hline ICS & 0 & 48 & 53.7 & & & & & & \\
\hline ICS & 1 & 114 & 87.4 & 52.0 & & & & & \\
\hline ICS & 2 & 54 & 106.0 & 44.3 & 82.7 & & & & \\
\hline ICS & 3 & 8 & 132.3 & 38.0 & 77.5 & 107.3 & & & \\
\hline ICS & 4 & 0 & & & & & & & \\
\hline CB & 0 & 29 & 54.6 & & & & & & \\
\hline CB & 1 & 57 & 87.6 & 50.1 & & & & & \\
\hline CB & 2 & 32 & 112.8 & 44.0 & 83.4 & & & & \\
\hline CB & 3 & 3 & 136.3 & 45.2 & 86.2 & 114.7 & & & \\
\hline CB & 4 & 5 & 158.8 & 43.7 & 67.1 & 100.0 & 129.5 & & \\
\hline CB & 5 & 2 & 164.0 & 33.3 & 60.9 & 86.8 & 112.4 & 145.3 & \\
\hline CB & 6 & 0 & & & & & & & \\
\hline CC & 0 & 11 & 57.9 & & & & & & \\
\hline CC & 1 & 54 & 86.2 & 49.6 & & & & & \\
\hline CC & 2 & 32 & 115.3 & 45.5 & 85.2 & & & & \\
\hline CC & 3 & 7 & 126.0 & 40.6 & 70.8 & 103.4 & & & \\
\hline CC & 4 & 2 & 135.0 & 37.8 & 61.0 & 83.6 & 111.1 & & \\
\hline CC & 5 & 1 & 163.0 & 40.9 & 69.3 & 92.2 & 111.2 & 135.9 & \\
\hline CC & 6 & 0 & & & & & & & \\
\hline
\end{tabular}

LI, Little Indian Creek; ICS, upper Clear Creek; CB, Conards Branch/Richland Creek; CC, lower Clear Creek; N, number; TL, total length in $\mathrm{mm}$. 
Table 7. Mean male and female creek chub instantaneous growth rates by age class.

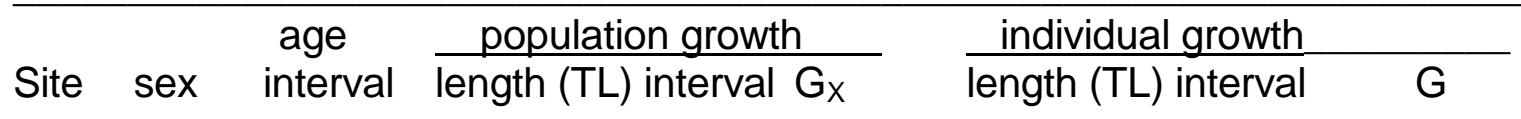

\begin{tabular}{llrrrrr}
\hline $\mathrm{LI}$ & $\mathrm{M}$ & $1-2$ & $48.4-93.7$ & 1.85 & $49.9-93.7$ & 1.74 \\
$\mathrm{LI}$ & $\mathrm{M}$ & $2-3$ & $93.7-128.6$ & 0.88 & $84.2-128.6$ & 1.21 \\
$\mathrm{LI}$ & $\mathrm{M}$ & $3-4$ & $128.6-160.9$ & 0.71 & $119.1-160.9$ & 0.88 \\
$\mathrm{LI}$ & $\mathrm{M}$ & $4-5$ & $160.9-178.3$ & 0.30 & $136.9-178.3$ & 0.78 \\
& & & & & & \\
ICS & $\mathrm{M}$ & $1-2$ & $50.2-85.9$ & 1.58 & $45.1-85.9$ & 1.90 \\
ICS & $\mathrm{M}$ & $2-3$ & $85.9-116.7$ & 0.89 & $77.6-116.7$ & 1.18 \\
$\mathrm{ICS}$ & $\mathrm{M}$ & $3-4$ & $116.7-160.2$ & 0.94 & $128.9-160.2$ & 0.64 \\
& & & & & & \\
$\mathrm{CB}$ & $\mathrm{M}$ & $1-2$ & $46.8-83.5$ & 1.75 & $45.1-83.5$ & 1.86 \\
$\mathrm{CB}$ & $\mathrm{M}$ & $2-3$ & $83.5-125.7$ & 1.26 & $79.7-125.7$ & 1.41 \\
$\mathrm{CB}$ & $\mathrm{M}$ & $3-4$ & $125.7-128.0$ & 0.06 & $98.9-128.0$ & 0.89 \\
$\mathrm{CB}$ & $\mathrm{M}$ & $4-5$ & $128.0-147.4$ & 0.45 & $111.6-147.4$ & 0.90 \\
& & & & & & \\
$\mathrm{CC}$ & $\mathrm{M}$ & $1-2$ & $50.1-87.3$ & 1.56 & $50.5-88.3$ & 2.11 \\
$\mathrm{CC}$ & $\mathrm{M}$ & $2-3$ & $87.3-129.2$ & 1.03 & $88.3-126.9$ & 1.09 \\
$\mathrm{CC}$ & $\mathrm{M}$ & $3-4$ & $129.2-148.8$ & 0.39 & $126.9-131.9$ & 1.16 \\
$\mathrm{CC}$ & $\mathrm{M}$ & $4-5$ & $148.8-154.9$ & 0.15 & $131.9-153.2$ & 0.90 \\
& & & & & & \\
$\mathrm{LI}$ & $\mathrm{F}$ & $1-2$ & $47.1-84.7$ & 1.74 & $40.9-84.7$ & 2.16 \\
$\mathrm{LI}$ & $\mathrm{F}$ & $2-3$ & $84.7-117.3$ & 0.96 & $75.2-117.3$ & 1.31 \\
$\mathrm{LI}$ & $\mathrm{F}$ & $3-4$ & $117.3-142.9$ & 0.68 & $113.4-142.9$ & 0.80 \\
$\mathrm{LI}$ & $\mathrm{F}$ & $4-5$ & $142.9-171.8$ & 0.54 & $143.8-171.8$ & 0.52 \\
& & & & & & \\
ICS & $\mathrm{F}$ & $1-2$ & $52.0-82.7$ & 1.33 & $44.3-82.7$ & 1.79 \\
$\mathrm{ICS}$ & $\mathrm{F}$ & $2-3$ & $82.7-107.3$ & 0.74 & $77.5-107.3$ & 0.93 \\
& & & & & & \\
$\mathrm{CB}$ & $\mathrm{F}$ & $1-2$ & $50.1-83.4$ & 1.53 & $44.4-83.4$ & 1.90 \\
$\mathrm{CB}$ & $\mathrm{F}$ & $2-3$ & $83.4-114.7$ & 0.92 & $86.2-114.7$ & 0.83 \\
$\mathrm{CB}$ & $\mathrm{F}$ & $3-4$ & $114.7-129.5$ & 0.30 & $100.0-129.5$ & 0.64 \\
$\mathrm{CB}$ & $\mathrm{F}$ & $4-5$ & $129.5-145.3$ & 0.47 & $112.4-145.3$ & 1.06 \\
& & & & & & \\
$\mathrm{CC}$ & $\mathrm{F}$ & $1-2$ & $49.8-85.2$ & 1.52 & $45.5-85.2$ & 1.76 \\
$\mathrm{CC}$ & $\mathrm{F}$ & $2-3$ & $85.2-103.4$ & 0.66 & $70.8-103.4$ & 1.30 \\
$\mathrm{CC}$ & $\mathrm{F}$ & $3-4$ & $103.4-111.1$ & 0.22 & $83.6-111.1$ & 0.89 \\
$\mathrm{CC}$ & $\mathrm{F}$ & $4-5$ & $111.1-135.9$ & - & $111.2-135.9$ & -
\end{tabular}

LI, Little Indian Creek; ICS, upper Clear Creek; CB, Conards Branch/Richland Creek; CC, lower Clear Creek; TL, total length in $\mathrm{mm} ; \mathrm{G}_{\mathrm{x}}$, population instantaneous growth rate; $\mathrm{G}$, individual instantaneous growth rate. 
Table 8. Male creek chub weight-length regressions by age class.

\begin{tabular}{|c|c|c|c|c|c|c|c|c|}
\hline \multirow{3}{*}{ Site } & \multirow[b]{2}{*}{ Age } & \multirow[b]{2}{*}{$\mathrm{N}$} & \multirow{2}{*}{\multicolumn{2}{|c|}{$\frac{\text { Means }}{\log T L \log B W}$}} & \multicolumn{2}{|c|}{ Regression } & \multirow[b]{2}{*}{$S$} & \multirow{2}{*}{$\begin{array}{l}\text { Functional } \\
\text { intercept } \\
\text { log a }\end{array}$} \\
\hline & & & & & ordinary & $\begin{array}{c}\text { Functional } \\
\text { b }\end{array}$ & & \\
\hline & 1 & 35 & 1.92 & 0.79 & 2.80 & 2.83 & 0.26 & -4.64 \\
\hline LI & 2 & 31 & 2.10 & 1.33 & 2.83 & 2.87 & 0.18 & -4.70 \\
\hline LI & 3 & 18 & 2.20 & 1.65 & 2.87 & 2.94 & 0.16 & -4.83 \\
\hline LI & 4 & 10 & 2.29 & 1.93 & 2.89 & 2.96 & 0.05 & -4.85 \\
\hline LI & 5 & 8 & 2.33 & 2.05 & 2.71 & 2.91 & 0.05 & -4.74 \\
\hline \multicolumn{3}{|c|}{ LI all 1+ unweighted } & 2.13 & 1.43 & 2.82 & 2.90 & 0.14 & -4.75 \\
\hline \multicolumn{2}{|c|}{ LI all 1+ } & 102 & 2.09 & 1.32 & 2.99 & 3.00 & 0.40 & -4.97 \\
\hline ICS & 1 & 78 & 1.94 & 0.88 & 2.60 & 2.94 & 0.23 & -4.81 \\
\hline ICS & 2 & 36 & 2.08 & 1.32 & 2.75 & 2.89 & 0.14 & -4.70 \\
\hline ICS & 3 & 11 & 2.15 & 1.53 & 2.81 & 2.97 & 0.14 & -4.84 \\
\hline ICS & 4 & 4 & 2.29 & 1.91 & 3.17 & 3.27 & 0.04 & -5.57 \\
\hline \multicolumn{4}{|c|}{ ICS all 1+ unweighted 2.11} & 1.41 & 2.99 & 3.18 & 0.15 & -5.33 \\
\hline \multicolumn{2}{|c|}{ ICS all $1+$} & 129 & 2.01 & 1.09 & 2.84 & 2.96 & 0.30 & -4.84 \\
\hline CB & 1 & 43 & 1.95 & 0.85 & 2.94 & 3.03 & 0.17 & -5.04 \\
\hline $\mathrm{CB}$ & 2 & 32 & 2.07 & 1.23 & 3.05 & 3.09 & 0.26 & -5.15 \\
\hline CB & 3 & 9 & 2.16 & 1.54 & 3.14 & 3.47 & 0.12 & -5.96 \\
\hline CB & 4 & 12 & 2.24 & 1.74 & 3.07 & 3.22 & 0.03 & -5.47 \\
\hline CB & 5 & 3 & 2.27 & 1.87 & 2.14 & 2.38 & 0.08 & -3.53 \\
\hline CB & 6 & 1 & 2.38 & 2.18 & & & & \\
\hline \multicolumn{3}{|c|}{ CB all 1+ unweighted } & 2.17 & 1.55 & 2.87 & 3.04 & 0.13 & -5.03 \\
\hline \multicolumn{2}{|c|}{ CB all $1+$} & 101 & 2.05 & 1.19 & 3.07 & 3.09 & 0.34 & -5.17 \\
\hline $\mathrm{CC}$ & 1 & 58 & 1.96 & 0.96 & 2.60 & 2.82 & 0.22 & -4.56 \\
\hline $\mathrm{CC}$ & 2 & 36 & 2.07 & 1.29 & 2.53 & 2.64 & 0.15 & -4.19 \\
\hline $\mathrm{CC}$ & 3 & 24 & 2.19 & 1.64 & 2.44 & 2.79 & 0.14 & -4.47 \\
\hline $\mathrm{CC}$ & 4 & 7 & 2.27 & 1.92 & 3.60 & 3.68 & 0.07 & -6.44 \\
\hline $\mathrm{CC}$ & 5 & 5 & 2.24 & 1.77 & 4.72 & 5.11 & 0.08 & -9.68 \\
\hline $\mathrm{CC}$ & 6 & 0 & - & - & & & & \\
\hline CC & 7 & 1 & 2.37 & 2.21 & & & & \\
\hline \multicolumn{3}{|c|}{ CC all 1+ unweighted } & 2.18 & 1.63 & 3.18 & 3.41 & 0.13 & -5.87 \\
\hline \multicolumn{2}{|c|}{ CC all 1+ } & 131 & 2.06 & 1.26 & 2.87 & 2.95 & 0.31 & -4.82 \\
\hline
\end{tabular}


Table 9. Female creek chub weight-length regressions by age class.

\begin{tabular}{|c|c|c|c|c|c|c|c|c|}
\hline \multirow{2}{*}{ Site } & \multirow[b]{2}{*}{ Age } & \multirow[b]{2}{*}{$\mathrm{N}$} & \multirow{2}{*}{\multicolumn{2}{|c|}{$\frac{\text { Means }}{\log T L \log B W}$}} & \multicolumn{2}{|c|}{ Regression } & \multirow[b]{2}{*}{$S$} & \multirow{2}{*}{$\begin{array}{l}\text { Functional } \\
\text { intercept } \\
\text { log a }\end{array}$} \\
\hline & & & & & ordinary & $\begin{array}{c}\text { Functional } \\
\mathrm{b}\end{array}$ & & \\
\hline & 1 & 43 & 1.86 & 0.63 & 2.94 & 2.97 & 0.31 & -4.88 \\
\hline LI & 2 & 25 & 2.05 & 1.21 & 2.84 & 2.91 & 0.14 & -4.76 \\
\hline $\mathrm{LI}$ & 3 & 14 & 2.16 & 1.52 & 3.07 & 3.20 & 0.16 & -5.38 \\
\hline LI & 4 & 8 & 2.22 & 1.72 & 2.78 & 2.90 & 0.05 & -4.73 \\
\hline LI & 5 & 2 & 2.30 & 1.95 & & & & \\
\hline \multicolumn{3}{|c|}{ LI all 1+ unweighted } & 2.12 & 1.41 & 2.91 & 2.99 & 0.17 & -4.94 \\
\hline \multicolumn{2}{|c|}{ LI all 1+ } & 92 & 2.00 & 1.05 & 2.97 & 2.98 & 0.41 & -4.91 \\
\hline ICS & 1 & 114 & 1.93 & 0.87 & 2.79 & 2.87 & 0.17 & -4.67 \\
\hline ICS & 2 & 54 & 2.02 & 1.15 & 2.73 & 2.86 & 0.14 & -4.64 \\
\hline ICS & 3 & 8 & 2.12 & 1.42 & 1.75 & 2.03 & 0.06 & -2.89 \\
\hline \multicolumn{3}{|c|}{ ICS all 1+ unweighted } & 2.03 & 1.15 & 2.43 & 2.59 & 0.12 & -4.07 \\
\hline \multicolumn{2}{|c|}{ ICS all 1+ } & 176 & 1.97 & 0.98 & 2.89 & 2.95 & 0.21 & -4.83 \\
\hline $\mathrm{CB}$ & 1 & 58 & 1.94 & 0.83 & 2.95 & 3.01 & 0.24 & -4.99 \\
\hline $\mathrm{CB}$ & 2 & 30 & 2.04 & 1.15 & 2.69 & 2.90 & 0.17 & -4.78 \\
\hline CB & 3 & 4 & 2.13 & 1.44 & 1.76 & 2.48 & 0.16 & -3.81 \\
\hline $\mathrm{CB}$ & 4 & 4 & 2.20 & 1.68 & 3.78 & 4.14 & 0.03 & -7.46 \\
\hline CB & 5 & 2 & 2.21 & 1.65 & & & & \\
\hline \multicolumn{3}{|c|}{ CB all 1+ unweighted } & 2.10 & 1.35 & 2.80 & 3.13 & 0.15 & -5.26 \\
\hline \multicolumn{2}{|c|}{ CB all 1+ } & 98 & 2.00 & 1.02 & 2.97 & 3.02 & 0.29 & -5.01 \\
\hline $\mathrm{CC}$ & 1 & 54 & 1.93 & 0.88 & 2.70 & 2.81 & 0.21 & -4.54 \\
\hline CC & 2 & 32 & 2.06 & 1.24 & 2.47 & 3.43 & 0.17 & -5.84 \\
\hline CC & 3 & 7 & 2.10 & 1.38 & 2.71 & 3.12 & 0.09 & -5.18 \\
\hline CC & 4 & 2 & 2.13 & 1.42 & & & & \\
\hline $\mathrm{CC}$ & 5 & 1 & 2.21 & 1.65 & & & & \\
\hline \multicolumn{3}{|c|}{ CC all 1+ unweighted } & 2.09 & 1.31 & 2.63 & 3.12 & 0.16 & -5.18 \\
\hline CC all $]$ & & 96 & 1.99 & 1.05 & 2.71 & 2.84 & 0.26 & -4.60 \\
\hline
\end{tabular}


Chapter 5 - Patterns in stream fish assemblage structure and function associated with a PCB-gradient

\begin{abstract}
Stream fish assemblage structure and function were examined for significant response along a PCB gradient from two PCB contaminated streams (Clear Creek and Richland Creek watershed) at three locations and a reference stream (Little Indian Creek), Indiana, U.S.A. Fish were sampled in the summer months of 1995, and 1999-2002. Fifty-one fish assemblage attributes were evaluated including structure (i.e., fish composition) and function (i.e., trophic, reproductive, condition guilds), biomass, and index of biotic integrity (IBI) metric scores for significance to an increasing PCB gradient. Eight biomass attributes of fish assemblages declined with increasing PCB concentration including the number of species biomass (BIOSPP), number of sunfish biomass (BIOSUN), percent sunfish biomass (PBIOSUN), number of sucker biomass (BIOSUC), percent sucker biomass (PBIOSUC), biomass of sensitive species (BIOSEN), percent sensitive species biomass (PBIOSEN) and percent carnivore biomass (PBIOCARN). Three biomass attributes increased with PCB concentration including percent minnow biomass (PBIOMIN), percent pioneer species biomass (PBIOPIO), and percent tolerant species biomass (PBIOTOL). Seven species composition and relative abundance characters declined with increasing PCB concentration including, number of species (NUMSPP), number of darter, madtom and sculpin (NUMDMS); number of darter (NUMD), number of sunfish (NUMSUN), number of sucker (NUMSUC), number of sensitive species (NUMSEN) and percent individuals as carnivores (PERCARN). Percent individuals as
\end{abstract}


pioneer species (PERPIO) increased with increasing PCB concentration. Two IBI metrics, percent individuals as headwater species (M-PERHW) and number of minnow species (M-NUMMIN) increased as PCB concentrations increased, while number of sucker species (M-NUMSUC) and percent individuals as pioneer species (M-PERPIO) declined with increasing PCB concentration class. We observed a direct response between the reduced relative abundance and biomass of carnivores and an increase in the relative abundance of minnows as the PCB gradient increased. Total IBI score did not detect subtle changes to the fish community that were observed along a PCB gradient while diagnostic analysis of the individual metrics did.

\section{Introduction}

The index of biotic integrity (IBI) has been widely used to monitor the biological condition of aquatic systems as required by the Clean Water Act (CWA) of 1972. It uses several measures of species diversity and abundance, and trophic composition (Karr et al 1986, OEPA 1989) and is responsive to environmental degradation from a variety of causes. An important compliment to IBI monitoring is the use of Qualitative Habitat Evaluation Procedures (QHEI) (Rankin 1989, IDEM 2006) as habitat quality can have significant influences on fish community health. In addition to agency water quality monitoring programs, IBI studies are often implemented on gradients of various types of stressors such as: QHEI degradation gradient (Goldstein and Meador 2005), hydro-electric power disturbance gradient (Kinsolving and Bain 1993), land use gradient (Lydy et al. 2000, Schleiger 2000), urbanization (Fitzpatrick et al. 2004, Matzen and Berge 2008) in-stream 
habitat gradients (Schlosser 1982, Crail et al. 2011), forest canopy gradient (inversely correlated to sedimentation) (Sutherland et al. 2002), and temporal gradients (Meffe and Berra 1988, Matthews et al. 1992, Stainbrook et al. 2006, Johnson and Maceina 2009). Biological surveys can be effective in identifying impaired stream reaches, but such simple models of single or even multiple stressors are inadequate to confirm true cause effect relationships (Novotony et al. 2005). Data collected on spatial or temporal gradients can generate evidence for and against causation (see Table 1 of Suter et al. 2002), however they are not capable of inferring causation of impairment without appropriate analysis of additional data (Suter et al. 2002). This additional analysis involves developing associations among chemical and biological measurements, field experiments regarding exposure, and lab studies. Identification of stressors is often a process fraught with the possibilities for Type I and Type II errors (Morris et al. 2006) but it is a necessary step toward protecting and/or restoring biological resources (U.S. EPA 2000). By developing improved regional classification (based on ecoregion and zoogeographical considerations), and the addition of many small streams, Southerland et al. (2007) improved the ability of Maryland's IBI to have high classification efficiencies and improved balance between Type I and Type II errors.

Patterns in biological assemblage structure and function associated with environmental contaminant field studies are generally lacking (Simon 2003). A few studies have compared organism- and community-level responses at discharges (Kovacs et al. 2002, Porter and Janz 2003), or contaminated waterways (Bervoets et al. 2005, Hartwell 1997) or both (Mayon et al. 2006). Pulp and paper mill effluents have been examined using $\mid \mathrm{BI}$ and fish health assessment indices (HAI); only IBI scores improved 
with improvements to effluent quality (Kovacs et al. 2002). The index of biotic integrity proved to be suitable for the assessment of a pronounced metal pollution gradient $(\mathrm{Cd}$ and $\mathrm{Zn}$ ) when compared with toxic unit (TU) values for water and TUs in fish livers (Bervoets et al. 2005). Water column and sediment toxicity from metals and polycyclic aromatic hydrocarbons (PAHs) do correlate well with IBI scores, however closer associations can be observed between risk scores and specific component metrics (Hartwell 1997). Mayon et al. (2006) studied individual fish HAI and community IBI scores from reference sites and compared them to streams receiving bleach kraft mill effluents (BKME), streams with elevated agricultural pesticide inputs, and streams contaminated with polychlorinated biphenyls (PCBs). Fish communities at the BKME and pesticide streams had unbalanced populations with few juveniles. There were no males present at the BKME site, and feminized males at the pesticide site. The PCB contaminated site had the highest IBI score of the study, high reproductive variability, and a disrupted population containing almost exclusively juveniles. All three sites (BKME, pesticides and PCBs) had increased levels of atresia in reproductive females. Although PCBs have been shown to impair female fish survivorship (Black et al. 1998a) and reproduction (Black et al. 1998b, Khan et al. 2001), we have found no other studies that evaluate fish assemblages attributes in fish communities that have been exposed to reproductive limiting PCBs. Since the early 1980s, the State of Indiana has placed Clear Creek and Conards Branch/Richland Creek on its Clean Water Act §303(d) list of impaired waterways due to the significant levels of PCBs that have contaminated these streams from Lemon Lane Landfill (LL) (http://cfpub.epa.gov/supercpad/SiteProfiles/index.cfm?fuseaction= second.Contams\&id=0501812) and Neal's Landfill (NL) (http://cfpub.epa.gov/supercpad/ 
cursites/csitinfo.cfm?id=0501759) National Priorities List (Superfund) sites. These streams have been studied intensively by State and Federal agencies and Potentially Responsible Parties (PRPs) (Russell et al. 2006) and regulatory determinations have been made that PCBs are the contaminant of concern. Tens of millions of dollars have been spent investigating and taking remedial actions due to PCB contamination in these streams and source areas over the past 30 years. Modeled long-term effects of $100 \mathrm{ng} / \mathrm{L}$ (parts per trillion [ppt]) PCBs in water of the Everglades could have adverse affects on survival and reproduction of fish communities (Al-Rabai'ah et al. 2005), while freshwater ecosystems with PCB water concentrations above 1 to $5 \mathrm{ng} / \mathrm{L}$ are considered to be areas of suspected or known contamination sources (Niimi 1996). Water borne concentrations of PCBs were entering our study site streams at several orders of magnitude above this level during the timeframe of our study (Table 1).

Hartwell (1997) predicted that: 1) high IBI scores would only be found where low (acute) toxicity values are observed; 2 ) where high toxicity values were documented, low IBI scores would be observed; and, 3) it is possible that low IBI scores and low toxicity values might be present at some sites, but that other causes would be responsible for reduced IBI scores. This does not answer the question whether chronic toxicity or sublethal reproductive impairments are reflected in IBI scores or not. Reduced growth and survivorship of female creek chub Semotilus atromaculatus (Mitchill) has been reported from PCB-contaminated Clear Creek and Conards Branch / Richland Creek (Henshel et al. 2006). Creek chubs are a prominent species in the fish assemblages at these PCB-contaminated stream reaches and it was hypothesized that PCB-induced impacts observed in this species would be reflected in community IBI scores. Similar to 
the findings of Mayon et al. (2006), we have observed that IBI scores in general do not identify subtle fish community impacts in areas of moderate and low PCB contamination. Following the recommendations of Hartwell (1997) and Suter et al. (2002), we initiate this investigation of fish assemblage patterns by evaluating the component parts (individual metrics) of the IBI along a PCB gradient to assess the relationship (if any) between PCBs and the $\mathrm{IBI}$.

\section{Materials and Methods}

Ecoregion and Site Description

Our four sites located in the West Fork White River drainage, in southcentral Indiana, U.S.A. (Figure 1). In order for biological surveys to be meaningful, it is important to have regional calibrations of IBI models to address variations in zoography or basin (catchment) species distributions (Miller et al.1998, Angermeier et al. 2000, McCormick et al. 2000, Whittier et al. 2007). The regional expectations of the biological integrity of central Indiana (Eastern Corn Belt Plain, ECBP) water resources were developed by Simon and DuFour (1998). Best achievable conditions in the ecoregion are based on the concept of "least impacted" reference conditions for establishing baseline conditions (Hughes 1995, Hughes et al. 1986). This calibration uses an ecological classification that recognizes expected differences in biological assemblages based on potential natural vegetation, soils, land forms, and climate (Omernik 1987). In addition, the ECBP IBI (Simon and Dufour 1998) has been regionally calibrated to accommodate headwater stream conditions. Individual metric response was evaluated by comparing various characteristics or metrics for each site to patterns in the regional expectations 
representative of the region (Karr et al. 1986, Simon and Dufour 1998). Least impacted sites $\left(95^{\text {th }}\right.$ percentile and above) represent the best, current conditions in the ecoregion. Reference conditions of the ECBP represent best achievable conditions for the ecoregion $\mathrm{IBI}$, however the reference site we chose for this analysis was Little Indian Creek, Greene County, Indiana which more closely resembles the PCB-gradient sites in geography, land-use, average QHEI and IBI scores, but without a source of PCB contamination (Table 1).

We chose 3 sites from within the ECBP that represent a relative PCB concentration gradient influenced by LL or NL Superfund sites, Monroe County, Indiana, U.S.A. Fish assemblage data were collected from the Clear Creek watershed from two locations approximately 1400-m and 3100-m downstream [Illinois Central Springs Branch (ICS) and Clear Creek (CC), respectively] of the primary discharge of PCB-contaminated groundwater emanating from LL. Conards Branch (CB) was sampled beginning approximately $800 \mathrm{~m}$ downstream of the primary discharge of PCB-contaminated groundwater emanating from NL.

Over the life of the Superfund program involvement at these sites, thousands of fish tissue, water, and sediment samples have been collected from these study sites and chemically analyzed for hazardous substances and the overriding contaminant of concern has been established to be PCBs (U.S. EPA 2012a, 2012b). The ambient water quality criteria for the protection of freshwater aquatic life from acute effects is $0.014 \mu \mathrm{g} / \mathrm{L}$ (14 ppt) (U.S. EPA 2012c). During the timeframe which this investigation was conducted, PCBs were entering these streams anywhere from $100-470,000$ ppt. Table 1 briefly summarizes the relative PCB contamination of the various media (e.g. groundwater at the 
source spring; ambient surface water, sediment and whole creek chubs at the sites) impacting these sample locations during the timeframe in which our fish assemblage data were collected. These data reflect the relative gradient of PCB exposures to the fish assemblages at CC (low), CB (medium), and ICS (high) that these sites have been enduring for more than 2 decades. Only very low concentrations of PCBs are found in fish at $\mathrm{LI}$ (reference) (Table 1) confirming that it is suitable to represent background conditions for southcentral Indiana.

Finally, all of these sites were chosen in such a way as to exclude other confounding point source discharges upstream of these selected sites. Habitat characteristics were evaluated using QHEI (Ohio Environmental Protection Agency 1989; Rankin 1995) (Table 1).

\section{Design and Field Collection}

Collections of fish assemblages were conducted at the four sites between the months of June and September in 1995, and 1999-2002. Complete fish assemblage data were available for LI ( $n=14), C C(n=11), C B(n=9)$, and ICS ( $n=8)$. Collections were made during daylight hours using a back-pack pulsed-DC electrofishing unit (model ABP-3450V, ETS Electrofishing LLC, Verona, WI) capable of 2-3 A output following a standard operating procedure (Simon 1991). Fish were collected from within a stream reach equal

to $15 \mathrm{x}$ the mean stream wetted width, for a minimum collection distance equal to $50 \mathrm{~m}$. All fish encountered within the electrofishing reach were netted and placed into a live well until the conclusion of the sampling zone. All fish were identified to species, enumerated, and measured for minimum and maximum length ( $\mathrm{mm} \mathrm{TL}$ ), batch weighed (nearest $1 \mathrm{~g}$ ), 
and inspected for deformities, eroded fins, lesions, and tumors (DELT) anomalies (Sanders et al. 1999). Large fish specimens were released, while small species (e.g., minnows, darters, and madtoms) were preserved in $10 \%$ formalin for later laboratory identification using regional references (Gerking 1955, Smith 1979, Trautman 1981).

\section{Structure and Function Guild Classification}

We assigned fish species to 51 structure and function characteristics based on species composition and relative abundance, biomass, and a multimetric index of biological integrity (Table 2). Fish collected during this study were classified based on species composition (Simon et al. 2002), habitat specialization (Simon 1991), functional guild assignments including trophic (Goldstein and Simon 1999), reproductive (Simon 1999), tolerance attributes (Simon 1991), and pioneer species (Smith 1971) (Table 3).

\section{Data Analysis and Statistics}

We evaluated PCB effects on fish assemblage structure by treating each of the four PCBcontaminated streams classes (reference, low, medium and high) as independent PCB treatments and testing for relative PCB concentration effect using the Kruskal-Wallis ANOVA by Ranks test. This test assumes that the variables are both continuous and/or measured on an ordinal scale and that samples being compared were drawn from the same distribution or distributions having the same median. Thus, the interpretation of the Kruskal-Wallis test is virtually identical to that of the one-way ANOVA, except that it is based on ranks rather than means (Siegel and Castellan 1988). Significant results were further scrutinized to minimize any Type I errors. As previously stated, total IBI scores do 
not appear to be responsive to PCB contamination (Mayon et al. 2006, this data set). Because it is our intent to assess the relationship between PCBs and IBI at the individual metric level, variables eliciting a significant non-predictable interaction, i.e., interactions were driven by a significant deviation in treatment that could not be attributed to a PCB dose response pattern, were eliminated from further consideration. All statistical analyses were done using Statistica (StatSoft, Tulsa, OK, U.S.A.). Specific attributes of fish assemblage structure (e.g., composition and relative abundance attributes) and function (e.g., trophic, reproductive, and tolerance guilds) were tested against a PCB gradient. Statistical significance was set at $\alpha<0.05$.

\section{Graphical presentation}

Variables showing significant dose response predictable interactions with increasing PCB gradient were examined further using central tendency. This data was presented using box and whisker plots. Central tendencies of treatment mean structure of statistically significant parameters in the box and whisker data presentation demonstrate the significance of relationships identified by the Kruskal-Wallis ANOVA by Ranks test.

\section{Results}

Thirty-eight fish species representing nine families were collected in the West Fork White River watershed. Collections were numerically dominated by tolerant minnow species, e.g., creek chub, central stoneroller (Campostoma anomalum), and bluntnose minnow (Pimephales notatus), while biomass was dominated by creek chub, central stoneroller, 
and green sunfish (Lepomis cyanellus). QHEl scores ranged from 40.6 to 58.4 (averaging $47.8 \pm 8.6$ ) representative of fair habitat conditions that is able to support fish assemblages (Table 1). Both the ICS and CC sites had high percent sand, with decreasing amounts of gravel, cobble, and boulder. Substrates at CB included nearly equivalent amounts of bedrock, gravel, cobble, and silt. The control site (LI) had dominant substrate type of cobble, followed by reduced levels of gravel, bedrock, sand and boulder. (Table 1). Study sites scored between 27 - 48 IBI points, which would indicate that these sites rank as "fair" to "poor" (Karr et al. 1981) (Table 1).

\section{Species composition patterns}

Kruskal-Wallis ANOVA by Ranks Test show that significant differences were observed between eight fish assemblage attributes based on species composition, functional guild characteristics, and relative abundance (Fig. 2). Seven species composition and relative abundance characters declined with increasing PCB concentration including, number of species (NUMSPP), number of darter, madtom and sculpin (NUMDMS); number of darter (NUMD), number of sunfish (NUMSUN), number of sucker (NUMSUC), number of sensitive species (NUMSEN) and percent individuals as carnivores (PERCARN). The percent individuals as pioneer species (PERPIO) was the only characteristic that increased with increasing PCB concentration (Table 4).

\section{Biomass pattern}

Kruskal-Wallis ANOVA by Ranks tests show that significant differences were observed between eleven fish assemblage biomass attributes and PCB treatment (Fig. 3). Eight 
biomass attributes of fish assemblages declined with increasing PCB concentration including the number of species biomass (BIOSPP), number of sunfish biomass (BIOSUN), percent sunfish biomass (PBIOSUN), number of sucker biomass (BIOSUC), percent sucker biomass (PBIOSUC), biomass of sensitive species (BIOSEN), percent sensitive species biomass (PBIOSEN) and percent carnivore biomass (PBIOCARN) (Table 4). Three biomass attributes increased with PCB concentration including percent minnow biomass (PBIOMIN), percent pioneer species biomass (PBIOPIO), and percent tolerant species biomass (PBIOTOL) (Table 4).

IBI metric score patterns

Five IBI metrics of the regionally calibrated index for the Eastern Corn Belt Plain showed a significant difference with PCB concentration using the Kruskal-Wallis ANOVA by Ranks test (Fig. 4). Two IBI metrics, percent individuals as headwater species (MPERHW) and number of minnow species (M-NUMMIN) increased as PCB concentrations increased, while number of sucker species (M-NUMSUC) and percent individuals as pioneer species (M-PERPIO) declined with increasing PCB concentration class (Table 4).

\section{Discussion}

Concentrations of PCBs in water greater than $1 \mu \mathrm{g} / \mathrm{L}(1,000 \mathrm{ppt})$ over a period of weeks to months are lethal to minnows (DeFoe et al. 1978; Nebeker et al. 1974). Our high (ICS) and medium (CB) PCB sites exceeded or approached, respectively these water concentrations in the early 1990s (Table 1). Based on Hartwell's (1997) predictions that 
acute toxicity results in lower IBI scores, it is possible that IBI investigations of these sites in the 1980s would have produced much lower IBI scores than this study. What this hypothetical suggests is that some recovery possibly has already occurred at these sites, at least from an IBI perspective. The issue is that the multimetric IBI score is not responsive to subtle reproductive affects of PCBs (Mayon et al. 2006) and certain specific metrics are more sensitive and informative (Hartwell 1997, Suter et al. 2002, Rashleigh et al. 2004). Our field assessment of fish assemblages did show significant changes in the species composition and relative abundance, biomass, and relationships of these assemblages on an increased PCB gradient. The concept behind the development of ecoregion expectations would suggest that fish structure for these four sites, consisting of similar geography, land-use, average QHEI and IBI scores, should not have been expected to vary or negatively correlate to PCB contamination levels (Karr et al. 1986, Simon and Dufour 1998). Several authors suggest that habitat (QHEI) is the primary parameter to correlate with IBI scores (Goldstein 2009, Lau et al. 2006, Talmage et al. 2002) or a specific habitat metric such as substrate quality (Lydy et al. 2000 , Sutherland et al. 2002). In our particular study, neither IBI scores nor QHEI scores were significantly different, so we would suggest that PCBs may be significant at a local scale (Levin 1992). Perhaps the most pronounced relationships between fish assemblage structure and function were observed in the relationships between the PERCARN, PBIOCARN, and PBIOMIN, PBIOPIO, and the M-NUMMIN. The decline of carnivores at increasing PCB concentrations inversely correlated with the increase of minnow biomass metric scores. Since there were fewer large fish at these sites, including older individuals, the minnow and pioneer species biomass increased dramatically. Predation is an important 
factor in fish communities (Jackson et al. 2001). It is possible that carnivorous fish may be limited in the PCB contaminated sites due to physical constraints in these smaller streams, but grass pickerel have been captured at CB (medium PCBs) (Table 3), and several predator species are present in lower Clear Creek. In regard to headwater streams, variation in reproductive success is more important to community organization than competition or predation (Schlosser 1982). It has also been suggested that droughts or repeated sampling by investigators or consultants working on the remedial investigations of these sites may have continually removed the largest fish such that biomass metrics could have been adversely impacted (Westinghouse, unpublished data). Many IBI studies assess fish communities repeatedly over seasons and years (temporal gradients) (Matthews et al. 1992, Stainbrook et al. 2006) with no ill effects to fish communities. Creek chubs are a significant component of the assemblages at our study sites, and although large creek chubs were present, older female age classes were missing (Henshel et al. 2006). Creek chub growth is sexually dimorphic above two years of age, and older males grow considerably larger than females (Henshel et al. 2006). It is suggested that IBI investigations span at least one generation which for most fish in these streams is 3 to 5 years (Matthews et al. 1988). Midwestern stream faunas tend to be stable (Meffe and Berra 1988); assemblages can be reestablished rapidly and are resistant to, or resilient following drought with little or no change over time (Matthews et al. 1988). Growth rates would likely increase if fish densities or only the largest fish were reduced significantly (Ricker 1954). We did not observe such patterns in the age structure and growth rates of creek chubs from these sites (Henshel et al. 2006), rather like Black et al. (1998a) we documented reduced survivorship in females. 
Additional characteristics that increased with PCB concentration include the PBIOPIO, PBIOTOL, M-PERHW, and M-NUMMIN. The PBIOPIO and PBIOTOL are attributes that reflect unstable conditions and represent declining environmental quality (Karr et al. 1986). The reductions of NUMSPP, NUMSEN, NUMDMS, NUMD and NUMSUN correlated to the PCB gradient is noteworthy. There is habitat available for sensitive darter species at ICS and CC and yet they are not present. Perhaps habitat is limiting for sunfish, but tolerant and pioneer species dominate at ICS and CC. In addition, the recolonization of these sites by tolerant pioneer species (Smith 1971), those species first to reinvade after disturbance is reduced, clearly have the advantage over darters and other sensitive species. Despite this advantage, no reproduction in creek chubs was observed at these PCB sites (Henshel et al. 2006), which was reflected in the number of biomass attributes negatively affected by PCBs. This is consistent with Mayon et al. (2006) observations that at their PCB contaminated site, reproduction was highly variability, with an unbalanced population containing almost exclusively juveniles. It is unknown at this time how reduced reproductive success in tolerant pioneer species like creek chub relate to the absence of sensitive species, but it is conceivable that different reproductive guilds could be impacted differently.

Finally, the contributions of the IBI as a tool to diagnosis stream biological assemblage patterns did not show a significant result with the PCB-gradient. Fish IBIs are more responsive to stressors that affect fish species differentially rather than if all fish species experience reductions in numbers equally (Trebitz et al. 2003). Because subtle adverse effects may be hard to detect, several authors encourage site assessments be made based on all available data, not just summary indices (Hartwell 1997, Suter et al. 
2002, Trebitz et al. 2003). This suggests that the difficulty in detecting, rather than the absence of sublethal effects, are probably the basis of Niimi's (1996) statement that adverse effects on growth and reproduction which have been documented in laboratory studies were at higher PCB concentrations than observed in natural systems. Since PCBrelated sublethal reproductive effects can be obscured by immigration, IBI will not detect a dramatic decline in environmental condition (Table 1). It was not until we evaluated individual metric response of the components of the IBI that we detected significant relationships (Fig. 2, Fig. 3). Sublethal reproductive effects will require a second level of analysis to evaluate fish assemblage biomass and species composition differences that would not be detected by the IBI. All 4 study sites scored between $35-42$ IBI points, which would be a passing aquatic life condition in Indiana Water Quality Standards, yet the reproductive incapacitation of resident females and disappearance of older individuals

would not have been detected by the IBI. Although the IBI is an important monitoring tool in North America, it has limited diagnostic ability as a single number. The strength of the index is the analysis of the individual metrics.

\section{References}

Al-Rabai'ah H, Koh HL, DeAngelis D, Lee LH (2005) Modeling the long-term effect of PCBs on Everglades fish communities. Wetlands Ecol Manage 13:73-81

Angermeier PL, Smogor RA, Stauffer JR (2000) Regional frameworks and candidate metrics for assessing biotic integrity in Mid-Atlantic highland streams. Trans Am Fish Soc 129:962-981 
Bervoets L, Knaepkens G, Eens M, Blust R (2005) Fish community responses to metal pollution. Environ Poll 138:338-349

Black DE, Gutjahr-Gobell R, Pruell RJ, Bergen B, Mills L, McElroy AE (1998a)

Reproduction and polychlorinated biphenyls in Fundulus heteroclitus (Linnaeus) from New Bedford Harbor, Massachusetts, USA. Environ Toxicol Chem 17:1405-1414

Black DE, Gutjahr-Gobell R, Pruell RJ, Bergen B, Mills L., McElroy AE (1998b) Effects of a mixture of non-ortho- and mono-ortho-polychlorinated biphenyls on reproduction in Fundulus heteroclitus (Linnaeus). Environ Toxicol Chem 17:1396-1404

CBS (1998) Letter regarding preliminary data for sampling performed under Bloomington Project Quality Assurance Project Plan Volume IX, Neal's Landfill stream sampling plan. From Dorthy M. Alke, Project Director, to Distribution List June 29, 1998. Pittsburgh, PA

Crail TD, Gottgens JF, Krause AE (2011) Fish community response to evolving channel complexity in an agricultural headwater system. J Soil Water Conserv 66:295-302

DeFoe DL, Veith GD, Carlson RW (1978) Effects of Arochlor 1248 and 1260 on the fathead minnow (Pimephales promelas). J Fish Res Board Can 35:997-1002

Fitzpatrick FA, Harris MA, Arnold TL, Richards KD (2004) Urbanization influences on 
aquatic communities in northeastern Illinois streams. J Am Water Res Assoc 40:461-475

Gerking SD (1945) Distribution of the fishes of Indiana. Inv Ind Lakes Streams 3:1-137

Goldstein RM (2009) Interpreting stream physical characteristics in index of biotic integrity classifications: general similarities and specific differences. N.Am. J. Fish. Manage. 29:151-162

Goldstein RM, Meador MR (2005) Multilevel assessment of fish species traits to evaluate habitat degradation in streams of the upper Midwest. N Am J Fish Manage 25:180-194

Goldstein RM, Simon TP (1999) Toward a united definition of guild structure for feeding ecology of North American freshwater fishes. In: Simon TP (ed) Assessing the sustainability and biological integrity of water resources using fish communities. CRC, Boca Raton, FL, pp 123-202

Hartwell SI (1997) Demonstration of a toxicological risk ranking method to correlate measures of ambient toxicity and fish community diversity. Environ Toxicol Chem 16:361371

Henshel DS, Sparks DW, Simon TP, Tosick MJ (2006) Age structure and growth of Semotilus atromaculatus (Mitchill) in PCB-contaminated streams. J Fish Biol 68:44-62 
Hughes RM (1995) Defining acceptable biological status by comparing with reference condition, In: Davis WS, Simon TP (eds) Biological assessment and criteria: Tools for water resource planning and decision making. Lewis, Boca Raton, FL. pp 31-47

Hughes RM, Larsen DP, Omernik JM (1986) Regional reference sites: a method for assessing stream potentials. Environ Manage 10:629-635

Indiana Department of Environmental Management (IDEM) (2006) Biological studies section qualitative habitat evaluation index [QHEI] standard operating procedure. Indiana Department of Environmental Management, Indianapolis, IN Available at: (http://monitoringprotocols.pbworks.com/f/IDEM+QHEI+SOP.pdf)

Jackson DA, Peres-Neto PR, Olden JD (2001) What controls who is where in freshwater fish communities - the roles of biotic, abiotic, and spatial factors. Can J Fish Aquat Sci $58: 157-170$

Johnston CE, Maceina MJ (2009) Fish assemblage shifts and species declines in Alabama, USA streams. Ecol Freshwater Fish 18:33-40

Karr JR, Fausch KD, Angermeier PL, Yant PR, Schlosser IJ (1986) Assessing biological integrity in running waters: A method and its rationale. III Nat Hist Surv Spec Pub 5. Champaign, IL, USA 
Khan IA, Matthews S, Okuzawa K, Kagawa H, Thomas P (2001) Alterations in the GnRHLH system in relation to gonadal stage and Aroclor 1254 exposure in Atlantic croaker. Comp Biochem Physiol B 129:251-259

Kinsolving AD, Bain MB (1993) Fish assemblage recovery along a riverine disturbance gradient. Ecol Appl 3:531-544

Kovacs TG, Martel PH, Voss RH (2002) Assessing the biological status of fish in a river receiving pulp and paper mill effluents. Environ Poll 118:123-40

Lau JK, Lauer T, Weinman ML (2006) Impacts of channelization on stream habitats and associated fish assemblages in east central Indiana. Am Midl Nat 156:319-330

Levin, SA (1992) The problem of pattern and scale in ecology. Ecol 73:1943-1967

Lydy MJ, Strong AJ, Simon TP (2000) Development of an Index of biotic integrity for the Little Arkansas River basin, Kansas. Arch Environ Contam Toxicol 39:523-530

Matthews WJ, Hough DJ, Robison HW (1992) Similarities in fish distribution and water quality patterns in streams of Arkansas: congruence of multivariate analyses. Copeia 1992:296-305

Matthews, WJ, Cashner RC, Gelwick FP (1988) Stability and persistence of fish faunas 
and assemblages in three midwestern streams. Copeia 1988:945-955

Matzen DA, Berge HB (2008) Assessing small-stream biotic integrity using fish assemblages across an urban landscape in the Puget Sound lowlands of western Washington. Trans Am Fish Soc 137:677-689

Mayon N, Bertrand A, Leroy D, Malbrouck C, Mandiki SNM, Silvestre F, Goffart A, Thome J-P, Kestermont P (2006) Multiscale approach of fish responses to different types of environmental contaminations: a case study. Sci Total Environ 367:715-731

McCormick FH, Peck DV, Larsen DP (2000) Comparison of geographic classification schemes for Mid-Atlantic stream assemblages. J N Am Benthol Soc 19:385-404

Meffe GK, Berra TM (1988) Temporal characteristics of fish assemblage structure in an Ohio Stream. Copeia 1988:684-690

Miller DL, Leonard PM, Hughes RM, Karr JR, Moyle PB, Schrader LH, Thompson BA, Daniels RA, Fausch KD, Fizthugh GA, Gammon JR, Halliwell DB, Angermeier PL Orth DJ (1998) Regional applications of an index of biotic integrity for use in water resource management. Fisheries 15(5):12-20

Morris CC, Simon TP, Newhouse SA (2006) A local-scale In Situ approach for stressor identification of biologically impaired aquatic systems. Arch Environ Contam Toxicol 
$50: 325-334$

Nebeker AV, Puglisi FA, DeFoe DL (1974) Effect of polychlorinated biphenyl compounds on survival and reproduction of the fathead minnow and flagfish. Trans Am Fish Soc 103:562-568

Niimi AJ (1996) PCBs in aquatic organisms. In: Beyer WN, Heinz GH, Redmon-Norwood AW, (eds) Environmental contaminants in wildlife: Interpreting tissue concentrations. Lewis, Boca Raton, FL, pp 117-163

Normandeau (1995) Ecological Assessment of Illinois Central/Quarry Springs System and Clear Creek 1994. Normandeau Associates, Spring City, PA

Novotny V, Bartosova A, O'Reilly N, Ehlinger T (2005) Unlocking the relationship of biotic integrity of impaired waters to anthropogenic stresses. Water Res 39:184-198

Omernik JM (1987) Ecoregions of the conterminous Unites States. Ann Assoc Am Geog $77: 118-125$

Porter CM, Janz DM (2003) Treated municipal sewage discharge affects multiple levels of biological organization in fish. Ecotoxicol Environ Saf 54:199-206

Ohio Environmental Protection Agency (OEPA) (1989) Biological criteria for the protection 
of aquatic life: Volume III: Standardized biological field sampling and laboratory methods for assessing fish and macroinvertebrate communities. Ohio Environmental Protection Agency, Division of Water Quality, Monitoring and Assessment, Columbus, $\mathrm{OH}$

Rankin ET (1989) The qualitative habitat evaluation index [QHEI], rationale, methods and application. Ecological Assessment Section, Ohio Environmental Protection Agency, Columbus, $\mathrm{OH}$

Rankin ET (1995) The use of habitat assessments in water resource management programs. In: Davis WS, Simon TP (eds) Biological assessment and criteria: tools for water resource planning and decision making. CRC, Boca Raton, FL, pp 181-208

Rashleigh B (2004) Relation of environmental characteristics to fish assemblages in the upper French Broad River basin, North Carolina. Environ Monit Assess 93:139-156

Ricker WE (1954) Stock and recruitment. J Fish Res Board Can 11:559-623

Russell KT, Rhea JR, Ku W, Glaser D, Cepko RP (2006) Use of mathematical models to evaluated management options for reducing PCB bioaccumulation by fish in two streams at the Neal's landfill site, Bloomington, IN. Proc Water Environ Found 2006:3875-3889

Sanders RE, Miltner RJ, Yoder CO, Rankin ET (1999) The use of external deformities, erosion, lesions, and tumors (DELT anomalies) in fish assemblages for characterizing 
aquatic resources: a case study of seven Ohio streams. In: Simon TP (ed), Assessing the sustainability and biological integrity of water resources using fish communities. CRC, Boca Raton, FL, pp 225-246

Schleiger SL (2000) Use of an index biotic integrity to detect effects of land uses on stream fish communities in west-central Georgia. Trans Am Fish Soc 129:1118-1133

Schlosser IJ (1982) Fish community structure and function along two habitat gradients in a headwater stream. Ecol Mon 52:395-414

Siegel S, Castellan Jr. NJ (1988) Nonparametric statistics for the behavioral sciences. McGraw-Hill, New York

Simon TP (1991) Development of Ecoregion Expectations for the Index of Biotic Integrity. I. Central Corn Belt Plain. EPA 905-9-91-025. United States Environmental Protection Agency, Environmental Sciences Division, Chicago, IL

Simon TP (1999) Assessment of Balon's reproductive guilds with application to Midwestern North American freshwater fishes. In: Simon TP (ed) Assessing the sustainability and biological integrity of water resources using fish communities. CRC Boca Raton, FL, pp 97-122

Simon TP (2003) Biological response signatures: Indicator patterns using aquatic 
communities. CRC, Boca Raton, FL

Simon TP, Dufour RL (1998) Development of index of biotic integrity expectations for the ecoregions of Indiana. V. Eastern Corn Belt Plain. EPA 905/R-96/002. United States Environmental Protection Agency, Region V. Water Division, Watershed and Nonpoint Source Branch, Chicago, IL

Simon TP, Whitaker JO Jr, Castrale JS, Minton SA (2002) Revised checklist of the vertebrates of Indiana. Proc Ind Acad Sci 111:182-214

Smith PW (1979) The fishes of Illinois. University of Illinois Press, Champaign, IL

Smith PW (1971) Illinois streams: A classification based on their fishes and an analysis of factors responsible for disappearance of native species. III Nat Hist Surv Biol Notes 76, Champaign, IL

Southerland MT, Rogers GM, Cline MJ, Morgan RP, Boward DM, Kazyak PF, Klauda RJ, Stranko SA (2007) improving biological indicators to better assess the condition of streams. Ecol Indicators 7:751-767

Stainbrook KM, Limburg KE, Daniels RA, Schmidt RE (2006) Long-term changes in ecosystem health of two Hudson valley watersheds, New York, USA, 1936-2001. Hydrobiologia 571:313-327 
Suter GW, Norton SB, Cormier SM (2002) A methodology for inferring the causes of observed impairments in aquatic ecosystems. Environ Toxicol Chem 21:1101-1111

Sutherland AB, Meyer JL, Gardiner EP (2002) Effects of land cover on sediment regime and fish assemblage structure in four southern Appalachian streams. Freshwater Bio 47:1791-1805

Talmage PJ, Perry JA, Goldstein RM (2002) Relation of instream habitat and physical conditions to fish communities of agricultural streams in the northern Midwest. N Am J Fish Manage 22:825-833

Tetra Tech (2000) Revised Current Status Report for Groundwater, Surface Water, Sediment and Fish Data: Neal"s Landfill Site, Monroe County, Indiana. Tetra Tech EM Inc, Chicago, IL

Tetra Tech (2001) Draft Current Status Report for Groundwater, Surface Water, Soil, Sediment and Fish Data: Lemon Lane Landfill Site, Monroe County, Indiana. Tetra Tech EM Inc, Chicago, IL

Trebitz AS, Hill BH, McCormick FH (2003) Sensitivity of indices of biotic integrity to simulated fish assemblage changes. Environ Manage 32:499-515

Trautman MB (1981) The fishes of Ohio. Ohio State University Press, Columbus, $\mathrm{OH}$ 
U.S. Environmental Protection Agency (U.S. EPA) (1992) Ecological Assessment Report for ICS/Quarry Springs Complex, Lemon Lane Landfill, Bloomington, Indiana.: U.S. Environmental Protection Agency, Office of Superfund. Chicago, IL

U.S. EPA (2000) Stressor identification guidance document. EPA/822/B-00/025. Washington, DC

U.S. EPA (2012a) Contaminants of Concern at Neal's Landfill (Bloomington) (EPA ID: IND980614556). Accessed November 1, 2012 at: http://cfpub.epa.gov/supercpad/ SiteProfiles/index.cfm?fuseaction=second.Contams\&id=0501759

U.S. EPA (2012b) Contaminants of Concern at Lemon Lane Landfill (Bloomington) (EPA ID: IND980794341). Accessed November 1, 2012 at: http://cfpub.epa.gov/supercpad $\underline{\text { SiteProfiles/index.cfm?fuseaction=second. Contams\&id=0501812 }}$

U.S. EPA (2012c) PCB ambient water quality criteria. Accessed November 1, 2012 at: http://water.epa.gov/scitech/swguidance/standards/criteria/current/index.cfm

Westinghouse Electric Corporation (1997) Final Data Transmittal for Ecological/Human Health Risk Assessment Samples Taken in November 1996, under the October 1996 Field Sampling Plan to the Ecological Risk Assessment of the Lemon Lane Landfill IC/QS site. From Dorothy M. Alke, Project Director, to Distribution List. May 19, 1997. Westinghouse Electric Corporation, Pittsburgh, PA 
Whittier TR, Stoddard JL, Larsen DP, Herlihy AT (2007) Selecting reference sites for stream biological assessments: best professional judgement or objective criteria. J N Am Benthol Soc 26:349-360 
Fig. 1. Location of the study sites in the White River drainage, including: upper and lower Clear Creek (ICS and CC), Conards Branch / Richland Creek (CB) and reference site Little Indian Creek (LI), Indiana. 


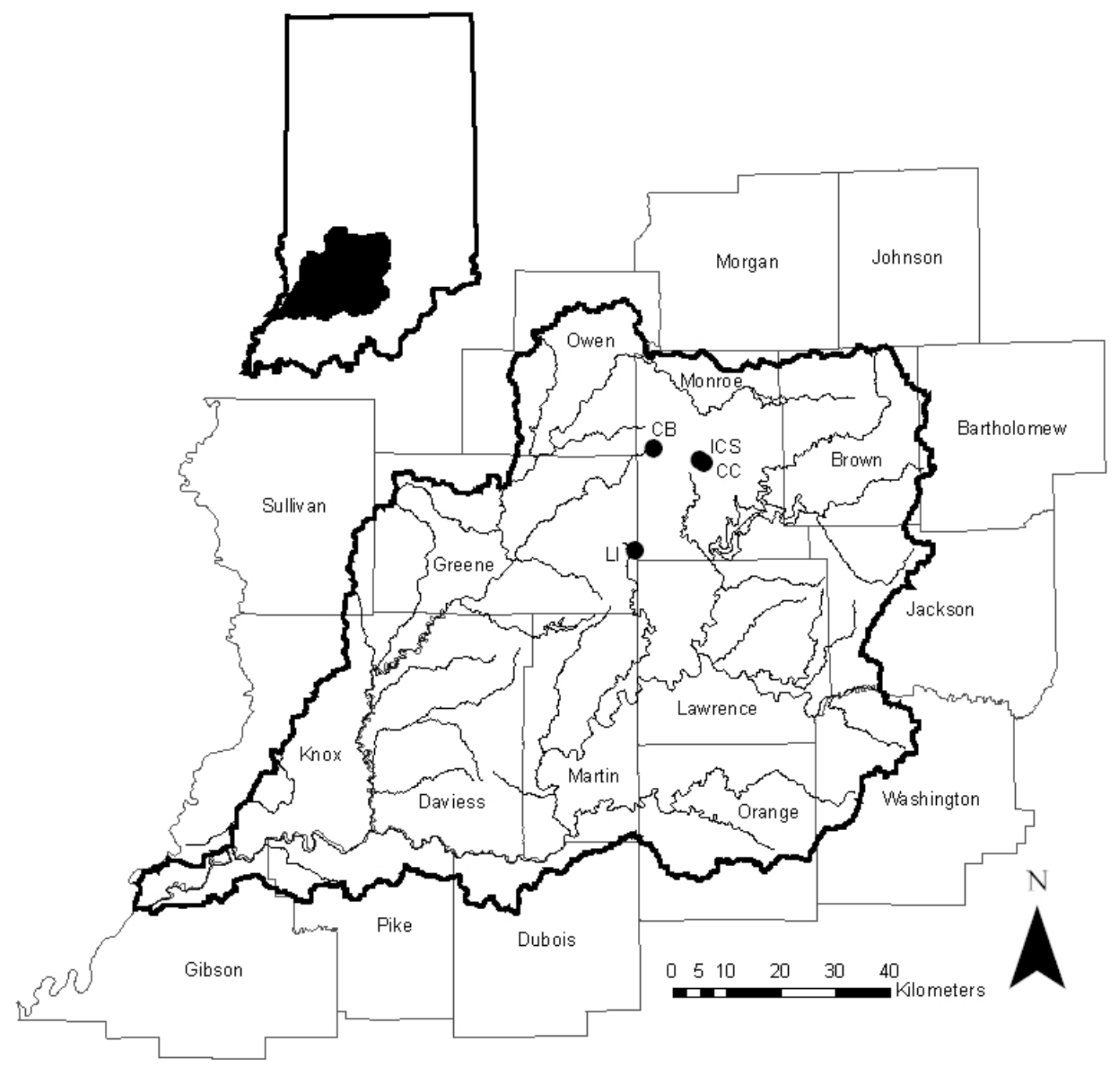


Figure 2. Significant species composition and relative abundance characteristics of fish assemblage structure along a gradient of PCB-contaminated sites: a) total number of species, b) number of darter, madtom and sculpin (DMS) species, c) number of darter species, d) number of sunfish species, e) number of sucker species, f) number of sensitive species, g) percent individuals as pioneer species and $h$ ) percent individuals as carnivore species. 

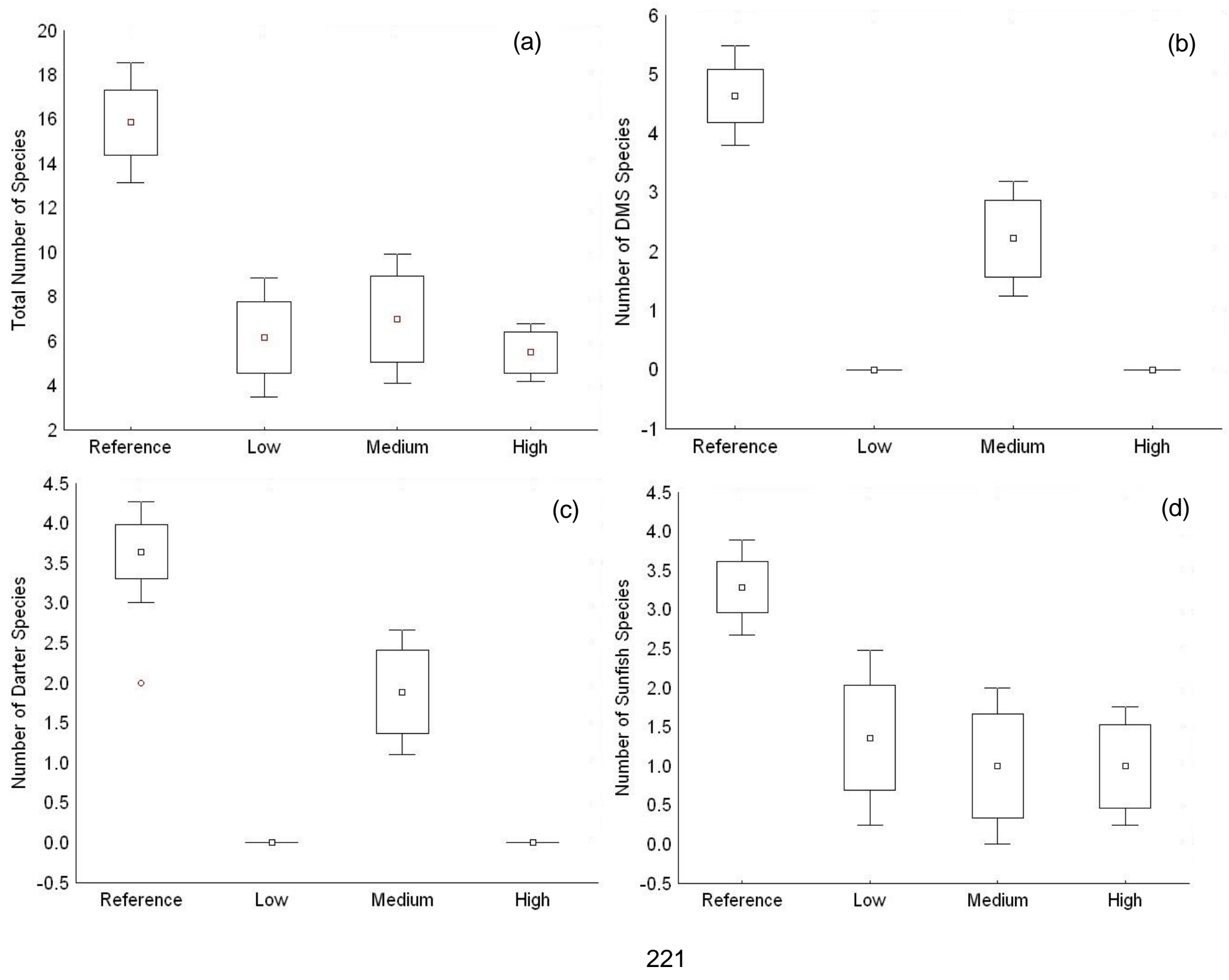

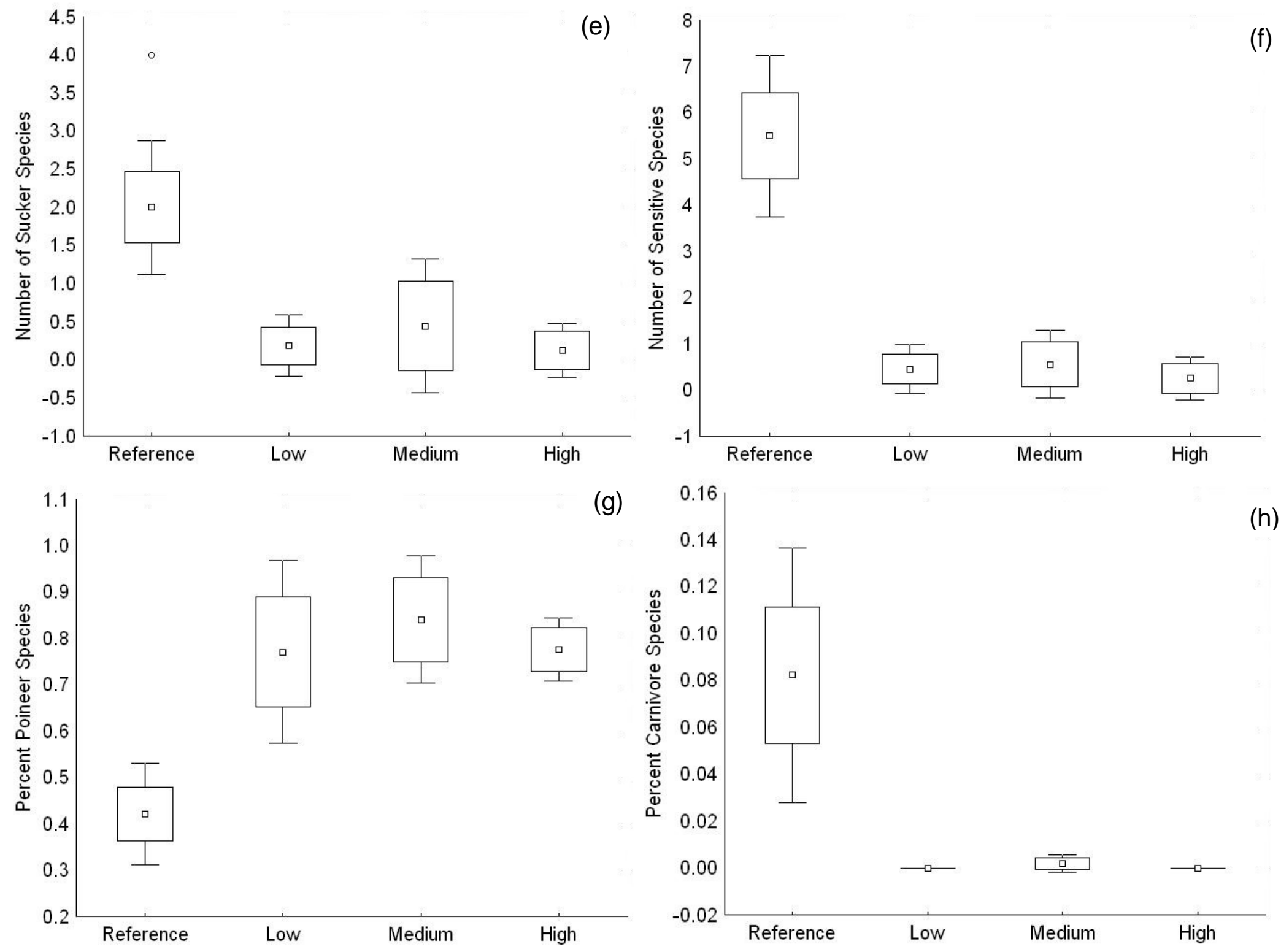
Figure 3. Significant relative biomass characteristics of fish assemblage structure along a gradient of PCB-contaminated sites: a) total biomass of species, b) biomass of sunfish species, c) percent biomass of sunfish species, d) percent biomass of minnow species, e) biomass of sucker species, f) percent biomass of sucker species, g) biomass of sensitive species, h) percent biomass of sensitive species, i) percent biomass of tolerant species, j) percent biomass of pioneer species and k) percent biomass carnivore species. 

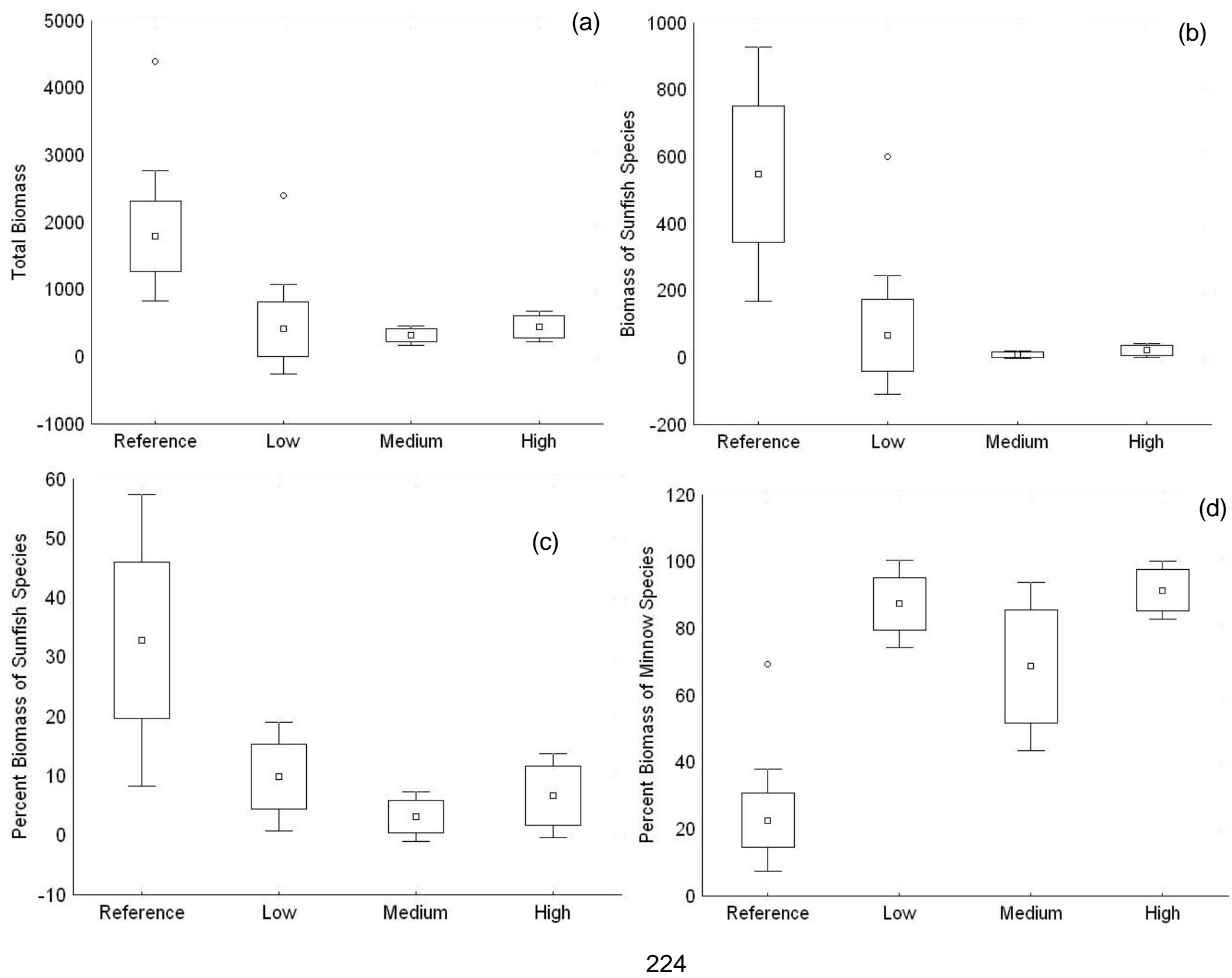

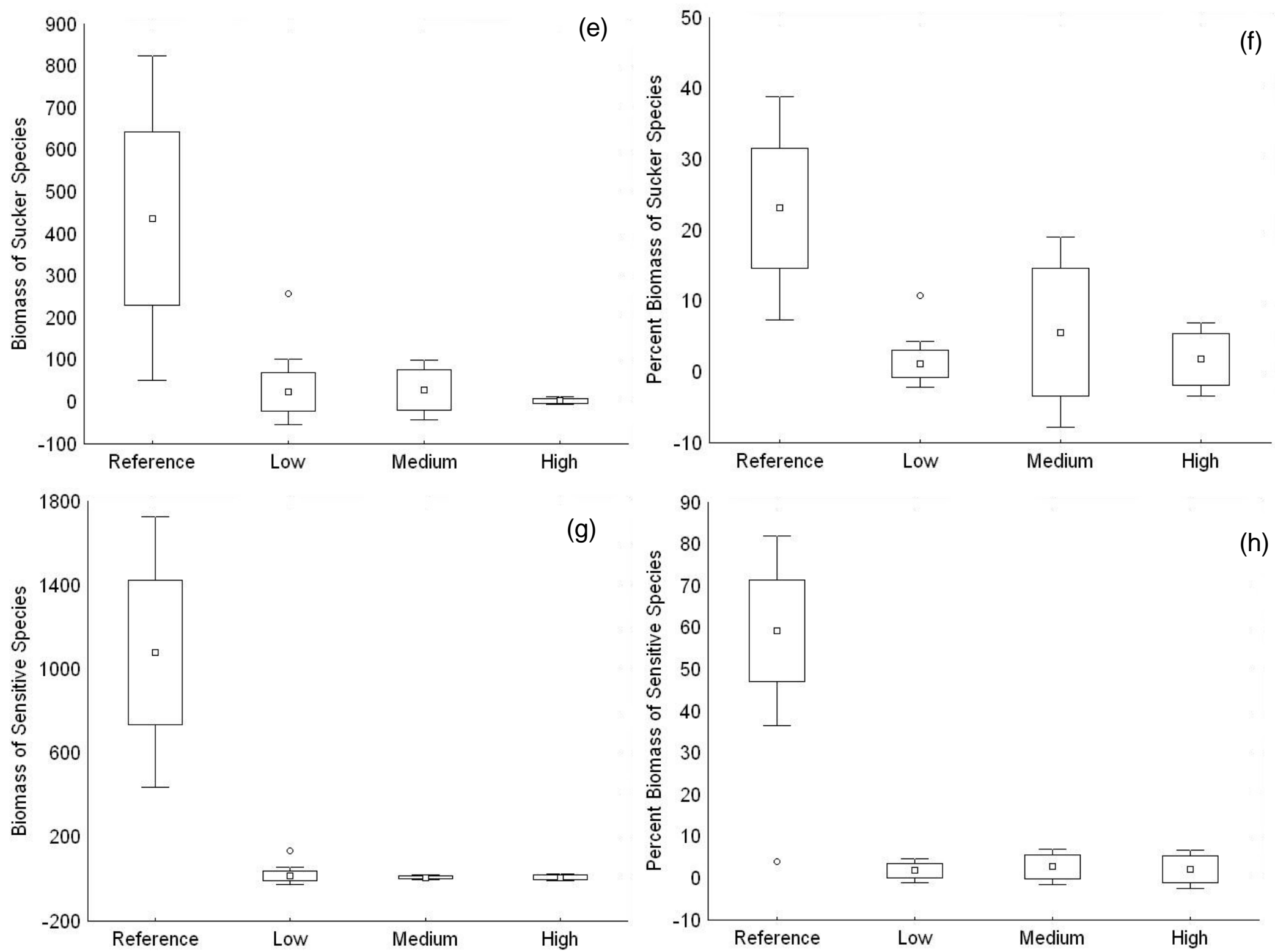
(i)
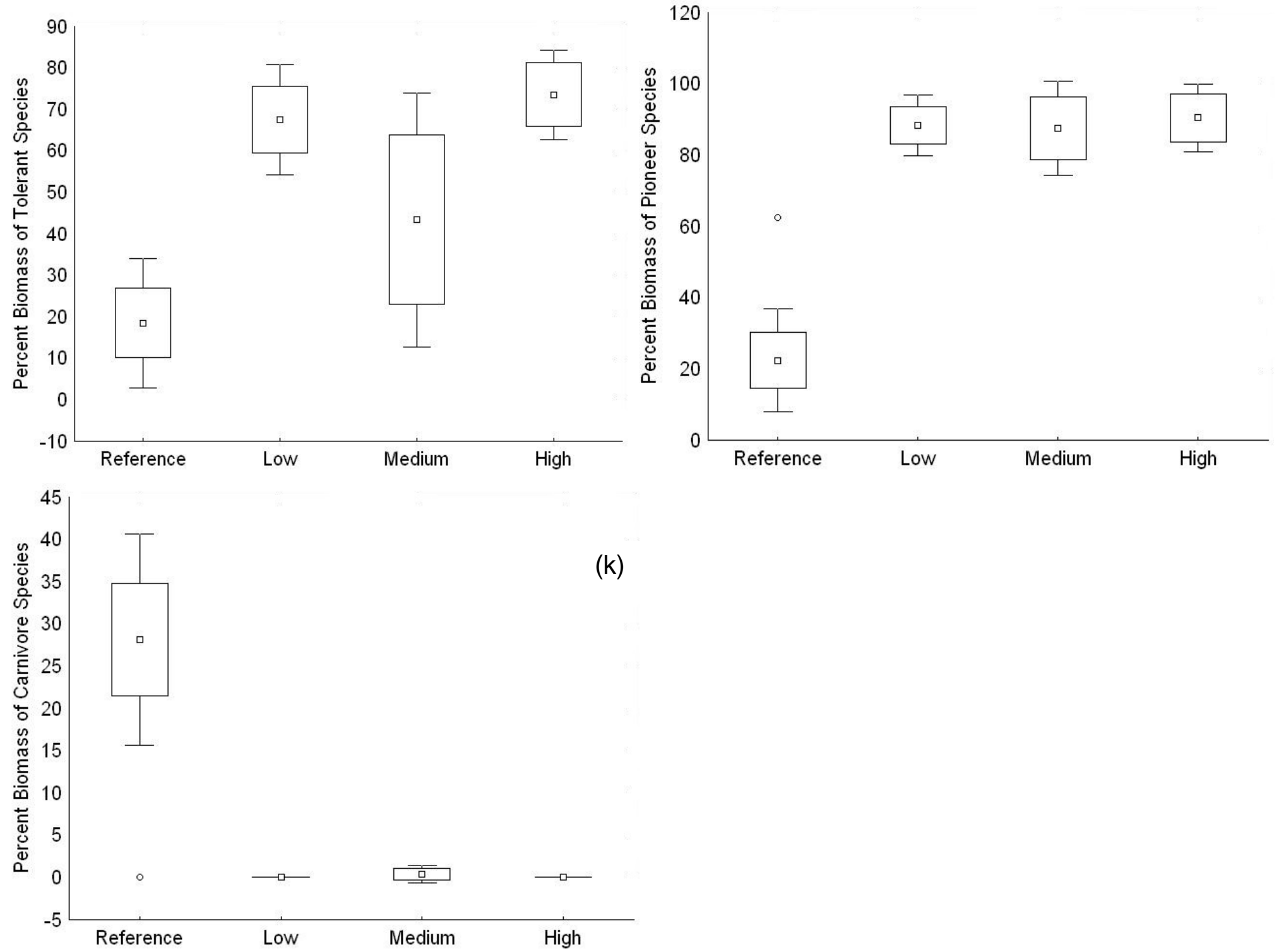
Figure 4. Significance of regionally calibrated Index of Biotic Integrity (IBI) metric scores (Simon and Dufour 1998) at a gradient of PCB-contaminated sites: a) percent individuals as headwater species, b) number of minnow species, c) number of sucker species, d) percent individuals as pioneer species, and e) percent individuals as carnivore species. 

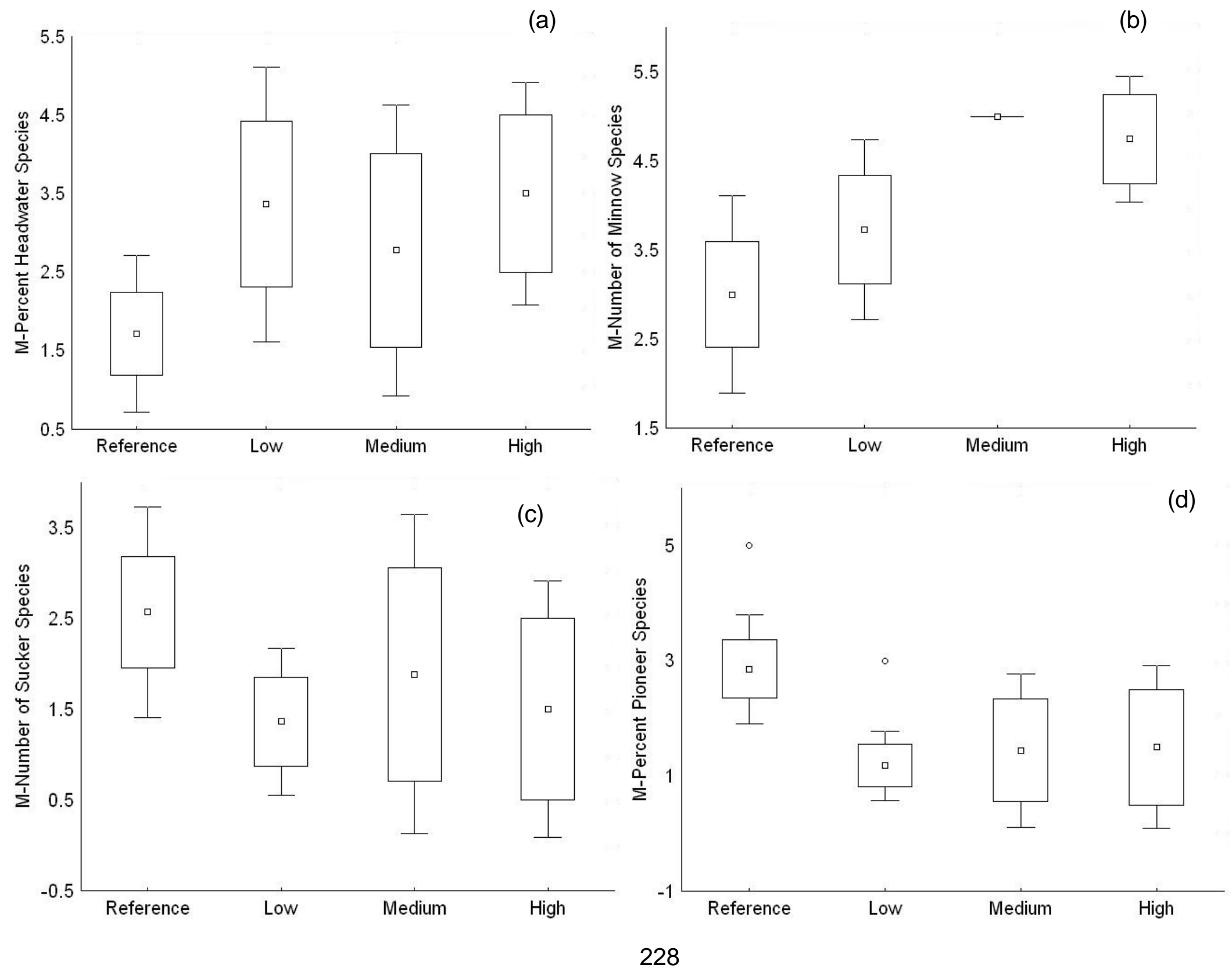
(e)

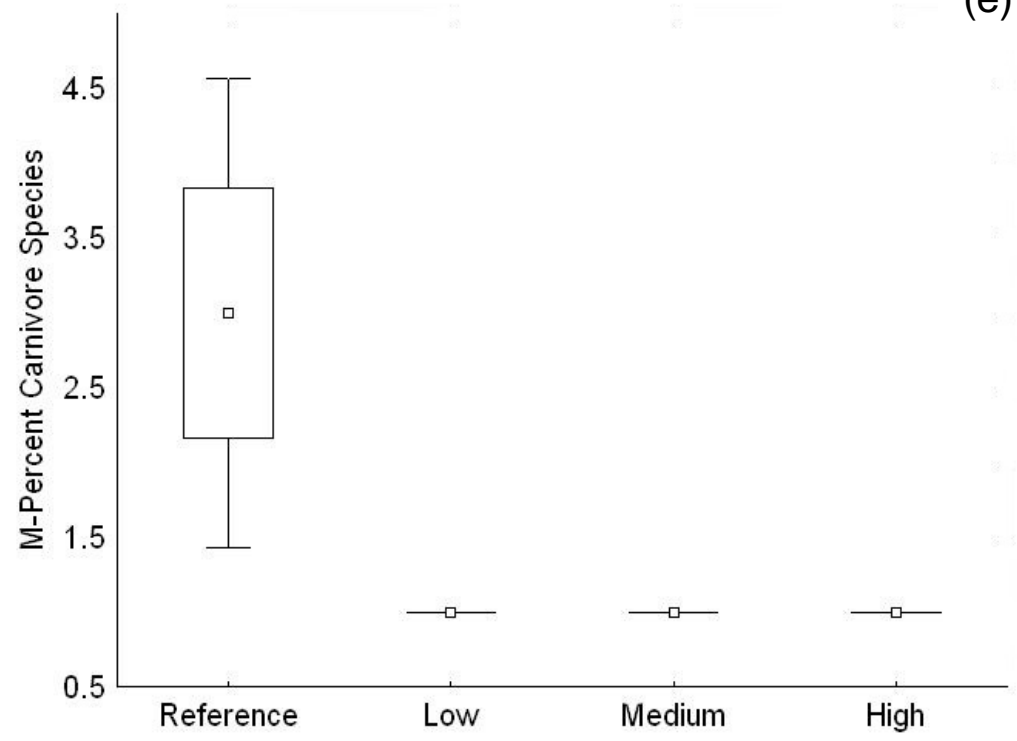


Table 1. Select physical habitat characteristics, habitat quality, biotic integrity and PCB concentrations (range, means $\pm S D$ ) in various media for three PCB contaminated sites and a reference site in the White River drainage, IN, USA.

\begin{tabular}{|c|c|c|c|c|}
\hline & ICS & CB & $\mathrm{CC}$ & $\mathrm{LI}$ \\
\hline \multicolumn{5}{|l|}{ PCB Gradient } \\
\hline Classification & high & medium & low & reference \\
\hline Source of PCBs & Lemon Lane LF & Neals LF & Lemon Lane LF & none known \\
\hline Drainage area $\left(\mathrm{km}^{2}\right.$ & 6.0 & 1.2 & 16.3 & 27.5 \\
\hline $\begin{array}{c}\text { Substrate types } \\
(\%)\end{array}$ & $\begin{array}{l}\text { sand (40), } \\
\text { gravel (35), } \\
\text { cobble (20), } \\
\text { boulder (5) }\end{array}$ & $\begin{array}{l}\text { silt }(25), \\
\text { gravel }(25), \\
\text { cobble }(20), \\
\text { bedrock }(30)\end{array}$ & $\begin{array}{l}\text { sand (35), } \\
\text { gravel (30), } \\
\text { cobble (15), } \\
\text { boulder (15) }\end{array}$ & $\begin{array}{l}\text { sand }(5), \\
\text { gravel }(20), \\
\text { cobble }(60), \\
\text { boulder }(5), \\
\text { bedrock }(10)\end{array}$ \\
\hline Land use & urban/residential & agricultural & urban & agricultural \\
\hline Habitat & forest corridor & $\begin{array}{l}\text { pasture/forested } \\
\text { corridor }\end{array}$ & forested corridor & forested corridor \\
\hline Stream width $(\mathrm{m})$ & 2 & 4 & 3 & 6.5 \\
\hline QHEI & 51.2 & 58.4 & 40.6 & 55.2 \\
\hline Mean IBI & $\begin{array}{l}27.0 \\
\text { Poor }\end{array}$ & $\begin{array}{l}48.5 \\
\text { Good / Fair }\end{array}$ & $\begin{array}{l}34.0 \\
\text { Poor }\end{array}$ & $\begin{array}{l}46.5 \\
\text { Good / Fair }\end{array}$ \\
\hline $\begin{array}{l}\text { PCB groundwater } \\
\text { concentrations at } \\
\text { source }(\mathrm{ppb})\end{array}$ & $\begin{array}{l}4.7-470 \\
\text { (Tetra Tech, 2001) }\end{array}$ & $\begin{array}{l}0.13-8.7 \\
\text { (Tetra Tech, 2000) }\end{array}$ & $\begin{array}{l}4.7-470 \\
\text { (Tetra Tech, 2001) }\end{array}$ & NA \\
\hline $\begin{array}{l}\text { Ambient water at } \\
\text { Study area (ppb) }\end{array}$ & 1.1 (USEPA, 1992) & 0.46 (CBS, 1998) & $\begin{array}{c}<1.0 \text { (USEPA } \\
1992)\end{array}$ & NA \\
\hline Sediments (ppm) & $\begin{array}{l}4.3 \text { (Normandeau, } \\
1995 \text { ) } \\
2.17 \pm 0.26, \mathrm{n}=3 \\
\text { (Westinghouse } 1997\end{array}$ & $\begin{array}{l}1.87 \pm 0.93, n=5 \\
(C B S 1998) \\
7)\end{array}$ & $\begin{array}{l}0.58 \text { (Normandeau, } \\
1995 \text { ) } \\
0.56 \pm 0.14, \mathrm{n}=5 \\
\text { (Westinghouse 1997) }\end{array}$ & NA \\
\hline $\begin{array}{l}\text { Creek Chubs } \\
\text { (whole body, ppm) }\end{array}$ & $\begin{array}{l}19.2 \pm 3.18, n=9 \\
\text { (Westinghouse, } \\
1997 \text { ) }\end{array}$ & $\begin{array}{l}12.1 \pm 3.06, n=8 \\
(C B S, 1998)\end{array}$ & $\begin{array}{c}2.12 \pm 0.18, n=9 \\
\text { (Westinghouse, } \\
\text { 1997) }\end{array}$ & $\begin{array}{c}0.01 \pm 0.002, \mathrm{n}=6 \\
\text { (Henshel et al. } \\
2006)\end{array}$ \\
\hline
\end{tabular}

ICS, upper Clear Creek; CB, Conards Branch/Richland Creek; CC, lower Clear Creek; LI, Little Indian Creek; QHEI, Qualitative Habitat Evaluation Index; IBI, Index of Biotic Integrity; ppb, parts per billion; NA, not analyzed; ppm, parts per million; n, number of samples analyzed. 
Table 2. List of 51 structure and function characteristics of fish assemblages (abbreviations in parentheses) that were tested for significance with PCB gradient.

$\begin{array}{lll}\text { Species Composition } & \text { Biomass } & \text { IBI metric }\end{array}$

Total number species (NUMSPP)

Number darter, madtom, sculpin species (NUMDMS)

Number darter species (NUMD)

Percent headwater species (PERHW)

Number sunfish species (NUMSUN)

Number minnow species (NUMMIN)

Number sucker species (NUMSUC)

Number sensitive species (NUMSEN)

Percent tolerant species (PERTOL)

Percent omnivore species (PEROMN)

Percent insectivore species (PERINS)

Percent pioneer species (PERPIO)

Percent carnivores species (PERCARN)

Number of individuals (CPUE)

Percent lithophilic species (PERLITH)

Percent deformities, eroded fins, lesions, tumors (DELT)
Total biomass species (BIOSPP)

Biomass darter, madtom, sculpin species (BIODMS)

Percent biomass darter, madtom, sculpin

$$
\text { (PBIODMS) }
$$

Biomass darter species (BIOD)

Percent biomass headwater species (PBIOHW)

Biomass sunfish species (BIOSUN)

Percent biomass sunfish species (PBIOSUN)

Biomass minnow species (BIOMIN)

Percent biomass minnow species (PBIOMIN)

Biomass sucker species (BIOSUC)

Percent biomass sucker species (PBIOSUC)

Biomass sensitive species (BIOSEN)

Percent biomass sensitive species (PBIOSEN)

Percent biomass tolerant species (PBIOTOL)

Percent biomass omnivore species (PBIOOMN)

Percent biomass insectivore species (PBIOINS)

Percent biomass pioneer species (PBIOPIO)

Percent biomass carnivore species (PBIOCARN)

Percent biomass simple lithophil (PBIOSLITH)
Total number species (M-NUMSP)

Number darter, madtom, sculpin species (M-NUMDMS)

Number darter species (M-NUMD)

Percent headwater species (M-PERHW)

Number sunfish species (M-NUMSUN)

Number minnow species (M-NUMMIN)

Number sucker species (M-NUMSUC)

Number sensitive species (M-NUMSEN)

Percent tolerant species (M-PERTOL)

Percent omnivore species (M-PEROMN)

Percent insectivore species (M-PERINS)

Percent pioneer species (M-PERPIO)

Percent carnivore species (M-PERCARN)

Number of individuals (M-CPUE)

Percent simple lithophils (M-PERSLITH)

Percent deformities, eroded fins,

lesions, tumors (M-DELT) 
TABLE 3. Fish species collected at the study sites with feeding guild, reproductive guild and tolerance characteristics.

\begin{tabular}{|c|c|c|c|c|c|c|c|c|}
\hline Scientific Name & Common Name & $\mathrm{LI}$ & ICS & CB & $\mathrm{CC}$ & $\begin{array}{l}\text { Feeding } \\
\text { Guild }\end{array}$ & $\begin{array}{l}\text { Repro } \\
\text { Guild }\end{array}$ & Tolerance \\
\hline Esox americanus & Grass Pickerel & $x$ & & $x$ & & $\mathrm{P}$ & M & $P$ \\
\hline Semotilus atromaculatus & Creek Chub & $x$ & $x$ & $x$ & $\mathrm{X}$ & G & $\mathrm{N}$ & $\mathrm{T}$ \\
\hline Rhinichthys obtusus & Western Blacknose Dace & $x$ & $\mathrm{X}$ & $x$ & $\mathrm{X}$ & G & $\mathrm{S}$ & $\mathrm{T}$ \\
\hline Notropis rubellus & Rosyface Shiner & $x$ & & & & I & $\mathrm{S}$ & I \\
\hline Notropis boops & Bigeye Shiner & $\mathrm{x}$ & & & & I & $\mathrm{S}$ & I \\
\hline Ericymba buccata & Silverjaw Minnow & $x$ & & & $x$ & I & $\mathrm{M}$ & - \\
\hline Campostoma anomalum & Central Stoneroller & $x$ & $x$ & $x$ & $x$ & $\mathrm{H}$ & $\mathrm{N}$ & - \\
\hline Pimephales notatus & Bluntnose Minnow & $x$ & $X$ & $X$ & $x$ & $\mathrm{O}$ & $\mathrm{C}$ & $\mathrm{T}$ \\
\hline Chromus eythrogaster & Southern Redbelly Dace & & $X$ & & $x$ & $\mathrm{H}$ & $\mathrm{S}$ & - \\
\hline Cyprinella spiloptera & Spotfin Shiner & $X$ & & & $x$ & I & M & - \\
\hline Luxilus chrysocephalus & Striped Shiner & $x$ & $X$ & $X$ & $x$ & I & $\mathrm{S}$ & - \\
\hline Lythrurus umbratilis & Redfin Shiner & $x$ & & & & I & $\mathrm{N}$ & - \\
\hline Catostomus commersonii & White Sucker & $x$ & $X$ & $X$ & $x$ & $\mathrm{O}$ & $\mathrm{S}$ & $\mathrm{T}$ \\
\hline Erimyzon oblongus & Creek Chubsucker & & & $X$ & & 1 & M & - \\
\hline Moxostoma breviceps & Smallmouth Redhorse & $X$ & & & & I & $\mathrm{S}$ & $M$ \\
\hline Moxostoma duquesnei & Black Redhorse & $x$ & & & & I & $\mathrm{S}$ & $\mathrm{R}$ \\
\hline Moxostoma erythrurum & Golden Redhorse & $x$ & & & & I & $\mathrm{S}$ & $\mathrm{M}$ \\
\hline Hypentilium nigricans & Northern Hogsucker & $x$ & & & & I & $\mathrm{S}$ & $\mathrm{M}$ \\
\hline Noturus miurus & Brindled Madtom & $x$ & & & & i & C & $\mathrm{R}$ \\
\hline Ameiurus melas & Black Bullhead & & & & $x$ & i & C & $\mathrm{T}$ \\
\hline Ameiurus natalis & Yellow Bullhead & $\mathrm{x}$ & & & $x$ & i & C & $\mathrm{P}$ \\
\hline Ameiurus nebulosus & Brown Bullhead & $x$ & & & & i & C & $P$ \\
\hline Fundulus notatus & Blackstripe Topminnow & $\hat{x}$ & & $X$ & & I & $\mathrm{M}$ & - \\
\hline Labidesthes sicculus & Brook Silverside & $\hat{x}$ & & & & I & $\mathrm{M}$ & $M$ \\
\hline Cottus bairdii & Mottled Sculpin & $\hat{x}$ & & $x$ & & I & C & - \\
\hline Cottus carolinae & Banded Sculpin & $x$ & & $x$ & & I & $\mathrm{C}$ & - \\
\hline Ambloplites rupestris & Rock Bass & $x$ & & $x$ & & C & $\mathrm{C}$ & $M$ \\
\hline Lepomis cyanellus & Green Sunfish & $x$ & $x$ & $x$ & $x$ & 1 & $\mathrm{C}$ & $\mathrm{T}$ \\
\hline Lepomis macrochirus & Bluegill & $x$ & & & $x$ & i & C & $\mathrm{P}$ \\
\hline
\end{tabular}


Lepomis megalotis

Micropterus dolomieu

Micropterus salmoides

Micropterus punctulatus

Etheostoma spectabile

\section{Etheostoma nigrum}

Etheostoma blennioides

Etheostoma flabellare

Etheostoma caeruleum

$\begin{array}{ll}\text { Longear Sunfish } & X \\ \text { Smallmouth Bass } & X \\ \text { Largemouth Bass } & X \\ \text { Spotted Bass } & X \\ \text { Orangethroat Darter } & X \\ \text { Johnny Darter } & X \\ \text { Greenside Darter } & X \\ \text { Fantail Darter } & X \\ \text { Rainbow Darter } & X\end{array}$

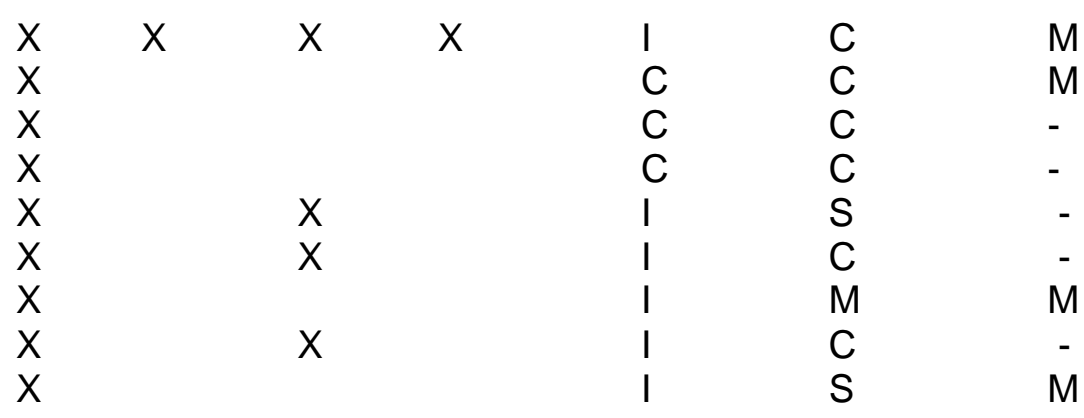

LI, Little Indian Creek; ICS, Illinois Central Springs Branch; CB, Conards Branch Richland Creek; CC, lower Clear Creek. Feeding Guild: $\mathrm{C}=$ carnivore, $\mathrm{G}=$ generalist feeder, $\mathrm{H}=$ herbivore, $\mathrm{I}=$ insectivore, $\mathrm{O}=$ omnivore, $\mathrm{P}=$ piscivore. Reproductive Guild: $\mathrm{C}=$ complex with parental care; $\mathrm{M}=$ simple, miscellaneous; $\mathrm{N}=$ complex, no parental care; $\mathrm{S}=$ simple lithophil. Tolerance/Sensitivity: $\mathrm{I}=$ common intolerant; $M=$ moderately intolerant; $P=$ moderately tolerant; $R=$ rare intolerant; $T=$ highly tolerant; - = tolerance classification undetermined. Pioneer species in bold. 
Table 4. Kruskal-Wallis Sign by Ranks significance for fish assemblage attributes with PCB concentration for species composition, IBI metric score, and biomass.

\section{SPECIES COMPOSITION}

Total number of species (NUMSPP)

Number of DMS species (NUMDMS)

Number of darter species (NUMD)

Number of sunfish species (NUMSUN)

Number of sucker species (NUMSUC)

Number of sensitive species (NUMSEN)

Percent pioneer species (PERPIO)

Percent carnivore species (PERCARN)

\section{SIGNIFICANCE}
$P<0.0001$
$P<0.0001$
$P<0.0001$
$P<0.0001$
$P<0.0001$
$P<0.0001$
$P<0.0001$
$P<0.0001$

\section{BIOMASS}

Total biomass (BIOSPP)

Biomass of sunfish species (BIOSUN)

Percent biomass of sunfish species (PBIOSUN)

Percent biomass of minnow species (PBIOMIN)

Biomass of sucker species (BIOSUC)

Percent biomass of sucker species (PBIOSUC)

Biomass of sensitive species (BIOSEN)

Percent biomass of sensitive species (PBIOSEN)

Percent biomass of tolerant species (PBIOTOL)

Percent biomass of pioneer species (PBIOPIO)

Percent biomass of carnivore species (PBIOCARN)
$P<0.0001$
$P<0.0001$
$P=0.0003$
$P<0.0001$
$P<0.0001$
$P<0.0001$
$P<0.0001$
$P<0.0001$
$P<0.0001$
$P<0.0001$
$P<0.0001$

\section{IBI METRIC SCORE}

M- Percent headwater species (M-PERHW)

M- Number of minnow species (M-NUMMIN)

M- Number of sucker species (M-NUMSUC)

$\mathrm{M}$ - Percent pioneer species (M-PERPIO)

M- Percent carnivore species (M-PERCARN)

$$
\begin{aligned}
& P=0.032 \\
& P<0.0001 \\
& P=0.031 \\
& P=0.0003 \\
& P<0.0001
\end{aligned}
$$


Chapter 6 - PCBs and Natural Resource Injuries to Fish at the Westinghouse sites: Did We Succeed in Finding Causation?

\section{Introduction}

The Comprehensive Environmental Response, Compensation and Liability Act (CERCLA) 42 U.S.C. § 9601et seq. (1980) authorized the designation of "trustees" for natural resources by the President and State Governors. Trustees, including the Department of the Interior (DOI) and most natural resource agencies in every state, conduct natural resource damage assessments (NRDA) for the purpose of restoring and/or compensating the public for losses to natural resources that have resulted from the release of hazardous substances (Brighton 1994). The Comprehensive Environmental Response, Compensation and Liability Act also required DOI to develop the regulations for conducting NRDAs. For a synopsis of the NRDA regulatory process, see Chapter 1. According to Boehm and Ginn (2013) "the steps of the NRDA process are both scientifically rigorous (i.e. include hypothesis testing as inherent in the scientific methods) and generally specified in the several regulations that drive the NRDA." On the other hand, CERCLA is very litigious because "by its very nature of its complex intertwining of law, policy, and science, an evolving landscape" (Desjardins 2014). This current study will focus on the injury determination phase of the NRDA process. This phase often includes a literature review, field studies, laboratory studies, and/or injury assessments carried out in the context of potential litigation which often should include the development of sampling plans (SAP) and Quality Assurance project plans (QAPP) (Lee and Bridgen 2002). It is interesting that the authorizing law, CERCLA, did not define the term "injury" 
(Brighton 1994). The definition of injury comes from the NRDA regulations (that DOI promulgated in 1987) and states that injury is "a measurable adverse change, either longor short-term, in the chemical or physical quality or the viability of a natural resource resulting either directly or indirectly from exposure to a ... release of a hazardous substance, or exposure to a product of reactions resulting from the ... release of a hazardous substance" (43 CFR 11.14). Natural resource trustees must "determine whether an injury to natural resources has occurred and that the injury resulted from the release of a hazardous substance based upon the exposure pathway and the nature of the injury" [43 C.F.R. 11.61 (a)].

The criticisms of the DOI NRDA regulations [43 CFR 11] have come from all directions. On the one hand, "these far sighted legal provisions have not worked" (Olson 1989) to the other perspective "from NRDA's inception, state trustees, environmental scientists, and industry experts have criticized the DOI regulations" (Desjardins 2014; see also Barnthouse and Stahl 2002). Desjardins (2014) criticized the regulations because they allow trustees the flexibility to use any reliable, cost effective methodology that meets their basic requirements. Instead, Desjardins (2014) stated that the trustees should assess "ecosystem services", focusing on the whole ecosystem instead of looking at the pieces. Natural resource trustees have been accused of piecemeal assessment efforts concentrating on small areas of habitat or individual dead birds while failing "to consider the inherent worth or the value of the entire ecosystem" (Kornfeld 2011). Along these same lines, the original version of the DOI regulations at 43 CFR 11 were struck down in Ohio v. DOI precisely because the valuation of injured natural resources is so difficult to quantify (Kopp et al. 1990). The Court found that restoration was the congressional intent 
of CERCLA, almost certainly because they (Congress) doubted the "human ability to measure a resource's true value" (Kopp et al. 1990). More recently, Boehm and Ginn (2013) were highly critical of the DOI regulations' injury acceptance criteria [43 CFR 11.62(f)(2)] because trustees can conduct natural resource damage assessments that are poorly documented and anecdotal. Despite these strong criticisms, the DC Circuit Court upheld the CERCLA DOI regulations (43 CFR 11) in that the trustees must establish a causal link ("pathway") and need to show "a particular spill caused a particular injury" but that the "causation of injury standard" should be no less stringent than that in common law (Brighton 1994). Further court ruling state that the release of a hazardous substance should be a "contributing factor" (US v. AVX), and "substantial contributing factor" (Acushnet v. New Bedford Harbor...) in order to confirm causation (Brighton 1994). Unfortunately, according to the Harvard Law Review (2015), "causation can refer to many distinct concepts, due to different requirements in different doctrines" and "treatment of causation has been particularly inconsistent in environmental law cases."

Most scientists and many courts hold the methodology used in epidemiological studies to be the gold standard for linking exposure to allegedly toxic substances with harm (Boehm and Ginn 2013; Bandza 2012). Fox (1991) was the first to describe how the use of epidemiological criteria should be used in the field of ecotoxicology, just a few years after promulgation of 43 CFR 11. The seven epidemiological criteria Fox (1991) identified are probability, time order, strength of association, specificity, consistency on replication, predictive performance and coherence. These certainly do not conflict with the acceptance criteria [43 CFR 11.62(f)(2)] and effective natural resource trustees utilize this analysis in their injury assessments. Critics (Boehm and Ginn 2013) have suggested 
trustees use other methods to determine causation (EPA 1998; Suter et al. 2002; Suter et al. 2010) and although these approaches are helpful, these are not exclusive or in conflict with the acceptance criteria at [43 CFR 11.62(f)(2)].

The realm of scientists and the realm of litigation are very different and yet "both disciplines seek, in structured debate, using empirical evidence, to arrive at rational conclusions that transcend the prejudices and self-interest of individuals" (Goodstein 2000). However, the law and science treat facts differently (Bandza 2012). Analysis of these differences is fascinating and should be included as necessary curriculum for all NRDA practitioners (see Bandza 2012, Goldstein 2000, Federal Judicial Center 2011). Before evaluating the research that has been done at the Monroe County, Indiana Westinghouse sites as to whether or not injuries have occurred, discussion of a few related topics is necessary: peer review, complicated science in court, and rules governing the use of evidence in court as these relate to this injury assessment.

Peer review is prized in both the legal and scientific realms because it is a demonstration of the reliability of scientific evidence (Swinehart 2008). However in a courtroom situation, a peer reviewed report or publication may be considered misleading or even excluded as hearsay (Carlson 2013). While the specific methodology can be considered sound, it is uncertain whether or not the empirical data analyzed by peer reviewed methods even apply to the "individualized controversy" before the trier of fact (Judge) (Swinehart 2008). And there is the situation where "litigation generated science" can have the appearance of bias (Boden and Ozonoff 2008). Essentially, this is what sparked the Daubert v. Merrell Dow Pharmaceuticals, Inc. (509 US 579 - Supreme Court 1993) controversy (see below). 
Science can be extremely complex. For instance, the science behind cancer and carcinogens as evaluated by EPA sponsored animal cancer studies are neither reliable nor relevant and are therefore inadmissible in most courtrooms (Hungerford 2010). Regarding human toxicological studies, "there are few epidemiological or mechanistic studies of the toxic effects of many of these substances that are alleged to cause disease" (Childs 2002). Part of this debate is whether or not there is a threshold beyond which (on a dose response curve) cancer is inevitable (Hungerford 2010). Many toxicologists have begun to support the concept of a non-monotonic non-threshold (NMNT) or U-shaped dose-response curve for some toxic compounds (such as with "alleged" endocrine disrupting compounds); according to Surprenant and Surprenant (2013), this sort of evidence should never be admissible because this has not been sufficiently proven. The PCB-induced neuroendocrine disruption in fish has been well established in the peer reviewed literature (Chapter 3 ) but does not necessarily exhibit a classic dose response curve. So while scientists could conclude natural resource injury has occurred, it is questionable how a court might utilize it. Alternatively, it has been argued that incomplete science should not justify exclusion of evidence (Melnick 2005). But the bottom line at trial is to avoid unnecessary complexity and detail (Carlson 2013).

Prior to the U.S. Supreme Court "Daubert" decision, the "Frye" standard essentially stated that evidence could be used if it was "generally accepted" in the professional or scientific community (Schofield 1997). Daubert defined the trial judge's "gatekeeping" role on evidence admission "to ensure that any and all scientific evidence is not only relevant, but reliable" (Daubert v. Merrell Dow Pharmaceuticals, Inc. 509 US 579 - Supreme Court 1993). According to Pipoly (2012), Kumho Tire v. Carmichael clarified Daubert by adding 
"judges may formulate reliability criteria on a case by case basis that relied 'on the nature of the issue, the expert's particular expertise, and the subject of his testimony."'

What a scientist thinks is compelling cannot always be used in court. Under Daubert the ability to utilize scientific evidence is controlled by several Federal Rules of Evidence (FRE) (Williams 2003.) An interesting consequence of FRE is that scientific literature may be used extensively at pretrial hearings and rarely at trial (Carlson 2013). This seems illogical to the scientific-minded that citing literature at trial can get excluded as hearsay. The pretrial Daubert hearing is taking on increasing importance and is where all the science needs to be amassed (Carlson 2013).

The battle to admit or exclude evidence has continued both in the courtroom as well as in print. The primary argument for liberally admitting evidence under Daubert is that it forces courts to sort out matters of science that have yet to be completely settled (Mahle 2012). Testing by an adversarial process is valuable (Jurs and Devito 2013). This battle over science in American courtrooms has focused on the use of experts (Kuay 2012; Carlson 2013). Obviously, all litigants only use paid experts who support the position that they want them to (Allen and Nafisi 2010; Bernstein 2015). "Conscientious, respectable experts can come to different conclusions about scientific evidence without making obvious mistakes and without being charlatans. So that justice is done between parties, courts need to allow reasonable scientific disagreement to avoid excluding from trials respectable experts and all relevant scientific evidence" (Cranor 2005). On the other hand, Dillingham et al. (2003) prescribes a very narrow path to admitting general causation expert testimony in toxic tort cases: "epidemiological studies must be perfectly tailored to case specifics and replicated or otherwise inadmissible." Unfortunately it is 
quite unrealistic to have perfect, replicated epidemiological studies available in a timely fashion. Expert opinion takes judgment as well as objective facts (Bernstein 2015).

Evidence suggests that the side that prevails in litigation needs to be well funded, whether in civil or criminal court (Friedman et al. 2005). Civil court defendants usually win and criminal defendants virtually always lose their challenges to proffers of expert testimony (Risinger 2000). Expert testimony brought by the prosecution most often is allowed in criminal court. Plaintiffs in civil court proceedings have to face strong challenges to their experts (Risinger 2000). Generally speaking, civil defendants have deep pockets, while often criminal defendants do not.

Preparing to bring scientific evidence to court requires substantial effort because you will have opposition (Jawetz 1998). There is a staggering array of expert and technical services available to your opponent. A recent expert witness directory (Seak 2016 Expert Witness Directory, http://www.seakexperts.com/content/expertdirectory.pdf, accessed December 19, 2016) lists over 1,200 expert witnesses indexed by over 7,000 categories. There are many consultants that make frequent appearances in support of companies dealing with NRDA and PCB liabilities (D. Sparks, pers. observation). Industry has funded research and extensive public relations campaigns to assist with their causes (O'Boyle 1998; Neff and Goldman 2005). There is also published guidance on how to Daubert-proof your expert (Nichols and Nichols 2003). The medical community is also continually taking steps to address financial conflicts of interest when it comes to scientific inquiry involving drugs, treatments and medical devices (Alpert et al. 2002). No one is immune to potential conflict of interests and prone to self-interest (Alpert et al. 2002). 
Considering all these matters, it is not unexpected that neither Frye nor Daubert solve the corrupt expert problem (Kaufman 2001).

\section{Injury Assessment Evaluation}

In view of the previous discussion of litigation and science, now it must be determined whether or not "natural resource" "injuries" have occurred at the Westinghouse, Monroe County PCB-contaminated sites. Specifically, have PCBs, a "hazardous substance," had an adverse impact on the creek chub (Semotilus atromaculatus), a "biological resource." Several of the previously mentioned words are "terms of art" within the NRDA process. The entire suite of results from Chapters $1-5$ were compared against the 4 acceptance criteria for injury and most, but not all, of these assessment endpoints rise to the level of natural resource injury. It has been suggested that using "methods long accepted by fisheries biologists... using standardized approaches" is an appropriate way for conducting NRDA injury investigations (Boehm and Ginn 2013). Strengths and weaknesses of these scientific investigations are identified and suggestions to improve their chances of success in NRDA litigation are discussed.

\section{Chapter 1: Water and Fish Tissue PCB Concentrations}

In Chapter 1, we tabulate a brief summary of PCB concentrations in water and fish tissue at all the sites studied. Chapter 1, Table 1 represents thousands of water and sediment samples collected at these sites over decades. All of these water samples were collected by the U.S. Environmental Protection Agency (U.S. EPA) or the Potentially Responsible 
Parties (PRPS) under U.S. EPA oversight as part of a CERLCA or Resource

Conservation and Recovery Act (RCRA) 42 U.S.C. § 6901et seq. (1976) regulatory process. If water samples exceed the ambient water quality criteria (AWQC) of the Clean Water Act (CWA) (33 U.S.C. $\$ 1251$ et seq.) this is an injury to surface water under 43 CFR $11.62(b)(1)$.

There are essentially 3 injury criteria pertaining to PCBs in water. The PCB AWQC for the protection of freshwater aquatic life is $0.014 \mathrm{ug} / \mathrm{L}$ (14 parts per trillion) (U.S. EPA 2017). Additionally, Indiana has promulgated a PCB water quality criteria of $0.79 \mathrm{ng} / \mathrm{L}$ (0.79 parts per trillion) (327 Indiana Administrative Code 2-1-6). There are several published studies that calculate PCB water quality standards that would be protective of wildlife. Giesy et al. (1994) suggested a PCB water quality criteria of $1.0 \mathrm{pg} / \mathrm{L}$ (parts per quadrillion) that would be protective of bald eagles in the Great Lakes. Niimi (1996) stated that PCB water concentrations from $5-500 \mathrm{ng} / \mathrm{L}$ (parts per trillion) had a suspected source of local contamination.

Concentrations of PCBs emanating from the springs associated with Neal's Landfill, Bennett's Dump and Lemon Lane Landfill range in the single digits parts per billion (ppb), to as high as $700 \mathrm{ppb}$ from the Illinois Central Springs during storm events (Tetra Tech 2001). All of these are far in excess of the AWQC for PCBs, therefore it should be concluded that a surface water resource (a natural resource) was injured at these sites [43 C.F.R. 11.62 (b)(i)].

Although determining this category of injury is rather simple, there are significant additional steps needed to be taken to "quantify" surface water injury and then prepare to defend this line of argument in Court. It is likely that most of the PCB water quality data 
collected within the regulatory process is not in a form that is easily useful for the trustee agencies. Routine standard analytical methods used by regulatory agencies for the detection of PCBs in waters and effluents is only $0.1 \mathrm{ppb}$ (or 100 parts per trillion). This analytical ability is 1,000 to 100,000 times less sensitive than what is needed to be protective of wildlife, and does not allow trustees to easily determine the extent of surface water injury. So while there is evidence of PCB exposure to fish and wildlife many $\mathrm{km}$ downstream, accurately determining actionable PCB water concentrations further downstream is difficult due to sampling limitations (e.g. preservation, holding times) the hydrophobic nature of PCBs, temporal pattern of releases, and partitioning to sediment and air. EPA and trustees have been criticized for not collecting data suitable for use in both remedial decision making and injury assessment (Barnthouse and Stahl 2002) but because of the significant added expense and the higher burden of proof that the trustee agencies face, this is unlikely to change.

Natural resource injury to surface water caused by exceedances of PCB AWQC does not have any litigation case history to consider. It is also not clear whether the courts would give the AWQC the same gravitas that the agencies do. It is really interesting however that the science behind the establishment of the PCB AWQC was very solid, and has been established since 1980 (revised in 1986). In practice however, analytical chemistry efforts face many difficulties since it is not always an exact work product. The effort to manage the large amount of quality assurance (QA) / quality control (QC) documentation in support of analytical chemistry efforts would be overwhelming to courtroom proceedings. 
Chapter 1, Table 1 also represents many hundreds of fish tissue samples from the late 1970s through 2009. If fish tissue residues exceed the Food and Drug Administration's (FDA) tolerance levels established under $\S 402$ of the Food, Drug and Cosmetic Act (21 U.S.C. § 342 et seq.) in edible portions, or exceeds a State Fish Consumption Advisory standard then this an injury to biological resources under 43 CFR 11.62 (f)(1)(ii) and (iii). Certainly fish have bioaccumulated PCBs above FDA tolerance levels and Indiana Fish Consumption Advisory levels for more than $96 \mathrm{~km}$ of streams at and downstream of these PCB sites (IDEM 2004) so once again, it is reasonable to conclude that natural resource injury is occurring at these sites. Each year, Indiana publishes its Fish Consumption Advisory for Indiana streams which would be useful in future quantifying this natural resource injury for court.

\section{Chapter 2: Liver Enzymes and General Liver Health}

Chapter 2 confirms that liver enzyme oxidative stress and a general biomarker of liver health (lipidosis) were altered by PCBs. The literature is full of scientific works confirming that these biomarkers are induced to various degrees by PCBs (Wu et al. 2014; Liu et al. 2016). It is likely that this enzyme alteration as caused by PCBs would be acceptable to peer-reviewed scientific journals (thus meeting the "generally acceptable" criteria of the Frye standard of evidence admission). Hepatomegaly and potentially lipidosis would be considered injuries as per 43 CFR 11.62(f)(4)(vi) Physical Deformation (C) internal whole organ and soft tissue malformation. Although lipidosis has been repeated linked to PCB exposure in laboratory studies, it has also been the result of other causes, including but not limited to simple nutritional deficiencies or excesses. Therefore, this line of evidence 
would be a distraction rather than an asset in adding to the strength of the case that PCBs harm fish physiology. Presenting such information in court could easily fall along the lines of extraneous testimony that a Judge could sanction as a waste of time (FRE 403). Several of the critics say that biomarkers are important as indicators of potential injury, but do not actually count as injury (Boehm and Ginn 2013). Several researchers have found that various types of PCBs cause oxidative stress in reproductive organs (Kumar et al. 2004; Krishnamoorthy et al. 2007; Gao et al. 2013) and in areas of the brain associated with reproduction hormones (Lyng and Seegal 2008) which ultimately might lead to reproductive impairments. Therefore, confirmation of oxidative stress is a worthwhile line of evidence that adds strength to the assessment of other biological injuries.

\section{Chapter 3: Reproduction}

The NRDA regulations at 43 CFR11.62(f)(4)(iv) physiological malfunctions (E) state that reduced fish reproduction is an injury to natural resources. Even severe critics of the DOI regulations agree that reduced fish reproduction is indeed an injury (Barnthouse and Stahl 2002; Boehm and Ginn 2013). Through multiple lines of evidence this research effort confirmed creek chub reproduction was reduced in these PCB-contaminated streams. Documented adverse impacts included: altered sex steroids in females, reduced vitellogenin, reduced ovary maturation, delayed ovary maturation leading to atresia (and likely failed spawning and premature death), and delayed / altered male maturation. We have probability, time order, strength of association, specificity, consistency across the PCB gradient and numerous sites (i.e. consistency on replication), predictive performance 
and coherence indicative of causation. We have strong correlations to well proven studies.

Significant improvements could have been made to this reproduction injury assessment. The female sex steroid imbalance was statistically significant in a very simple test, even though our sample sizes were rather small $(n=43)$. The same is true regarding reductions in vitellogenin. Substantial remediation has occurred at most of these sites prior to the plasma sex steroid analysis (conducted in 2009). This indicates that these injuries can be found at current environmentally relevant concentrations, even a decade after remedial actions had begun. Time order considerations also suggest this injury was likely more severe during the decades that PCBs were discharged unabated so more timely samples would have strengthened this case.

Another weakness is that many of the adverse effects did not lend themselves well to statistical analyses. When comparing male secondary sex characteristics, it is clear that the PCB-stream males are not maturing as strongly or seasonally appropriately as the reference sites. These differences are visually very clear, however statistical significance is illusive. This is a spurious consideration and yet 43 CFR 11 and Daubert call for "statistical significance" and a "proven error rate", respectively. It is assumed, possibly incorrectly, that these are one in the same.

Reproductive impairment resulting from neuroendocrine disruption is a very complicated story that might be difficult to simply convey in court. Although we captured several neuroendocrine disruption endpoints, we did not document other indicators that were also likely impacted as well: luteinizing hormone (LH), maturation inducing hormone $(\mathrm{MIH})$, 11-ketotestosterone (11-KT), and serotonin $(5-\mathrm{HT})$. Measurement of some of these 
parameters could have strengthened this injury assessment. Given the resources available at the time (1992 - 2005), this would not have been possible.

The quantification of the degree to which reproductive injury was occurring from the 1960s to the present would be difficult. Given the documented adverse reproductive impacts, it is likely that if spawning was occurring in these PCB-contaminated streams, fertility, egg viability, larvae and fry survival could also have additive adverse outcomes due to PCBs. The trustees would have to counter the arguments that there are still fish in the stream, thus calling into question the significance of these documented injuries. Just as it seems logical to consider that delayed / altered male maturation is a form of reduced reproduction, it is uncertain whether or not a judge or jury would agree with the government on such complicated lines of evidence.

\section{Chapter 4: Age and Growth}

In this investigation, creek chub growth was altered and female survivorship was reduced thus qualifying as an injury to biological resources pursuant to 43 CFR 11.62(f)(4)(i) Death (B) fish kill investigations. Critics of the DOI regulations agree that reduced survival is indeed an injury (Barnthouse and Stahl 2002; Boehm and Ginn 2013). This should be considered an injury for two reasons. Although not specifically envisioned as a typical "fish kill", lack of survivorship is premature "death" which meets the injury criteria in the damage assessment regulations. And lack of survivorship reduces reproduction because older, bigger females spawn more eggs than younger, smaller creek chubs. This qualifies as an injury under 43 CFR11.62(f)(4)(iv) physiological malfunctions (E) reduced fish reproduction. Again, it is expected that this work will be published in a refereed journal, 
meeting the Frye standard. It is less certain that impaired growth would be considered an injury per se. Poor growth leads to poor survivorship; this is well known in the world of toxicologists and among fisheries professionals. The science of PCBs affecting growth has a long history in the established PCB toxicity literature, but it is complicated in field studies by potentially other factors. Creek chub growth is enhanced early in life by PCB exposure, followed by significant decline in growth after 24 months which is consistent with the poor survival we documented. The non-monotonic nature of the dose- (i.e. length of exposure) response curve (enhanced early, reduced later), although consistent with the literature, would be difficult to explain at trial. Whether or not this would prevail in a courtroom would be unknown. Critics of NRDA regulations state using commonly accepted fisheries methods (such as age and growth investigations) is an appropriate way for conducting NRDA injury investigation (Boehm and Ginn 2013). However, these authors say this in support of a poorly designed study that looked at a suite of very general fish health metrics on a grand scale in order to not find significant connections. It is doubtful that they would be as admiring of these results given their source of funding. It should be assumed that an adversary could find many ways to complicate the acceptance of this growth and survival injury assessment in court.

\section{Chapter 5: Fish Community Assessment}

The results of this analysis confirmed that the fish community was altered in PCBcontaminated streams. We found reduced predators, reduced growth and fitness across nearly all species of fish present. Given that creek chub reproduction was impaired (Chapter 3), and creek chub survivorship was reduced (Chapter 4), it was not unexpected 
that the entire fish community might also exhibit these same subtle impacts. Arguably these community impairments meet the injury criteria of death [43 CFR 11.62(f)(4)(i)(B)], albeit in an indirect manner. It could also be argued that these effects which meet all 4 of the DOI regulations acceptance criteria although PCB - fish community studies would be technically difficult to reproduce in the laboratory. While a regulatory risk assessment might consider this a strong line of evidence of adverse impacts, a fish community biodiversity injury investigation is perhaps too complicated to successfully explain in a courtroom. Although IBI is a common fisheries management technique that should have wide-spread support (Boehm and Ginn 2013), there is a strong possibility that this injury investigation would be excluded by a judge under FRE 403 .

\section{Conclusion}

A summary all of all the natural resource injury investigations conducted at 4 stream locations associated with the Westinghouse PCB sites is shown in this Chapter, Table 1. This effort has confirmed PCBs caused injury to fish in several ways at the Westinghouse study areas. The preponderance of laboratory toxicity evidence is that PCBs harm fish. However, it is clear that finding evidence of failing fish under field conditions is difficult (Barnthouse et al. 2003; Reiser et al. 2004; Maceina and Sammons 2013). Many of the best biomarkers such as plasma and neuroendocrine hormones are expensive and lethal. Large sample sizes are needed, further increasing the level of effort on determinations of age and fecundity. Meanwhile, most water and fish tissue analytical samples from the field exceed injury thresholds (AWQC and State Fish Consumption Advisories). Ideally, these thresholds should be considered established facts in court but specific supporting 
documentation is lacking. In addition, all the fish injury data collected from these PCBcontaminated streams is consistent with the original PCB toxicity studies that helped to establish the AWQC for PCBs in the first place. Consistency with the original PCB AWQC toxicity studies documenting harm further supports these injury determinations.

Unfortunately, confirming injury is not enough to bring a successful NRDA case. Quantification of injury and valuation of injury are big factors in the ultimate success of a NRDA. Much could be done to limit the usefulness of these injury determinations in court. All the fish are not dead so there may be fish that are at "best" impaired. It really is impossible to quantify stream carrying capacity for creek chubs in a simple, meaningful way that would be useful in court. It is also unclear how to assign a value on the fact that not every minnow in the stream can spawn successfully.

It would be difficult to convey the importance that these minnows are foundational to the food chain to a judge or jury of non-ecologists. What are the habitats that support creek chubs and their consumers worth? How long will it take for these habitats (or minnows) to recover? Monetizing this is even more difficult. It was argued successfully in Chapter 5 that not only the minnows were impacted, but the predator fish were as well. The Superfund program's risk assessments for the Westinghouse sites also confirmed risk to mink (Neovison vison), and fish-eating birds such as kingfisher (Chloroceryle americana) (Chapman 2005, 2006). These risks are based on the vast amount of ecological food web bioaccumulation PCB toxicity literature. These fish injury studies were also helpful to the U.S. EPA in establishing clean-up standards and pursuing costly remediation at these sites. However risk is not injury, so these risk assessments would likely be considered unnecessary data by the court in violation of FRE 403 . 
It is completely conceivable to win the injury portion of the case and still get nothing in the way of restoration / compensation. The courts have not been clear on what would be appropriate compensation because the true value of these resources is illusive (Kornfeld 2011). Nevertheless, natural resource trustees must persevere to generate the science that will assist the regulatory agencies in attaining adequate clean-ups that approach or excel AWQC. In addition, it is a worthy goal to use the NRDA regulations to confirm injury in the pursuit of restoration for injured resources and to seek compensation for past and residual injuries. In all probability, you will not fully succeed, but the AWQC criteria are based on well-established science and the NRDA program has worthwhile goals. And finally, settle on your way to court. Otherwise, the odds are you will get nothing. No one really wins in toxic tort litigation (Bandza 2012).

\section{References}

Allen RJ, Nafisi E (2010) Daubert and its discontents. Brooklyn Law Review 76:131-166

Alpert JS, Fumar S, Smaha L (2002) Conflicts of interest: science, money and health. Arch Intern Med 162:635-637

Bandza AJ (2012) Epidemiological-study reanalyses and Daubert: a modest proposal to level the playing field in toxic tort litigation. Ecology Law Quarterly 39:247-282

Barnthouse LW, Glaser D, Young J (2003) Effects of historic PCB exposures on the reproductive success of the Hudson River striped bass population. Environ Sci Technol $37: 223-228$ 
Barnthouse LW, Stahl RG (2002) Quantifying natural resource injuries and ecological service reductions: challenges and opportunities. Environmental Management 30:1-12

Bernstein DE (2015) What to do about federal agency science: some doubts about regulatory Daubert. George Mason Law Review 22(3):549-574

Boehm PD, Ginn TC (2013) The Science of Natural Resource Damage Assessments. Environ Claims J 25(3):185-225

Boden LI, Ozonoff D (2008) Litigation-generated science: why should we care? Environ Health Perspectives 116:117-122

Brighton WD (1994) Natural Resource Damage Assessment under CERCLA. In:

Burlington L, Roush Jr. WS (co-chairs) The new rules for Natural Resource Damage Assessments and Claims under CERCLA and OPA. Co-sponsored by the Section of Administrative Law and Regulatory Practice, American Bar Association and Prentice Hall Law \& Business

Carlson RL (2013) The curious case of differing literary emphases: the contrast between the use of scientific publications at pretrial Daubert hearings and at trial. Georgia Law Review 47:837-862 
Chapman J (2005) Focused ecological risk assessment PCBs and mammalian and avian piscivores in Conards Branch and Richland Creek: Neal's Landfill Site, Bloomington, Monroe County, Indiana. US. Environmental Protection Agency, Region 5, Chicago, IL

Chapman J (2006) Spatial trends in PCB accumulation in Clear Creek fish in 2002 and 2004, Lemon Lane Landfill Site, Bloomington, Monroe County, Indiana. US. Environmental Protection Agency, Region 5, Chicago, IL

Childs JC (2002) Toxicogenomics: new chapter in causation and exposure in toxic tort litigation. Defense Counsel Journal 2002(October):441-446

Cranor, C (2005) Scientific inferences in the laboratory and the law. American Journal of Public Health 95(S1):S121-S128

Desjardins M (2014) Ecosystem services: unifying economic efficiency and ecological stewardship via Natural Resouce Damage Assessments under CERCLA. George Mason Law Review 21(3):717-751

DeWitt J, Millsap DM, Yeager RL, Heise SS, Sparks DW, Henshel DS (2006) External heart deformities in passerine birds exposed to environmental mixtures of PCBs during development. Environ Toxicol Chem 25: 541-551

Dillingham WO, Hagan PJ, Salas RE (2003) Blueprint for general causation analysis in 
toxic tort litigation. FDCC Quarterly, 2003(Fall):21-36

Federal Judicial Center (2011) Reference manual on scientific evidence, 3rd ed. National Academies Press, Washington, DC

Friedman LC, Daynard RA, Banthin CN (2005) Learning from the tobacco industry about science and regulation. Am J Public Health 95(S1):S16-S20

Fox GA (1991) Practical causal inference for ecoepidemiologists. J Toxicol Environ Health 33:359-373

Gao M, Wu N, Song Y, Jin L, Lou J, Tao H (2013) PCB153-induced oxidative stress and cell apoptosis on cultured rat Sertoli cells. Toxicol Res 2013(2):173-179.

Giesy JP, Ludwig JP, Tillitt DE (1994) Dioxins, dibenzofurans, PCBs and colonial, fisheating water birds. In: Schecter A (ed) Dioxins and Health. Plenum Press, NY pp 249-307

Goldstein D (2000) How science works. In: Federal Judicial Center, Reference manual on scientific evidence, 2nd ed. National Academies Press, Washington, DC pp 67-82

Harvard Law Review (2015) Causation in environmental law: lessons from toxic torts. Harvard Law Review 128:2256-2277 
Henshel DS, Sparks DW (2006) Site-specific PCB-linked interspecies differences in organ somatic indices. Ecotoxicology 15:9-18

Hungerford A (2010) Back to basics: Courts' treatment of agency animal studies after Daubert. Columbia Law Review 110:70-110

Indiana Department of Environmental Management (IDEM) (2004) Angling Indiana - 2004 Fish Consumption Advisory. http://fn.cfs.purdue.edu Indianapolis, Indiana

Jawetz SM (1998) Trying to get to yes: legal and practical issues in NRDA negotiations In: International Business Communications, Natural Resource Damage Assessment: strategies for achieving beneficial outcomes for your company. April 29-30, 1998 Chicago, IL. IBC, Southborough, MA

Jurs AW, DeVito S (2013) Et tu, Plaintiffs? An empirical analysis of Daubert's effect on plaintiffs, and why gatekeeping standards matter (a lot). Arkansas Law Review 66:9751006

Kaufman HH (2001) The expert witness. Neither Frye nor Daubert solved the problem. What can be done? International review of law computers \& Technology 15(1):79-101

Kopp RJ, Portney PR, Smith VK (1990) Natural resource damages: the economics have shifted after Ohio v. United States Department of the Interior. Environmental Law 
Reporter 20:10127-10131

Kornfeld IE (2011) Of dead pelicans, turtles, and marshes: natural resources damages in the wake of the BP Deepwater Horizon spill. Environmental Affairs 38:317-342

Krishnamoorthy G, Venkataraman P, Arunkmar A, Vignesh RC, Aruldhas MM, Arunakaran J (2007) Ameliorative effect of vitamins ( $\alpha$-tocopherol and ascorbic acid) on PCB (Aroclor 1254) induced oxidative stress in rat epididymal sperm. Reprod Toxicol 23:239-245

Kuay C (2012) Ten years after Arkansas adopted Daubert: anything new under the sun? Arkansas Law Review 65:409-432

Kumar JS, Banudevi S, Sharmila M, Murugesan P, Srinivasan N, Balasubramanian K, Aruldhas MM, Arunakaran J (2004) Effects of vitamin C and E on PCB (Aroclor 1254) induced oxidative stress, androgen binding protein and lactate in rat Sertoli cells. Reprod Toxicol 19:201-208

Lee VA, Bridgen PJ (2002) The natural resource damage assessment deskbook: a legal and technical analysis. Environmental Law Institute, Washington, DC

Liu H, Nie FH, Lin HY, Ma Y, Ju XH, Chen JJ, Gooneratne R (2016) Developmental toxicity, oxidative stress, and related gene expression induced by dioxin-like PCB 126 in 
zebrafish (Danio rerio). Environ Toxicol 31:295-303

Lyng GD, Seegal RF (2008) Polychlorinated biphenyl-induced oxidative stress in organotypic co-cultures: experimental dopamine depletion prevents reductions in GABA. Neurotoxicology 29:301-308

Maceina MJ, Sammons SM (2013) Polychlorinated biphenyls in adult black bass and yellow perch were not associated with their reproductive success in the upper Hudson River, New York. Environ Toxicol Chem 32:1582-1591

Mahle SE (2012) The "Pure opinion" exception to the Florida Frye standard. Florida Law Journal 2012(February):41-45

Melnick RL (2005) A Daubert motion: A legal strategy to exclude essential scientific evidence in toxic tort litigation. Am J Public Health 95(S1):S30-S34

Neff RA, Goldman LR (2005) Regulatory parallels to Daubert: Stakeholder influence, "sound science," and the delayed adoption of health-protective standards. Am J Public Health 95(S1):S81-S91

Nichols JF Sr., Nichols JF Jr. (2003) Daubert proofing your expert. Am J Family Law 2003:108-112 
Niimi AJ (1996) PCBs in aquatic organisms. In: Beyer WN, Heinz GH, Redmon-Norwood AW (eds) Environmental contaminants in wildlife: interpreting tissue concentrations.

Lewis, Boca Raton, pp 117-163

O'Boyle TF (1998) At any cost: Jack Welch, General Electric, and the pursuit of profit. Knopf, New York

Olson ED (1989) Natural resource damages in the wake of Ohio and Colorado decisions: where do we go from here? Environ Law Reporter 19:10551-10557

Pipoly GM (2012) Daubert rises: the reapplicability of the Daubert factors to the scope of forensics testimony. Minnesota Law Review 96:1581-1605

Reiser DW, Greenberg ES, Helser TE, Branton M, Jenkins KD (2004) In situ reproduction, abundance, and growth of young-of-year exposed to polychlorinated biphenyls. Environ Toxicol Chem 23:1762-1773

Risinger DM (2000) Navigating expert reliability: are criminal standards of certainty being left on the dock? Albany Law Review 64:99-152

Schofield JR (1997) A misapplication of Daubert: Compton v Subaru of America opens the gate for unreliable and irrelevant testimony. Brigham Young University Law Review 1997(2):489-516 
Surprenant MC, Surprenant DC (2013) The emerging battlefield: should the use of a nonmonotonic, non-threshold dose-response curve for alleged endocrine-disrupting chemicals survive a Daubert/Frye challenge? Defense Counsel Journal 2013(January): $45-58$

Suter GW II, Norton SB, Cormier SM (2002) A methodology for inferring the causes of observed impairments in aquatic systems. Environ Toxicol Chem 21:1101-1111

Suter GW II, Norton SB, Cormier SM (2010) The science and philosophy of a method for assessing environmental causes. Human Ecol Risk Assess 16:19-34

Swinehart MW (2008) Remedying Daubert's inadequacy in evaluating the admissibility of scientific models used in Environmental-Tort litigation. Texas Law Rev 86:1281-1326

Tetra Tech (2001) Draft Current Status Report for Groundwater, Surface Water, Soil, Sediment and Fish Data: Lemon Lane Landfill Site, Monroe County, Indiana. Tetra Tech EM Inc, Chicago, IL

U.S. Environmental Protection Agency (U.S. EPA) (1998) Guidelines for ecological risk assessment. EPA/630/R-95/002F. Risk Assessment Forum. Washington, DC

U.S. EPA (2017) National Recommended Water Quality Criteria - Aquatic Life Criteria 
Table https://www.epa.gov/wqc/national-recommended-water-quality-criteria-aquatic-lifecriteria-table, accessed 1-1-2017

Williams ML (2003) The history of Daubert and its effect on toxic tort class action certification. The Review of Litigation 22(1):181-208

Wu F, Zheng Y, Gao J, Chen S, Wang Z (2014) Induction of oxidative stress and the transcription of genes related to apoptosis in rare minnow (Gobiocypris rarus) larvae with Aroclor 1254 exposure. Ecotoxicol Environ Safety 110:254-260 
Table 1. Types of Natural Resource injury evaluated and/or observed at the Westinghouse PCB sites, Monroe County, Indiana.

\begin{tabular}{|c|c|c|c|}
\hline Categories of Natural Resource Injury & $\begin{array}{l}\text { causative } \\
\text { agent }\end{array}$ & $\begin{array}{l}\text { animals } \\
\text { affected }\end{array}$ & documentation \\
\hline 43 CFR 11.62(b)(1) Surface Water & PCBs & water & Remedial Investigations, U.S. EPA \\
\hline $\begin{array}{l}43 \text { CFR 11.62(f)(1)(ii) \& (iii) Fish Consumption } \\
\text { Advisories }\end{array}$ & PCBs & fish & IDEM reports \\
\hline \multicolumn{4}{|l|}{43 CFR 11.62(f)(4)(i) - Death ${ }^{1}$} \\
\hline (B) fish kill investigations & PCB & fish & Chapter 4 \\
\hline (E) laboratory toxicity testing & PCBs & fish & literature \\
\hline 43 CFR 11.62(f)(4)(iv) - Physiological Malfunctions & & & $\begin{array}{l}\text { Chapter } 2 \text { physiological toxic response, } \\
\text { not an injury per se }\end{array}$ \\
\hline (B) reduced avian reproduction & PCBs & songbirds & U.S. FWS investigations \\
\hline (E) reduced fish reproduction & PCBs & fish & literature, Chapter 3, Chapter 4, Chapter 5 \\
\hline \multicolumn{4}{|l|}{43 CFR 11.62(f)(4)(vi) - Physical Deformation } \\
\hline (A) overt external malformations & $\begin{array}{l}\text { PCBs } \\
\text { PCBs }\end{array}$ & $\begin{array}{l}\text { songbirds } \\
\text { fish }\end{array}$ & U.S. FWS reports unpublished \\
\hline $\begin{array}{l}\text { (C ) internal whole organ and soft tissue } \\
\text { malformation }\end{array}$ & $\begin{array}{l}\text { PCBs } \\
\text { PCBs }\end{array}$ & $\begin{array}{l}\text { songbirds } \\
\text { fish }\end{array}$ & $\begin{array}{l}\text { DeWitt et al. 2006; Henshel \& Sparks 2006; } \\
\text { lipidosis Chapter } 2\end{array}$ \\
\hline
\end{tabular}

1 - using the acceptance criteria, death can also be confirmed by: a) absence in the impacted area, b) bioassays conducted in the laboratory, and/or c) comparisons to literature values. Chapter 4 describes the lack a female survivorship which is a form of mortality. 